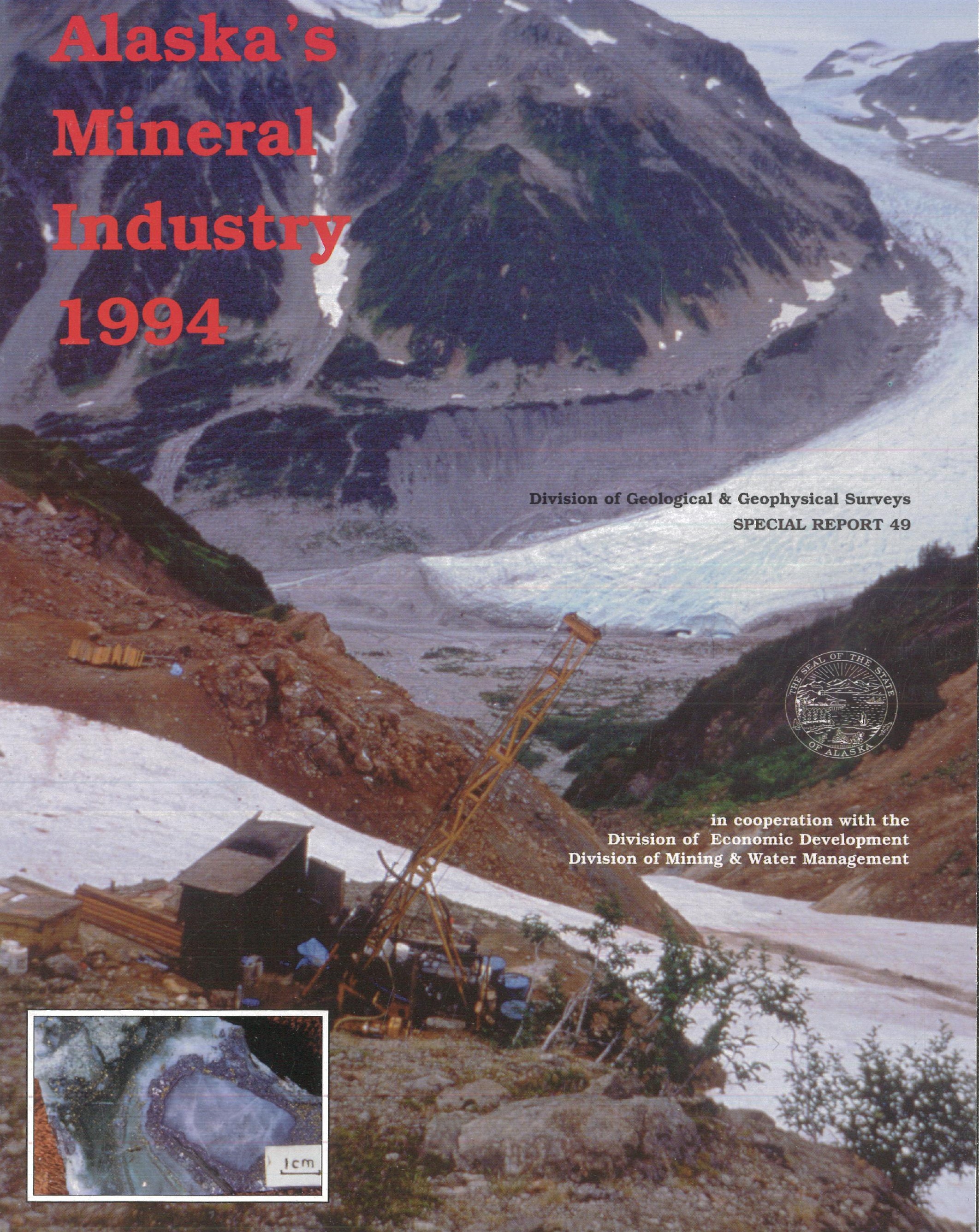


FRONT COVER: A diamond-drill crew explores the Johnson River gold-polymetallic deposit near Iliamna volcano about 200 miles (320 kilometers) southwest of Anchorage. The deposit, which was discovered by Anaconda Minerals in 1983, contains a current reserve of 1,097,583 tons (997,542 tonnes) grading 10.35 grams per tonnes gold, 7.84 grams per tonnes silver, $8.37 \%$ zinc, $1.17 \%$ lead, and $0.76 \%$ copper. If it is developed, the deposit will be mined by underground mining methods. The deposit is part of lands owned by Cook Inlet Region Inc. and is currently being explored by Westmin Resources Ltd.

Inset: Closeup of epigenetic (formed later than the enclosing rocks) textures in the quartz-sulfide stockwork of the Johnson River deposit. (Photos by Chris Rockingham, Westmin Resources Ltd.)

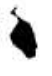

\section{BACK COVER}

Top left: A display of high-purity (about 900 fine) gold nuggets recovered from Silverado Mines Inc. openpit and underground placer gold mine operations on the Eureka and Mary's bench deposits in the Koyukuk-Nolan district of northern Alaska. The center nugget weighs 41.35 ounces (1,286 grams) and is unofficially the tenth largest nugget recovered from Alaska's placer districts. Note: The coin is a 50 cent piece, not a dime. (Photo by Tom Bundtzen)

Top right: The Valdez Creek placer gold mine, 50 miles (80 kilometers) east of Cantwell, has been Alaska's largest gold mine for ten of the last eleven years, and it is one of the largest placer gold operations in the world. In 1994 the mine, which has been operated by Cambior Alaska Inc., produced 47,622 ounces $(1,481$ kilograms) of gold. The photo shows pit A-9, the last of a series of moving pits. The mine is scheduled for closure in September 1995. (Photo by Tom Bundtzen)

Lower left: The Red Dog Mine complex in northwest Alaska shows the spatial relationship of the open cast mine (center), the mill and camp facility (foreground), and the tailings pond (left-center). The mine is owned by NANA Corporation and operated by Cominco Alaska Inc. Production of 658,000 tons (596,940 tonnes) zinc, lead, and bulk concentrate made Red Dog one of the world's largest producers of zinc in 1994. (Photo courtesy of Cominco Alaska Inc.)

Lower right: Jim Jones, Jim Bennett, and Wayne Dick operate a Diamec diamond drill in the Mystery decline of the Nixon Fork Mine about 34 miles (50 kilometers) northeast of McGrath in western Alaska. Nevada Consolidated Goldfields Inc. is developing the copper-gold deposit as an underground operation with daily capacity of 165 tons (150 tornes) of high grade ore. Production is scheduled to start in the fall of 1995. (Photo by Richard Flanders) 


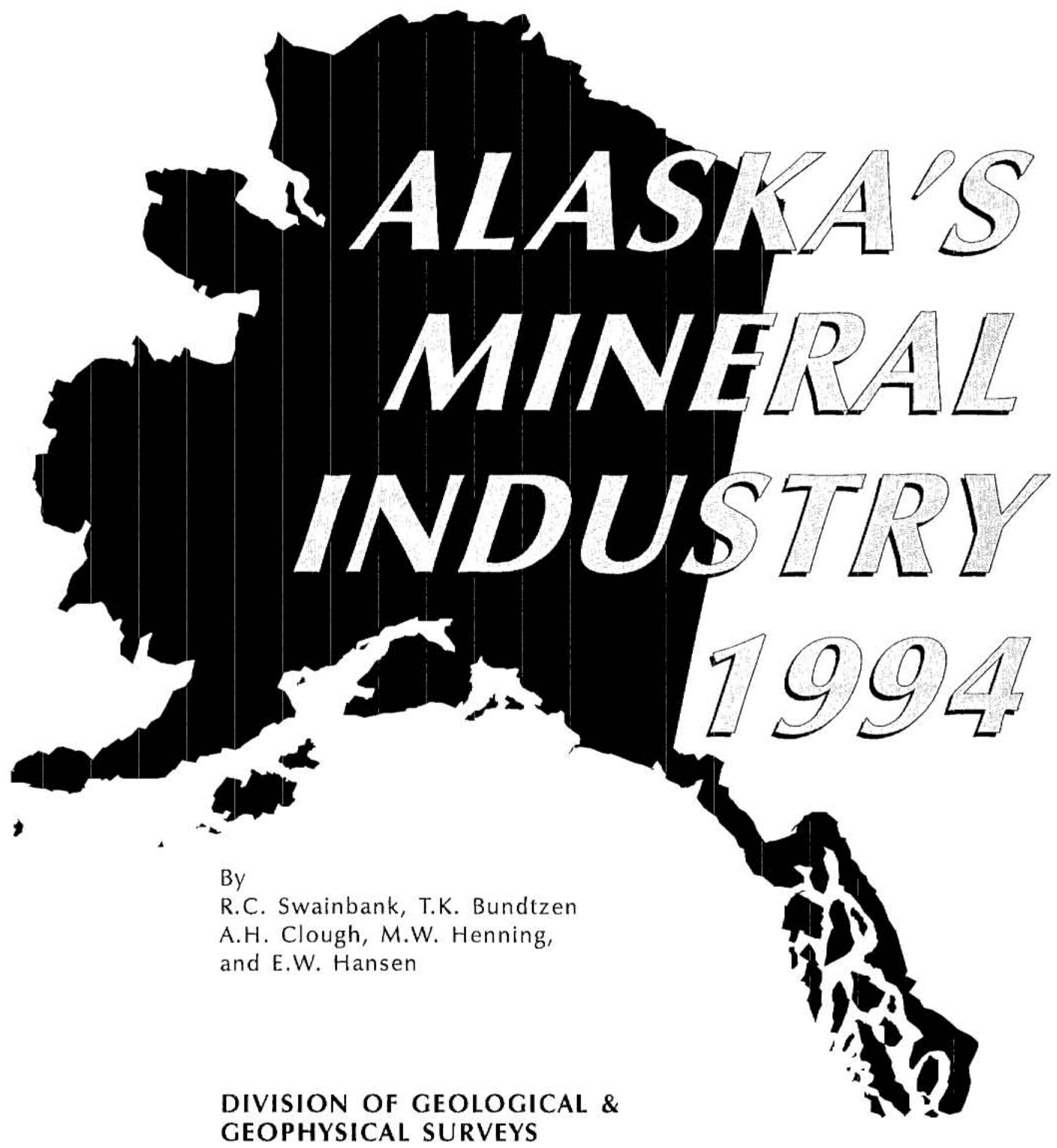

SPECIAL REPORT 49 


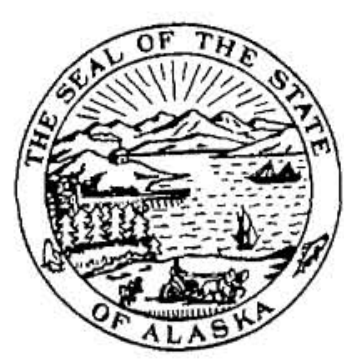

STATE OF ALASKA

Tony Knowles, Governor

\section{DEPARTMENT OF COMMERCE \& ECONOMIC DEVELOPMENT William L. Hensley, Commissioner}

DIVISION OF ECONOMIC DEVELOPMENT

Tom Lawson, Acting Director

DEPARTMENT OF NATURAL RESOURCES

John T. Shively, Commissioner

\section{DIVISION OF GEOLOGICAL \& GEOPHYSICAL SURVEYS}

Milton A. Wiltse, Acting State Geologist

\section{DIVISION OF MINING \& WATER MANAGEMENT Jules Tileston, Director}

DGGS publications may be inspected at the following locations. Address mail orders to the Fairbanks office.

\section{Alaska Division of Geological \\ \& Geophysical Surveys \\ ATTN: Publications}

794 University Avenue, Suite 200

Fairbanks, Alaska 99709-3645

Elmer E. Rasmuson Library

University of Alaska Fairbanks

Fairbanks, Alaska 99775-1005
University of Alaska Anchorage Library

3211 Providence Drive

Anchorage, Alaska 99508

Alaska Resource Library 222 W. 7th Avenue

Anchorage, Alaska 99513-7589

\footnotetext{
Alaska State Library

State Office Building, 8th Floor

333 Willoughby Avenue

Juneau, Alaska 99811-0571
}

Publication of this report is required by Alaska Statute 41 "to determine the potential of Alaska land for production of metals, minerals, fuels, and geothermal resources; the location and supplies of groundwater and construction materials; the potential geologic hazards to buildings, roads, bridges, and other installations and structures; and shall conduct such other surveys and investigations as will advance knowledge of the geology of Alaska."

NOTE: Mention of any company or brand name does not constitute endorsement by any branch or employee of the State of Alaska. 


\title{
CONTENTS
}

\author{
FOREWORD vii \\ EXECUTIVE SUMMARY 1 \\ Employment 1 \\ Exploration $\mathbf{2}$ \\ Development 2 \\ Production 3 \\ Government Action $\quad 3$ \\ Acknowledgments 3 \\ EXPLORATION 4 \\ Northern Region 4 \\ Metals 4 \\ Coal 4 \\ Western Region 5 \\ Metals $\mathbf{5}$ \\ Eastern Interior Region $\quad \mathbf{8}$ \\ Metals $\mathbf{8}$ \\ Industrial Minerals $\mathbf{1 0}$ \\ Diamond Exploration $\mathbf{1 0}$ \\ Southcentral Region 11 \\ Metals 11 \\ Industrial Minerals 11 \\ Southwestern Region 11 \\ Metals 11 \\ Alaska Peninsula Region 12 \\ Southeastern Region $\mathbf{1 2}$ \\ Metals $\mathbf{1 2}$ \\ Industrial Minerals

DEVELOPMENT 13

Northern Region 13

Metals 13

Coal 13

Western Region 14

Metals 15

Eastern Interior Region 15

Metals 15

Coal 17

Southcentral Region

Metals $\mathbf{1 7}$

Coal 17

Southwestern Region $\quad \mathbf{1 8}$

Metals 18

Southeastern Region $\quad 18$

Metals 18

\section{PRODUCTION 19}

Northern Region $\mathbf{2 4}$

Metals 24

Industrial Minerals $\mathbf{2 6}$

Coal $\mathbf{2 6}$

Western Region $\mathbf{2 6}$

Metals $\mathbf{2 6}$

Industrial minerals 


\section{CONTENTS}

Eastern Interior Region

28

Metals 28

Industrial Minerals $\quad \mathbf{3 0}$

Coal and Peat 30

Southcentral Region $\quad 31$

Metals $\mathbf{3 1}$

Industrial Minerals $\mathbf{3 2}$

Peat 33

Southwestern Region $\quad 33$

Metals $\mathbf{3 3}$

Industrial Minerals $\mathbf{3 4}$

Alaska Peninsula Region $\mathbf{3 4}$

Industrial Minerals $\mathbf{3 4}$

Southeastern Region $\quad \mathbf{3 4}$

Metals $\mathbf{3 4}$

Industrial Minerals $\mathbf{3 4}$

DRILLING 36

METAL AND MINERAL PRODUCT RECYCLING INDUSTRY

\section{GOVERNMENT ACTION 39}

\section{ALASKA MENTAL HEALTH LANDS SETTLEMENT 41}

\section{REFERENCES CITED 42}

\section{U.S. CUSTOMARY UNITS/METRIC UNITS CONVERSION CHART 77}

\section{APPENDIXES}

A. Total active and new claims staked in 1992, 1993, and $1994 \mathbf{4 3}$

B. Prospecting sites on state lands, $1994 \mathbf{4 5}$

C. State and federal agencies and private interest groups involved with mineral development activities 46

D. Selected significant mineral deposits in Alaska $\mathbf{5 2}$

E. Mining licenses issued by Alaska Department of Revenue $\mathbf{6 2}$

F. Primary metals production, 1880-1994 $\mathbf{7 2}$

G. Production of industrial minerals, coal, other commodities, 1880-1994 $\mathbf{7 4}$

\section{FIGURES}

1. Graph showing total value of Alaska's mineral industry in millions of dollars, 1981-94 1

2. Chart illustrating aspects of mineral industry employment, $1994 \quad 2$

3. Map showing selected exploration projects in Alaska, $1994 \quad 4$

4. Map showing regions of mineral activity in Alaska 3

5. Chart of exploration expenditures by commodity, $1994 \quad \mathbf{5}$

6. Photo of Nixon Fork Mining Company employee photographing diamond-drill core from the Nixon Fork gold-copper deposit 7

7. Photo of drill team exploring the True North gold deposit about 9 miles north of Fairbanks 9

8. Photo of Addwest Mineral Inc. exploring the Golden Zone copper-silver-gold deposit 11

9. Chart of development expenditures by commodity, $1994 \quad \mathbf{1 3}$

10. Map showing selected mineral development projects in Alaska, $1994 \quad \mathbf{1 5}$

11. Photo of Ed Armstrong of Silverado Mines Inc. inspecting a reclaimed mine area of Thompson's Pup 16 
12. Photo of Joy 12 CM-5 continuous miner outside entry of the Kuchiak Research Mine $\mathbf{1 6}$

13. Photo of F,S. Air Service of Anchorage unloading a Casa aircraft at the Nixon Fork 17

14. Photo of lower crosscut tunnel accessing a coal seam at the Evan Jones Mine $\mathbf{1 8}$

15. Graph of gold production in Alaska, 1880-1994 21

16. Graph of sand and gravel production in Alaska, 1950-94 21

17. Graph of coal production in Alaska, 1915-94 21

18. Map of selected production projects, $1994 \quad 22$

19. Photo of Alaska Gold Dredge Company's Dredge 6 at work on Submarine Bench, an ancient strandline west of the Nome airport $\mathbf{2 7}$

20. Photo of Robert Hehnlin at work mining placer gold on the Nome beachline $\mathbf{2 7}$

21. Photo of "fish wheels" designed to remove slide-rock from the slurry drain at Alaska Placer Development's Livengood operation 29

22. Photo of a cribbed shaft exposed when overburden was washed away $\mathbf{3 0}$

23. Photo of Roger Tallini operating a suction dredge on the South Fork of the Fortymile River

24. Photo of Cy Bras feeding a trommel-screen washing plant on Canyon Creek of the Fortymile district 31

25. Photo of Empire Exploration Inc. feeding a trommel-equipped washing plant with a backhoe at the Blue Ribbon Mine 33

26. Photo of Snow Lion Mining Company hydraulic winch system at work in the Porcupine district $\mathbf{3 5}$

27. Photo of Snow Lion Mining excavating with a 2-cubic-yard dragline bucket rigged to a stackline system 35

28. Photo of winter view of the Greens Creek polymetallic mine and mill facility on Admiralty Island 36

29. Photo of front-end loader stock-piling processed zinc concentrate at the Greens Creek Mine

30. Graph showing hard rock, placer, and coal drilling totals for $1994 \quad 37$

D-1. Map showing significant copper, lead, zinc with credits of silver, gold, and barite deposits in Alaska 53

D-2. Map showing significant molybdenum-copper and tin-tungsten with credits of fluorite and beryllium deposits in Alaska $\mathbf{5 4}$

D-3. Map showing significant gold, silver, platinum, and strategic mineral deposits in Alaska $\mathbf{5 5}$ Inside back cover. Mental Health Trust Lands map

\section{TABLES}

1. Total value of the mineral industry in Alaska by year 1

2. Alaska mine employment, $1990-94 \quad 2$

3. Reported exploration expenditures by commodity, 1982-94 6

4. Reported exploration expenditures and employment by commodity and region, $1994 \quad 6$

5. Summary of claim activity, $1989-94 \quad 7$

6. Reported mineral development expenditures by commodity, 1982-94 14

7. Reported mineral development expenditures and employment, $1994 \quad \mathbf{1 4}$

8. Estimated mineral production in Alaska, 1992-94 20

9. Reported refined gold production, number of operators, and industry employment, 1993-94

10. Production costs for selected Alaska placer gold mines, 1990-94 23

11. Reported sand and gravel production and industry employment by region, $1994 \quad \mathbf{2 4}$

12. Reported stone production and industry employment by region, $1994 \quad \mathbf{2 4}$

13. Cominco Alaska's Red Dog Mine production statistics, 1989-94 25

14. Production of refined ounces of gold from Valdez Creek Mine, 1984-94 32

15. Companies reporting significant drilling programs, $1994 \quad 37$

16. Drilling footage reported, 1986-94 37

17. Drilling footage by region, $1994 \quad 38$

18. Reported scrap metal and mineral-based recyclable products exported from Alaska, 1992-94

19. Revenues paid to the State of Alaska by Alaska's mineral industry, 1991-94 40 


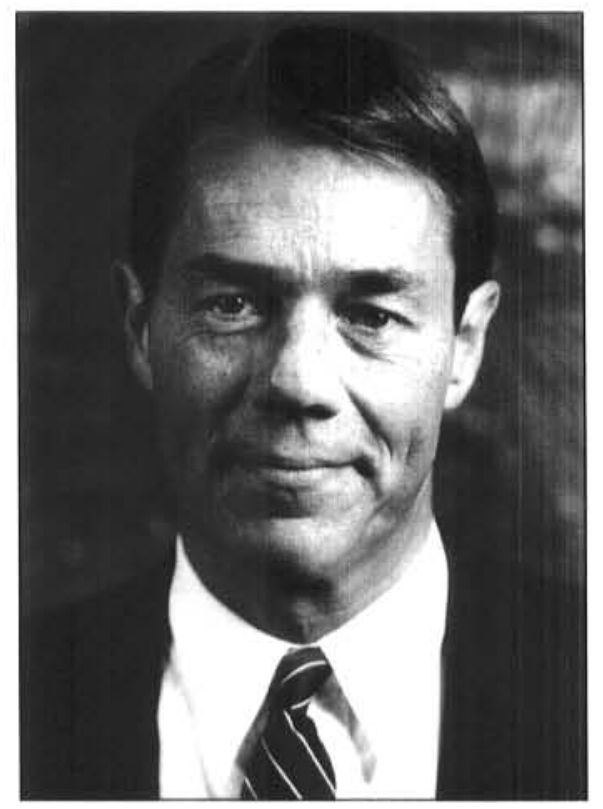

Alaska is open and ready to do business with the mineral industry. Partnerships with this growing segment of our economy are vital to the state's financial stability in the 21 st century.

As described in detail in this report, there was an upswing in the value of mineral production in Alaska in 1994. Production increased 13 percent over the previous year, and mineral development increased more than 62 percent.

Development of the Fort Knox Mine near Fairbanks, the Healy Clean Coal Project, Nixon Fork Mine near McGrath, Illinois Creek near Nulato, and the Greens Creek and Kensington mines near Juneau signal a bright future for mineral resources.

State-of-the-art airborne geophysical surveys sponsored by the State in 1993 at Nome, Circle, Nyac, and Valdez Creek resulted in increased exploration activity in 1994. Surveys of the Fairbanks and Richardson mining district in 1994 helped create a claim-staking rush that should result in increased private industry investment.

Recent legislation recognizes mineral exploration as a high-risk venture. It requires stability in land status, and it also requires some incentives. In June 1995, I signed HB 197, a mining incentive bill providing 100 percent credit for exploration costs against future mining license tax, corporate taxes, and royalties on production. This is just one way we are showing the mining industry that Alaska is willing to be a good partner, to share some of the risks and rewards of development in our state.

I look forward to seeing results from this new frontier of private/public partnership with the minerals industry.
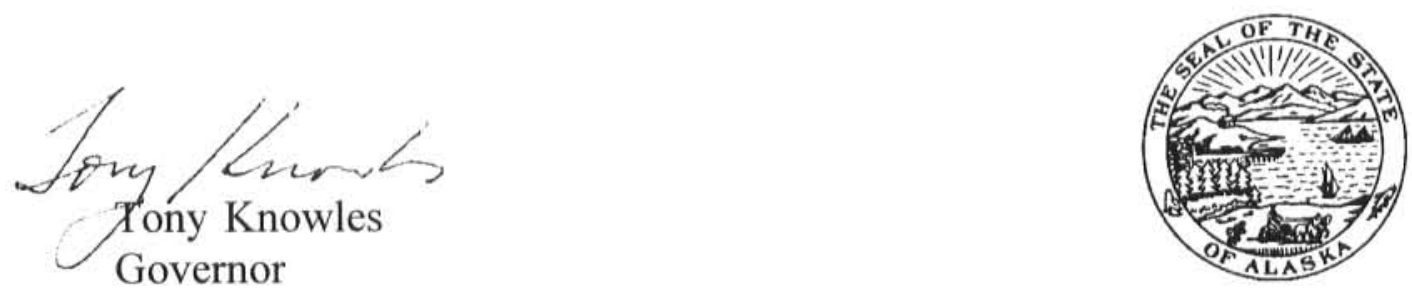
Alaska's Mineral Industry 1994, DGGS Special Report 49, is the 14th in the series of annual mineral reports prepared jointly by the Department of Commerce and Economic Development and the Department of Natural Resources. The primary objective of the report is to provide accurate information about Alaska's mineral industry activity during the calendar year. The information is provided voluntarily by private industry, Native corporations, individuals, and agencies.

The value of mineral production during 1994 was $\$ 507.5$ million, up 13.1 percent from the $\$ 448.7$ million in 1993. Mineral development investment increased to $\$ 44.94$ million in 1994 from \$27.7 million in 1993, and exploration expenditures of $\$ 31.1$ million were slightly higher than in 1993.

During the 1994 calendar year, there were many signs of a rebound of the industry. The Red Dog Mine in northwest Alaska shipped a record amount of polymetallic concentrate. In the last half of the year the mine operated at a profit after extensive improvements in the processing facilities. At the Greens Creek Mine near Juneau, work continued to define a new orebody, and the mine might reopen in late 1996 or early 1997.

The number of placer gold mines and the amount of gold produced continued to decline, but the value of the gold produced in 1994 was about the same as a result of increased bullion prices. Sand, gravel, and stone production, valued at $\$ 68$ million, was about the same in 1994 as in the previous year.

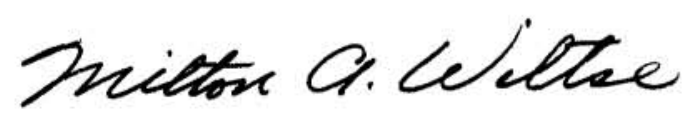

Milton A. Wiltse, Acting State Geologist Division of Geological \& Geophysical Surveys
Government agencies issued permits for the Fort Knox Mine and for the Healy Clean Coal Project in the eastern interior. Drilling at the True North gold property north of Fairbanks tripled the previous reserve estimates. In southeastern Alaska, the Alaska-Juneau and Kensington Mines have still not received their permits, and the issues of water quality and submarine tailings' disposal continue to be debated. The Nixon Fork Mine near McGrath and the Illinois Creek property near Nulato made progress towards development.

The Usibelli Coal Mine near Healy produced 1.49 million tons ( 1.35 million tonnes) and shipped about half of that to Korea. At the end of the year Usibelli concluded a new contract with the Korean Electric Power Company and Suneel Shipping Company, which will assure the export of coal for 1995.

The State of Alaska, through the Division of Geological \& Geophysical Surveys, contracted for airborne magnetic and electromagnetic surveys of the Fairbanks and Richardson mining districts in 1994. Partly in anticipation of the results, hundreds of new mining claims and prospecting sites were staked in the Fairbanks district during the 1994-95 winter.

The state presented the first Reclamation of the Year Awards. The state will present annual awards for exemplary work in returning disturbed ground to useful condition as required by state law.

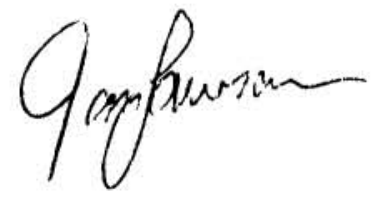

Tom Lawson, Acting Director

Division of Economic Development

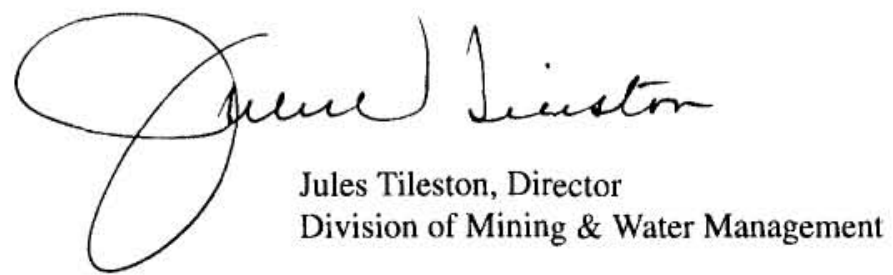




\section{Alaska's Mineral Industry}

1994

R.C. Swainbank, ${ }^{1}$ T.K. Bundtzen, ${ }^{2}$ A.H. Clough, ${ }^{3}$ M.W. Henning, ${ }^{4}$ and E.W. Hansen ${ }^{5}$

\section{EXECUTIVE SUMMARY}

This report is a cooperative venture between the Department of Natural Resources and the Department of Commerce and Economic Development. It gives an overview of the minerals industry during the calendar year 1994.

Most of the information contained in the report is provided by the responses to questionnaires mailed by the Division of Geological \& Geophysical Surveys to mining companies, Native corporations, consultants, metal recycling companies, and government agencies.

Table 1 shows the expenditures for exploration, development, and the value of production for the last fourteen years. The sum of these phases of mineral activity was $\$ 583.5$ million in 1994 , up 15 percent from the previous year (fig. 1). The value of preproduction mineral investment, or the sum of exploration and development, was $\$ 75.24$ million, 31 percent greater than in 1993.
Table 1. Total value of the mineral industry in Alaska by year (in millions of dollars)

\begin{tabular}{lrrrr}
\hline & Exploration & Development & & \\
& & & & \\
1981 & $\$ 76.0$ & $\$ 26.4$ & $\$ 188.6$ & $\mathbf{\$ 2 9 1 . 0}$ \\
1982 & 45.0 & 41.6 & 196.4 & $\mathbf{2 8 3 . 0}$ \\
1983 & 34.1 & 27.8 & 232.4 & $\mathbf{2 9 4 . 3}$ \\
1984 & 22.8 & 53.6 & 199.4 & $\mathbf{2 7 5 . 8}$ \\
1985 & 9.2 & 34.1 & 226.6 & $\mathbf{2 6 9 . 9}$ \\
1986 & 8.9 & 24.3 & 198.5 & $\mathbf{2 3 1 . 7}$ \\
1987 & 15.7 & 100.3 & 202.4 & $\mathbf{3 1 8 . 4}$ \\
1988 & 45.5 & 275.0 & 232.2 & $\mathbf{5 5 2 . 7}$ \\
1989 & 47.8 & 134.3 & 277.0 & $\mathbf{4 5 9 . 1}$ \\
1990 & 63.3 & 14.3 & 533.0 & $\mathbf{6 1 0 . 6}$ \\
1991 & 39.9 & 25.6 & 546.5 & $\mathbf{6 1 2 . 0}$ \\
1992 & 30.2 & 30.0 & 560.8 & $\mathbf{6 2 1 . 0}$ \\
1993 & 30.3 & 27.7 & 448.7 & $\mathbf{5 0 6 . 7}$ \\
1994 & 31.1 & 44.9 & 507.5 & $\mathbf{5 8 3 . 5}$ \\
Total & $\$ 499.8$ & $\$ 859.9$ & $\$ 4,550.0$ & $\$ \mathbf{5 5 9 0 9 . 7}$ \\
\hline
\end{tabular}

SoURCE: Alaska's mineral industry reports published annually by DGGS.

\section{EMPLOYMENT}

In 1994 the mineral industry provided 3,083 full-time-equivalent jobs, down from the 3,136 jobs in 1993 , (table 2; fig. 2).

Although there was a decrease in the number of people employed in the placer industry and in polymetallic mines, this decrease was balanced by the increased employment in exploration, development and in the sand and gravel sector. Employment in mineral

${ }^{1}$ Alaska Division of Economic Development, 751 Richardson Highway, Suite 205, Fairbanks, AK 99701.

${ }^{2}$ Alaska Division of Geological \& Geophysical Surveys, 794 University Ave., Suite 200, Fairbanks, AK 99709-3645.

${ }^{3}$ Alaska Division of Economic Development, 9th Floor, State Office Bldg., Juneau, AK 99811.

${ }^{4}$ Alaska Division of Mining \& Water Management, 3601 C Street, Anchorage, AK 99503.

${ }^{5}$ Alaska Division of Mining \& Water Management, 3700 Airport Way, Fairbanks, AK 99709.

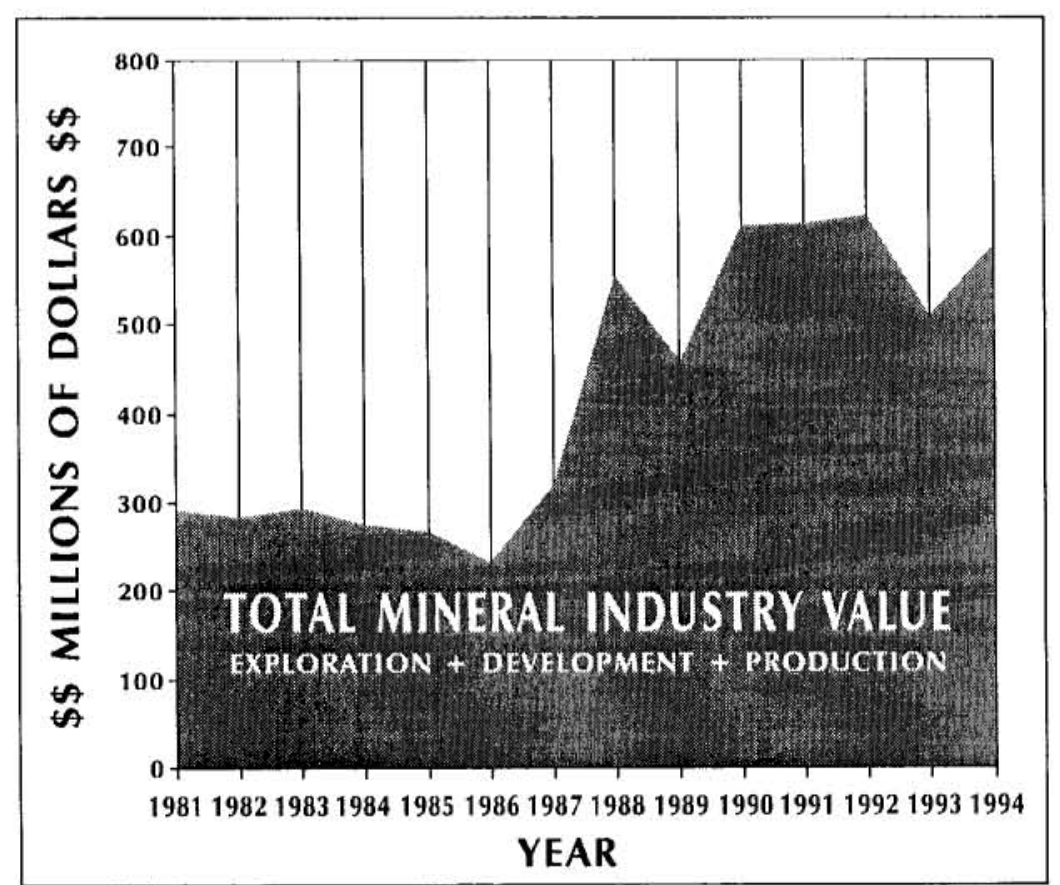

Figure 1. Total value of Alaska's mineral industry in millions of dollars, 1981-94. 
development is expected to rise in 1995 as the Fort Knox and Nixon Fork hard rock gold mines move toward production, and with the building of the Healy Clean Coal Plant.

\section{EXPLORATION}

Exploration expenditures in 1994 were reported as \$31.1 million, up slightly from \$30.3 million in 1993 . Figure 3 shows the regions of the state as described in this report. Although more exploration expenditures were reported in the southeastern region of Alaska in 1994 than in any other area, there were more programs and a higher level of activity in the eastern interior and western regions. Most of the southeast work was underground at the Alaska-Juneau and Greens Creek Mines. Except for the underground work at the Nixon Fork Mine near McGrath, exploration in the rest of the state was carried out from the surface. The Fairbanks area was particularly active. Successful exploration at the True North deposit, the final permitting of the Fort Knox Mine, and anticipation of the release of information from the DGGS airborne geophysical survey that was flown in 1994 prompted the filing of many new claims and prospecting sites.

Activity was reported at the Illinois Creek deposit in western Alaska, at Nolan Creek in northern Alaska, at Vinasale Mountain near McGrath, near Rampart on the Yukon, at the Golden Zone Mine near Cantwell, in the Nome area, and in the Ambler mineral belt.

Several of the major companies that have been active for several years and reported exploration programs throughout the state are Kennecott Exploration, Cominco Alaska Exploration, Amax Gold Exploration, American Copper \&

Figure 2. Mineral industry employment by category, 1994.

N/A-Not available.
Nickel and W.G.M. Newcomers doing exploration in Alaska are Addwest Minerals, Apollo Resources, and USMX. After a brief absence, Placer Dome U.S. and Newmont Mining have returned to Alaska.

After several years of relative quiescence, exploration for coal showed a resurgence in 1994 with the greatest activity in the northwest Alaska coal fields.

\section{DEVELOPMENT}

Mineral development expenditures in 1994 were $\$ 44.94$ million, compared with $\$ 27.67$ million reported the previous year (table 1).

Major projects were reported at the Red Dog zinclead-silver mine, at the Kuchiak coal mine, and at the

\begin{tabular}{|c|c|c|c|c|c|}
\hline & 1990 & 1991 & 1992 & 1993 & 1994 \\
\hline \multicolumn{6}{|l|}{ Gold/silver/mining } \\
\hline Placer & 1,151 & 1,240 & 1,251 & 1,205 & 1,150 \\
\hline Lode & N/A & N/A & N/A & N/A & -. \\
\hline Polymetallic & $265^{b}$ & $235^{\mathrm{b}}$ & $240^{b}$ & 26 & -. \\
\hline Base metals & 350 & 331 & 349 & 376 & 311 \\
\hline Recreational & 315 & 320 & 325 & 270 & 280 \\
\hline Sand \& gravel & 645 & 685 & 640 & 580 & 640 \\
\hline Building stone & 160 & 165 & 145 & 205 & 210 \\
\hline Coal & 115 & 115 & 115 & 109 & 115 \\
\hline Peat & N/A & 45 & 40 & 49 & 55 \\
\hline \multicolumn{6}{|l|}{ Tin, jade, soap-stone, } \\
\hline ceramics, platinum & 40 & 25 & 20 & 20 & 25 \\
\hline Mineral development & 95 & 133 & 164 & 132 & 115 \\
\hline Mineral exploration & 374 & 268 & 137 & 164 & 182 \\
\hline TOTAL & 3,510 & 3,562 & 3,426 & 3,136 & 3,083 \\
\hline
\end{tabular}

${ }^{a}$ Calculated on a 260-day work year.

${ }^{\text {b}}$ Revised estimate based on new company data.
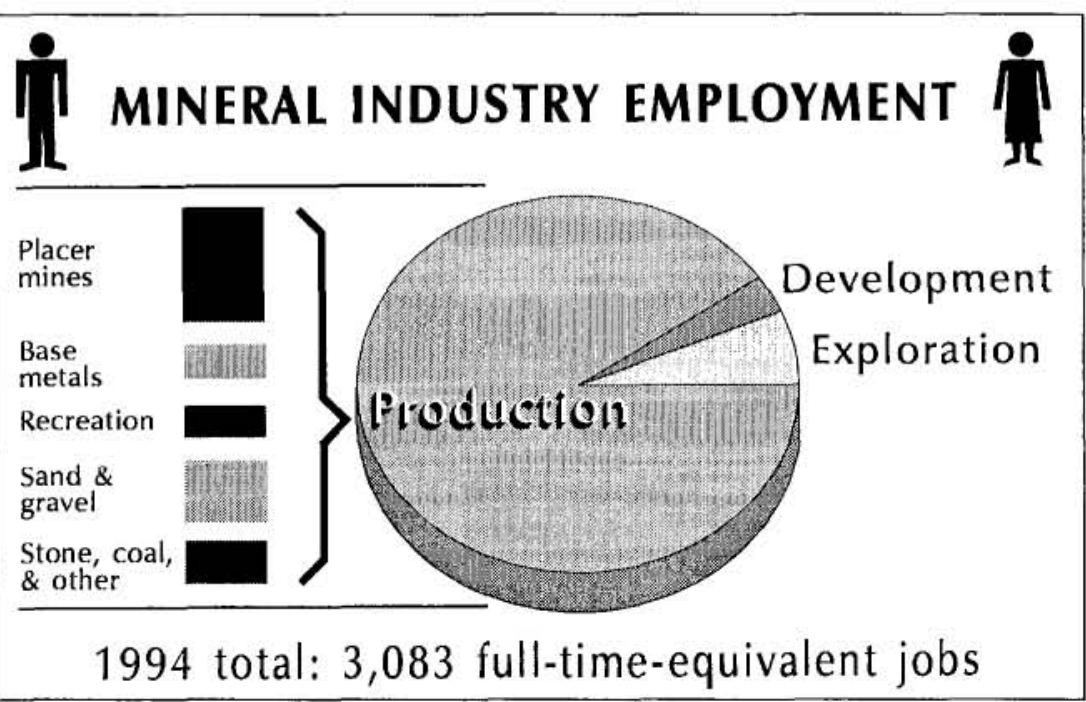
Nolan gold placer mine in the northern region; at the Nixon Fork high-grade gold mine near McGrath, at Illinois Creek, and at Nome in the western region; at the Fort Knox bulk-mineable gold mine and the Eldorado Creek underground placer in the eastern interior region; and at the Kensington and A-J hard-rock gold mines and the Greens Creek underground polymetallic mine in the southeastern region.

We anticipate that the 1995 expenditures will be much greater as the Fort Knox Mine, the Healy Clean Coal Project, the Greens Creek reopening, and several other projects go into high gear.

\section{PRODUCTION}

The value of production of all mineral commodities rose from $\$ 448.7$ million in 1993 to $\$ 507.5$ million in 1994 (table 1). This is almost entirely the result of increased production at the Red Dog zinc-lead-silver mine near Kotzebue in northwest Alaska.

Although production of gold was less in 1994 than in 1993, rising prices resulted in a slight increase in the value of production. The 26 percent increase in the price of silver in 1994 could not compensate for the production decrease due to the closure of the Greens Creek Mine, so the 1994 value of silver production was $\$ 14$ million less than in 1993.

The value of zinc production rose from $\$ 236$ million in 1993 to $\$ 296$ million in 1994 , and the value of lead production increased from $\$ 13.7$ million to $\$ 25.5$ million in the same period. All of this production came from the Red Dog Mine, and the owners reported that in the last half of the year the mine showed a profit for the first time.

The amount and value of industrial minerals and coal remained about the same in 1994 as in 1993.

\section{GOVERNMENT ACTION}

The most significant government actions in 1994 concerned permitting of the Fort Knox deposit and the Healy Clean Coal Project, and an interim solution to the long-standing Mental Health Lands dispute. The State of Alaska also completed the final selections of its Statehood Act land entitlements during 1994.

During 1994 two bills affecting the mining industry were signed into law. One has the effect of extending the terms of permits for the extraction of resources if the holder or issuing agency is prevented from using the permit due to litigation. The second was a technical amendment to the Alaska Lands Act to define the term "state selected land" for the purpose of recognizing mining locations on such lands.

The legislature continued to fund research to document trails which may be asserted as rights-of-way under the Revised Statute 2477 of the 1866 Mining Law, and provided funding to continue airborne geophysical surveys.

The number of federal mining claims was further reduced in Alaska, and only 8,495 federal claims remain active, compared with 20,254 as recently as 1992 . The number of active state claims decreased to 22,601 in 1994 from 25,684 in 1993.

\section{ACKNOWLEDGMENTS}

This report is designed, produced, and distributed by the Division of Geological \& Geophysical Surveys (DGGS) and the Division of Mining \& Water Management (DMWM) in the Department of Natural Resources, and The Division of Economic Development (DED) in the Department of Commerce and Economic Development. The current Alaska's Mineral Industry Report is published in the DGGS Special Report series, and is available from the three participating agencies.

In November 1994 Tom Bundtzen and Joni

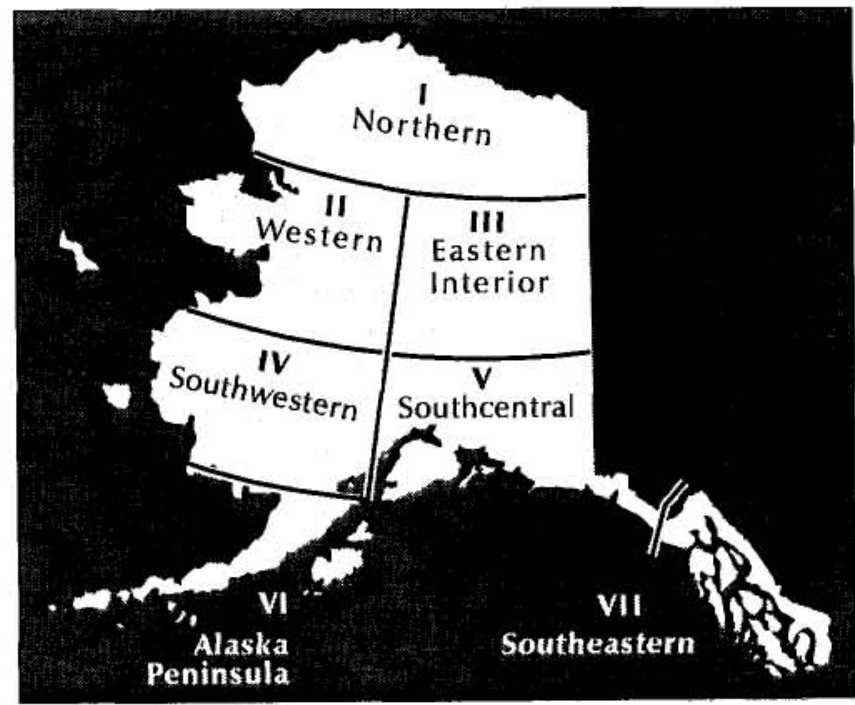

Robinson of DGGS mailed approximately 950 questionnaires to mineral exploration companies, Native corporations, mine operators, and government agencies that oversee or regulate mining activity. A total of 196 questionnaires was completed and returned to DGGS. We sincerely thank all of the respondents, without whom this report would not be possible.

Figure 3. Regions of mineral activity in Alaska as described in this report. 
Dick Swainbank wrote the Introduction, Exploration, Development, Drilling, and Government Action sections with the help of $\mathrm{Al}$ Clough and the other authors, and updated Appendix D. Tom Bundtzen wrote the Production and Metal Recycling sections, co-authored the Executive Summary, and updated Appendixes F and G. Erik Hansen updated Appendixes A and B, and Joni Robinson updated
Appendix C. Mitch Henning and Tom Bundtzen contributed the special report on the interim Mental Health Land Settlement that was ratified by the courts and legislature.

The production team consisted of Ann-Lillian Schell for the cover design, Greg Laird for the computer graphics, Fran Tannian for editing, and Joni Robinson for publication design and desktop publishing.

\section{EXPLORATION}

The reported amount spent on exploration in 1994 was $\$ 31.1$ million, a modest increase over the $\$ 30.3$ million reported in 1993. This figure is based on the responses by 74 companies that were received by May 1995 to questionnaires mailed by the State Division of Geological \& Geophysical Surveys. Figure 4 illustrates 1994 exploration expenditures by commodity. Figure 5 shows the locations of selected exploration programs throughout the state in 1994.

Table 3 compares the 1994 expenditures with those of previous years, and table 4 shows the expenditures by region and deposit type. Table 5 shows the number of claims staked and active throughout the state. The number of federal claims decreased about 60 percent between 1992 and 1994 which may reflect the new federal claim rental fee instituted in late 1992. The rental fee for many state mining claims doubled in 1994 from $\$ 20$ per 40 -acre (16-hectare) claim to $\$ 40$ per claim, which might explain the decrease in the number of active state claims between 1993 and 1994.

\section{NORTHERN REGION}

Reported exploration expenditures in the northern region in 1994 were $\$ 4.04$ million, more than double the $\$ 1.52$ million reported the previous year.

\section{Metals}

The Ambler mineral belt was a site of renewed interest in 1994. This area on the south slope of the westcentral Brooks Range contains the Bornite, Arctic, Sun,

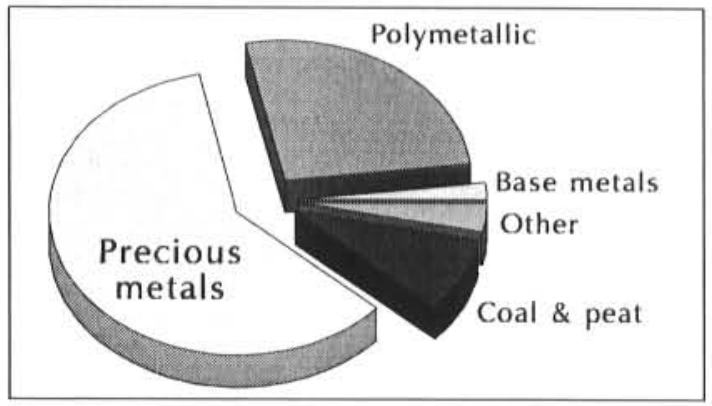

Figure 4. Exploration expenditures by commodity, 1994.
Smucker, Omar, and Frost volcanogenic massive sulfide deposits. Teck Exploration Company was the most active, and staked 160 mining claims. Kennecott Exploration, NANA Regional Corporation, and Cominco Alaska Exploration also had exploration crews in the Brooks Range.

Further east, on Nolan Creek near Wiseman, Silverado Mines (U.S.) Inc. continued placer exploration and reported that gold had been found associated with antimony mineralization along a 3-mile (5-kilometer) trend on the property. Some of the gold recovered from the placer mining was very fragile and enclosed within quartzite wall rock, indicating minimal transport. Silverado plans to further explore this mineralized zone in 1995. Lloyd Swenson performed minor exploration at his placer mine on Slate Creek near Wiseman.

In the fall, in the vicinity of Chandalar Lake, Hamlyn Estates staked a large block of hardrock claims. Del Ackels of Gold Dust Mines churn drilled on Big Creek during the summer.

\section{COAL}

Much of the coal exploration in the Northern Region was at the Kuchiak Coal Mine, 120 miles (193 kilometers) north of Kotzebue. Arctic Slope Consulting Group, working with Hobbs Industries and the U.S. Bureau of Mines, started development of a demonstration underground mine. This small underground mine, accessed through two portals, is about 1 mile (1.6 kilometers) from the site of a proposed large-scale mine. One entry is supported with conventional roof bolts and the other with resin-anchored bolts. A continuous miner was used to extract the coal. Many of the expected problems due to mining in permafrost-such as frozen water lines and goggles-were dealt with successfully.

Under a $\$ 600,000$ matching grant administered by the U.S. Bureau of Mines, a number of other studies were undertaken relating to reclamation of a nearby site, social and environmental impacts, hydrology and blasting methods. A contract has been let to Canarctic Shipping Company Ltd. to assess the feasibility of shipping coal from the northwest arctic to market. This company has accumulated extensive experience shipping to and from mines in the Canadian high arctic, much further north than Barrow. 


\section{WESTERN REGION}

Over $\$ 6.5$ million was spent on exploration in the western region in 1994, almost double the $\$ 3.4$ million of the previous year. Most of the activity was for hard-rock gold, but polymetallic targets were sought in the Nome area. In February 1994 the results were released of the 1993 magnetic and electromagnetic surveys of about 400 square miles (1,036 square kilometers) around Nome as well as the preliminary geologic and geochemical maps. These maps apparently helped the exploration efforts of the companies in the area, particularly in the low-lying areas within the broad river valleys.

\section{Metals}

Kennecott Exploration has been working for several years on land owned by the

Sitnasuak and Bering Straits Native Corporations, mainly in the vicinity of Rock Creek and Aurora Creek northwest of Nome. In 1994 an exploration agreement was signed by Kennecott, the Sitnasuak Corporation, and the Bering Straits Native Corporation to evaluate corporation lands. This agreement will result in annual exploration expenditures of about $\$ 2$ million over the next three years. During the year the company drilled 5,600 feet $(1,707$ meters) of core and 18,000 feet $(5,486$ meters) of reverse-circulation hole, as well as numerous shallow auger holes. Several members of the exploration crew are local Native residents.

Kennecott also had a significant exploration program near Candle in the northern part of the Seward Peninsula.

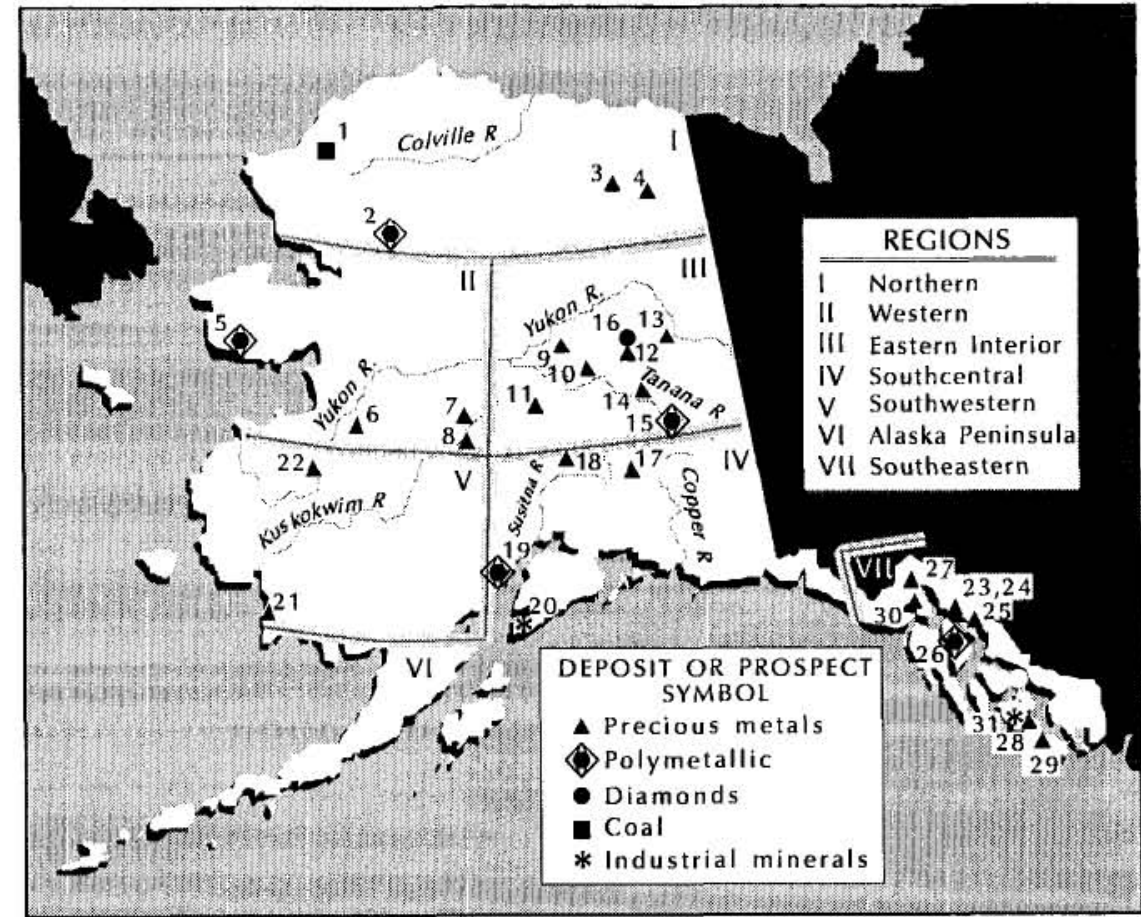

\section{Northern Region}

1. Kuchiak Mine-Arctic Slope Consulting Group

2. Ambler Mineral BeltKennecott Exploration, Teck Exploration, Cominco Alaska, NANA Regional Corp.

3. Wiseman Area--Silverado Mines (U.S.) Inc.

4. Chandalar Lake-Hamlyn Estates

II Western Region

5. Nome Area-Kennecott Exploration, Cominco Alaska

6. Illinois Creek-USMX Inc.

7. Nixon Fork-Consolidated Nevada Goldfields

8. Vinasale Mountain-ASA Inc.

III Eastern Interior Region

9. Sawtooth Mountain-ASA/ Montague J-V.

10. Fairbanks district
a. True North-LaTeko Resources Ltd.

b. Fort Knox-Fairbanks Gold Mining Inc.

c. Ester Dome-Silverado Mines (U.S.) Inc.

d. General-Amax Gold Exploration, Placer Dome (U.S.) Inc.

11. Liberty Bell-Noranda Exploration

12. Stoneboy Creek-WGM Sumitomo

13. Circle district-Amax Gold Exploration Corp.

15. Tok area-American Copper and Nickel Co.

16. Clums Fork-Apollo Resources Inc.

IV Southcentral Region

17. Zackley-Noranda Exploration

18. Golden Zone-Addwest Minerals Inc.

19. Johnson River-Westmin Resources Ltd.

20. Red Mountain-Addwest Minerals Inc.

V Southwestern Region

21. Goodnews Bay-Starcore Resources Ltd.

22. Stuyahok-Calista Corp.

\section{Alaska Peninsula Region}

VII Southeastern Region

23. Kensington-Couer Alaska Inc.,/ Echo Bay Alaska Inc.

24. Jualin-Couer Alaska Inc.

25. Alaska-Juneau-Echo Bay Alaska Inc.

26. Greens Creek-Kennecott Greens Creek Mining Co.

27. Haines-Kennecott Exploration Inc.

28. Hetta Inlet-American Copper and Nickel Co.

29. Dolomi-Sealaska Corp.

30. Dream-Henkins/Eichman

31. Calder Bay-Sealaska
14. Richardson district-Tri-Valley

Figure 5. Selected exploration projects in Alaska, 1994. 
Cominco Alaska Exploration was also active north of Nome, working on its own claims and several thousands of acres of leases. Most of Cominco's 1994 work, including some drilling, was conducted at the Rocky Mountain Creek massive sulfide deposit 20 miles (32 kilometers) northeast of Nome.
On-Line Exploration Services had a crew operating in the Kigluaik area mapping and sampling the highgrade graphite occurrences belonging to N.B. Tweet and Sons. The crew was joined by some of the State Division of Geological \& Geophysical Surveys staff who were also operating in the same area.

Table 3. Reported exploration expenditures in Alaska by commodity, 1982-94

\begin{tabular}{|c|c|c|c|c|c|c|c|}
\hline & $\begin{array}{c}\text { Base } \\
\text { metals }\end{array}$ & Polymetallic $^{\mathrm{a}}$ & $\begin{array}{c}\text { Precious } \\
\text { metals }\end{array}$ & $\begin{array}{l}\text { Industrial } \\
\text { minerals }\end{array}$ & $\begin{array}{c}\text { Coal } \\
\text { and peat }\end{array}$ & Other & $\begin{array}{l}\text { Years } \\
\text { Total }\end{array}$ \\
\hline 1982 & $\$ 31,757,900$ & N/A & $\$ 10,944,100$ & $\$ \quad \ldots$ & $\$ 2,900,000$ & 15,300 & $\$ 45,617,300$ \\
\hline 1983 & $9,758,760$ & N/A & $20,897,555$ & $2,068,300$ & $1,338,454$ & 70,000 & $34,133,069$ \\
\hline 1984 & $4,720,596$ & N/A & $14,948,554$ & 270,000 & $2,065,000$ & 279,500 & $22,283,650$ \\
\hline 1985 & $2,397,600$ & N/A & $6,482,400$ & - & 270,000 & - & $9,150,000$ \\
\hline 1986 & $1,847,660$ & N/A & $6,107,084$ & 170,000 & 790,000 & -- & $8,914,744$ \\
\hline 1987 & $2,523,350$ & N/A & $11,743,711$ & 286,000 & $1,150,000$ & 31,000 & $15,734,061$ \\
\hline 1988 & $1,208,000$ & N/A & $41,370,600$ & 160,200 & $2,730,000$ & -. & $45,468,800$ \\
\hline 1989 & $3,503,000$ & N/A & $43,205,300$ & 125,000 & 924,296 & 5,000 & $47,762,596$ \\
\hline 1990 & $5,282,200$ & N/A & $57,185,394$ & 370,000 & 321,000 & 97,000 & $63,255,594$ \\
\hline 1991 & $4,789,500$ & N/A & $34,422,039$ & 92,000 & 603,000 & 2,000 & $39,908,539$ \\
\hline 1992 & $1,116,000$ & $3,560,000$ & $25,083,000$ & 25,000 & 425,000 & -. & $30,209,000$ \\
\hline 1993 & 910,000 & $5,676,743$ & $23,382,246$ & 163,500 & - & 125,000 & $30,257,489$ \\
\hline 1994 & 600,000 & $8,099,054$ & $18,815,560$ & 225,000 & $2,554,000$ & 810,000 & $31,103,614$ \\
\hline TOTAL & $\$ 70,414,566$ & $\$ 17,335,797$ & $\$ 314,587,543$ & $\$ 3,955,000$ & $\$ 16,070,750$ & $\$ 1, \mathbf{4 3 4}, \mathbf{8 0 0}$ & $\$ 423,798,456$ \\
\hline
\end{tabular}

a Polymetallic deposits considered as a separate category for the first time in 1992.

N/A-Not available.

- Not reported.

Table 4. Reported exploration expenditures and employment in Alaska by commodity and region, 1994

$\begin{array}{lllllll}\text { Northern } & \text { Western } & \begin{array}{c}\text { Eastern } \\ \text { interior }\end{array} & \begin{array}{c}\text { South- } \\ \text { central }\end{array} & \begin{array}{c}\text { South- } \\ \text { western }\end{array} \text { Peninsula } & \begin{array}{c}\text { South- } \\ \text { eastern }\end{array} & \text { Total }\end{array}$

Base metals

Polymetallic $^{\mathrm{a}}$

Precious metals
Placer

Lode

Coal and peat

Industrial minerals

Other $\begin{array}{ll}\text { Eastern } & \text { South- } \\ \text { interior } & \text { central }\end{array}$

Exploration expenditures

Total

$\cdots$
320,000
$1,010,000$
150,000
$2,554,000$
$\cdots$
10,000

$-$

$1,014,000$

$2,615,05$

100,000

$119,000 \quad 318,160 \quad 151,000$

$5,400,000 \quad 4,371,000 \quad 950,000$

-. $\quad$-.

- $\quad 50,000$

-. 800,000
$4,044,000$

$6,533,000$

western Peninsula eastern

Total

$\mathbf{8 , 1 5 4 , 2 1 4} \quad 1,571,000 \quad \mathbf{7 4 8 , 0 0 0}$

$\begin{array}{rcrr}-- & -- & 500,000 & \mathbf{6 0 0 , 0 0 0} \\ 200,000 & -- & 3,610,000 & \mathbf{8 , 0 9 9 , 0 5 4} \\ & & & \\ 98,000 & -- & 3,400 & \mathbf{1 , 6 9 9 , 5 6 0} \\ 450,000 & -- & 5,795,000 & \mathbf{1 7 , 1 1 6 , 0 0 0} \\ -- & -- & -- & \mathbf{2 , 5 5 4 , 0 0 0} \\ - & -- & 145,000 & \mathbf{2 2 5 , 0 0 0} \\ -- & - & -- & \mathbf{8 1 0 , 0 0 0}\end{array}$

Exploration employment

\begin{tabular}{|c|c|c|c|c|c|c|c|c|}
\hline \multicolumn{9}{|l|}{ Employment } \\
\hline Workdays & 4,788 & 10,149 & 11,478 & 1,626 & 1,128 & $\cdots$ & 18,020 & 47,189 \\
\hline Workyears $^{\mathrm{b}}$ & 18 & 39 & 44 & 6 & 4 & $\cdots$ & 69 & $182^{\mathrm{c}}$ \\
\hline $\begin{array}{l}\text { Number of companies } \\
\text { reporting }\end{array}$ & 10 & 11 & 30 & 10 & 5 & $\ldots$ & 8 & 74 \\
\hline
\end{tabular}

- No expenditures reported

a Jade, platinum, gemstones.

based on 260-day workyear.

${ }^{c}$ Small discrepancy on total due to rounding

$\mathrm{d}_{\text {Same companies active in more than one area. }}$ 
Kenneth Hughes reported exploring for placer gold in the same area, and Lost River Mining worked in the Tripple Creek area east of Nome evaluating gold placer potential. Steve Pomrenke reported a trenching and sampling program seeking gold in the Nome area.

On-Line Exploration Services evaluated the Win tin-silver prospect about 20 miles (32 kilometers) north of McGrath, where the U.S. Bureau of Mines investigated the potential in 1990-91. At the Won prospect, approximately 20 miles (32 kilometers) northeast of the Win prospect, the bureau estimated a minimum resource of 25.3 million pounds (11.54 million kilograms) of tin. These are two of several prospects in the northern part of the Kuskokwim Mountains between McGrath and Manley that contain tin, silver, bismuth, antimony, and tellurium as complex sulphosalts.

Consolidated Nevada Goldfields Corporation (CNGC) had another busy year in 1994 at the Nixon Fork property, northwest of McGrath. The company drove two 11-by-10-foot (3.3-by-3-meter) declines, and from these declines cut several access drifts to explore mineralized zones in the Crystal-Garnet and the Mystery orebodies. The company also completed drifts on four other orebodies: Garnet Deep, Garnet Low, Old Crystal, and M-700. A total of 3,000 feet ( 914 meters) of underground development was completed during the year.
In addition to the underground work, a total of 25,000 feet (7,620 meters) of surface and underground drilling expanded total mineable reserves to 122,549 tons at 1.33 ounces per ton of gold, which is 163,030 contained ounces $(111,250$ tonnes at 45.63 grams per tonne with 5,071 kilograms of contained gold) with possible reserves of 39,160 tons grading 0.96 ounces per ton, or 37,600 contained ounces $(35,550$ tonnes at 32.94 grams per tonne and 1,170 kilograms of contained gold). These reserves are contained within previously discovered orebodies, but the drilling also identified six new areas of mineralization, called the Recreation, High Grade, J-5A, and Southern Cross, all of which are open ended (fig. 6).
Figure 6. Nixon Fork Mining Company employee Arnold Andrews from McGrath photographs diamond-drill core from the Nixon Fork gold-copper deposit about 35 miles (56 kilometers) northeast of McGrath. (Photo by Richard Flanders)

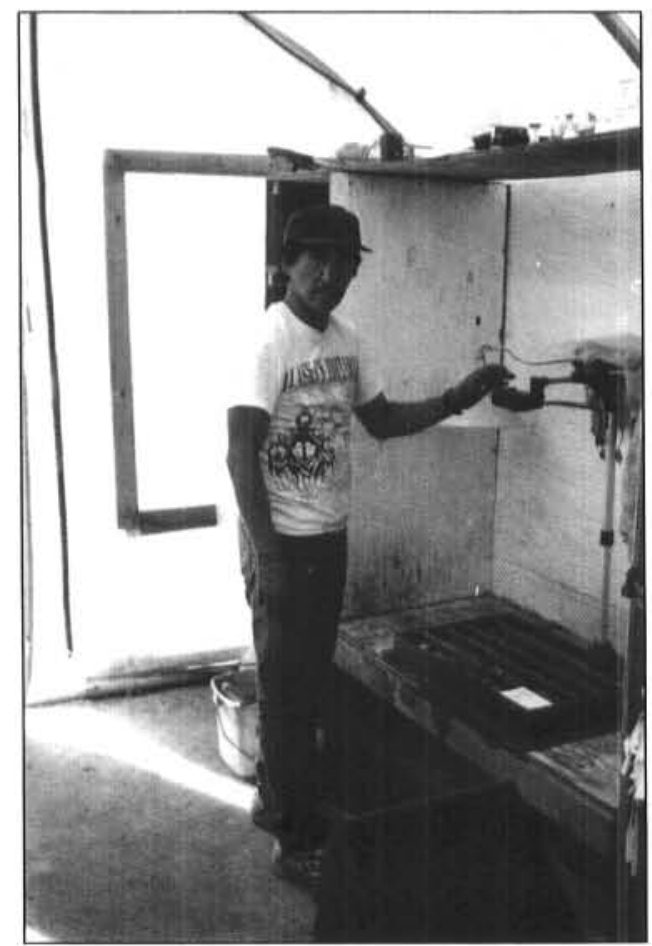


CNGC will begin construction of the mine plant in 1995 and initiate full-scale mining by the fourth quarter of 1995 at a rate of 60,000 ounces $(1,866$ kilograms) per year with a cash-cost of $\$ 169$ per ounce ( $\$ 5.44$ per gram).

At Vinasale Mountain, south of McGrath, ASA Inc. drilled 17,265 feet ( 5,262 meters) of core, mainly as infill of the previous drilling on the Central Zone orebody. This drilling also intersected a new deeper body of gold mineralization. The veins are steeper than originally estimated, and the deposit is open at depth. Within the Central Zone the gold is associated with disseminated pyrite, arsenopyrite, and stibnite, with minor boulangerite, sphalerite, and galena. Higher grades are associated with several bodies of monzonite intrusion breccia and hydrothermal breccia with pervasive quartz-dolomite-sericite alteration within the 69 million year-old monzonite stock. In the nearby Northeast Zone the mineralization of pyrite, arsenopyrite, and stibnite is hosted within narrow quartz-dolomite veinlets that are localized by an expansive set of northeast-trending fractures. The ore at Vinasale is refractory, but 98 percent reports to a flotation concentrate, and ASA has contracted with Signet Technologies to review the amenability options. The current resources in the Central Zone at Vinasale Mountain are 11.3 million tons (10.3 million tonnes) grading 0.070 ounces gold per ton ( 2.4 grams per tonne) for a total of 789,000 ounces $(24,540$ kilograms) of gold.

ASA also conducted regional exploration in the northern Kuskokwim Mountains.

Illinois Creek is another advanced exploration property in western Alaska. In the late summer of 1994, USMX Inc. of Lakewood, Colorado, agreed to purchase the rights to mine the deposit from North Pacific Mining Co. (NPMC), a subsidiary of Cook Inlet Region Inc. Early in 1995 NPMC signed the agreement that allows NPMC the right to a 25 percent working interest that is convertible to a 5 percent net smelter return. The property is entirely on lands owned and managed by the State of Alaska. The 1994 exploration program included 8,108 feet (2,467 meters) of diamond drilling and confirmed the 3.9 million tons ( 3.53 million tonnes) mineable reserve grading 0.088 ounces per ton (3.02 grams per tonne) of gold and 1.7 ounces per ton (58.2 grams per tonne) of silver. USMX began the permitting process in late 1994 with a view to moving in equipment in late 1995 and beginning the mining in 1996.

\section{EASTERN INTERIOR REGION}

Reported exploration expenditures in 1994 were $\$ 8.15$ million, up 16 percent from the $\$ 7.05$ million reported in 1993. Most of the investment was in hardrock gold and polymetallic exploration. At the request of the Fairbanks Industrial Development Corpo- ration, the state contracted for airborne geophysical surveys of 600 square miles (1,554 square kilometers) in the Fairbanks mining district and 130 square miles (337 square kilometers) in the Richardson district about 60 miles (97 kilometers) southeast of Fairbanks. The aeromagnetic and electromagnetic data acquisition cost about $\$ 361,000$, or about $\$ 487$ per square mile $(\$ 188$ per square kilometer) with flight lines one-quarter-mile (0.4-kilometer) apart. Staking of large blocks of mining claims and prospecting sites began in late fall and continued through the winter partly in anticipation of the results of the airborne surveys, which became available in February, 1995. The University of Alaska also contracted for an airborne survey of about 20 square miles ( 32 square kilometers) of University-owned land just to the east of the Fairbanks survey.

\section{Metals}

As in past years, most of the exploration activity in 1994 has been in the Fairbanks area and the surrounding hills. La Teko Resources Ltd., which is managed through Ryan Lode Mines Inc., continued with baseline studies and geotechnical work at its Ryan Lode Mine on Ester Dome west of Fairbanks. Silverado Mines (U.S.) Inc. had a reverse-circulation drilling program on Ester Dome testing some of the targets developed by American Copper and Nickel Co. during its lease of the past few years.

La Teko also conducted a major exploration program at its True North property west of Pedro Dome drilling 2,042 feet (622 meters) of core, and 52,085 feet $(15,875$ meters) of reverse-circulation hole (fig. 7$)$. Proven and probable reserves at True North as certified by Mine Development Associates of Reno are 446,000 ounces $(13,872$ kilograms) of gold, with an average grade of 0.065 ounces per ton ( 2.72 grams per tonne) of gold, and with a 2.14:1 stripping ratio.

This reserve is contained in two discrete orebodies, the Hindenburg and the Shepard, which are aligned along northeast-trending structures. La Teko expects further exploration to determine continuity. Mine Development Associates has also identified inferred reserves of $6,000,000$ tons $(5,447,000$ tonnes) grading 0.034 ounces per ton ( 1.16 gram per tonne) of gold in the area of the two deposits.

True North is probably the most promising new gold discovery made in the eastern interior since the discovery of the Fort Knox Deposit in the mid-1980s. The deposit is important because until quite recently the terrane in which it occurs was not thought to be prospective for bulk-tonnage mines, although the narrow high-grade stibnite veins at the Hindenburg Mine have been known since the earliest days of the mining camp. The gold is associated with quartz-siderite veins and veinlets emplaced in a black carbonaceous quartzite 
unit, which is itself part of a sequence containing stratiform calcareous eclogites. At the end of the season a wildcat hole drilled 1,500 feet (457 meters) from the nearest drill hole on the True North property intercepted a mineralized dike of altered porphyritic igneous rock, which could be indicative of a source of the gold mineralization.

La Teko also announced that it could earn up to 60 percent interest in International Freegold Mineral Development's Golden Summit property, which contains several of the most important historic hard-rock mines of the Fairbanks district within the 11-mile (18-kilometer) strike-length of the property. From west to east some of the properties are the Newsboy, Cleary Hill, Christina, Nordale, McCarty, and Hi-Yu Mines. Between the McCarty and the Hi-Yu deposits, International Freegold has been exploring a prospect called the Too Much Gold, where trenches within the 10,000-foot-long (3,048-meter) gold-in-soil anomaly have yielded intercepts up to 110 feet ( 34 meters) of 0.060 ounces of gold per ton (2.06 grams per tonne) and 655 feet (200 meters) of 0.022 ounces of gold per ton ( 0.75 grams per tonne).

Previous drilling included 70 feet ( 21 meters) of 0.090 ounces of gold per ton (3.09 grams per tonne) and 25 feet (7.6 meters) of 0.16 ounces of gold per ton (5.5 grams per tonne). Avalon Development Co. spent part of the season doing geochemical and geophysical surveys within the Golden Summit block, and late in the year began to acquire ground for Placer Dome U.S. Inc. Several deep drill holes were completed on behalf of Placer Dome.

Following a press release about the results of the True North 1994 exploration, Placer Dome U.S. Inc. began a land acquisition program which continued into the winter in the eclogite-bearing terrane hosting the True North property. Fairbanks Gold Mining Inc., a subsidiary of Cyprus-Amax, and owner of the Fort Knox Mine, also began consolidating its land position during the fall of 1994. During the summer the company had a modest drilling program to test targets east of the minesite and continued evaluation of the Gil claims leased from Teryl Resources Ltd. One hole of the 28-hole program intercepted 90 feet ( 27 meters) averaging 0.067 ounces per ton (2.3 grams per tonne) of gold.

By midsummer Fairbanks Gold Mining Inc. received its final permit from the U.S. Army Corps of Engineers, which allowed the company to begin earthwork preparatory to mine development.

About 70 miles (112 kilometers) northwest of Fairbanks, near the village of Rampart, ASA Inc. working as ASA/Montague continued to evaluate igneous-hosted gold prospects within a block of land owned by the

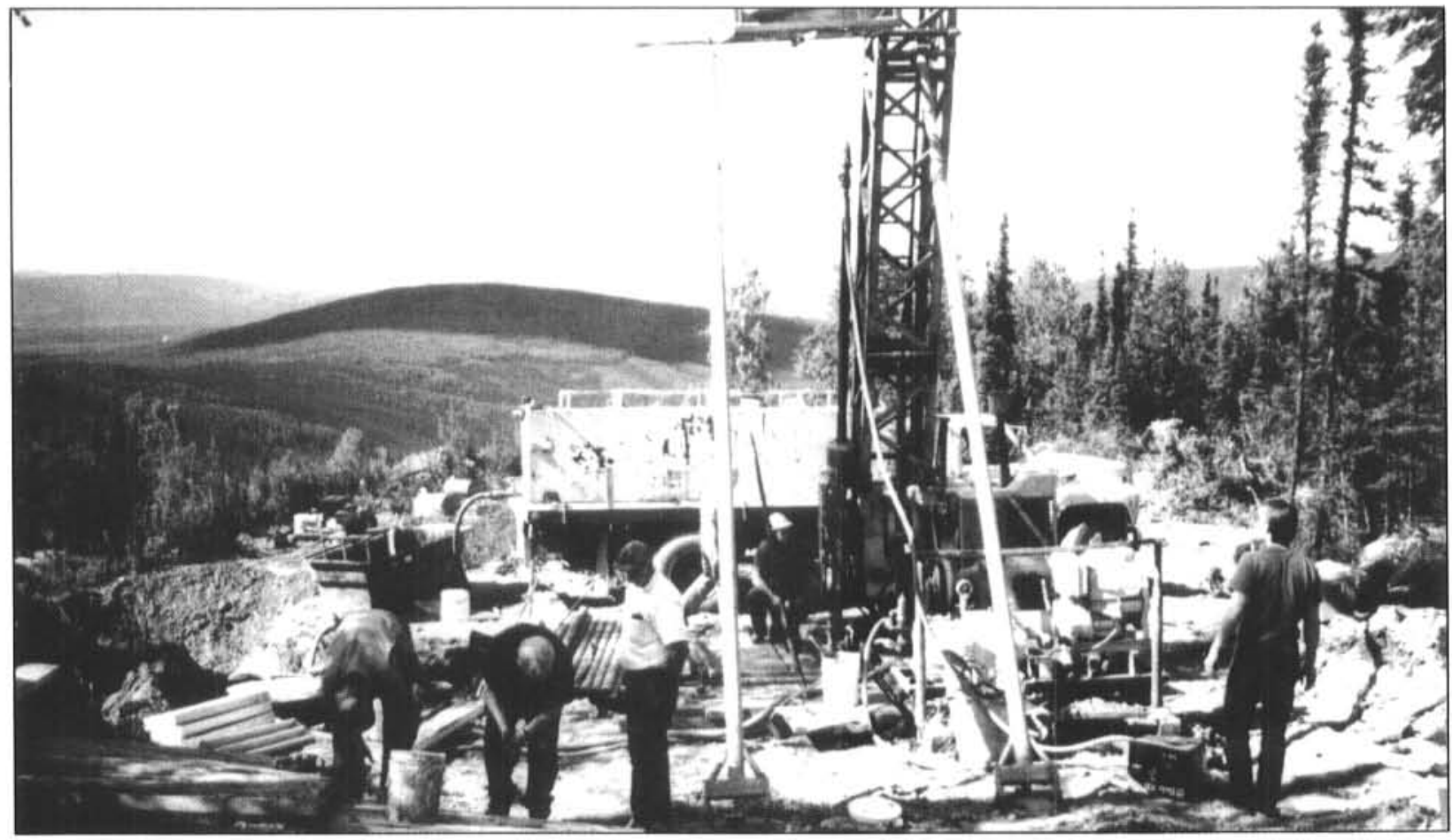

Figure 7. A drill team explores the True North gold deposit about 9 miles (15 kilometers) north of Fairbanks. Work in 1994 proved up approximately 446,000 ounces (13,872 kilograms) of gold in a shallow, synformal ore deposit originally known as the Hindenberg Prospect. More work is planned in 1995. (Photo by Ryan Lode Mines Inc.) 
Doyon Native Corporation. The Huron and Peak 4051 prospects align along a major northeast-trending fault which controls emplacement of a series of gold-related Cretaceous plutons and dikes. Both prospects exhibit intense silicification as flooding and veinlets. Rock samples from the Peak 4051 prospect contain up to 0.20 ounces per ton (6.9 grams per tonne) of gold, and from the Huron prospect up to 0.67 ounces per ton (23.0 grams per tonne) of gold. At the Chapman Creek prospect a swarm of monzonite dikes exhibit intense sericite-dolomite and silica alteration, and contain up to 0.035 ounces per ton (1.2 grams per tonne) of gold. Gold-in-soil anomalies at all these prospects indicate the potential for substantial size, and they may be drilled in 1995.

About 80 miles (128 kilometers) east of Fairbanks, WGM Inc., working in a joint-venture with Sumitomo Metal Mining of Canada, had an aggressive exploration program in the headwaters of the Salcha River near Stoneboy Creek.

Modest exploration continued in the Richardson mining district 50 miles (80 kilometers) southeast of Fairbanks. Tri-Valley Corporation, the major claimholder in the area, collected bulk samples from the Democrat Mine, and re-analyzed portions of the drill-core collected in 1988. Late in the year the company announced that metallic-screen-fire assay of a 10 -foot (3-meter) section of core from the surface, and a 5-foot (1.5-meter) section from a depth of 225 feet (69 meters) assayed at 3.4 ounces of gold per ton (116.6 grams per tonne) rather than at the low values reported previously. TriValley intends to pursue confirmation drilling in 1995.

The state-sponsored airborne geophysical survey flown in 1994 of the Richardson district should be of great assistance in this area of heavy vegetation and silt cover.

At the Liberty Bell Mine near Healy, 100 miles (160 kilometers) southwest of Fairbanks, Noranda Exploration Inc. acting as agent for Hemlo Gold Mines Inc., trenched several anomalies that were discovered through geochemistry and geophysics. The property was under lease from Liberty Bell Mining Company.

American Copper and Nickel Company (ACNC) had a major exploration program in the Delta district near Tok. The program worked a joint-venture on and around several polymetallic prospects owned by Pacific Northwest Resources Inc.

Cyprus-Amax Gold Co. based a crew in Circle for most of the summer to prospect for gold. The company was also active in the Fairbanks district. BS Mining also dug test-pits in the Circle area. Teck Exploration, Cominco Alaska Exploration, and Kennecott Exploration also fielded exploration crews at undisclosed locations in the interior. ASARCO examined some property but did no regional exploration. Grateful Dog Mining continued exploration with trenching on Hattie Creek.
A number of the placer miners in interior Alaska reported some exploration activity. In the Fairbanks district, Alder Creek Mines did some bulk sampling on the right limit of Fairbanks Creek, and David Johnson of Coromandel Mining Co. drilled the TAT claims in Bear Creek south of Fairbanks Creek. Herning Exploration and Mining completed minor exploration at Palmer Creek on the Upper Chena River, and Ted Leonard and Carl Redfern worked on the Salcha River.

Twogood Construction tested methods for suction dredging in deep water on Goldstream Creek and plans to continue with a larger test-program in 1995.

In the Manley-Eureka area Arnold Mason spent a few days prospecting, and Donval Simpson spent a month test sluicing.

The Circle area was a little more active than last year, with five companies and groups reporting placer exploration programs. BHD Mining cut 19 exploration trenches on the North Fork of the Twelvemile River working with DOXAUCO Enterprises Inc., and Colledge Enterprises reported exploration on Bottom Dollar Creek. Paul and Company did some reversecirculation drilling on Porcupine Creek but plan to move to Fryingpan Creek. Bob Cacy of Points North was active on both Portage and Crooked Creeks. David Underwood tested ground in several Circle district creeks during 1994.

Elsewhere in the interior, Fred Cook prospected in the Portage Creek drainage north of Mt. Hayes, D'Log Industries Inc. drilled and sampled on No-Name Creek in the Bonnifield district, and Glacier Six Enterprises reported trenching in Broxson Gulch in the Mt. Hayes area.

\section{IndUSTRIAL. MineraLs}

The only reported exploration for industrial minerals was by Lakloey Inc. with Stevens Exploration in the Tenderfoot area of the Richardson district. The work consisted of trenching and mapping for riprap and rock.

\section{Diamond Exploration}

Apollo Resources Inc., on behalf of Verdstone Gold Co., explored for diamonds in the Clums Fork-Far Mountain area, about 70 miles (112 kilometers) eastnortheast of Fairbanks. Apollo drilled about 3,000 feet ( 914 meters) of 5.5-inch (14 centimeter) reverse-circulation holes to secure about 24 tons ( 21.8 tonnes) of cuttings, sampled in intervals of 2.5 feet ( 0.76 meters). The samples were transported to Fairbanks where they were comminuted in a small ball mill and then passed over a grease table to collect any diamonds present.

Apollo also collected about 2 cubic yards ( 1.5 cubic meters) of gravel at eight sites for heavy-mineral concentrate studies. These samples were shoveled through a small jig plant before being flown to Fairbanks for heavy-mineral separation. 


\section{SOUTHCENTRAL REGION}

In 1994 exploration investment in the southcentral region was $\$ 1.57$ million, about the same as the $\$ 1.54$ million reported in 1993 . Highlights include renewed activity at the Golden Zone Mine in the Upper Chulitna mining district, at Johnson River on the west side of Cook Inlet, and at Red Mountain south of Seldovia.

\section{Metals}

Addwest Minerals Inc. used diamond and reverse circulation drilling to evaluate the Golden Zone Mine in the Upper Chulitna mining district near Cantwell (fig. 8). This former producing gold-copper mine is hosted in a Late Cretaceous intrusive breccia pipe. Recent exploration has identified the host rocks of the pipe as a shoshonitic composite intrusive body consisting of small plugs of biotite quartz diorite, and plugs and dikes of mafite. Mafite is a silica-carbonate rock formed by the pervasive alteration of dikes of intermediate to mafic composition. These mafite dikes cut the quartz diorite and the sheeted vein zones that flank the main breccia pipe.

Westmin Resources Ltd. continued mapping and sampling at the Johnson River polymetallic property near Iliamna Volcano. The property is managed by North Pacific Mining Co., for owner Cook Inlet Region Inc., an Alaska native regional corporation. This deposit is hosted in volcanic and volcaniclastic rocks of the Jurassic Talkeetna Formation. Drilled reserves at a $\$ 50$ per ton ( $\$ 45$ per tonne) cutoff are 1.1 million tons ( 997,542 tonnes) at 8.37 percent zinc, 1.17 percent lead, 0.76 percent copper, 0.302 ounces per ton (10.35 grams per tonne) of gold, and 0.23 ounces per ton $(7.84$ gram per tonne) silver. The 1994 work, including metallurgical testing of the ore, will lead to a prefeasibility report.

East of Valdez Creek in the Alaska Range, Noranda Exploration had a small drilling program on behalf of Hemlo Gold at the Zackley copper- and gold-bearing skarnmarble prospect. The prospect is owned by Pacific Northwest Resource Company. Previously reported reserve estimates are 1.4 million tons ( 1.27 million tonnes) grading 2.6 percent copper and 0.175 ounces per ton (6.0 grams per tonne) of gold.

An American Copper and Nickel Co. crew prospected for copper and zinc at undisclosed locations in the southcentral area.

Several gold placer exploration programs were reported in the southcentral area in
1994. Empire Exploration was active in the Yentna area, and Ed Ellis prospected on Independence Creek and on Lake Creek. Tim Geirrmann prospected at Paxson, Petersville, Hope, and Hatcher Pass. Halloran Operation sampled the Kahiltna River. Howard Hunt reported exploration in the Silver Creek area near Iliamna and on Big Boulder Creek at Collinsville.

\section{Industrial Minerals}

North Pacific Mining Co. worked with Addwest Minerals at Red Mountain near Seldovia and examined the possibility of using olivine from the ultramafic intrusive rocks for industrial purposes such as casting media, firebricks, or sandblasting.

\section{SOUTHWESTERN REGION}

Exploration expenditures in 1994 were $\$ 748,000$, down slightly from the $\$ 843,000$ reported in 1993 . There was no exploration for any commodity other than metals.

\section{Metals}

Starcore Resources Ltd. worked with Alaska Earth Sciences and the Calista Native Corporation to drill the Goodnews Bay Red Mountain and Susie Mountain areas

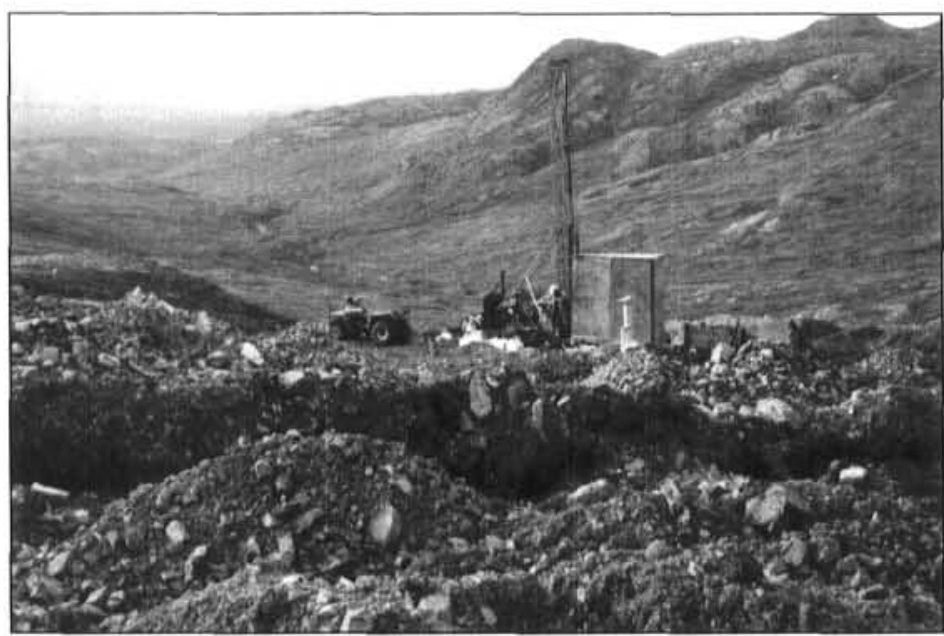

Figure 8. Addwest Mineral Inc. explores the Golden Zone coppersilver-gold deposit in the Chulitna district of southcentral Alaska. The mine produced 1,581 ounces (49 kilograms) of gold, 8,617 ounces (268 kilograms) of silver, and 42,000 pounds (19,051 kilograms) of copper during a brief production period prior to World War II. Reserves at the end of 1993 amounted to 230,000 ounces $(7,153$ kilograms $)$ of gold and significant copper and silver in about 2.0 million tons (1.8 million tonnes) of ore. During 1994 Addwest Mineral's exploration revealed significant copper-enriched mineralization. (Photo by C.C. Hawley) 
for the source of the placer platinum. Prior to 1976 these placers were the largest source of platinum group elements (PGEs) in the United States.

A Calista Corporation crew drilled and sampled gold placer deposits at Stuyahok in the Holy Cross Quadrangle.

Cominco Alaska Exploration fielded exploration crews in the southwestern district at several undisclosed locations.

Misco-Walsh Mining continued exploration at the Golden Horn property near Flat and continued to resolve metallurgical problems associated with the complex refractory ores on the property.

James Wylie conducted a modest exploration program at the Mountain Top mercury-gold mine in 1994.

Only three placer operations reported exploration activity. Paul Sayer prospected a small amount at the Little Creek Mine. Lyman Resources of Alaska ran an augerdrill program on Queen Gulch near Donlin Creek. Sphinx Natural Resources, in partnership with Malvy Technology Inc., had a substantial gold placer exploration program on Spruce and Trail Creeks in the Ruby-Poorman district.

\section{ALASKA PENINSULA REGION}

The only exploration activity reported for the peninsula was a cursory examination of a gold-silver showing in Terror Bay by Koniag Inc., the Native regional corporation.

\section{SOUTHEASTERN REGION}

Reported exploration investment in southeast Alaska of $\$ 10.1$ million was more than in any other region of the state, although it was only 64 percent of the $\$ 15.7$ million spent in 1993 . However, these numbers should be qualified because the large advanced exploration projects at the A-J, Kensington, and Greens Creek Mines shifted towards development between 1993 and 1994. Hence the pre-production investment in the southeastern region, which is the sum of exploration and development expenditures, was $\$ 31.1$ million in 1994 , almost double the $\$ 16.3$ million invested in 1993 .

In addition to large programs at these mine sites, several companies, including American Copper and Nickel, Coeur Alaska, Kennecott Exploration, and Sealaska report substantial regional exploration programs. Except for some industrial mineral exploration by Sealaska, all the rest of the projects were for metals.

\section{Metals}

For several years Echo Bay Alaska Inc. has been involved with two major projects near Juneau-the A-J Mine and the Kensington Mine. The A-J Mine is located in Mt. Roberts immediately behind the town of Juneau, and, in fact, the city is built partly on the rock dumps created during the early days of mining at the A-J. Until the mine closed in 1944 it was the economic base. Since then Juneau has grown as the capital city of Alaska and as a tourist destination during the summer months when the state legislature is not in session.

The 1994 exploration program at the A-J Mine consisted of drifting and drilling throughout the mine to expand or confirm existing reserves, which at last report were 105.7 million tons ( 96 million tonnes) at a grade of 0.05 ounces per ton (1.7 grams per tonne) of gold.

Baseline exploration work, including some diamond-drilling, continued at the Kensington Project about 35 miles ( 56 kilometers) north of Juneau.

Echo Bay also had a modest exploration program at the Gold Fork prospect on the Gold Fork of Carlson Creek. Gold Fork is a metamorphic vein located in highgrade metamorphic rocks several miles north of the A-J deposit. The prospect has been developed by several short adits and trenches that were dug before 1940 . Echo Bay drilled the prospect, staging out of Juneau with helicopter support, rather than from a remote camp. Further work is planned for 1995.

Coeur Alaska now owns the rights to the Jualin Mine a few miles southeast of the Kensington Mine on opposite sides of the mountain. Coeur's exploration program mapped and sampled at the mine and estimated reserves of 1.07 million tons ( 0.97 million tonnes) with 0.349 ounces per ton ( 12 grams per tonne) of gold.

The Greens Creek Mine project is a joint-venture between Kennecott and Hecla, with Exalas Resources Corporation as a minority shareholder. Kennecott, the project operator, increased the workforce from 25 to 45 to accelerate work on the newly discovered southwest extension orebody

Kennecott Greens Creek Mining Company completed 4,700 feet ( 1,433 meters) of drifts to drill 130,000 feet (39,624 meters) of core with holes on 50-foot (15-meter) centers for better definition of the southwest orebody at the Greens Creek Mine. Late in 1994 the reserves of this orebody were reported to be 2.0 million tons ( 1.81 million tonnes) with grades of 13.5 percent zinc, 5.5 percent lead, 0.27 ounces per ton $(9.25$ grams per tonne) of gold, and 33 ounces per ton, (1,131 grams per tonne) silver. Approximately 11 million tons (10 million tonnes) of the original orebody remain, with grades of 0.12 ounces per ton ( 4.1 grams per tonne) of gold, 13.30 ounces per ton (456 grams per tonne) silver, 4.0 percent lead, and 12.8 percent zinc. Total combined reserves and resources for the property were reported as 18 million tons ( 16.34 million tonnes).

Significantly, some exceptionally high-grade precious-metal zones, especially gold, were discovered during the drilling of the southwest extension mineral 
zone. Company geologists estimate that about 5 percent of southwest's orebody will be shipped as ore because of its high grades of precious metals, and the remainder will be shipped as concentrates to various smelters around the world.

Kennecott Exploration also had a regional reconnaissance exploration program in southeast Alaska and completed a moderate diamond-drill program at the Glacier Creek massive-sulfide deposit near Haines.

American Copper and Nickel Co. continued exploration for polymetallic massive-sulfide deposits in the Wales Group rocks near Hetta Inlet of Prince of Wales Island. The 1994 work included mapping, geochemistry and geophysics. Hyak Mining reported claim maintenance of its Red Diamond and East Point polymetallic claims.

Sealaska Corporation, the southeast region's Native corporation, had a very active year, with a drill program for gold at Dolomi on Prince of Wales Island and a substantial reconnaissance exploration program for polymetallic deposits.

Alaska-Dano Mines conducted minor surface mapping and sampling on its patented claims near Funter Bay, west of Juneau. Sporadic base- and precious-metal anomalies have been found in soil and rock samples from a mixed metavolcanic and metasedimentary rock package within the claims.

It is uncertain whether this sequence correlates with similar lithologies at the Greens Creek Mine.

There was limited exploration for placer gold in the Porcupine Creek area near Haines by Snow Lion Mining and by the Foster Operation.

\section{Industrial Minerals}

Sealaska reported drilling its high-purity, chemicalgrade limestone deposit at Calder Bay on Prince of Wales Island.

\section{DEVELOPMENT}

Mineral development expenditures in Alaska in 1994 were $\$ 44.94$ million, up 62 percent from $\$ 27.67$ million the previous year (tables 6 and 7). Full-scale mine and infrastructure development at Fort Knox, Nixon Fork, and Healy Clean Coal projects should result in even higher expenditures in 1995.

Figure 9 illustrates the breakdown by commodity of how the industry spent its development dollars. Figure 10 shows the locations of selected development projects throughout the state.

\section{NORTHERN REGION}

\section{Metals}

The reported 1995 development expenditures in the northern region were $\$ 12.6$ million, up 15 percent from

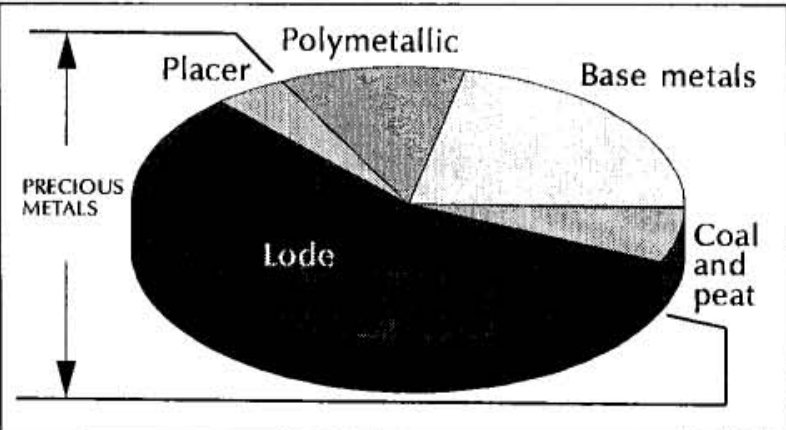

Figure 9. Development expenditures by commodity, 1994. the $\$ 10.96$ million reported in 1993. Most of this work was at Cominco Alaska's Red Dog Mine, where modifications to the grinding and milling circuits continued from the previous year. This substantial upgrade enabled Cominco to increase production in 1994 and to achieve a cleaner zinc concentrate.

Silverado Mines (U.S.) Inc. had another busy year on Nolan Creek near Wiseman in the eastern Brooks Range where it completed the camp, upgraded the roads, and drove a decline to access underground placer gold reserves on a channel on Marys Bench. The company also stripped ground for opencut mining adjacent to the underground operation. Although the area had the worst flooding in living memory in August, the settling ponds, and the reclamation of the Thompson's Pup minesite came through virtually unscathed (fig. 11). The company was able to spare equipment to assist with levee construction to protect Wiseman from the flood, and received a commendation for its efforts from the people of Wiseman.

In late 1994 Silverado began a 700 -foot (212-meter), 15-percent decline to underground reserves in the 3B1 block under the valley of Nolan Creek. The company started preparation of the Ogden/Eureka Bench and the West Block areas for openpit mining in 1995.

CoAL

Working with Hobbs Industries and the U.S. Bureau of Mines, Arctic Slope Consulting Group, a subsidiary of the Arctic Slope Regional Corporation, drove two declines at the Kuchiak Mine to demonstrate the viability of coal mining in permafrost. About 4,000 tons 
Table 6. Reported mineral development expenditures in Alaska by commodity, 1982-94

\begin{tabular}{|c|c|c|c|c|c|c|}
\hline & Base metals & Polymetallics & Precious metals & Industrial minerals & Coal and peat & TOTAL \\
\hline 1982 & $\$ 10,270,000$ & N/A & $\$ 19,320,000$ & $\$ 4,251,000$ & $\$ 7,750,000$ & \$ 41,591,000 \\
\hline 1983 & $19,500,000$ & N/A & $7,112,500$ & $1,000,000$ & 250,000 & $27,862,500$ \\
\hline 1984 & $10,710,500$ & N/A & $15,058,555$ & 579,000 & $27,000,000$ & $53,348,055$ \\
\hline 1985 & $13,000,000$ & N/A & $16,890,755$ & $1,830,000$ & $2,400,000$ & $34,120,755$ \\
\hline 1986 & $3,260,800$ & $8,000,000$ & $12,417,172$ & 124,000 & 530,000 & $24,331,972$ \\
\hline 1987 & $38,080,000$ & $48,000,000$ & $13,640,848$ & 188,000 & 342,000 & $100,250,848$ \\
\hline 1988 & $165,500,000$ & $69,000,000$ & $40,445,400$ & - & - & $274,945,400$ \\
\hline 1989 & $118,200,000$ & 411,000 & $6,465,350$ & $7,000,000$ & $2,196,000$ & $134,272,350$ \\
\hline 1990 & $\quad \cdots$ & $4,101,000$ & $7,136,500$ & 30,000 & $3,079,000$ & $14,346,500$ \\
\hline 1991 & - & $8,000,000$ & $14,994,350$ & 262,000 & $2,318,000$ & $25,574,350$ \\
\hline 1992 & 80,000 & $4,300,000$ & $23,151,300$ & 404,000 & $1,655,000$ & $29,590,300$ \\
\hline 1993 & .. & $10,731,136$ & $15,103,000$ & 433,500 & $1,400,000$ & $27,667,636$ \\
\hline 1994 & $10,000,000$ & $5,000,000$ & $27,392,850$ & 5,000 & $2,545,000$ & $44,942,850$ \\
\hline TOTAL & $\$ 388,601,300$ & $\$ 157,543,136$ & $\$ 219,128,580$ & $\$ 16,106,500$ & $\$ 51,465,000$ & $\$ 832,844,516$ \\
\hline
\end{tabular}

N/A Figures not available prior to 1986.

- Not reported.

Table 7. Reported mineral development expenditures and employment in Alaska, 1994

\begin{tabular}{|c|c|c|c|c|c|c|c|c|}
\hline & Northern & Western & $\begin{array}{l}\text { Eastern } \\
\text { interior }\end{array}$ & $\begin{array}{l}\text { South- } \\
\text { central }\end{array}$ & $\begin{array}{l}\text { South- } \\
\text { western }\end{array}$ & $\begin{array}{c}\text { Alaska } \\
\text { Peninsula }\end{array}$ & $\begin{array}{l}\text { South- } \\
\text { eastern }\end{array}$ & Total \\
\hline \multicolumn{9}{|c|}{ Development expenditures } \\
\hline Base metals & $10,000,000$ & -. & $\cdots$ & - & - & -- & $\ldots$ & $10,000,000$ \\
\hline Polymetallic & - & $-\cdot$ & - & - & $\cdots$ & - & $5,000,000$ & $5,000,000$ \\
\hline \multicolumn{9}{|l|}{ Precious metals } \\
\hline Placer & $1,000,000$ & 7,000 & 690,850 & 170,000 & 35,000 & -- & - & $1,902,850$ \\
\hline Lode & $\ldots$ & $3,500,000$ & $5,950,000$ & - & - & -- & $16,040,000$ & $25,490,000$ \\
\hline Coal and peat & $1,600,000$ & $\ldots$ & 120,000 & 825,000 & $\ldots$ & -- & $\ldots$ & $2,545,000$ \\
\hline Industrial minerals & $\ldots$ & $\cdots$ & 5,000 & - & $\cdots$ & $\cdots$ & -- & 5,000 \\
\hline Other & - & - & -- & -- & -- & $\cdots$ & $\cdots$ & $\cdots$ \\
\hline Total & $12,600,000$ & $3,507,000$ & $6,765,850$ & 995,000 & 35,000 & $\cdots$ & $21,040,000$ & $44,942,850$ \\
\hline \multicolumn{9}{|c|}{ Development employment } \\
\hline \multicolumn{9}{|l|}{ Employment } \\
\hline Workdays & 6,500 & 3,030 & 5,539 & 1,520 & 50 & - & 13,370 & 30,009 \\
\hline Workyears $^{\mathrm{a}}$ & 25 & 12 & 21 & 6 & 0 & - & 51 & 115 \\
\hline \multicolumn{9}{|c|}{ Number of companies } \\
\hline reporting ${ }^{b}$ & 2 & 2 & 14 & 5 & 2 & $\ldots$ & 4 & 29 \\
\hline
\end{tabular}

(3,631 tonnes) of coal were extracted during test mining with a continuous miner (fig. 12). The coal will be used in local villages as an alternate source of heat. Ongoing transportation studies continue to examine the economic feasibility of exporting coal from northwest Alaska to Pacific Rim and other markets.

\section{WESTERN REGION}

Reported development expenditures in the western region in 1994 were $\$ 3.5$ million, more than double the $\$ 1.6$ million reported in 1993. All development was related to precious metal projects. 


\section{Metals}

Alaska Gold Co. continued stripping overburden on its reserves near Nome in preparation for the conversion from dredge production to conventional openpit mining. Dredge 6's last year of operation was 1994. Dredge 5 will probably operate in 1995.

Consolidated Nevada Goldfields Inc. drove two 10-by-11-foot (3-by-3.3-meter) declines and cross cuts to provide access to the Crystal and Mystery zones of the gold-copper skarn orebody at the Nixon Fork Mine. Plans call for moving equipment into the area during the winter of 1994-95, building the mine in 1995 and producing gold by the end of the year. The mine is forecast to produce 60,000 ounces $(1,866$ kilograms) of gold per year for several years (fig. 13).

USMX Inc. began a mine feasibility study for the Illinois Creek gold-silver deposit near Nulato on the Yukon River, and propose to bring in the equipment overland from the river in the winter of 1995-96 or the following year, depending upon the permitting requirements. Plans call for a mining rate of about 34,000 tons $(30,845$ tonnes) per day to produce about 50,000 ounces $(1,555$ kilograms) of gold per year.

Sphinx Natural Resources, working with Malvy Technology Inc., reported some stripping of overburden at the mine on Monument Creek in the Ruby-Poorman area.

\section{EASTERN INTERIOR REGION}

Mineral development expenditures in 1994 were $\$ 6.77$ million, a decrease of 24 percent from the $\$ 8.92$ million invested for development in 1993.

\section{Metals}

The largest development project in Alaska's eastern interior region and in the entire United States (Thomas, 1995) was the engineering, design work, and clearing

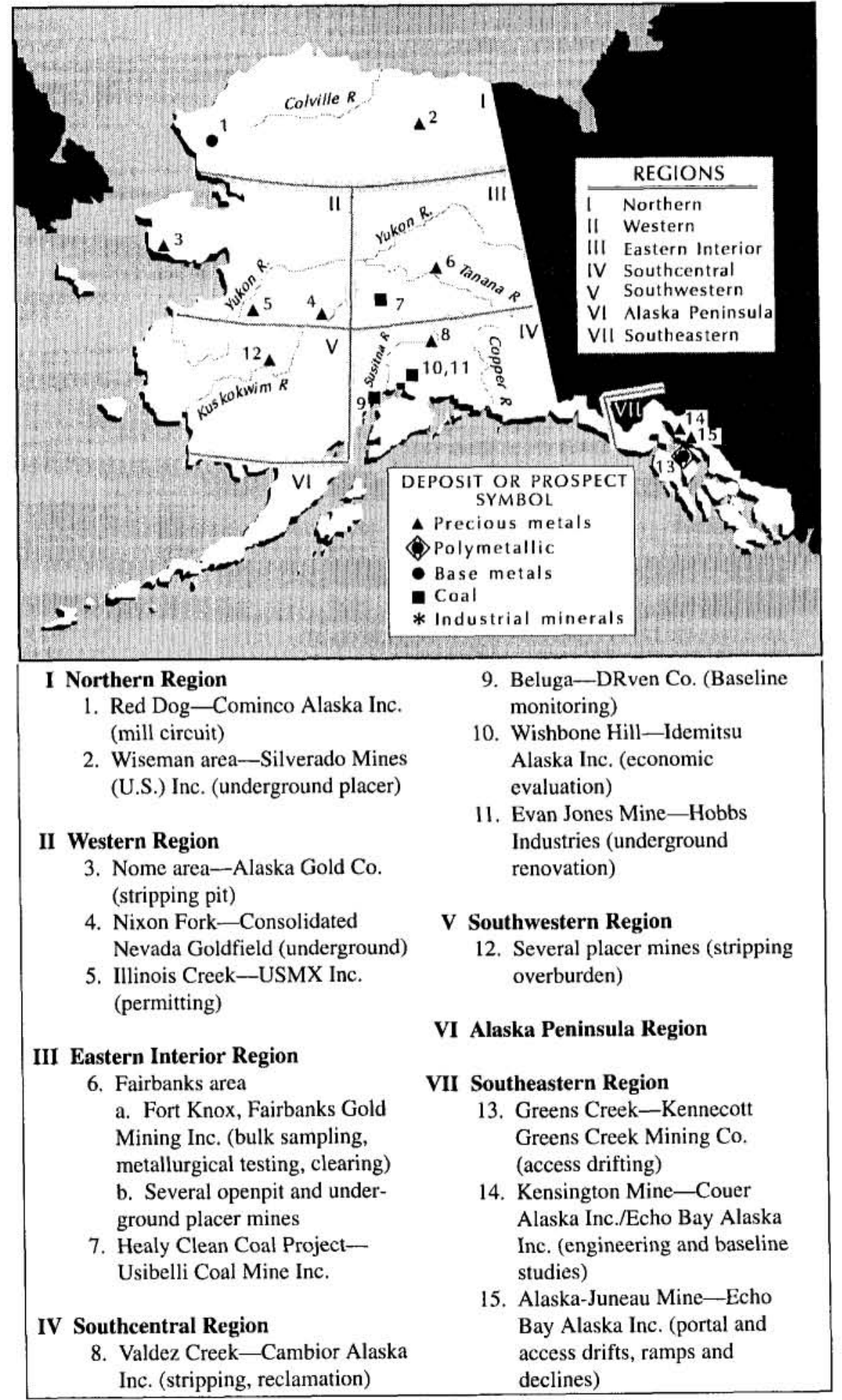

Figure 10. Selected mineral development projects in Alaska, 1994. 
by Fairbanks Gold Mining Co. at its Fort Knox Mine. Most of the state permits were in hand by February 1994, followed by the U.S. Army Corps of Engineers wetland (Sect 404 of the Clean Water Act) permit in May. This final permit acquisition, the last of a total of 41 , makes it possible for mine development to commence.

During the second and third quarters of the year the project was subject to a significant internal review, and in October the engineering contract was let to Ford, Bacon and Davis Inc. of Salt Lake City. Also in October, Fairbanks Gold applied for an air quality permit which was issued in 1995 .

By year end the ground clearing for the freshwater reservoir, the tailings impoundment, the millsite, and the access roads had all been completed. Early in 1995 Morrison-Knutsen Co. was selected as general contractor, and Kiewit Pacific Co. was subcontracted to complete the earthwork.

Several placer mines throughout the district reported development. In the Fairbanks district the Hopen Operation stripped overburden on Cleary and Little Eldorado Creeks. At the mouth of that creek the Little Eldorado Group advanced 700 feet ( 213 meters) of decline to reach the deeply buried gold placer deposit. Sam Skidmore reported development at his underground operation on Vault Creek. Polar Mining stripped frozen overburden at its year-round mine in the Lower Goldstream Valley. Yellow Eagle Mining began permitting and development of its operation near Ester. Herning Exploration and Mining prepared ground for mining on Palmer Creek in the Upper Chena drainage.

Delima Placers had a busy season doing roadwork and stripping at its operation on American Creek near

Figure 11. Ed Armstrong of Silverado Mines Inc. inspects a reclaimed mine area of Thompson's Pup in the Koyukuk-Nolan district of northern Alaska. Alaska's placer mining companies now reclaim opencut mines, access trails, and other disturbed mining areas in compliance with state and federal regulations. (Photo by Dick Swainbank)

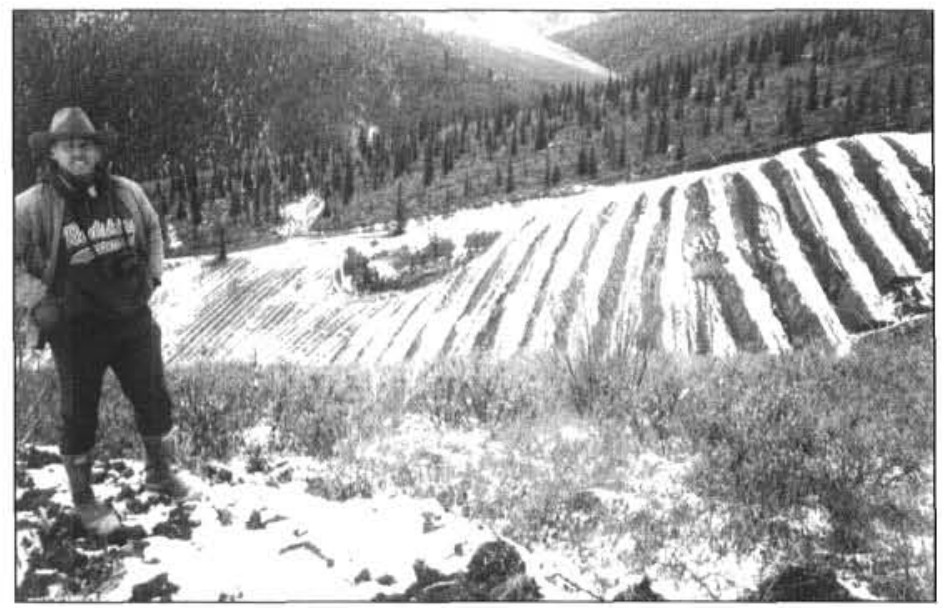

Figure 12. Joy 12 CM-5 continuous miner outside entry of the Kuchiak Research Mine. Nine feet (2.7 meters) of the 15 -foot (4.6 meter) K3 seam is exposed in this photo. (Photo by Mike Belowich)

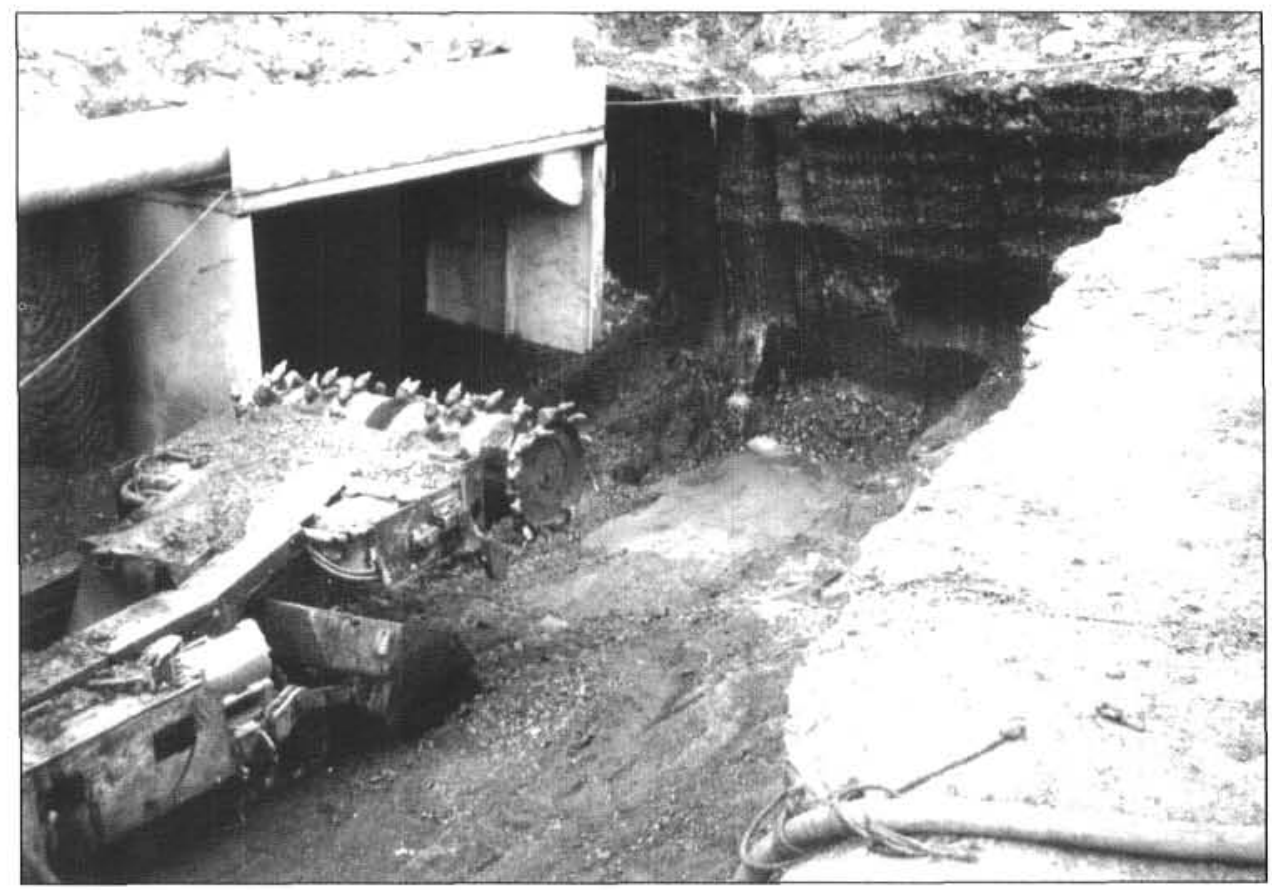


Manley. BDH Mining reported stripping on the North Fork of Twelvemile Creek near Circle. Busby Mining removed overburden at Lost Chicken Creek. FortyfivePup Mining stripped the creek of the same name in the Fortymile district.

\section{CoAl}

Usibelli Coal Mine Inc. used auger-drilling to develop reserves at the Two Bull Ridge area near its existing operations near Healy.

The Healy Clean Coal Project received approval of all permits by mid-1994, and construction under the management of H.C. Price Co. will begin in 1995. This 50-megawatt plant will be adjacent to the existing 25 megawatt mine-mouth plant, but will emit less than half the amount of oxides of sulfur and nitrogen than the existing plant, despite its using coal of lower quality.

In a related development. the State appropriated the funds to upgrade the electrical intertie between Healy and Fairbanks to allow more efficient distribution of power. Golden Valley Electric Association, the local electrical cooperative with headquarters in Fairbanks, received the first shipment of power poles for the 32 mile (51-kilometer) transmission line to the Fort Knox Mine about 15 miles ( 24 kilometers) northeast of Fairbanks. When it is in full operation Fort Knox will use about 35 megawatts of power.

\section{SOUTHCENTRAL REGION}

Development investment in southcentral Alaska in 1994 was $\$ 995,000$, less than 20 percent of the 1993 amount, which was reported as $\$ 5.56$ million. Most of the 1993 development was done by the Valdez Creek Mine, which is scheduled for closure in 1995. Most of the 1994 expenditure was for coal development.

\section{Metals}

Empire Exploration reported some development of its placer ground near Yentna, and several operations noted some stripping, road building or movement of equipment.

\section{COAL}

DRven Corporation did some environmental baseline monitoring at the Diamond Chuitna Project, and Idemitsu-Alaska Inc. had reported evaluating the economics of the Wishbone Hill deposit. Hobbs Industries continued work that they had started the previous year at the Evan Jones Mine. A decline designed to undercut a caved portion of the seam was driven about 400 feet (122 meters) in 1993 but was too steep for the equipment and had collapsed by 1994. The decision was made to rehabilitate a crosscut tunnel which had been used as access to the Number 3 seam from 1925 to

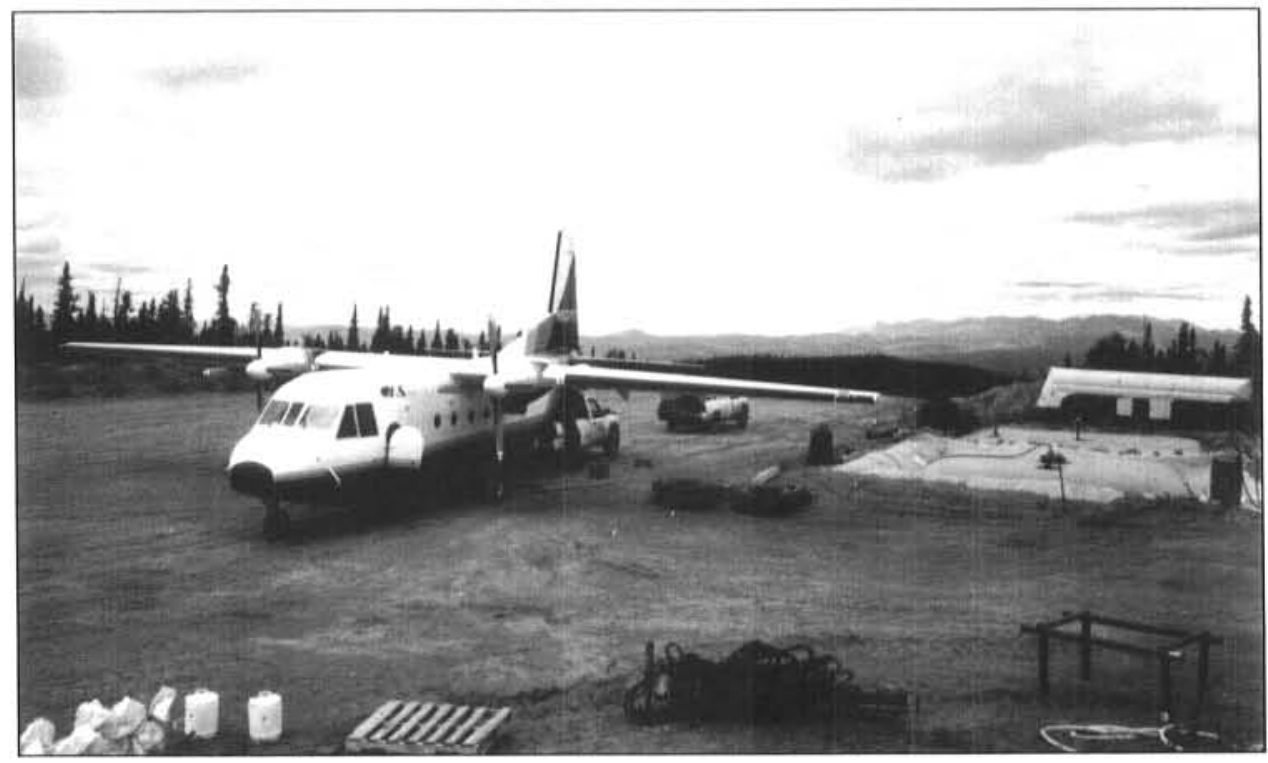

Figure 13. F.S. Air Service of Anchorage unloads Casa aircraft at the Nixon Fork copper-gold project about 35 miles (50 kilometers) northeast of McGrath in western Alaska. During mine development the modern underground operation has been supplied mainly by aircraft. Gold-copper production is expected to begin in the fall of 1995. Ore concentrates will be flown out with DC-6 aircraft. (Photo by Richard Flanders) 
1959. The first 300 feet (91 meters) of the 7-by-13-foot (2-by-4-meter) tunnel is through landslide deposits and requires intensive roof support. This work will continue in 1995. Reclamation of older work has been continuous throughout the process (fig. 14).

\section{SOUTHWESTERN REGION}

\section{Metals}

Only $\$ 35,000$ in development expenditures was reported in 1994, and all of the activity consisted of stripping overburden at gold placer mines. Paul Sayer reported a small amount of stripping at the Little Creek Mine, and Lyman Resources of Alaska reported stripping on Ruby and Queen Creeks in the Aniak district.

\section{SOUTHEASTERN REGION}

Mineral development investment in southeast Alaska, reported to be $\$ 21.04$ million in 1994 , was up dramatically over the $\$ 557,636$ reported in 1993 . Large advanced-exploration projects of prior years, such as that at the A-J Mine or Kensington Mine, switched to mine-development activity. This switch accounts for most of the increase in development expenditure between 1993 and 1994.

\section{Metals}

Echo Bay Alaska continued with development of its A-J Mine near Juneau in 1994, converting the Sheep Creek rail portal and adit for trackless mining, strengthening the portal area and providing avalanche protection, driving ramps and declines within the existing reserve areas, and driving exploration drifts for future access.

The main effort in 1994 was in permitting. The mine has a completed Environmental Impact Statement and Large-Mine Permit from the City and Borough of Juneau. Alaska Coastal Zone Consistency authorizations are in progress.

At year-end the federal Environmental Protection Agency (EPA) issued a Technical Assistance Report (TAR) for the U.S. Army Corps of Engineers to assist the Corps in its decision whether to allow Echo Bay to build a tailings dam for the A-J Mine in Sheep Creek. According to EPA news release (December 30, 1994) the report concluded, "There seems to be no way to avoid harm to water quality or to offset the loss of wildlife habitat from the proposed reopening of the Alaska-Juneau gold mine."

Rather than contest conclusions in the TAR, Echo Bay has announced that it will be seeking project changes that will satisfy the EPA. Of great significance to the project, in May 1995, during preparation of this report, the EPA announced that it would investigate the

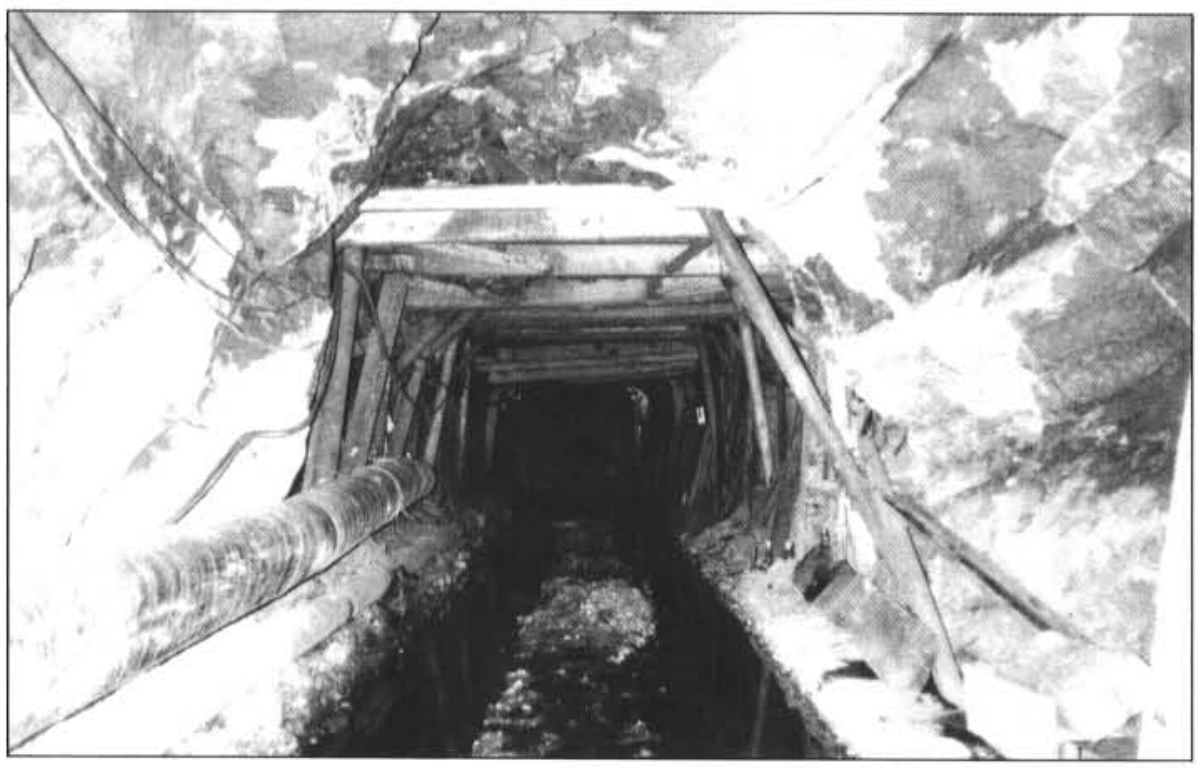

Figure 14. Lower crosscut tunnel accesses coal seams at the Evan Jones Mine about 20 miles (32 kilometers) northeast of Palmer in southcentral Alaska. Formely the Evan Jones mine produced coal for steam heat and electric power. Hobbs Industries continued development of high quality bitiminous coal resources in the Evan Jones Mine and continued research of both domestic and export market possibilities. (Photo by Mike Belowich) 
merits of submarine tailings disposal (STD) for the A-J project. The EPA had previously maintained that it would not examine or permit this alternative, even though many experts had asserted that STD was the most environmentally benign option for the project.

At the Kensington Mine, 50 miles ( 80 kilometers) north of Juneau, Echo Bay had a fifty-fifty joint-venture with Coeur Alaska Inc. in which Echo Bay was the operator. As at the A-J, the 1994 work entailed obtaining the permits to develop the mine. The project has a complete Environmental Impact Statement, a Large Mine Permit from the City and Borough of Juneau, and a preliminary Coastal Zone Consistency Determination from the state. The Kensington project was also the subject of an EPA Technical Assistance Report for the Corps of Engineers, which dealt mainly with water quality issues related to the tailings impoundment and effluent discharge into the marine environment. The report issued in December 1994, found the project deficient in six areas, mainly related to tailings storage and effluent discharge. The EPA suggested operational changes to address its concerns, and the joint-venture has since made suggested project modifications.

During the preparation of this report (May 1995) Coeur Alaska made an offer of a $\$ 32.5$ million cash payment for Echo Bay's 50 percent of the Kensington project. In addition to the cash payment the agreement is subject to a scaled royalty payment to Echo Bay on the first million ounces of Kensington gold production. The royalty ranges from one percent at a gold price of $\$ 400$ per ounce ( $\$ 14$ per gram) to a maximum of 2.5 percent at a price of $\$ 475$ per ounce ( $\$ 16.63$ per gram).

The various boards of the companies have agreed in principle to this arrangement, which will give Coeur Alaska Inc. 100 percent ownership of the Kensington Mine. Proven and probable reserves are estimated as 13.6 million tons (12.3 million tonnes) grading 0.143 ounces per ton (4.9 grams per tonne) of gold, or 1.95 million ounces $(60,658$ kilograms) of contained gold.

Kennecott Greens Creek Mining Company and partner Hecla Mining Company reported that about 70 people were employed at the minesite during 1994 , driving about 4,700 feet $(1,433$ meters $)$ of drifts to facilitate drilling and sampling. A preliminary feasibility study was also completed, which incorporates the reserves in the new southwest Alaska orebody.

Work scheduled for 1995 includes rebuilding the shiploader, rebuilding and expanding the concentrator shed, various water diversion projects, and redesign of the coarse-ore pad and tailings disposal areas. About 20,000 feet ( 6,096 meters) of drifting and 1,200 vertical feet ( 366 meters) of spiral ramp will be required to access the southwest ore. In May 1995 the Greens Creek Joint Venture announced that the mine would reopen in late 1996 or early 1997.

Snow Lion Mining reported some development activity at its mine on Cahoon Creek, a tributary to Porcupine Creek.

\section{PRODUCTION}

The value of Alaska's mineral production for 1994 is estimated at $\$ 507.5$ million, an increase of $\$ 58.8 \mathrm{mil}$ lion, which is 13.1 percent above 1993 levels (table 8). Total gross values for individual commodities are zinc, 58 percent; gold, 14 percent; sand and gravel, 8 percent; coal, 7 percent; building stone, 5 percent; lead, 5 percent; silver, 2 percent; and all other commodities including platinum, jade, and peat, 1 percent. Figures 15,16 , and 17 graph the gold, sand and gravel, and coal production, three important components of Alaska's mineral industry.

The authors of this report compiled the mineral production statistics from data supplied by 244 placer gold, coal, lode metallic, and industrial mineral mines and quarries that operated in all seven regions of the state. Selected mine sites in each geographic region are shown in figure 18. Mineral production estimates were derived from: (1) data from 196 DGGS mineral questionnaires (as of May 31, 1995) returned by Native corporations, mining companies, individuals, and government agencies; (2) a phone survey of selected metal, industrial mineral and recycling firms; (3) from Alaska Placer Mining Application (APMA) records supplied by the Division of Mining \& Water Management; and (4) from regional materials-use summaries supplied to DGGS by the Alaska Department of Transportation and Public Facilities, the U.S. Bureau of Land Management, and the U.S. Forest Service.

Thirty-one percent of the industrial mineral producers and all energy-mineral respondents provided unit values for many mineral commodities. We compute unit value of metals by averaging 12 monthly commodity prices that were published in the Mining Journal Ltd. with production information from other mining publications. Hence, value estimates for each metal listed in table 8 do not take into account transportation, refining or other financial costs incurred during the mining process.

As in 1993, metals again dominated Alaska mineral production and accounted for 79 percent of the 1994 mineral product value. Increased metal output-both volume and value - accounted for practically all the 
Table 8. Estimated mineral production in Alaska, 1992-94a

\begin{tabular}{|c|c|c|c|c|c|c|c|c|c|}
\hline \multirow[b]{2}{*}{ Metals } & \multicolumn{3}{|c|}{ Quantity } & \multicolumn{6}{|c|}{ Estimated values $^{b}$} \\
\hline & 1992 & 1993 & 1994 & & 1992 & & 1993 & & 1994 \\
\hline $\begin{array}{l}\text { Gold (ounces) } \\
\text { (kilograms) }\end{array}$ & $\begin{array}{r}262,530 \\
8,163\end{array}$ & $\begin{array}{r}191,265 \\
5,948\end{array}$ & $\begin{array}{r}182,100 \\
5,663\end{array}$ & $\$$ & $88,463,000$ & $\$$ & $68,640,800$ & & $70,290,600$ \\
\hline $\begin{array}{l}\text { Silver (ounces) } \\
\text { (kilograms) }\end{array}$ & $\begin{array}{r}9,115,755 \\
283,500\end{array}$ & $\begin{array}{r}5,658,958 \\
175,994\end{array}$ & $\begin{array}{r}1,968,000 \\
61,205\end{array}$ & & $34,913,341$ & & $24,333,519$ & & $10,391,040$ \\
\hline $\begin{array}{l}\text { Platinum (ounces) } \\
\text { (grams) }\end{array}$ & $\begin{array}{l}\text { W } \\
\text { W }\end{array}$ & $\begin{array}{r}3 \\
95\end{array}$ & $\begin{array}{r}5 \\
158\end{array}$ & & W & & 1,235 & & 2,065 \\
\hline $\begin{array}{l}\text { Lead (tons) } \\
\text { (tonnes) }\end{array}$ & $\begin{array}{l}68,664 \\
62,278\end{array}$ & $\begin{array}{l}38,221 \\
34,667\end{array}$ & $\begin{array}{l}36,447 \\
33,065\end{array}$ & & $31,585,440$ & & $13,759,560$ & & $25,512,900$ \\
\hline $\begin{array}{l}\text { Zinc (tons) } \\
\text { (tonnes) }\end{array}$ & $\begin{array}{l}274,507 \\
248,978\end{array}$ & $\begin{array}{l}268,769 \\
243,774\end{array}$ & $\begin{array}{l}329,003 \\
298,472\end{array}$ & & $301,957,700$ & & $236,516,720$ & & $296,102,700$ \\
\hline $\begin{array}{r}\text { Tin (pounds) } \\
\text { (kilograms) }\end{array}$ & $\begin{array}{r}1,500 \\
680\end{array}$ & $\begin{array}{r}21,000 \\
9,526\end{array}$ & $\begin{array}{l}\text { W } \\
\text { W }\end{array}$ & & 5,910 & & 50,610 & & W \\
\hline Subtotal & & & & & $456,925,391$ & & $343,302,444$ & & $402,299,305$ \\
\hline \multicolumn{10}{|l|}{ Industrial minerals } \\
\hline $\begin{array}{l}\text { Jade and soapstone (tons) } \\
\text { (tonnes) }\end{array}$ & $\begin{array}{l}1.5 \\
1.4\end{array}$ & $\begin{array}{l}2.6 \\
2.4\end{array}$ & $\begin{array}{l}2.3 \\
2.1\end{array}$ & $\$$ & 30,000 & $\$$ & 20,000 & $\$$ & 20,000 \\
\hline $\begin{array}{l}\text { Sand and gravel (million to } \\
\text { (million tonnes) }\end{array}$ & tons) $\begin{array}{r}14.6 \\
13.2\end{array}$ & $\begin{array}{l}13.2 \\
11.9\end{array}$ & $\begin{array}{l}13.5 \\
12.3\end{array}$ & & $42,200,000$ & & $40,636,815$ & & $40,950,651$ \\
\hline $\begin{array}{l}\text { Building stone (million ton } \\
\text { (million tonnes) }\end{array}$ & $\begin{array}{l}2.9 \\
2.6\end{array}$ & $\begin{array}{l}3.6 \\
3.3\end{array}$ & $\begin{array}{l}3.8 \\
3.5\end{array}$ & & $22,971,000$ & & $26,205,784$ & & $27,038,008$ \\
\hline Subtotal & & & & & $65,201,000$ & & $\$ 66,862,599$ & & $\$ 68,008,659$ \\
\hline \multicolumn{10}{|l|}{ Energy minerals } \\
\hline $\begin{array}{l}\text { Coal (tons) } \\
\text { (tonnes) }\end{array}$ & $\begin{array}{l}1,531,800 \\
1,389,340\end{array}$ & $\begin{array}{l}1,586,795 \\
1,439,223\end{array}$ & $\begin{array}{l}1,490,000 \\
1,351,730\end{array}$ & $\$$ & $38,300,000$ & $\$$ & $38,103,600$ & $\$$ & $36,750,000$ \\
\hline $\begin{array}{l}\text { Peat (cubic yards) } \\
\text { (cubic meters) }\end{array}$ & $\begin{array}{l}70,000 \\
53,552\end{array}$ & $\begin{array}{l}72,000 \\
55,051\end{array}$ & $\begin{array}{l}87,900 \\
67,208\end{array}$ & & 400,000 & & 445,000 & & 439,500 \\
\hline Subtotal & & & & $\$$ & $38,700,000$ & $\$$ & $38,548,600$ & $\$$ & $37,189,500$ \\
\hline TOTAL & & & & & $560,826,391$ & & $448,713,643$ & & $507,497,464$ \\
\hline
\end{tabular}

aproduction data from DGGS questionnaires, USBM file data (for 1991), phone interviews with mine operators and land owners, Alaska Department of Transportation and Public Facilities, and other sources.

${ }^{b}$ Values for selected metal production based on average prices for each year; for 1994 -gold (\$386/ounce); silver ( $\$ 5.41 /$ ounce); zinc $(\$ 0.45 / \mathrm{lb})$; lead $(\$ 0.35 / \mathrm{lb})$; platinum $(\$ 413 /$ ounce). All other values provided by mine operators.

$\mathrm{W}=$ Withheld.

13 percent increase in mineral production from 1993 to 1994. Metal values increased from $\$ 343.3$ million in 1993 to $\$ 402.3$ million in 1994 , an increase of 17 percent, due mainly to zinc output from the Red Dog Mine. In fact, the 329,003 tons $(298,472$ tonnes) of zinc that made its way to international markets from the Red Dog project accounted for 59 percent of all the mine-produced zinc in the United States and about 6.5 percent of the world's mine-produced zinc. This level of production firmly established Cominco's mine as one of the world's major metal-commodity players.
Alaska silver production fell from 5.66 million ounces (176 tonnes) in 1993 to 1.97 million ounces (61 tonnes) in 1994, a reduction of 65 percent. This sharp decline in Alaska silver output was caused by the closing of the polymetallic Greens Creek Mine on Admiralty Island in southeastern Alaska and by reduced silver recovery from concentrates shipped from the polymetallic Red Dog Mine. In the next few years the Red Dog Mine, and possibly the Greens Creek Mine, and the state's placer gold mines will proceed with silver recovery. The Greens Creek Mine, which closed in 1993, may reopen in 1997. 


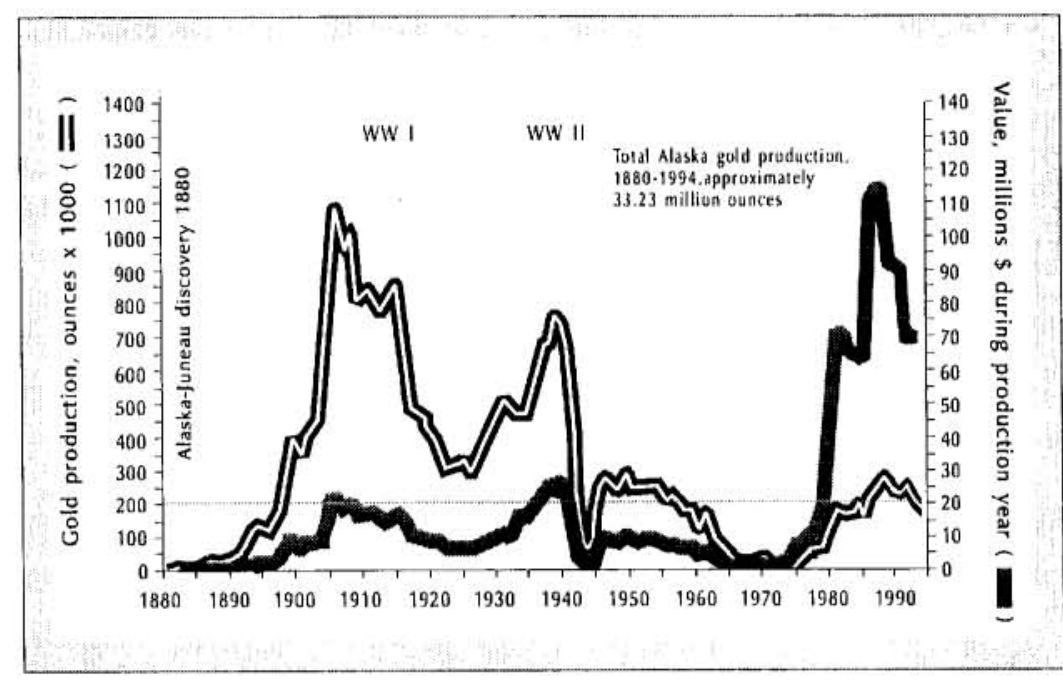

Figure 15. Amount and value of gold production in Alaska, 1880-1994.

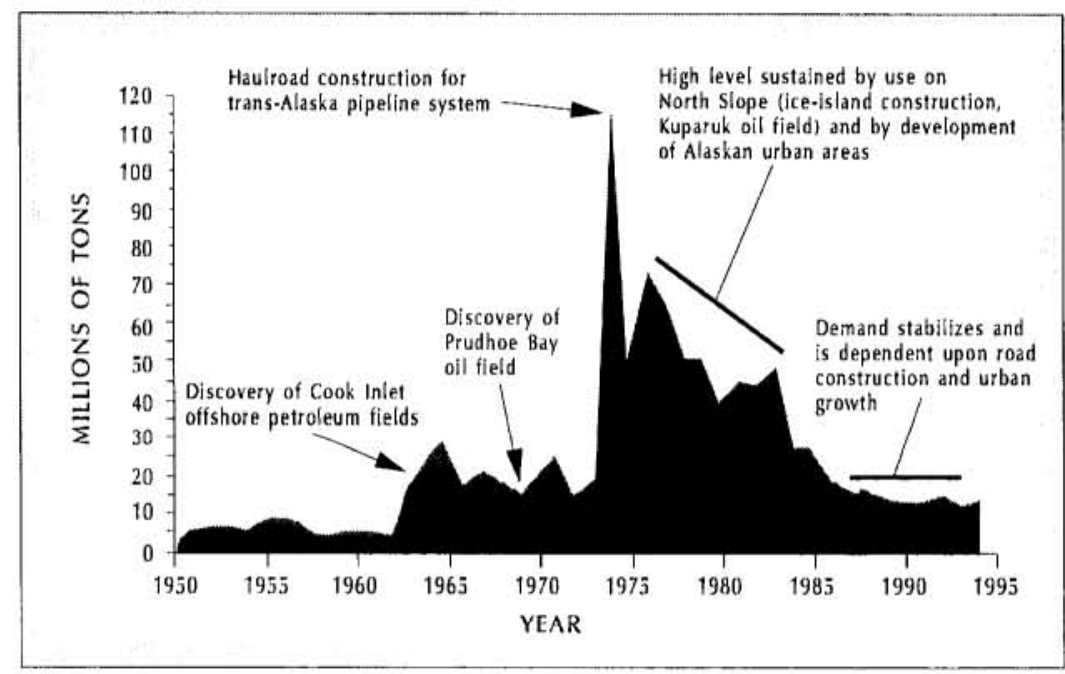

Figure 16. Sand and gravel production in Alaska, 1950-94.

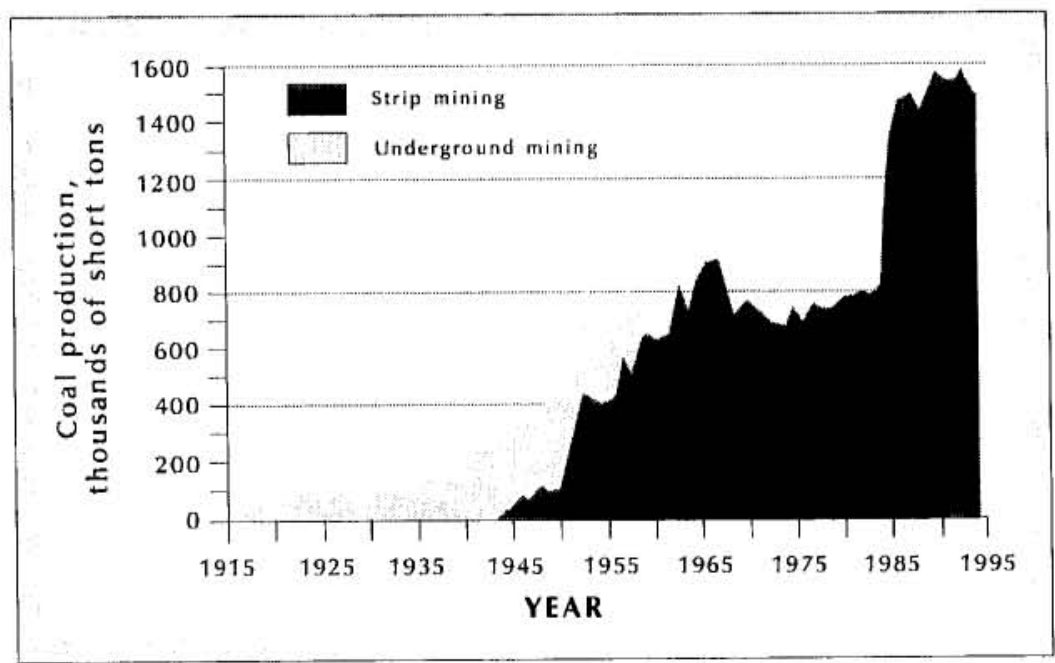

Figure 17. Coal production in Alaska, 1915-94.
In 1994 Alaska's mines produced an estimated 182,100 ounces $(5,663$ kilograms $)$ of refined ${ }^{6}$ gold worth $\$ 70.3$ million from 182 placer mines in 1994, compared with 191,265 ounces $(5,948$ kilograms) of gold worth $\$ 68.6$ million that was produced from 196 placer and one lode mine in 1993 (table 9). An 8 percent decline in the number of placer mines caused the 5 percent decline in gold production. The closing of the Greens Creek polymetallic mine also contributed to the overall decline in Alaska gold production. However, gold price increases actually resulted in a 2 percent rise in the value of gold mining from 1993 to 1994.

Large placer mines traded production ranking in gold output, but there has been a slow but steady decline in the number of small-to-medium sized placer operations in eastern interior, southcentral, and southwestern regions of the state. In addition, the announced 1995 closure of Cambior Alaska's Valdez Creek Mine in southcentral Alaska and expected shutdowns of other large placer operations in the next few years unfortunately will cause further production losses in the placer industry.

Despite these declines, placer mining continues to be a small-business-oriented industry that supplies many jobs in remote rural Alaska. With anticipated hardrock gold production from the Nixon Fork copper-gold skarn deposit in 1995, the Fort Knox porphyry gold deposit in 1996, and possibly the Illinois Creek silver-gold deposit in 1997, overall Alaska gold output should begin to rise again in the near future.

During 1994, every region of Alaska except the Alaska Peninsula reported gold production (table 9). Cambior's Valdez Creek Mine again topped the list with 47,622 ounces (1,481 kilograms) of gold, or 26 percent of the entire state's production.

${ }^{6}$ Throughout this report production quantities refer to refined gold unless stated otherwise. 
Rounding out the top ten producers were Polar Mining Inc. on Lower Goldstream near Fairbanks; Alaska Gold Company near Nome; Silverado Mines in the Wiseman area; Alaska Placer Development near Livengood; Polar Mining Inc. on Fish Creek near Fairbanks; Nyac Mining Company south of Aniak; Cooks Mining near Fairbanks; Sphinx Natural Resources near Ruby; and Little Eldorado Group also near Fairbanks. These operations produced 104,222 ounces (3,241 kilograms) of gold or 57.5 percent of the statewide total. In previous years the ten top gold producers have accounted for 60 percent (1992), 57 percent (1991), 49 percent (1990), 61 percent (1989), 59 percent (1988), and 58 percent (1987) of statewide totals.

Operators cited fuel cost increases, equipment breakdowns, and decreasing gold grades as factors that increased mine costs in 1994. In 1994, the average cost to produce an ounce of Alaska gold was $\$ 343$ (\$11.00 per gram) up from $\$ 300$ ( $\$ 9.60$ per gram) in 1993. Table 10 shows unit-cost figures from 172 Alaska placer mines that have responded to the DGGS questionnaire for the six years represented in the table. These 172 mines constitute 14 percent of the total 1,210 mines have been active during this time. The gold output of 506,087 ounces $(15,739$ kilograms) reported to us amounts to 41 percent of the total $1,239,543$ ounces $(38,549$ kilograms $)$ of placer gold produced in Alaska during the six years for which we have data (Bundtzen and others, 1994, table 11).

Alaska industrial mineral output totaled about $\$ 68$ million

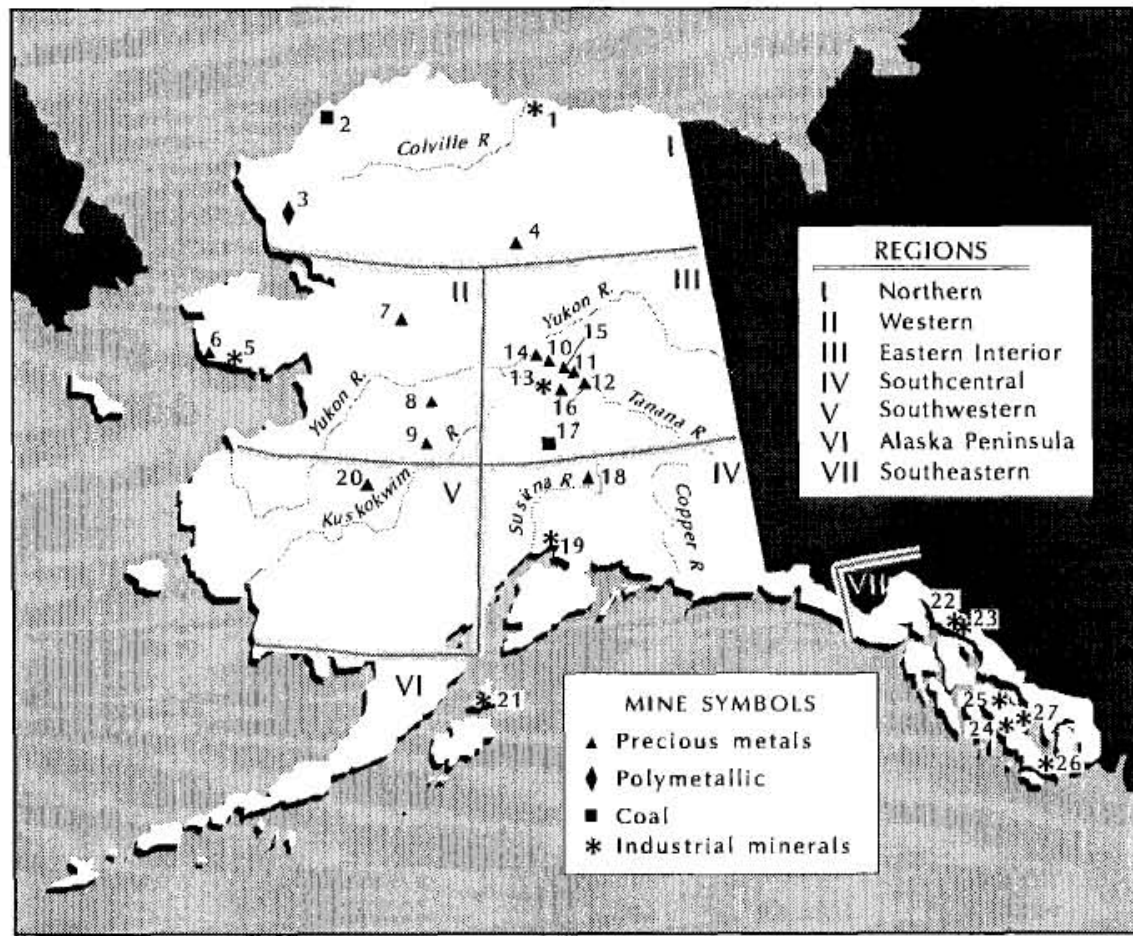

I Northern Region

1. Sagavanirktok River-gravel

2. Kuchiak Mine-coal

3. Red Dog Mine-lead-zinc-silver

4. Silverado U.S. Inc. mines-gold

Metallic mines

11

Industrial mineral producers

3

\section{Western Region}

5. Cape Nome Quarry—rock, sand and gravel

6. Alaska Gold Co.--gold

7. Taiga Mining/Hogatza-gold

8. Green Mining and Explorationgold

9. Rosander Mining Co.- gold

Metallic mines $\quad 34$

Industrial mineral producers

5

10. Alaska Placer Development-gold

11. Polar Mining Inc.- - gold

12. Earthmovers - gravel

13. Thurman Oil \& Mining--gold

14. Little Eldorado Group-gold

15. Paul and Company - gold

16. Cooks Mining-gold

17. Usibelli Coal Mining Inc.-coal

Metallic mines 112

Industrial mineral producers 17
III Eastern Interior Region
IV Southcentral Region

18. Valdez Creek Mine-gold

19. Palmer/Wasilla area-gravel pits

Metallic mines 20

Industrial mineral producers

V Southwestern Region

20. Nyac Mining Co.-gold

Metallic mines

18

Industrial mineral producers

VI Alaska Peninsula Region

Metallic mines 0

Industrial mineral producers

2

21. Red Samm Constructiongravel

VII Southeastern Region

22. Hildre Sand and Gravelgravel

23. Greens Creek Mine-zinc, silver, gold, lead

24. U.S. Forest Service-rock, sand and gravel

25. Sealaska Corporation-rock, sand and gravel

Metallic mines 3

Industrial mineral producers

15
Figure 18. Selected production projects, 1994. 
Table 9. Reported refined gold production, number of operators, and industry employment in Alaska, 1993-94

\begin{tabular}{|c|c|c|c|c|c|c|}
\hline \multirow[t]{2}{*}{ Region } & \multicolumn{2}{|c|}{$\begin{array}{c}\text { Number of } \\
\text { operators }\end{array}$} & \multicolumn{2}{|c|}{$\begin{array}{l}\text { Production in } \\
\text { ounces of gold }\end{array}$} & \multicolumn{2}{|c|}{$\begin{array}{l}\text { Number of } \\
\text { employees }\end{array}$} \\
\hline & 1993 & 1994 & 1993 & 1994 & 1993 & 1994 \\
\hline Northern & 10 & 9 & $\begin{array}{r}5,254 \\
(164 \mathrm{~kg})\end{array}$ & $\begin{array}{r}10,292 \\
(320 \mathrm{~kg})\end{array}$ & 65 & 77 \\
\hline Western & 34 & 32 & $\begin{array}{r}49,733 \\
(1,547 \mathrm{~kg})\end{array}$ & $\begin{array}{r}42,783 \\
(1,374 \mathrm{~kg})\end{array}$ & 294 & 255 \\
\hline Eastern interior & 112 & 103 & $\begin{array}{r}77,233 \\
(2,402 \mathrm{~kg})\end{array}$ & $\begin{array}{r}69,511 \\
(2,161 \mathrm{~kg})\end{array}$ & 524 & 490 \\
\hline Southcentral & 20 & 19 & $\begin{array}{r}42,268 \\
(1,313 \mathrm{~kg})\end{array}$ & $\begin{array}{r}49,723 \\
(1,546 \mathrm{~kg})\end{array}$ & 240 & 238 \\
\hline Southwestern & 18 & 17 & $\begin{array}{r}9,254 \\
(288 \mathrm{~kg})\end{array}$ & $\begin{array}{r}9,650 \\
(300 \mathrm{~kg})\end{array}$ & 77 & 84 \\
\hline Southeastern & 3 & 2 & $\begin{array}{r}7,523 \\
(234 \mathrm{~kg})\end{array}$ & $\begin{array}{r}141 \\
(4 \mathrm{~kg})\end{array}$ & $45^{\mathrm{a}}$ & 6 \\
\hline TOTAL & 197 & 182 & $\begin{array}{r}191,265 \\
(5,948 \mathrm{~kg})\end{array}$ & $\begin{array}{r}182,100 \\
(5,663 \mathrm{~kg})\end{array}$ & 1,245 & 1,150 \\
\hline
\end{tabular}

${ }^{\mathrm{a}}$ Includes a percentage of employment from Greens Creek polymetallic mine. in 1994, about the same level as 1993 , but there were significant regional changes (tables 9, 11, and 12). Sand and gravel use increased in the northern and eastern interior regions, but decreased in the western, southwestern, and southeastern regions. Stone production also increased in the northern Alaska Peninsula and southeastern regions, but was down in the western, eastern interior, and southcentral areas of the state. Values of industrial minerals vary greatly and depend on location, type of material marketed, and availability, which explains the wide price ranges for the unit values for each commodity depicted in tables 11 and 12 .

Table 10. Production costs for selected Alaska placer gold mines, 1990-94

Mine size

Small $^{\mathrm{a}}$
Medium $^{\mathrm{b}}$
Large $^{\mathrm{c}}$

TOTAL

$\begin{array}{lr} & \\ \text { Small }^{\mathrm{a}} & 2,977 \\ \text { Medium }^{\mathrm{b}} & 6,461 \\ \text { Largec }^{\mathrm{c}} & 98,816 \\ \text { TOTAL } & \mathbf{1 0 8 , 2 5 4 ^ { d }} \\ & (\mathbf{3 , 3 5 9} \mathbf{~ k g})\end{array}$

Small ${ }^{\mathrm{a}}$

Medium $^{b}$

Large $^{c}$

$$
\begin{array}{r}
784,177 \\
1,538,000 \\
31,972,300
\end{array}
$$

TOTAL

$$
\$ 32,294,477
$$

1990

1991

1992

1993

1994

Number of mines

8

11
5

24

21
8
5
34

34
23

5

34

5

$\begin{array}{rr}19 & 24 \\ 4 & 6 \\ 2 & 4 \\ & \end{array}$

Production in ounces

1,856
12,132
54,497
$\mathbf{6 8 , 4 8 5}$
$(\mathbf{2 , 1 2 4} \mathbf{~ k g})$

3,582
8,431
84,539
$\mathbf{9 6 , 5 5 2}$
$\mathbf{( 3 , 0 0 2} \mathbf{~ k g})$

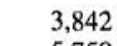

5,759

128,992

138,593g

$(4,310 \mathrm{~kg})$
25

Total reported mine cost in millions of dollars

$\begin{array}{rr}\$ 560,600 & \$ 1,018,606 \\ 3,314,000 & 2,518,239 \\ 18,990,000 & 31,857,228 \\ & \\ & \$ 35,394,073\end{array}$

$\$ 22,864,600$

$$
\begin{array}{r}
\$ 940,000 \\
1,460,000 \\
41,650,000
\end{array}
$$

$\$ 44,050,000$

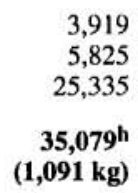

\begin{tabular}{|c|c|c|c|c|c|c|}
\hline Smalla & $\$ 263$ & $\$ 302$ & $\$ 284$ & $\$ 245$ & $\$ 263$ & $\$ 354$ \\
\hline Medium $^{\mathrm{b}}$ & 238 & 273 & 298 & 255 & 327 & 347 \\
\hline Large $^{c}$ & 324 & 348 & 376 & 322 & 300 & 341 \\
\hline TOTAL & $\$ 317$ & $\$ 334$ & $\$ 366$ & $\$ 318$ & $\$ 300$ & $\$ 343$ \\
\hline
\end{tabular}

2,789

7,471

48,864

$59,124^{i}$

$(1,839 \mathrm{~kg})$

Unit cost per ounce

${ }^{\mathrm{a}} 10-650 \mathrm{oz}$ gold/yr.

b $650-2,500 \mathrm{oz}$ gold/yr.

c $>2,500 \mathrm{oz}$ gold $/ \mathrm{yr}$.

$\mathrm{d}_{43}$ percent of total Alaskan placer gold production.

e 36 percent of total Alaskan placer gold production.

$\mathrm{f}_{46}$ percent of total Alaskan placer gold production.

$\mathrm{g}_{61}$ percent of total Alaskan placer gold production.

${ }^{h} 19$ percent of total Alaskan placer gold production.

i32 percent of total Alaskan placer gold production. 
Almost all coal production came from the Usibelli Mine at Healy in 1994. Production continued at levels of previous years. About 1.49 million tons ( 1.35 million tonnes) were produced for both domestic and export markets. Importantly, international coal prices began to improve late in 1994, which should greatly enhance the export markets for Usibelli coal.

\section{NORTHERN REGION}

\section{Metals}

Cominco Alaska, operator of the Red Dog Mine in northwest Alaska, mined and milled 2,339,500 tons $(2,121,900$ tonnes) of zinc-lead-silver ores, and produced 658,000 tons $(596,940$ tonnes) of zinc, lead, and bulk concentrates (table 13). A record 620,590 tons (563,000 tonnes) of polymetallic concentrates were shipped from the port of Kivalina to customers in Canada, Japan, South Korea, and Europe. Red Dog is owned by NANA Corporation (NANA) and operated by Cominco Alaska, the Alaska subsidiary of Canada-based Cominco Ltd. NANA is entitled to 4.5 percent of net-profits interest in Red Dog until Cominco recovers its interest and capital expenses. Then NANA's net profits entitlement is raised to 25 percent and increases by 5 percent each year until NANA's interest reaches 50 percent. Although Red Dog did not make a profit in 1994, it operated at a profit for the second half of the year. Improving economic performance at Red Dog was the result of larger zinc output coupled with stronger zinc prices (Ellis, 1995).

Concentrate production increased approximately 25 percent from 1993 to 1994 primarily by increasing the capacity of the grinding circuits in the mill. The $\$ 21$ million grinding-circuit improvement project was completed in the fall of 1994. Overall zinc recovery continued to increase although lead and silver recoveries dropped somewhat due to the oxidized nature of the mill-run ores. Installation of the new tower mill and additional diesel-generating capacity was also completed late in the year.

Cominco continued to work with the Alaska Department of Environmental Conservation and the Department of Fish and Game to reduce the amount of metals in ground water leached from the shallow orebodies at Red Dog. Cominco is temporarily containing the waters while it designs and tests treatment facilities.

Due to unfortunate early icing conditions encountered in the Beaufort Sea, the annual Red Dog fuel barge failed to reach Kivalina in October. As a result, bulk fuels had to be flown to the mine site during the 1994-95 winter season. Everts Fuel of Fairbanks won the contract for the fuel-haul. Cominco provided 311 full-time jobs during the year. Half the workers were
Table 11. Reported sand and gravel production and industry employment in Alaska by region, 1994

\begin{tabular}{|c|c|c|c|c|c|}
\hline Region & $\begin{array}{l}\text { Companies and } \\
\text { gencies reporting }\end{array}$ & Tons & 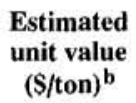 & $\begin{array}{l}\text { Total } \\
\text { value }\end{array}$ & $\begin{array}{l}\text { Estimated } \\
\text { number of } \\
\text { employees }\end{array}$ \\
\hline Northern & 4 & $1,101,250$ & $\$ 4.75$ & $\$ 5,230,938$ & 45 \\
\hline Western & 3 & 426,000 & 5.25 & $2,236,500$ & 20 \\
\hline Eastern Interior & 14 & $5,533,135$ & 2.60 & $14,386,151$ & 225 \\
\hline Southcentral & 9 & $5,562,516$ & 2.80 & $15,593,440$ & 263 \\
\hline Southwestern & 2 & 178,600 & 2.48 & 444,390 & 12 \\
\hline Alaska Peninsula & 2 & 113,400 & 2.50 & 283,500 & 10 \\
\hline Southeastern & 7 & 603,420 & 4.60 & $2,775,732$ & 65 \\
\hline TOTAL & $\begin{array}{l}41 \\
412,263,8\end{array}$ & $\begin{array}{l}13,518,321 \\
21 \text { tonnes) }\end{array}$ & $\$ 3.03$ & $\$ 40,950,651$ & 640 \\
\hline
\end{tabular}

${ }^{\text {a}}$ From 24 returned questionnaires and 17 phone canvas responses.

${ }^{b}$ Values are based on price and cost estimates from 12 producers (29\%) of the canvas and about 25 percent of the total product value.

Table 12. Reported stone production and industry employment in Alaska by region, $1994^{a}$

\begin{tabular}{|c|c|c|c|c|c|}
\hline Region & $\begin{array}{l}\text { Companies and } \\
\text { ggencies reporting } b\end{array}$ & Tons & $\begin{array}{c}\text { Estimated } \\
\text { unit value } \\
\text { (\$/ton) }^{\mathrm{c}}\end{array}$ & $\begin{array}{l}\text { Total } \\
\text { value }\end{array}$ & $\begin{array}{l}\text { Estimated } \\
\text { number of } \\
\text { employees }\end{array}$ \\
\hline Northern & 1 & 115,356 & $\$ 8.00$ & 922,848 & 5 \\
\hline Western & 1 & 65,000 & 15.00 & 975,000 & 25 \\
\hline Eastern Interior & 3 & 185,360 & 7.50 & $1,390,200$ & 25 \\
\hline Southcentral & 1 & 1,573 & 4.49 & 7,062 & 1 \\
\hline Southwestern & $\cdots$ & -. & - & -. & $\cdots$ \\
\hline Alaska Peninsula & 2 & 475,000 & 5.75 & $2,731,250$ & 30 \\
\hline Southeastern & 4 & $3,001,664$ & 7.00 & $21,011,648$ & 124 \\
\hline TOTAL & $12_{(3,487,23}$ & $\begin{array}{r}3,843,953 \\
34 \text { tonnes) }\end{array}$ & $\$ 7.03$ & $\$ 27,038,008$ & 210 \\
\hline
\end{tabular}

ancludes riprap, shot rock, crushed stone, and building (ornamental) stone; does not include jade. berived from 12 questionnaires.

${ }^{c}$ Unit value based on data supplied by five operations or 42 percent of the total. Unit values for different stone products can vary widely. 
NANA shareholders, and most of the rest commuted from other Alaska locations.

At the end of 1994, proven and probable reserves at Red Dog were 59.9 million tons (54.3 million tonnes) grading 5.5 percent lead, 18.3 percent zinc, and 2.71 ounces per ton (93 grams per tonne) of silver; an additional 15.5 million tons (14.1 million tonnes) grading 2.7 percent lead, 10 percent zinc, and 1.2 ounces per ton (41 grams per tonne) of silver are inferred. The nearby Hilltop orebody contains a resource of 8.8 million tons ( 8 million tonnes) grading 20 percent zinc, 6 percent lead, and 3.5 ounces per ton (120 grams per tonne) of silver.

State Alaska Placer Mining Application (APMA) records show that nine placer mines produced gold in the northern region and most of these were concentrated in the Wiseman area. An estimated 10,292 ounces (320 kilograms) of gold was produced in 1994, nearly twice the 5,254 ounces (164 kilograms) of gold produced in 1993 (table 9).

Silverado Mines (U.S.) Inc., during 1994, operated the largest gold mine in the northern region, and the fourth largest gold mine in Alaska. Silverado recovered 8,411 ounces ( 262 kilograms) of refined gold worth about $\$ 3.3$ million from both underground and openpit placer mines that were operated in tandem on a yearround basis.
The Marys Bench underground drift mine produced about 3,400 ounces ( 106 kilograms) of gold during the winter, and the Eureka openpit that operated in the summer produced most of the balance of the bullion. On August 24, nearly 800 ounces ( 25 kilograms) of gold were taken during 32 hours of sluicing from the Eureka bench deposits. Marys Bench underground workings produced a high-purity 41.35 ounce $(1,286$ gram) gold nugget that is unofficially the tenth largest recovered from Alaska's placer fields.

Silverado estimated that approximately 50,500 ounces (1,571 kilograms) of gold remained as mineable placer reserves at the end of 1994 . The two placer mines provided 14 full-time-equivalent jobs during the winter and summer mine operations. Silverado expects to achieve or exceed the established 1994 operational levels during the 1995 season.

Smaller placer mines operated in the Wiseman area. Compass Mining operated a small drift mine on Linda Creek. Slate Creek Mine worked a paystreak on Slate Creek near Coldfoot for 80 days. Gold Dust Mines operated for 139 days on two paystreaks owned by Little Squaw Gold Mining Company in the Chandalar district, east of Wiseman. B and B Mining was also active in the Chandalar area. Gold Dust worked much of the season on St. Marys Creek and a shorter time on Big Creek.

Table 13. Cominco Alaska's Red Dog Mine, production statistics, 1989-94

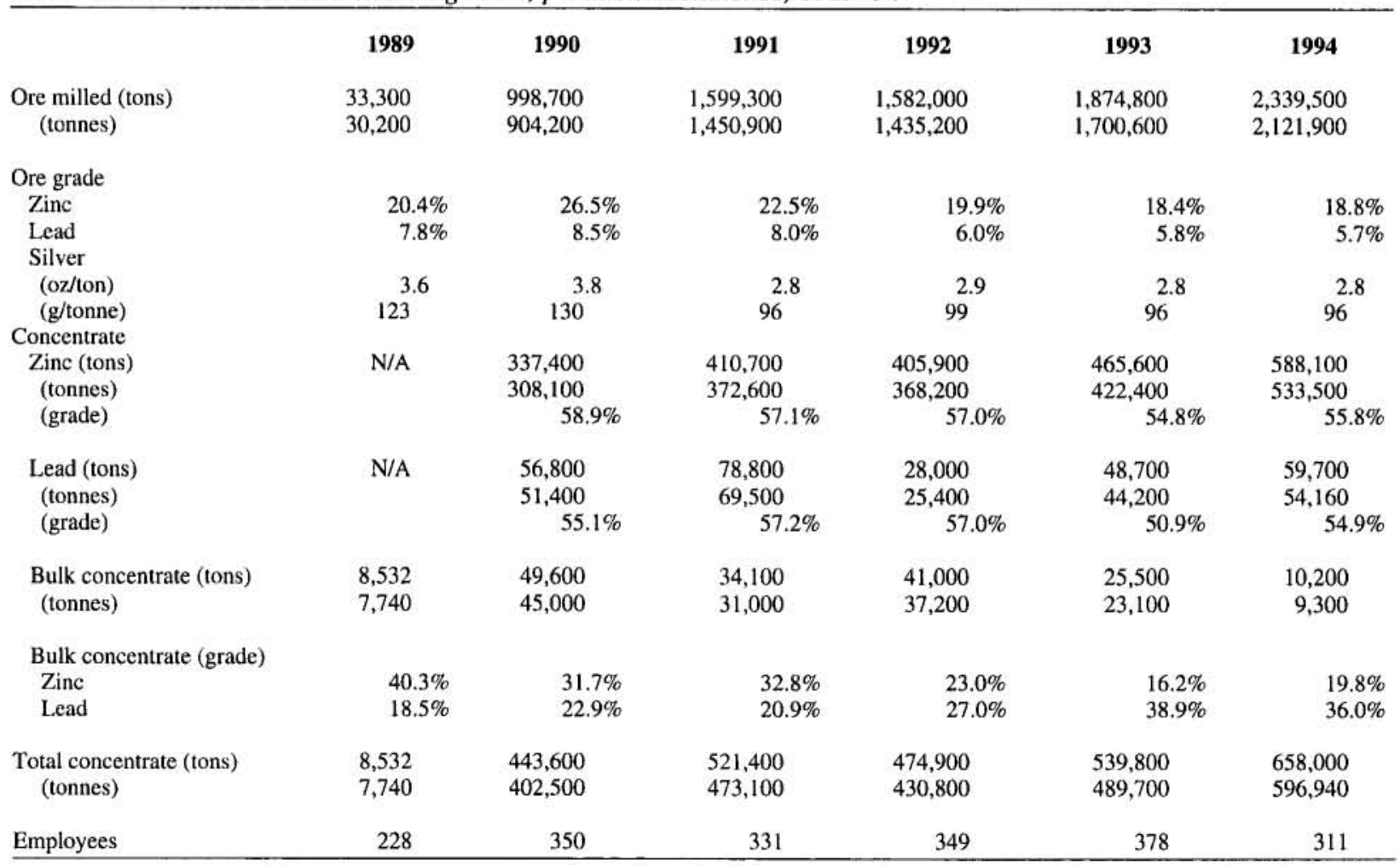

SoUrce: Jim Kulas, Cominco Alaska Inc. 
Paradise Valley Mining again operated a commercial placer mine in conjunction with a tourist-oriented recreational gold venture on Birch Creek east of Wild Lake. Lounsbury Mining mined a small paystreak in the Middle Fork of the Koyukuk River drainage.

\section{Industrial Minerals}

Four questionnaire respondents reported that $1,101,250$ tons (999,054 tonnes) of sand and gravel worth $\$ 5.2$ million were mined in the northern region, about double the 559,800 tons (507,850 tonnes) of sand and gravel worth $\$ 2.5$ million mined in 1993 (table 11). An additional 115,356 tons (104,650 tonnes) of stone worth $\$ 922,848$ was quarried for local construction uses in 1994; there was no recorded stone production from the northern region in 1993 (table 12). The U.S. Bureau of Land Management (BLM) reported that it used various sand and gravel pits along the Dalton Highway for repair of the Dalton Highway and TransAlaska Pipeline System (TAPS). Alyeska Pipeline Service Company also produced gravel and rock from 20 material sites along the TAPS corridor, which include many of the BLM gravel pits previously mentioned.

B.P. Exploration mined approximately 113,030 tons (102,540 tonnes) of gravel from two mine sites on the North Slope. Much of their effort focused on infrastructure development of the Niakuk and Point McIntyre petroleum fields northwest of the giant Prudhoe Bay petroleum deposits. (B.P. Exploration expected the Niakuk field to produce $25,000-35,000$ barrels of crude oil per day by mid 1995.) ARCO Alaska used approximately 48,860 tons ( 44,330 tonnes) of gravel for similar development purposes.

Stewarts Jewel Jade Company reported production of $\$ 20,000$ worth of cut and polished jade that originated from Dahl Creek north of the Arctic Circle. Jade bookends constitute the bulk of the final products marketed by the Anchorage-based company.

\section{COAL}

At the Kachiak Mine, Hobbs Industries, working for Arctic Slope Regional Corporation, mined and stockpiled approximately 2,000 tons ( 1,814 tonnes) of high-quality bituminous coals during underground development activities in the Deadfall Syncline area. The stockpiled coal is expected to be used for continuing village home-heating needs and for further bulk metallurgical testing for potential export market opportunities.

\section{WESTERN REGION}

\author{
Metals \\ Information received through both APMA and \\ DGGS questionnaires show that 32 placer mines in the
}

western region recovered an estimated 42,783 ounces (1,374 kilograms) of gold and byproduct silver worth $\$ 16.3$ million from the western region, down 14 percent from 1993 (table 9). The chief reason for the decline was reduced output from three large placer mines.

The leading gold producer was again the Alaska Gold Company, which operated two bucketline stacker dredges and one opencut mine in the Nome district. Both dredges are Yuba manufactured boats. Dredge 5 operated on either Third Beach or Monroeville Beach, an ancient shoreline of Norton Sound. With a displacement of 3,400 tons (3,084 tonnes), Dredge 5 has a daily digging capacity of 9,000 cubic yards $(6,880$ cubic meters). Dredge 6 worked a younger beach deposit west of the Nome Airport (fig. 19). With a displacement of 2,060 tons ( 1,868 tonnes), Dredge 6 has a daily digging capacity of 7,000 cubic yards $(5,350$ cubic meters). Dredge 6 may have seen its last productive season in the Nome district; the boat was mothballed in September, 1994. Dredge 5 operated for the entire 1994 season, and should operate through most of next season; future operations beyond 1995 are uncertain, however.

About 2 miles north of Nome Alaska Gold also operated an opencut placer mine that was developed by mechanical winter stripping and summer sluicing methods. Opencut mines using large earth-moving equipment are expected to take over most of the company's efforts in the Nome area. Alaska Gold produced 17,000 ounces ( 528 kilograms) of gold in 1994, 23 percent less than in 1993.

Dan Walsh mined high bench placers on Dexter Creek, while Bart Pettigrew worked auriferous pay on nearby Anvil Creek. Both creeks are among the largest producers of gold in the historic Nome mining district. Betty Krutzch mined placers in Specimen Gulch, an ancient bench level of Anvil Creek.

Steve's Repair (Steve Pomrenke) again mined an ancient shoreline of Norton sound near the Tripple and McDonald Creek drainages and washed 35,000 cubic yards ( 26,760 cubic meters) of auriferous pay. Pomrenke expects to have another successful season in 1995.

An estimated 125 hand miners and suction-dredge operators mined placer gold on public beach deposits along a 40-mile-long (60-kilometer-long) stretch of the Norton Sound coast. The majority of these beach miners, including Andy Hehnlin and Sons, operate on beaches from Hastings Creek to Cripple River, with a focus on ground immediately east and west of Nome (fig. 20).

East of the Seward Peninsula and into the lower Koyukuk and Yukon River basins, placer mining continued, but at reduced levels from previous years. Taiga Mining again leased the Hog River dredge from Alaska Gold Company and produced pay from virgin ground and dredge tailings. 
Sphinx Natural Resources and Malvy Technology Inc. again operated the largest placer mine in the RubyPoorman district on Monument Creek and sluiced 30,000 cubic yards $(22,940$ cubic meters) of auriferous pay. Late in the year the operation was sold to Moose Creek Apartments of Fairbanks. Green Mining and Exploration took out a cut on Birch Creek.

Also in the Ruby-Poorman area Flat Creek Mining mined pay on Timberline Creek, while Carl Bracale Jr. worked on Camp Creek, in the Kaiyuh Hills.

Rosander Mining Company mined with a crew of five on Colorado Creek, tributary to Innoko River. Manzie Magnuson worked his ground on Madison Creek, also a tributary of the Innoko River.

\section{Industrial Minerals}

From the western region four questionnaire respondents reported production of 426,000 tons ( 386,470 tonnes) of sand and gravel worth $\$ 2.24$ million and 65,000 tons (58,970 tonnes) of riprap worth $\$ 975,000$. Martinsen Gravel and Crane supplied sand and gravel to DOTPF road reconstruction efforts along the Nome-Council Road. Sound Quarry Inc. and Sitnasuak Corporation again operated the Cape Nome Quarry and shipped high quality riprap to several Bering Sea coastal erosion projects.

East of the Seward Peninsula, Galena Construction Company continued to extract sand and gravel from dewatered Yukon River gravel bars near Galena on an as-needed basis.
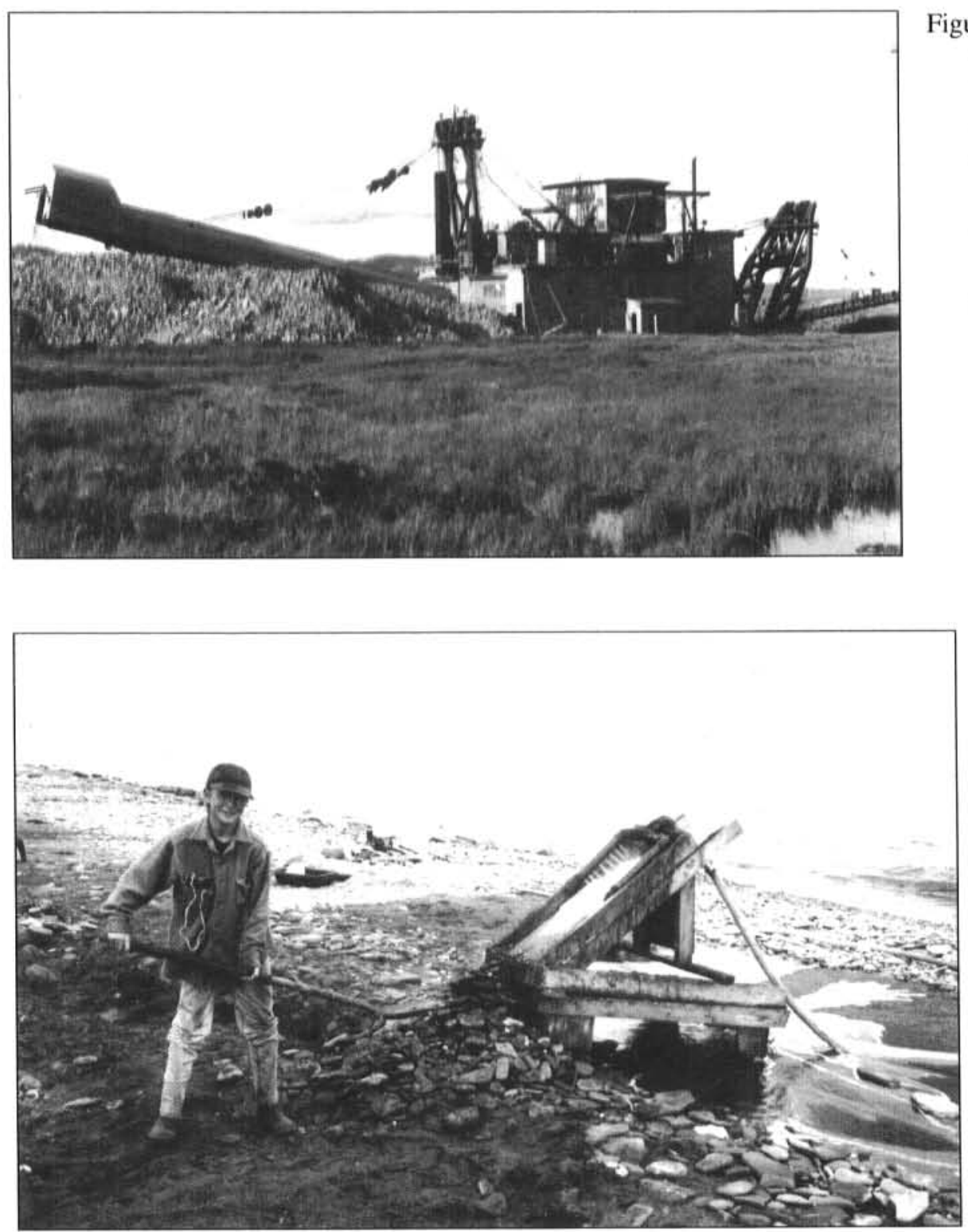

Figure 19. Alaska Gold Dredge Company's Dredge 6 at work on Submarine Bench, an ancient strandline west of the Nome airport. Dredge 6 was mothballed in September 1994 and is not expected to be restarted in the near future. Built from parts of USSR\&M Dredges I and 3, the reconstituted Dredge 6 operated from 1955 to 1962 and from 1975 to 1994. (Photo by Tom Bundtzen)
Figure 20. Robert Hehnlin at work mining placer gold on the Nome beachline. (Photo by Debbie Hehnlin) 


\section{EASTERN INTERIOR REGION}

\section{Metals}

During 1994, all metal production in the eastern interior region consisted of gold and byproduct silver from placer mines. Although many of the region's mines benefited from increasing gold prices, the slow but steady decline in the number of placer operations that began three years ago continued into 1994. Our records indicate that an estimated 103 placer mines produced 69,511 ounces (2,161 kilograms), a decrease of 10 percent in gold and 8 percent in the number of mines from 1993 (table 9). Reductions in placer mining activity have been particularly evident in the Circle, Bonnifield, Richardson, and Tofty mining areas; other Interior districts including the Fairbanks, Livengood, Fortymile, Rampart, and Eureka camps maintained mine activity at about the same levels as in previous years.

Fairbanks was again the largest gold producing district of the eastern interior region. Twelve placer mines produced 26,214 ounces ( 815 kilograms) of gold worth $\$ 10.1$ million in 1995 ; these levels were similar to levels of previous years. The Fairbanks district employed 116 workers.

Polar Mining Inc. operated two large placer gold mines in the Fairbanks district, and was Alaska's second largest producer of gold in 1994. The company processed 2.8 million cubic yards (2.14 million cubic meters) of auriferous gravel on Lower Goldstream Creek and 540,000 cubic yards ( 412,880 cubic meters) of auriferous gravel on Lower Fish Creek. Polar Mining provided 54 full-time-equivalent jobs to run both operations. Screened undersize and oversize aggregate from Polar's Lower Goldstream unit have become a popular upgraded product for the Fairbanks construction industry.

Cooks Mining again operated its long-time placer gold mine on Upper Fairbanks Creek. The company reported that the final mine cuts on the Upper Fairbanks ground will be finished in 1995; ground will be prepared for future operations on lower Fairbanks Creek starting in midsummer 1995. Alder Creek Mines sluiced a test cut adjacent to the old USSR\&M Dredge Number 2 tailings on the south limit of Fairbanks Creek, but concluded that gold values and stripping and handling material costs made the cost of a mine operation currently prohibitive at that location.

Alf Hopen finished his long-time mining operation on Little Eldorado Creek and won a certificate of recognition from the State of Alaska for outstanding reclamation work. He will begin to mine a paystreak on Cleary Creek in 1995. Victoria Creek Mine Inc. was again active on Victoria Creek. Don Stein and Goldstream Valley Exploration worked pay on Gilmore Creek.
In the Ester Dome area, The Mining Company (John E. McClain) finished its last mining season on Ester Creek, and won the State of Alaska's first annual Reclamation of the Year Award for outstanding reclamation of previously mined land. Roger Moore was mining in a nearby stream drainage. The Roman operation was again operating in the Fairbanks and Fish Creek drainages.

Three underground drift mines reported production work in 1994. Little Eldorado Group sustained a fullscale, underground drift mining operation on Little Eldorado Creek, and mined 5,100 cubic yards $(3,900 \mathrm{cu}-$ bic meters) during late winter and spring of 1994 and processed the high grade, auriferous pay during the summer of 1994. Little Eldorado Group plans to expand the operation to process 35,000 cubic yards ( 26,760 cubic meters) annually beginning in 1995 . Reserves are sufficient to maintain this level of operations for 6-8 years.

Sam Skidmore finally started underground production at his Vault Creek property, which he has been developing for several years now. Skidmore should be able to expand production levels somewhat in 1995. Reading Mine was again active in the nearby Treasure Creek drainage.

The Circle district was again one of the most active mining areas in the eastern interior region, but production levels continued to fall from previous years. Eleven operations reported 4,464 ounces (139 kilograms) of gold output worth $\$ 1.72$ million. About 48 people were employed in these mines.

Points North operation on Portage Creek was the biggest producer of gold in the Circle district in 1994. A crew of four sluiced approximately 100,000 cubic yards (76,460 cubic meters) during a 120-day season. A similar mine operation is planned for 1995 .

Paul and Company mined approximately $85,000 \mathrm{cu}-$ bic yards (64,990 cubic meters) of pay on Porcupine Creek, but reported a substantial operating loss for the year. The company will relocate to Fryingpan Creek in 1995. Paul and Company had previously operated one of the largest placer gold mines in the Circle district.

Other placer mines reporting production in the Circle district include: DOXAUCO and BHD Mining on the North Fork of Twelve Mile Creek; Wilde Enterprizes on Switch Creek; Dan Fair on Ptarmigan Creek; Underwood Ore Mining Company at 114 Mile Steese Highway; Ed Lapp on Eagle Creek; Steve Olson also on Eagle Creek; Greenhorn Mining on Ketchum Creek; and Sam Koppenberg on Faith Creek.

Alaska Placer Development worked its Livengood Bench deposit for the eleventh consecutive year, and was the fifth largest gold producer in Alaska in 1994 (figs. 21 and 22). A crew of 8-10 processed about 156,000 cubic yards (119,280 cubic meters) of auriferous pay using opencut-hydraulic mine technology. The ground has 
been leased from Coeur d'Alene Mines for years, but negotiations for outright purchase by Alaska Placer Development were in progress at the end of the year.

Five operations reported gold production in the Eureka-Manley and Rampart districts. Kelly Mining continued to mine pay on Eureka Creek near Manley but struggled with worn-out equipment. Ed Salter also mined a paystreak on Eureka Creek. Thanksgiving Mining worked on Thanksgiving Creek for 100 days but managed to sluice for only 32 hours at 35 yards per hour. Delima Placers mined 40,000 cubic yards $(30,580$ cubic meters) on American Creek for 90 days with a crew of three. Cassiterite Placers resumed operations at Tofty on ground previously leased by GHD Resources Inc.

The Forty Mile district was again dominated by smaller mechanized mines and suction dredge operations. APMA permits, Alaska Mining Licenses, and DGGS Questionnaires indicate that about 20 small operations were active. Roger Tallini worked pay with a large suction dredge on the South Fork of the Fortymile River; but his 1994 season was handicapped by lowwater conditions. The long-time partnership of Mike Buzby and Alice Bayless leased ground from the Alaska Gold Company near Chicken. They worked the Mabel, Margaurite, Fisher, and Meyers bench deposits and conducted reclamation activities as well. Fortyfive Pup Mining continued their long-time operation on Fortyfive
Pup, but encountered below-average pay and numerous equipment breakdowns. Larry Taylor worked ground on the main Fortymile River, but encountered "mile-high" paperwork problems with mine operations. Roger Tallini worked his suction dredge on the South Fork of Fortymile River (fig. 23). Cy Bras worked a placer deposit on Canyon Creek near Boundary (fig. 24).

Earl Voytilla worked his claims near the head of Tenderfoot Creek in the Richardson district. John Rubel took out a small cut in the saddle between Democrat and Junction Creeks, about 10 miles (15 kilometers) northwest of the Voytilla operation.

The Bonnifield district maintained production levels of last year, but mine operators couldn't regain production levels of several years ago when large-scale placer mines worked paystreaks on Grubstake and Moose Creeks. D'Log Industries (Ferrel Woods) mined ground on Bonnifield Creek and was encouraged with its 1994 test run of the pay zone, for which recovered values averaged about $\$ 4.00$ per cubic yard $(\$ 3.06$ per cubic meter), while mine costs ran about $\$ 1.75$ per cubic yard (\$1.34 per cubic meter). Gypsy Luck Mine and Tachick Mining Company mined pay in the Healy area, but both companies encountered equipment breakdowns and water control problems during the season.

Two mining companies reported gold production in the upper Delta River drainage. Glacier Six Enterprizes

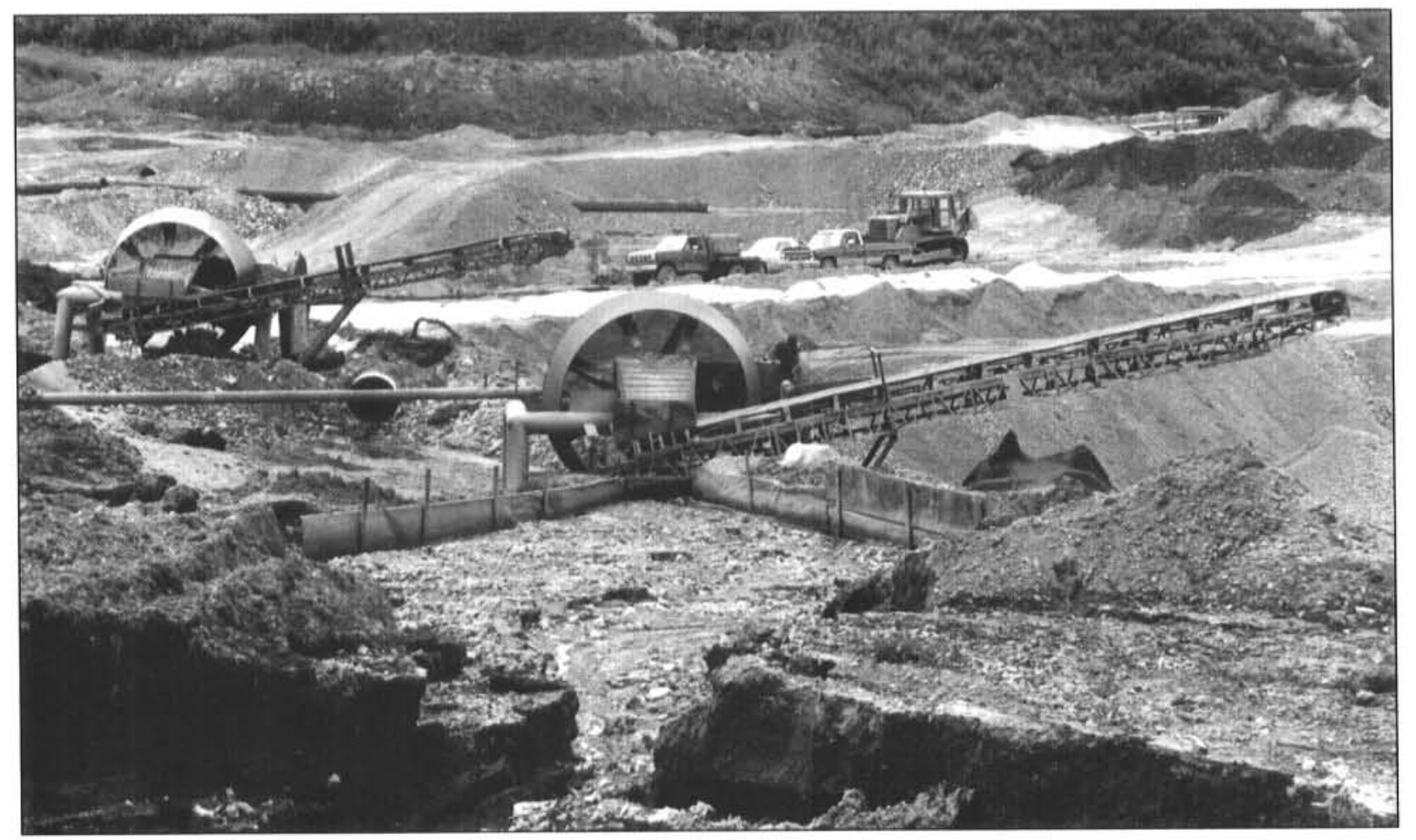

Figure 21. "Fish wheels" designed to remove slide-rock from the slurry drain at Alaska Placer Development's Livengood operation. (Photo by Dick Swainbank) 
continued large-scale production testing at its Broxson Gulch property west of Summit Lake. Much of the 1994 season was spent preparing for an expanded effort in 1995. Victory Mines worked ground on nearby Rainy Creek.

Wayne Gibson mined pay with a dragline operation on Golden Creek in the Tozi-Moran district west of Tanana. Mines in this placer district are usually credited with small amounts of tin byproduct during gold recovery.

\section{Industrial Minerals}

An estimated 5.53 million tons (5.02 million tonnes) of sand and gravel worth $\$ 14.4$ million was quarried from pits throughout the eastern interior region. This level was about the same as that established in previous years (table 11). Much of this total was associated with Federal and State Department of Transportation and Public Facilities (DOTPF) highway reconstruction work, which used embankment and surfacing aggregate on the Alaska Highway and Taylor Highway projects. DOTPF reported that its projects included 5,241,178 tons $(4,754,795$ tonnes) of sand and gravel and fill dirt or nearly 95 percent of the total reported from the eastern interior region during 1994. One of the larger sand and gravel projects near Fairbanks, the Goldstream Road reconstruction project, used mine tailings from Goldstream Valley near Fox and used sized materials produced as a byproduct of Polar Mining's placer gold mine in Lower Goldstream Valley. The Goldstream Road project also reprocessed about 45,000 tons $(40,820$ tonnes) of blacktop stockpiled from previous road reconstruction efforts in the Fairbanks area.

Three companies reported that they used 185,360 tons ( 168,160 tonnes) of stone worth an estimated $\$ 1.4$ million in the eastern interior, mainly for erosion control. DOTPF contracted work aimed at mitigating serious erosion control problems along the Richardson Highway near Delta, where the Tanana River has threatened the roadbed. Yutan Construction Company mined basalt for D-1 (asphalt applications) and riprap projects in the Fairbanks area.

\section{Coal and Peat}

Usibelli Coal Mine Inc. produced steam coal for both interior electric power plants and for export to the Korean Electric Power Company (KEPCO) in Honam, South Korea. About half the 1.49 million tons ( 1.35 million tonnes) coal was used

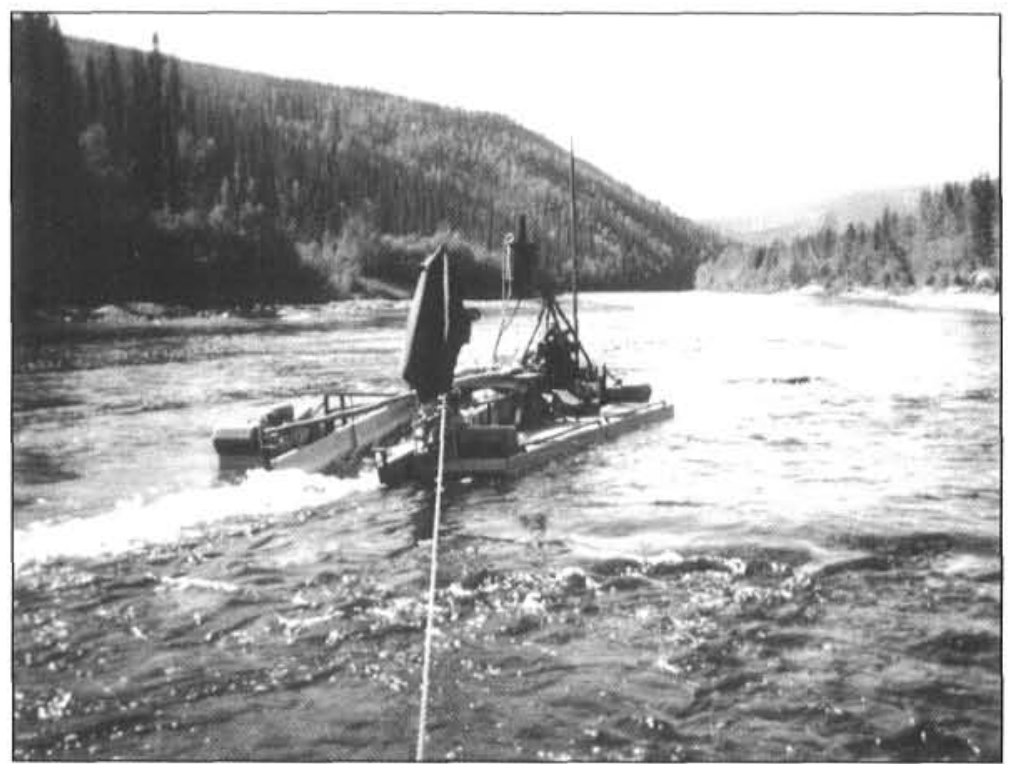

Figure 23. Roger Tallini operated a suction dredge on the South Fork of the Fortymile River during the 1994 season. In the last several years numerous suction dredges have been employed in the Fortymile district. (Photo by Roger Tallini) 
in Alaska, and the remainder was shipped by Alaska Railroad Corporation unit trains to the Port of Seward for export. Contract negotiations with KEPCO were concluded on December 28, 1994, when an export agreement for 1995 was signed by Usibelli, KEPCO, and Suneel Shipping Company - for the first time in years, without a significant price reduction. International prices for steam coal rose significantly in late 1994 and in the spring of 1995, which is welcomed by Alaska's coal export industry.

Peat and fill dirt, mainly for landscaping applications, was reported by one operator, Great Northwest. The company mined approximately 20,000 cubic yards $(15,290$ cubic meters) of peat and fill dirt from their College Road pits, which are leased from the University of Alaska in Fairbanks.

\section{SOUTHCENTRAL REGION}

\section{Metals}

Gold production returns from ten mining companies and from APMA permit records show that gold production in the southcentral region increased from 42,268 ounces $(1,313$ kilograms $)$ of gold in 1993 to
49,723 ounces ( 1,546 kilograms) of gold in 1994, an increase of 18 percent. Employment levels, however, remained the same for both 1993 and 1994 (table 9).

Cambior Alaska again operated Alaska's largest gold mine at its Valdez Creek placer property, about 55 miles (89 kilometers) east of Cantwell. During the year Cambior provided 151 full-time jobs, processed 1.26 million cubic yards ( 0.96 million cubic meters) of auriferous pay, and produced 47,622 ounces ( 1,480 kilograms) of refined gold $(55,894$ ounces or 1,738 kilograms of raw gold). This level of production makes the Valdez Creek operation one of the largest placer gold mines in the world. Cumulative production through eleven years of operation (1984-1994) has been 422,743 ounces $(13,147$ kilograms) of refined gold worth about $\$ 156$ million at the time of bullion sales (table 14). On July 15, 1994, Cambior announced that the Valdez Creek property was entering its final productive stages, and was scheduled for permanent closure on September 30, 1995. Available reserves have apparently been exhausted and exploration has been discontinued. Cambior will begin a phased layoff of employees beginning March 31, 1995, which will continue until the mine closes. During 1994, the company began an aggressive

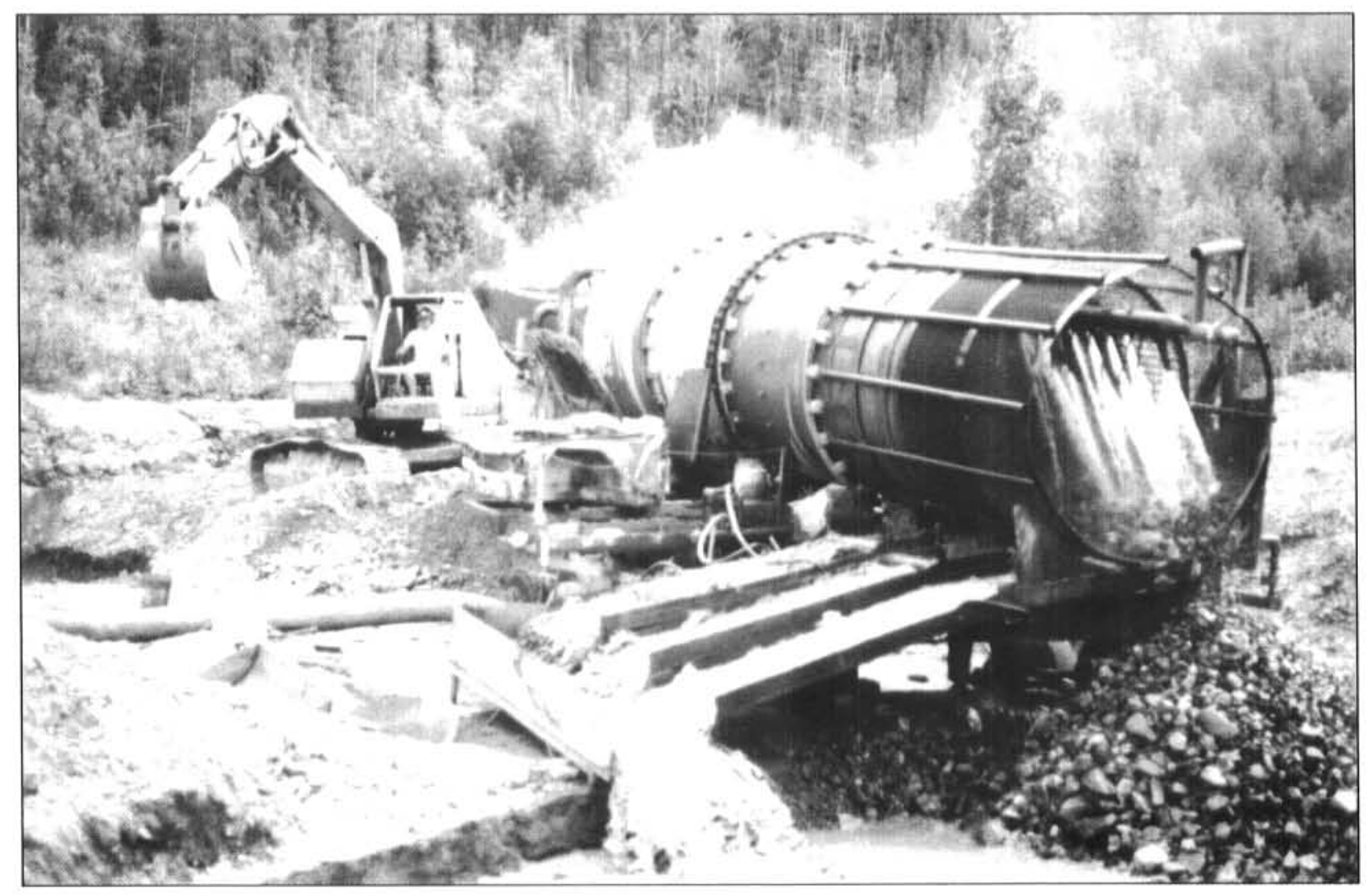

Figure 24. Cy Bras feeds a trommel-screen washing plant on Canyon Creek of the Fortymile district near Boundary in eastcentral Alaska. The trommel is the same design used in floating, bucketline stacker dredges that are operated throughout Alaska. (Photo by Rick VanHatten) 
mine closure program emphasizing reclamation and related activities. The Valdez Creek Mine has been one of the largest single tax-revenue sources for the Matanuska-Susitna Borough.

Small-scale placer gold mines produced gold throughout southcentral Alaska. Girdwood Mining Company was the second largest gold mine in the southcentral region. Girdwood, with five employees, sluiced 35,000 cubic yards (26,760 cubic meters) of auriferous pay at their Girdwood Alaska operation and expect to operate at a similar level in 1995.

Arnold Mason conducted production tests for about 150 days in 1994 on his mine property in the Nelchina district, and expects to reach full production in 1995. Long-time placer miner Willie Mrak operated a small plant on his Ellie Number One claims on Willow Creek, using a crew of two that sluiced for about two hours a day during a 100-day mining season.

Three mining companies reported production from the Cache Creek-Yentna district. Empire Exploration Inc. and partner Aces High Inc. completed a 450-cubic-yard (344-cubic-meter) production test on a residual placer overlying the Blue Ribbon goldquartz mesothermal vein deposit in the YentnaCache Creek district (fig. 25). The partnership plans to upgrade the production in 1995. Delays during 1994 were caused largely by the unfortunate death of Don Gates, who designed the washing plant for the two companies.

$\mathrm{H}$ and $\mathrm{H}$ Exploration and Mining worked a small paystreak on Boulder Creek in the Collinsville area and plans to do more exploration work in 1995 before further mining activity is resumed.

Lake Creek Placers Inc. continued a test cut on Lake Creek near Petersville in the Yentna-Cache Creek district. Lake Creek built a 26-mile-long (42-kilometerlong) winter haul road in the spring of 1994 and constructed an effluent pond in late summer. A testsized washing plant began processing auriferous gravels in September before freeze-up. The company plans to install a 200-cubic-yard-per-day (153-cubic-meter-perday) wash plant for use in 1995 . Gold resources in the Lake Creek property are contained within a 500,000 cubic yard $(382,300$ cubic meter) placer deposit.

Three placer mines were active on the Kenai Peninsula. AG Building Supply worked a small placer paystreak with a suction dredge near Hope, and will continue the project in 1995. Gene Granath again worked his Falls Creek paystreak near Moose Pass and may expand his suction dredge operation in 1995. John Trautner continued to produce placer gold from his Canyon Creek deposits also near Moose Pass and worked on federal patent applications for the property.
Table 14. Production of refined ounces of gold from Valdez Creek Mine 1984-94

\begin{tabular}{lcr} 
Year & $\begin{array}{c}\text { Production } \\
\text { (ounces refined) }\end{array}$ & $\begin{array}{c}\text { Value } \\
\text { (at time of sale) }\end{array}$ \\
1984 & 19,627 & $\$ 7,065,720$ \\
1985 & 29,833 & $9,606,226$ \\
1986 & 24,996 & $9,498,480$ \\
1987 & 21,068 & $9,585,940$ \\
1988 & 44,494 & $18,909,950$ \\
1989 & 62,403 & $22,980,500$ \\
1990 & 8,031 & $3,091,917$ \\
1991 & 43,057 & $15,586,634$ \\
1992 & 86,052 & $28,999,524$ \\
1993 & 35,560 & $12,766,040$ \\
1994 & 47,622 & $18,334,470$ \\
Total refined gold & $\mathbf{4 2 2 , 7 4 3}$ & $\mathbf{\$ 1 5 6 , 4 2 5 , 4 1 9}$ \\
(Total raw gold) & $\mathbf{4 9 8 , 5 0 0}$ & \\
\hline
\end{tabular}

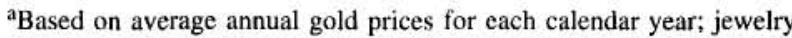
premiums from sale of gold nuggets or upfront sales agreements not taken into account.

\section{Industrial Minerals}

Nine companies and government respondents reported production of 5.56 million tons (5.04 million tonnes) of sand and gravel worth an estimated $\$ 15.6$ million from the southcentral region (table 11). Major road reconstruction projects including the Sterling highway on the Kenai Peninsula, the Glenn Highway north of Anchorage, and the Richardson Highway north of Valdez accounted for 3.65 million tons (3.31 million tonnes) or nearly 66 percent of the regional volume totals. The Alaska Railroad Corporation shipped $2,060,429$ tons $(1,869,220$ tonnes) of sand and gravel aboard unit trains from pits near Palmer to the Anchorage area for construction use throughout the municipality. This total is about 600,000 tons (635,040 tonnes) short of 1993 levels, but up from the railroad haulage estimates given during the 1989-1992 calendar years.

Chugach Alaska Corporation sold about 180,000 tons (163,300 tonnes) of sand and gravel from various locations in the southcentral region all subcontracted to third party vendors; they expect similar activity levels in 1995. Hermon Brothers Construction Company quarried pit-run gravel and crushed aggregate from pits in the Matanuska-Susitna valley for local markets. Alaska Gravel Sales operated pits on the corner of Platt Road and Lake Otis Blvd. in Anchorage. Melvin Tippston also worked his gravel operations in the Anchorage area.

Two companies quarried gravel in the Kenai-Soldotna area. Fairway Gravel provided pit-run gravel in the Funny River area. Jackson Construction Company 


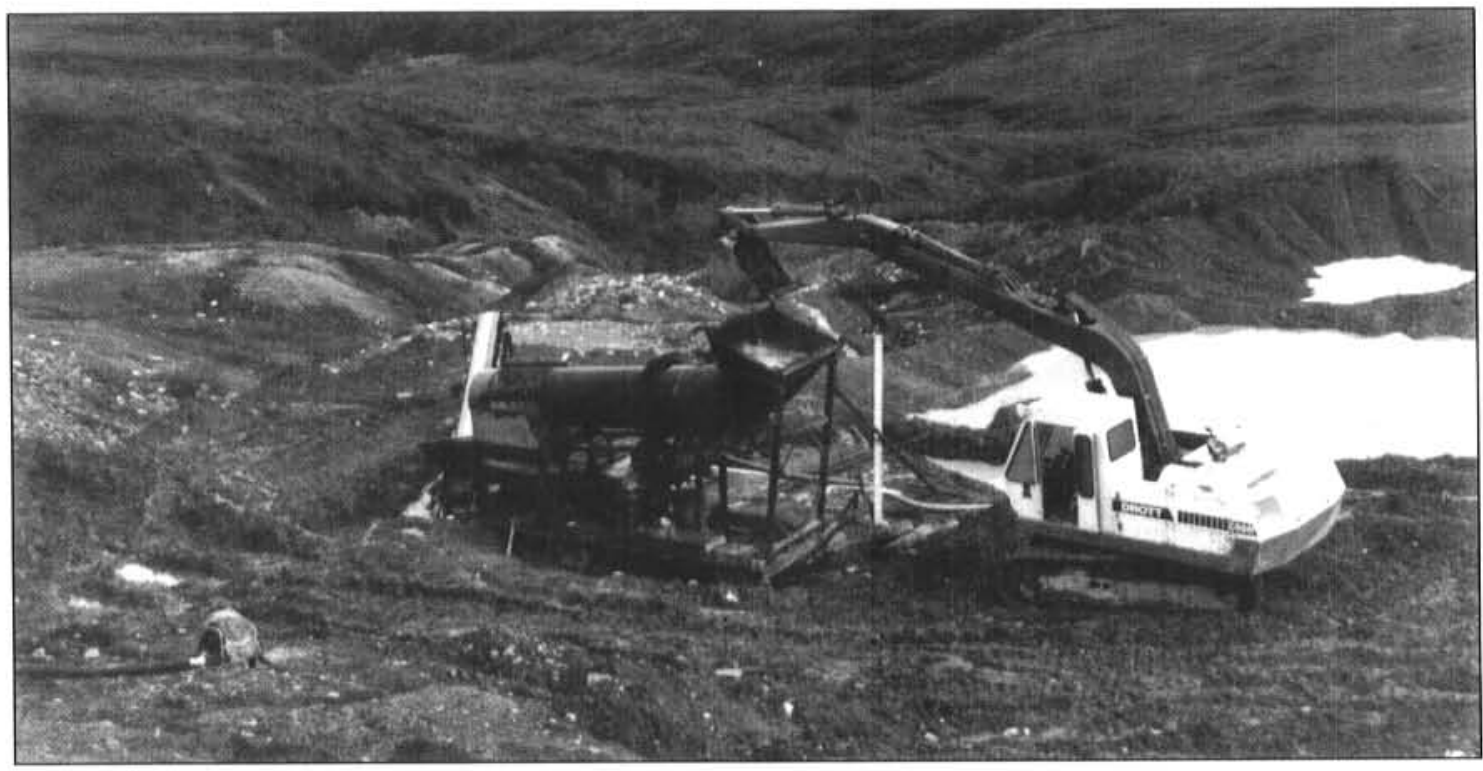

Figure 25. Empire Exploration Inc. feeds a trommel-equipped washing plant with a backhoe at the Blue Ribbon Mine in the Cache Creek-Yentna district west of Talkeetna. (Photo by Dennis Garrett)

dredged and baled gravel and sand from private property near Soldotna.

Rex Brown continued sand and gravel production in the Valdez area.

\section{Peat}

Three companies and one government agency produced about 67,900 cubic yards $(51,920$ cubic meters) of peat and fill dirt for landscaping applications in the southcentral region. A and A Services and The Dirt Company mined peat and fill dirt from several locations near Anchorage. Landscape Supply Company sold 9,000 cubic yards $(6,880$ cubic meters) of peat to landscaping companies in the Palmer-Wasilla area. DOTPF projects used about 35,000 cubic yards (26,760 cubic meters) of peat for landscaping newly rebuilt portions of the Glenn and Sterling highways.

\section{SOUTHWESTERN REGION}

\section{Metals}

Seventeen companies produced 9,650 ounces (300 kilograms) of gold worth $\$ 3.7$ million in the southwestern region, about the same amount as in 1993 (table 9). Four operations produced gold in the AniakTuluksak district. Nyac Mining Company, in partnership with Calista Corporation, operated the largest placer mine in southwest Alaska on Bear Creek south of Aniak, but at reduced levels of production from previous years.

Further north in the Donlin Creek area, Lyman Resources of Alaska leased ground from Calista Corporation and mined 7,000 cubic yards $(5,350$ cubic meters) of pay on Queen Gulch; they finally had a successful year from reliable, profitable ground. The old timers apparently missed much of the pay in the Gulch because of the wet and thawed conditions now being encountered by Lyman. The company anticipates an even better year in 1995. Other mining companies active in the Aniak-Tuluksak district include Millie Creek Mine near Red Devil and Mark Matter on Marvel Creek.

In the Marshall district Dave Penz operated Kako Creek Mine for the ninth consecutive year, but experienced problems with excessive rain and mechanical breakdowns. Ernie Chase took out a cut at Stuyahok west of Holy Cross, and will upgrade his operation in 1995.

In the Iditarod district, Prince Creek Mining took out cuts on their Valley Claim, managing to sluice only 103 hours during the season. Silt and clay in the payzone has caused excessive wear on the pumps and clogged the riffles during sluicing. Misco-Walsh Mining Company mined the residual placers atop the Golden Horn Mine near Flat using hydraulic methods, and recovered scheelite, auriferous arsenopyrite, and stibnite in addition to the gold. Ann Williams took out a cut on Granite Creek across from Otter Creek and about 2 miles (3.2 kilometers) from the Golden Horn Mine. Wilbur Williams, Ann Williams' husband and mining partner, who had mined in the district for nearly 45 years, was killed in an accident in Flat on July 1, 1994.

Others active in the district include Flat Creek Placers on Flat Creek and Richard Wilmarth on Chicken Creek. L.E. Wyrick has mined gold since 1985 on Granite Creek, a tributary to the George River. 
Four mining companies reported production from the Innoko district west of McGrath. Little Creek Mine processed more than 50,000 cubic yards $(38,230$ cubic meters) of auriferous pay on Little Creek, a tributary to the Innoko River, and the company predicts "more of the same" for 1995. Anderson and Son Mining worked a paystreak on Yankee Creek for 120 days with a crew of three; no major problems were reported. The company plans to mine about 3 acres (1.2 hectares) in 1995.

Doug Clark and partners completed their first full season of placer mining on Ganes Creek, a major tributary to the Innoko River west of McGrath. Clark purchased the property from long-time mine operator Magnuson Mining Company in 1993. Work in 1994 concentrated on evaluating the auriferous pups along the east limit of Ganes Creek. Several large, multi-ounce gold nuggets were recovered from the pups. The nuggets undoubtedly were derived from the mineralized Ganes-Yankee Creek dike swarm, and not from ancient benches of Ganes Creek proper (Bundtzen, 1981; Miller and Bundtzen, 1994).

Robbie Roberts was again active on Ophir Creek, site of the original gold discoveries in the Innoko district.

\section{Industrial Minerals}

Two companies mined 178,600 tons (162,025 tonnes) of sand and gravel worth $\$ 444,390$ in the southwestern region (table 11). Knik Construction Company mined gravel from a pit near the village of Platinum for sand and gravel use in erosion control and other applications in Bethel. Calista Corporation mined or sold 163,000 tons (147,870 tonnes) of sand and gravel from various sites throughout its region for local construction needs.

\section{ALASKA PENINSULA REGION}

\section{Industrial Minerals}

The City of Kodiak used sand and gravel from its Pillar Mountain pit and sand from Pillar Creek for local municipal needs. Koniag Inc. mined approximately 475,000 tons (430,920 tonnes) of rock used to construct a logging road on Afognak Island, and approximately 283,500 tons $(257,190$ tonnes $)$ of sand and gravel for State DOTPF airport improvements.

\section{SOUTHEASTERN REGION}

\section{Metals}

Two small gold mines reported gold production in the southeastern region. Snow Lion Mining Company continued to dig pits and test gold content in the 85foot-thick (26-meter-thick) paystreak of the Porcupine Creek drainage. This company uses a hydraulic winch that is the heart of a stackline excavator system, a technology that is considered essential in the boulder-ridden paystreak (figs. 26 and 27).

Big Nugget Mine processed another 10,000 cubic yards (7,646 cubic meters) of auriferous pay also on Porcupine Creek, near Haines. Big Nugget Mine encountered no serious problems, but they are worried about future reserves.

Although the Greens Creek polymetallic mine on Admiralty Island closed in 1993 (figs. 28 and 29), the owners and federal government have made an agreement that paves the way for reopening the mine. Kennecott-Greens Creek Mining Company, a past producer of silver, zinc, gold, and lead, will pay $\$ 1$ million and up to 3 percent royalty to the USFS when the mine resumes production, In return USFS will open for development an additional 7,500 acres (3,036 hectares) of highly mineralized ground near the existing mine (Hoffman and Albanese, 1995; Apel, 1995).

\section{Industrial Minerals}

The southeastern region continued to lead the state in stone production. Southeastern stone together with its sand and gravel provided 78 percent of all the stone used throughout the state in 1994. Stone production amounted to $3,001,664$ tons $(2,723,110$ tonnes), worth $\$ 21$ million; sand and gravel production amounted to 603,420 tons $(547,420$ tonnes, worth $\$ 2.78$ million (tables 11 and 12). The continuing high levels of stone production is the result of road construction associated with the forest products industry throughout the panhandle.

Hildre Sand and Gravel mined 105,700 tons ( 95,890 tonnes) of sand and gravel for local building needs from pits north of Juneau. Ritchie Transportation Company Inc. dredged sand and gravel from the Stikine River for building needs in and near Wrangell; Ritchie reported that 1994 was a good year. Highdrive Drilling and Blasting mined about 500,000 cubic yards (382,300 cubic meters) of both sand and gravel and stone for construction work on Prince of Wales Island. Ron Thomas worked sand and gravel pits near Hyder for local markets. Pate Construction quarried gravel at Yakutat for local commercial uses.

One small municipality reported industrial mineral mining activities. The City of Thorne Bay mined about 6,000 cubic yards ( 4,588 cubic meters) of shot rock for use in Thorne Bay; the rock pit is scheduled to be developed as commercial property after the mining is completed.

The Cordova and Petersburg offices of the U.S. Forest Service leased quarries to small companies that mined small tonnages of blend sand, rock, and sand and gravel to private construction firms during the year. 
Sealaska Corporation quarried 2.40 million tons (2.18 million tonnes) of shot rock for various market uses throughout its region. Major problems listed by the corporation include permitting delays mainly related to water-use issues and to U.S. Forest Service Plan of Operation Approvals.

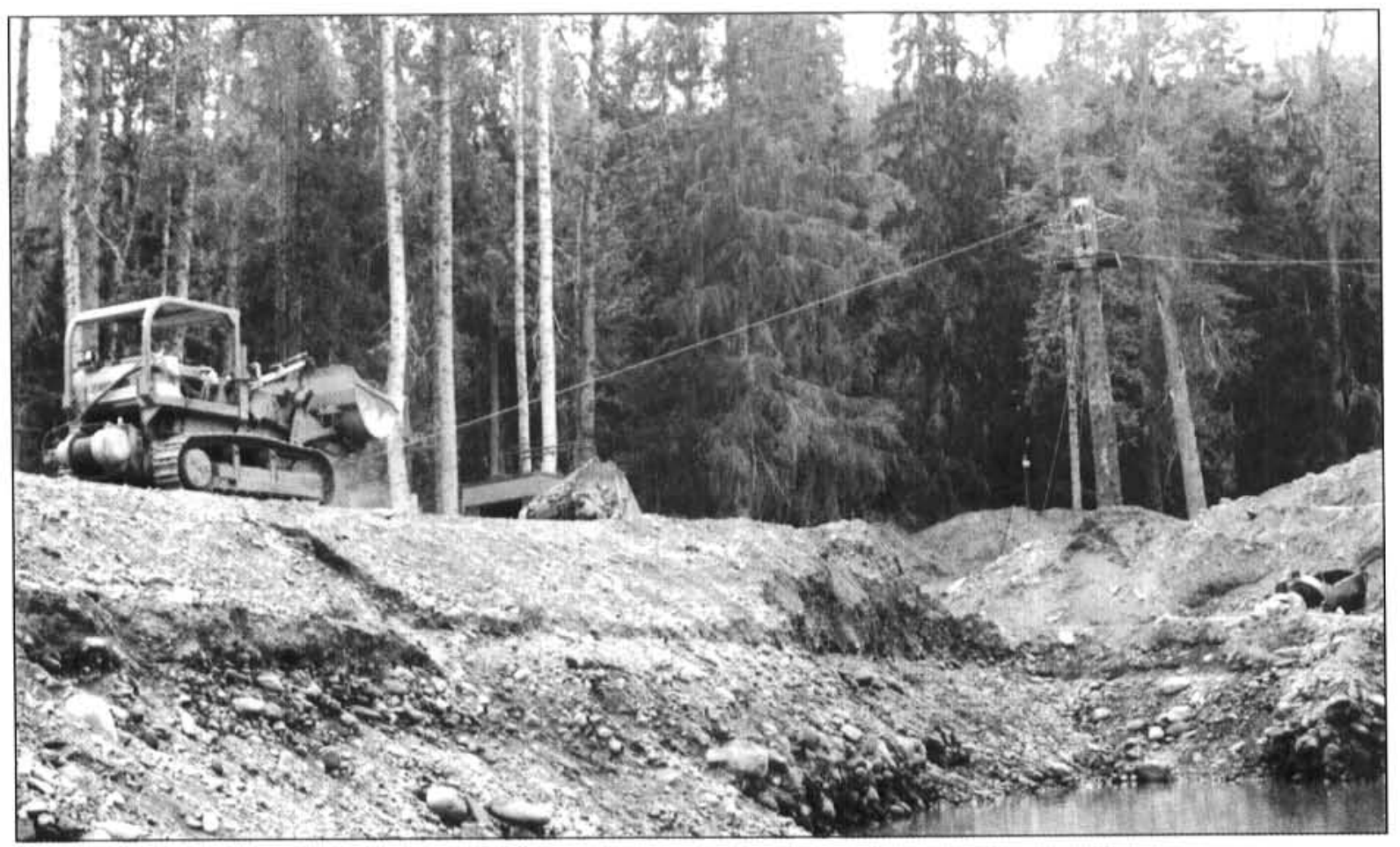

Figure 26. Snow Lion Mining Company hydraulic winch system at work in the Porcupine district north of Haines in southeast Alaska. Power is supplied to the stackline by a 3-cubic-yard (2.3-cubic-meter) track loader with a 44,999-pound $(20,412$ kilogram) capacity hydraulicpull winch. (Photo by Snow Lion Mining Company)

Figure 27. In the boulder-ridden Porcupine paystreak Snow Lion excavates and digs with $a$ 2-cubic-yard (1.5-cubic-meter) dragline bucket rigged to a stackline system. (Photo by Snow Lion Mining Company)

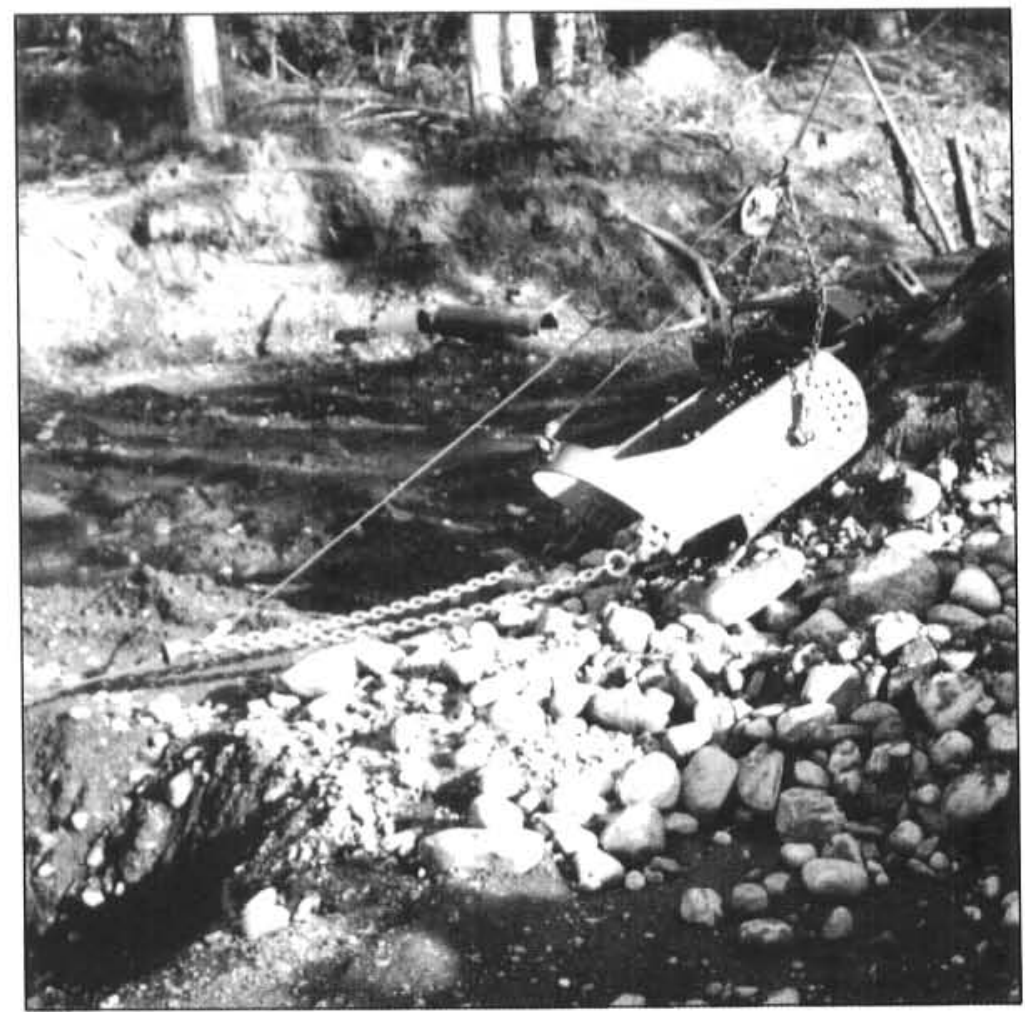




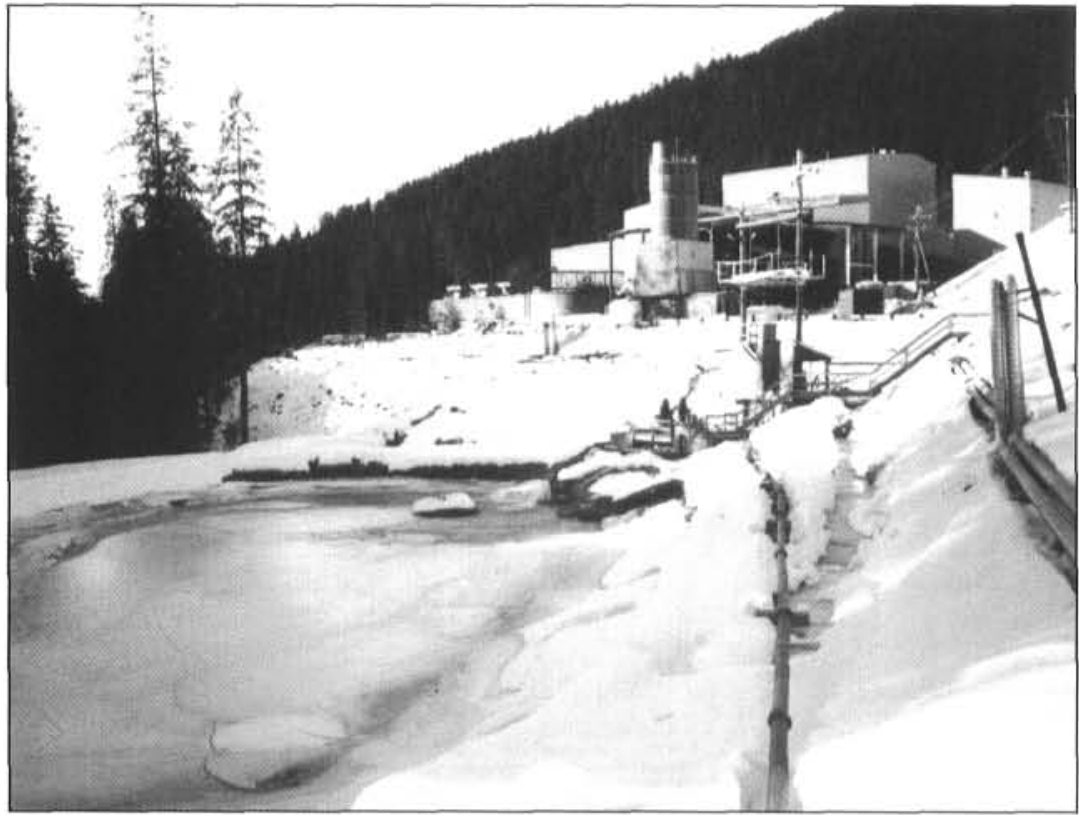

Figure 28. Winter view of the Greens Creek polymetallic mine and mill facility on Admiralty Island, west of Juneau. The mine shut down in 1993, but new exploratory results and improving metal prices may lead to its reopening by 1997. (Photo by $\mathrm{Al}$ Clough)

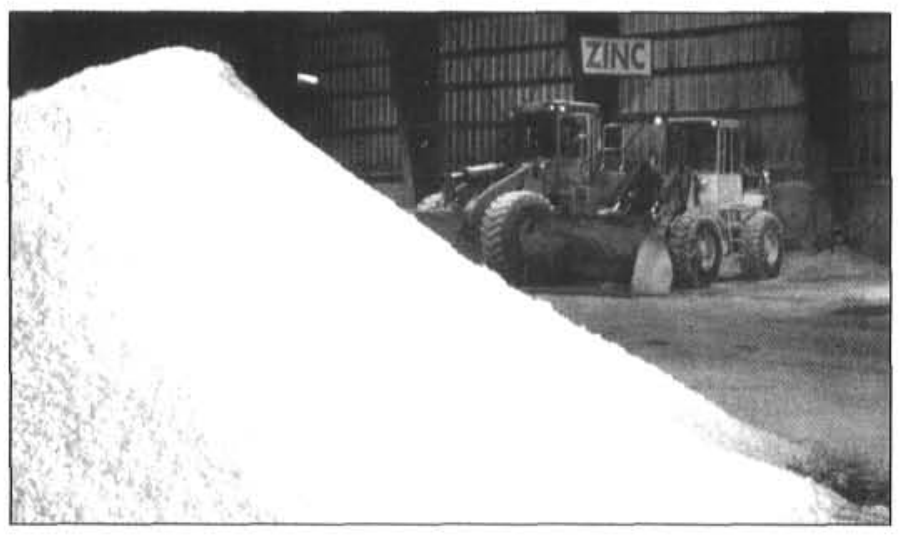

Figure 29. Front-end loader stockpiles processed zinc concentrate at the Greens Creek Mine in 1993. (Photo by Al Clough)

\section{DRILLING}

The total drilling reported in Alaska in 1994 was 467,878 feet (141,781 meters) compared with 277,531 feet $(84,591$ meters) in 1993 (fig. 30). Tables 15, 16, and 17 and contain the information reported for significant drilling programs, the summary drill footage reported over the last eight years, and the regional distribution of the 1994 drilling.

\section{PLACER DRILLING}

Placer drilling was reported in the northern region at Nolan Creek in the Wiseman area, and in the Fairbanks area.

\section{COAL DRILLING}

Arctic Slope Consulting Group had a modest coal drilling program associated with the exploration and development at the Kuchiak mine site in the northwest arctic coalfields, and Usibelli Coal Mine Inc. did a little drilling on Two Bull Ridge near Healy in interior Alaska.

\section{HARD ROCK DRILLING}

Almost 80 percent of the 438,000 feet (133,502 meters) of hardrock drilling in 1994 was core drilling, and about 68 percent of that 347,000 feet $(105,765$ meters $)$ of core-drilling was underground drilling at the A-J and Greens Creek Mines.

Reverse-circulation drilling has, except for 1993, lagged behind core drilling, and in 1994 the amount of core drilling far exceeded reported reverse-circulation drilling.

Substantial hard-rock drilling programs in 1994 


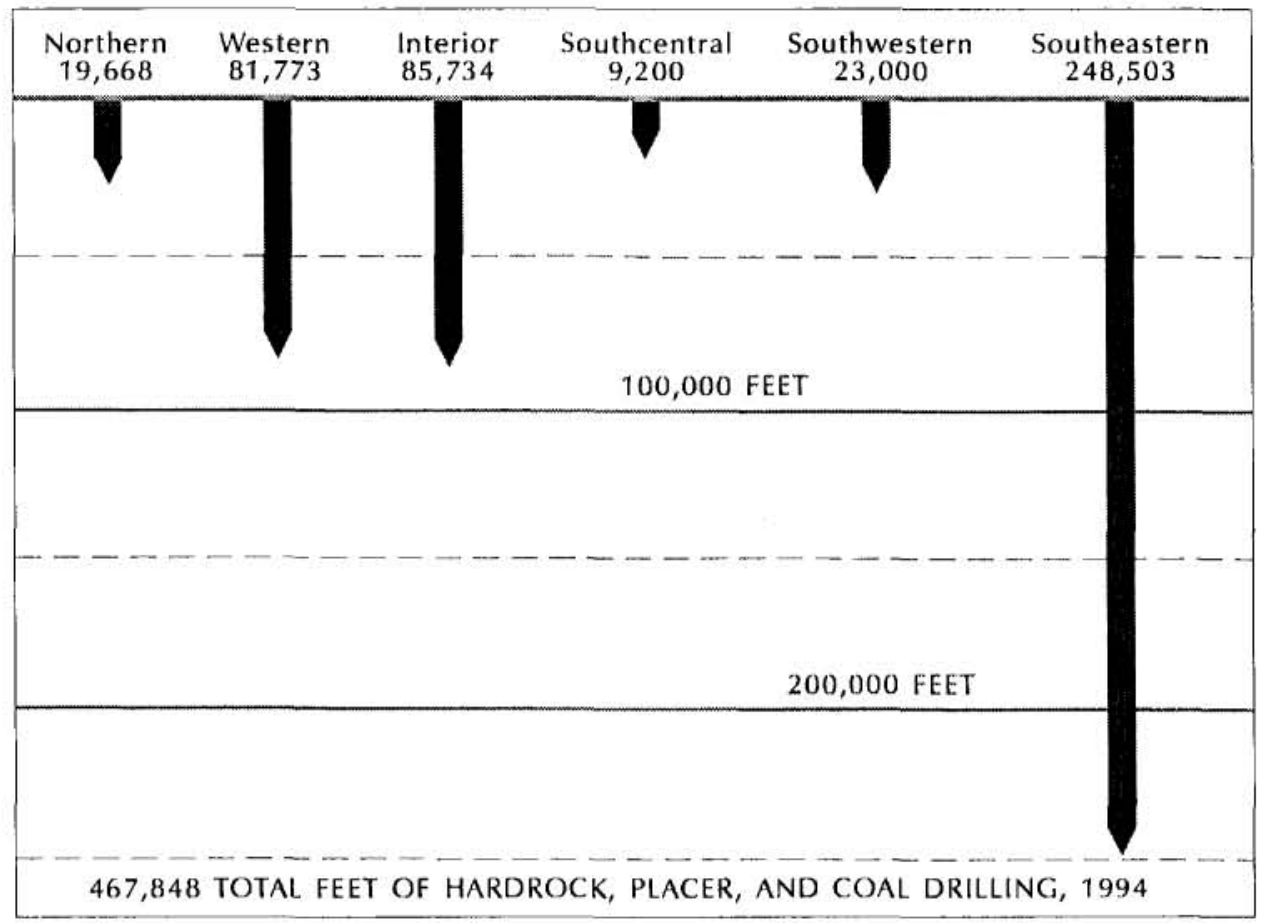

Figure 30. Hard rock, placer, and coal drilling totals for 1994.

were reported at Vinasale Mountain and Nixon Fork near McGrath; at Illinois Creek near Nulato; near Nome and Candle on the Seward Peninsula; at Fort Knox, True North, Ester Dome, and Stoneboy Creek near Fairbanks; at the Golden Zone and Zackley properties in the Alaska Range; at Goodnews Bay in southwest Alaska; at Haines, Prince of Wales Island; and near Juneau in southeast Alaska. This list shows that years of grassroots exploration has resulted in numerous targets throughout the state with sufficient potential to be worth a drill program.

Table 15. Companies reporting significant drilling programs in Alaska in 1994

Addwest Minerals Inc.

Apollo Resources Inc.

Arctic Slope Consulting Group

ASA Inc.

Cominco Alaska Exploration Inc.

Consolidated Nevada Goldfields Co. Silverado Mines Ltd.

Echo Bay Alaska Inc.

Fairbanks Gold Mining Inc.

Kennecott Exploration Inc.
Kennecott-Greens Creek La Teko Resources Ltd. Noranda Exploration Inc. Polar Mining Inc.

Sealaska Corp.

Starcore Resources Ltd. USMX Inc . WGM Inc.

Table 16. Drilling footage reported in Alaska, 1986-94 ${ }^{a}$

\begin{tabular}{|c|c|c|c|c|c|c|c|c|c|}
\hline & 1986 & 1987 & 1988 & 1989 & 1990 & 1991 & 1992 & 1993 & 1994 \\
\hline Placer exploration & 32,400 & 50,250 & 152,000 & 97,250 & 78,930 & 51,247 & 6,740 & 25,216 & 21,000 \\
\hline Placer thawfield & 227,000 & 130,000 & 300,000 & 210,000 & 105,000 & 130,000 & 65,000 & $\ldots$ & $\ldots$ \\
\hline Placer subtotal & 259,400 & 180,250 & 452,000 & $\mathbf{3 0 7 , 2 5 0}$ & 183,930 & 181,247 & 71,740 & 25,216 & 21,000 \\
\hline Coal subtotal & 28,800 & 19,900 & 26,150 & 38,670 & 18,195 & 16,894 & 12,875 & -- & 8,168 \\
\hline Hardrock (core) & - & 95,600 & 223,630 & 242,440 & 648,600 & 205,805 & 211,812 & 124,325 & 347,018 \\
\hline Hardrock (rotary) & - & 19,500 & 130,220 & 89,790 & 112,355 & 110,850 & 148,022 & 127,990 & 91,692 \\
\hline Hardrock subtotal & 50,200 & 115,100 & 353,850 & 332,230 & 760,955 & 316,655 & 359,834 & 252,315 & $438,710^{b}$ \\
\hline TOTAL (feet) & 338,400 & 315,250 & 832,000 & 678,170 & 963,080 & 514,796 & 444,449 & 277,531 & 467,878 \\
\hline TOTAL (meters) & 103,144 & 96,088 & 253,593 & 206,700 & 293,547 & 156,910 & 135,502 & 84,591 & 141,781 \\
\hline
\end{tabular}

${ }^{a}$ Does not included 756,000 feet of rotary blast-hole drilling in 1993 .

bIncludes 236,803 underground coring.

- - Not reported. 
Table 17. Drilling footage by region in Alaska, 1994

\begin{tabular}{|c|c|c|c|c|c|c|c|c|}
\hline Type of drilling & Northern & Western & $\begin{array}{c}\text { Eastern } \\
\text { interior }\end{array}$ & $\begin{array}{l}\text { South- } \\
\text { central }\end{array}$ & $\begin{array}{l}\text { South- } \\
\text { western }\end{array}$ & $\begin{array}{c}\text { Alaska } \\
\text { Peninsula }\end{array}$ & $\begin{array}{l}\text { South- } \\
\text { eastern }\end{array}$ & TOTAL \\
\hline Placer exploration & 13,000 & $\cdots$ & 8,000 & $\cdots$ & $\cdots$ & $\cdots$ & $\cdots$ & 21,000 \\
\hline Placer thawfield & - - & -. & -. & $\cdots$ & $\cdots$ & $\cdots$ & $\cdots$ & - \\
\hline Placer subtotal & 13,000 & -- & 8,000 & -- & -- & $\cdots$ & -- & 21,000 \\
\hline Coal subtotal & 6,668 & -- & 1,500 & -- & - & $\cdots$ & $\cdots$ & 8,168 \\
\hline Hardrock core & $\cdots$ & 61,773 & 9,542 & 4,200 & 23,000 & $\cdots$ & 248,503 & 347,018 \\
\hline Hardrock rotary & -. & 20,000 & 66,692 & 5,000 & -. & $\cdots$ & -- & 91,692 \\
\hline Hardrock subtotal & -. & 81,773 & 76,234 & 9,200 & 23,000 & $\cdots$ & 248,503 & $438,710^{\mathrm{a}}$ \\
\hline TOTAL (feet) & 19,668 & 81,773 & 85,734 & 9,200 & 23,000 & $\cdots$ & 248,503 & 467,878 \\
\hline TOTAL (meters) & 5,960 & 24,780 & 25,980 & 2,788 & 6,970 & - & 75,304 & 141,781 \\
\hline
\end{tabular}

- - Not reported.

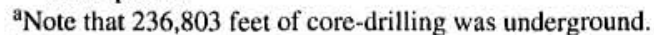

\section{METAL AND MINERAL PRODUCT RECYCLING INDUSTRY}

Alaska's 1994 metal and mineral product recycling industry continued at about the same levels as in 1993. Total value was estimated at $\$ 5.9$ million in 1994 , compared with about $\$ 6.3$ million in 1993 (table 18). The industry employed about 55 people on a yearround basis statewide. Volume of nonferrous scrap exported from Alaska declined from 2,651 tons (2,405 tonnes) in 1993 to 2,518 tons (2,284 tonnes) in
1994, a decline of 5 percent. However, improving copper, aluminum, and lead recycling prices resulted in a value increase for nonferrous metal from $\$ 3.5$ million in 1993 to $\$ 4.0$ million in 1994 , an increase of 14 percent (table 18). Both the value and volume of ferrous scrap decreased about 27 percent, mainly due to a reduction in ferrous scrap deliveries from the North Slope petroleum fields.

Table 18. Reported scrap metal and mineral-based recyclable products exported from Alaska, 1992-94a

\begin{tabular}{|c|c|c|c|c|c|c|}
\hline \multirow[b]{2}{*}{ Commodity } & \multicolumn{2}{|c|}{$\begin{array}{c}1993 \\
\text { Quantity }\end{array}$} & \multirow{2}{*}{$\begin{array}{l}\text { Estimated } \\
\text { value }^{b}\end{array}$} & \multicolumn{2}{|c|}{$\begin{array}{l}1994 \\
\text { Quantity }\end{array}$} & \multirow{2}{*}{$\begin{array}{c}\text { Estimated } \\
\text { value }\end{array}$} \\
\hline & pounds & kilograms & & pound & kilograms & \\
\hline \multicolumn{7}{|l|}{ Nonferrous scrap } \\
\hline Aluminum & $2,526,664$ & $1,146,095$ & $\$ 1,617,064$ & $2,423,669$ & $1,099,376$ & $\$ 1,866,078$ \\
\hline Brass & 110,795 & 50,257 & 243,749 & 160,724 & 72,904 & 353,593 \\
\hline Copper & 582,680 & 264,304 & 635,121 & 678,354 & 307,701 & 915,778 \\
\hline Lead $^{c}$ & $1,701,700$ & 771,891 & 252,306 & $1,750,000$ & 793,800 & 612,500 \\
\hline Radiators & 11,696 & 5,307 & 35,088 & 15,492 & 7,027 & 46,476 \\
\hline Stainless steel & 11,253 & 5,104 & 56,265 & 7,510 & 3,406 & 37,550 \\
\hline \multicolumn{7}{|l|}{ Undistributed } \\
\hline nonferrous scrap & 356,420 & 161,672 & 712,840 & - & $\cdots$ & $\ldots$ \\
\hline Subtotal & $5,301,208$ & $2,404,630$ & $\$ 3,552,433$ & $5,035,749$ & $2,284,214$ & $\$ 3,831,975$ \\
\hline Ferrous serap & $63,656,860$ & $28,874,751$ & $2,705,416$ & $51,046,000$ & $23,154,466$ & $2,083,860$ \\
\hline Glass & $1,034,000$ & 469,022 & N/A & 532,000 & 241,315 & N/A \\
\hline Plastic (HDPE\#2) & $\cdots$ & $\cdots$ & - & 20,000 & 9,072 & N/A \\
\hline TOTAL & $69,992,068$ & $31,748,403$ & $\$ 6,257,849$ & $56,633,749$ & $25,689,067$ & $\$ 5,915,835$ \\
\hline $\begin{array}{l}{ }^{\text {a }} \text { All production data in } \\
\text { (Fairbanks), Alaska } \\
\text { (Anchorage), ABS } \\
\text { bValue estimates deter } \\
\text { estimates provided } \\
\text { cLead volume estimate } \\
\text { - - Not reported. }\end{array}$ & $\begin{array}{l}1993 \text { and } 19 \\
\text { Metals Recyc } \\
\text { laskan (Fairb } \\
\text { mined from b } \\
y \text { individual } \\
\text { s judged to b }\end{array}$ & $\begin{array}{l}\text { ed by K \& K } \\
\text { horage), Anc } \\
\text { d United Bat } \\
\text { and } 1994 \text { cor } \\
\text { ers. We emp } \\
\text { ative for both }\end{array}$ & $\begin{array}{l}\text { ling Inc. (Fair } \\
\text { Recycling C } \\
\text { rvices (Portla } \\
\text { ty prices of ret } \\
\text { that price estir }\end{array}$ & $\begin{array}{l}\text { ackovich Cor } \\
\text { chorage), Ba } \\
\text { on). } \\
\text { al or scrap as } \\
\text { not include } \mathrm{tr}\end{array}$ & $\begin{array}{l}\text { and Industri } \\
\text { cialist (Anch } \\
\text { in Mining Jo } \\
\text { ion, preparati }\end{array}$ & $\begin{array}{l}\text { y Inc. } \\
\text { P Exploration } \\
\text { d from } \\
\text { fining costs. }\end{array}$ \\
\hline
\end{tabular}


Most Alaska scrap dealers benefited from a sharp increase in copper and aluminum prices in the fourth quarter of 1994, and aluminum shipments in particular are expected to be brisk in 1995.

Improving lead prices allowed virtually all scrap dealers surveyed to expand their lead-acid battery collection efforts, although the amount of lead reported to be shipped from the state remained at almost the same level for both 1993 and 1994, a yearly average of 863 tons ( 783 tonnes) of lead. Despite the drop in 1994 production, ferrous scrap demand from the nations of the Pacific Rim continued to be strong.

$\mathrm{K}$ \& K Recycling Inc. ( $\mathrm{K}$ \& $\mathrm{K}$ ) continued to lead Alaska metal recycling efforts in the interior region. The company processed 361,618 pounds ( 164,030 kilograms) of nonferrous scrap and $1,637,797$ pounds $(742,900$ kilograms) of ferrous scrap, down about onethird in both categories from 1993 levels due mainly to a drop in aluminum can and Fairbanks area ferrous scrap dealerships. Most nonferrous scrap handled by $\mathrm{K} \& \mathrm{~K}$ is shipped by tractor-trailer to dealers outside Alaska, and the ferrous scrap is usually shipped via the Alaska Railroad Corporation to the coast.

Nonferrous metal, glass, and plastics recycling in southcentral Alaska was again dominated by the Anchorage Recycling Center (ARC) of Anchorage (fig. 31). ARC recycled 2,608,000 pounds $(1,182,990$ kilograms) of nonferrous scrap and all the glass and plastic reused in Alaska (table 18). ARC continued to research the use of glass and plans to market crushed glass for solid-waste disposal systems and other "clean aggregate" applications. Although overall aluminum recycling volumes were down from 1993 to 1994, ARC sponsored the "Great Aluminum Can Roundup" in Anchorage area schools and collected approximately 40,000 pounds $(18,144$ kilograms $)$ of aluminum in 1994, nearly double the amount collected in 1993. BP Exploration recycled more than 1,783 pounds ( 809 kilograms) aluminum at BP facilities in Anchorage and on the North Slope; proceeds from the sale of the aluminum were given to Covenant House in Anchorage.

Alaska Metals Recycling of Anchorage baled and shipped 20,180 tons $(18,202$ tonnes) of ferrous scrap to Japan, about the same amount shipped by the company to markets in Taiwan in the last two previous years. BP Exploration recycled 4,600 tons (4,173 tonnes) of ferrous scrap, including spent drill steel, from their facilities on the North Slope.

ABS Alaska continued to ship spent lead-acid batteries from its battery manufacturing plant in Fairbanks to processing plants in California. This battery recycling accounted for about 30 percent of the statewide lead recycling total (table 18).

United Battery Systems (UBS) of Portland Oregon and its Anchorage subsidiary, Battery Specialists Inc., hauled most of the remaining lead-acid batteries, about $1,200,000$ pounds $(544,320$ kilograms $)$, to processing plants outside the state. Both firms coordinate the collection of batteries from many bush communities and the North Slope.

Most metal recycling companies believed that their businesses would increase scrap shipments from Alaska in 1995, citing fundamental improvements in market demand for both ferrous and nonferrous scrap. Although many in the general public view the metal and minerals recycling business as an environmental cleanup effort, much of the ferrous scrap and selected nonferrous commodities are profitably recovered by Alaska small businesses. In addition, some firms incorporate valueadded components such as lead-acid batteries to be sold here in Alaska.

\section{GOVERNMENT ACTION}

On May 5, 1994, Fairbanks Gold Mining Inc. (FGMI) received a Clean Water Act Section 404 (wetlands) permit from the Corps of Engineers for its Fort Knox Mine. This permit was the last major federal requirement, and in November FGMI started to clear the vegetation and overburden from the pit area, the conveyor and millsite, the tailings dam, and the fresh water reservoir. Fort Knox is the first major hardrock mine to be permitted on state-owned land.

The Healy Clean Coal Project southwest of Fairbanks also received the last permit necessary to begin construction in June 1994, but work at the site had to be delayed until 1995.

Permits were also a prominent feature of the activity at the Alaska-Juneau (A-J) and Kensington Mines near Juneau. The U.S. Environmental Protection
Agency (EPA) issued a Technical Assistance Report for the Kensington Mine that and owners have said the report detected no fatal flaws. However, the EPA report concluded that the tailings dam at the A-J Mine, as designed, would harm water quality or wildlife. Echo Bay Alaska Inc., owner of the A-J, is investigating alternatives to the Sheep Creek tailings impoundment.

The Alaska Mineral's Commission made several recommendations in its 1994 report to the Governor and legislature about legislation needed to enhance mineral development. Some of these suggestions were submitted to the legislature for consideration, and two House Bills were enacted into law.

House Bill 132 is "An act to extend the time period of all permits issued by the state relating to the extraction or removal of resources if the holder of the permits, 
or any of the agencies issuing a permit to the holder, is involved in litigation concerning the issuance of validity of any permit related to the extraction or removal." Any mining operation will require several permits, with differing term limits, so that one or more permits can expire during the course of prolonged litigation. Rather than have the permitee reapply for expired permits, this legislation allows the clock to stop until the permit can be used.

House Bill 333 is "An Act amending the Alaska Land Act to define the term 'state selected land' for the purpose of recognizing mining locations and giving retrospective effect to the amendment; and providing for an effective date." This Act recognizes that there is a period of time between the State selecting the 103 million acres (41.7 million hectares) of unencumbered federal land promised to the state as an entitlement under the Statehood Act and the actual transfer of title to that land. From the time of selection, no federal mining claims may be located, and because the state has no ownership rights to the land until the federal government grants tentative approval of the selection, the state was unable to accept state mining claims. This problem was recently compounded when the federal government began to charge $\$ 100$ per federal claim per year as a rental fee for federal claims. Many of the owners of federal claims in areas surrounded by state-selected land expressed the desire to convert their federal claims to state claims.

Taxes in Alaska include the municipal taxes, the State Mining License Tax, and the Federal and State Corporate Income Tax. Table 19 summarizes taxes paid by the mining industry (excluding the state corporate income tax) to the State of Alaska during the last four calendar years. Recent changes in state tax law prevent municipalities from taxing in-situ resources, but fixed assets and goods may be taxed.

The final land selections of its 103-million-acre (41.7-million-hectare) entitlement were filed by the state in 1994.

At the request of the Fairbanks Industrial Development Corporation, the legislature appropriated $\$ 400,000$ to allow the State Division of Geological \& Geophysical Surveys to conduct aeromagnetic and electromagnetic surveys of the Fairbanks and Richardson mining districts during 1994. The maps containing the results of the surveys were released on February 7, 1995.

The Division of Mining \& Water Management, presented the first annual Reclamation of the Year award to John E. McClain of The Mining Company for outstanding work on Ester Creek west of Fairbanks. Certificates of Recognition were awarded to Fairbanks district miners Jack and Greg Neubauer of Cassiterite Placers Inc. for their work on Fox Creek, and to Alf Hopen for his reclamation of Little Eldorado Creek. John Brown received the same award for his work on the North Fork of Harrison Creek in the Circle district, and Doug Clarke won similar recognition of his reclamation in the Upper Chena drainage. The State will annually recognize responsible miners for exemplary work in returning disturbed ground to a useful condition as required by State law.

Table 19. Revenues paid to the State of Alaska by Alaska's mineral industry, 1991-94a

\begin{tabular}{|c|c|c|c|c|}
\hline & 1991 & 1992 & 1993 & 1994 \\
\hline State claim rentals & $\$ 626,164$ & $\$ 537,355$ & $\$ 523,661$ & 709,568 \\
\hline Production royalties & 11,736 & 7,815 & 7,917 & 12,015 \\
\hline Mining license & 598,971 & 465,163 & 425,607 & 481,907 \\
\hline \multicolumn{5}{|c|}{ Coal rents and royalties } \\
\hline Royalties & $\$ 1,188,063$ & $\$ 1,294,825$ & $\$ 1,486,100$ & $1,399,912$ \\
\hline Rents & 130,363 & 198,835 & 198,835 & 198,835 \\
\hline Subtotal & $1,318,426$ & $1,493,660$ & $1,684,935$ & $1,598,747$ \\
\hline \multicolumn{5}{|l|}{ Material sales } \\
\hline Mental Health & 34,141 & 104,845 & 5,300 & 54,772 \\
\hline Division of Land & 706,220 & 491,235 & 561,414 & 174,484 \\
\hline SPCO & 0 & 161,408 & 150,000 & 136,752 \\
\hline School fund & 3,548 & 3,279 & 3,011 & 1,564 \\
\hline Subtotal & 743,911 & 760,769 & 719,725 & 367,571 \\
\hline Total & $\$ 3,299,208$ & $\$ 3,264,752$ & $\$ 3,361,845$ & $\$ \mathbf{3 3 , 1 6 9 , 8 0 9}$ \\
\hline
\end{tabular}




\section{ALASKA MENTAL HEALTH LANDS SETTLEMENT}

The Alaska Mental Health Lands litigation reached an interim solution in 1994. The legal action against the state halted lease and purchase transfers of millions of acres of mineralized Alaska state lands. The settlement awarded cash for surface values and reconstructed most of the original one-million-acre Alaska Mental Health Lands Trust.

\section{BRIEF HISTORY OF ALASKA MENTAL HEALTH LANDS TRUST}

In 1956, before statehood, the Territory of Alaska was given the one-million-acre (404,690 hectare) Alaska Mental Health Lands Trust (AMHLT), which was a component of the Alaska Mental Health Enabling Act. The trust was confirmed and incorporated into the 1959 Alaska Statehood Act, which instructed the state to manage trust lands in order to generate revenues for mentally disabled Alaska citizens. In 1978 the Alaska Legislature abolished the AMHLT. Subsequently, the Alaska Department of Natural Resources (DNR) sold, leased, or classified as special-use areas more than half the AMHLT lands.

\section{WEISS V. STATE OF ALASKA}

In 1984 an Alaska Superior Court decision (Weiss v. State of Alaska) ruled that the Alaska Mental Health Lands trust had been illegally dissolved by the Alaska legislature. In 1985 this decision was upheld by the Alaska Supreme Court. The courts ordered the state to reconstitute AMHLT as nearly as possible to the original form and reimburse the trust for lands that had been sold or leased. Both compensations were to be offset by mental-health expenditures made by the State of Alaska since 1978.

Notable mineral projects potentially affected by the litigation included the Wishbone Hill (Idemitsu), Beluga (DRven Corporation), and Healy (Usibelli) coal deposits, and the Fort Knox gold mine (Fairbanks Gold Mining Inc.).

\section{CHAPTER 66 SETTLEMENT}

In 1991 the Hickel administration introduced the Chapter 66 Settlement, which would reconstitute remaining AMHLT lands (about 480,000 acres, [194,260 hectares]) and add to the Trust new hypothecated (pledged as security) lands that were judged to be of equal value to the Trust lands that had been disposed of by the state. In 1993, the Superior Court rejected portions of the Chapter 66 Settlement in part because a cash settlement was not included. In addition, the Chapter 66 Settlement did not reconstitute the AMHLT land base as had been specifically instructed by previous court rulings.

\section{INTERIM RESOLUTION REACHED IN 1994}

During the spring of 1994, DNR combined the expertise of the Division of Mining \& Water Management (DMWM), the Division of Lands (DOL), and the Division of Geological \& Geophysical Surveys (DGGS) to help resolve the disputed land settlement.

In order to replace lands of equal value that were removed from the Mental Health Land Trust as ordered by the courts, DGGS systematically evaluated the mineral endowment of several proposed replacementland tracts. To complete these evaluations, DGGS used modern methods of determining and estimating the probable value of in-place mineral resources in the replacement land tracts.

DMWM picked about 202,000 acres $(81,820$ hectares) of replacement tracts in the Haines-Skagway, Salcha-Chena, and Ophir areas of southeastern, eastern interior, and southwestern Alaska for DGGS to analyze. In addition, DMWM successfully argued to the court that modifications should be made to mineral-value assumptions used by the plaintiffs representing the Trust in Weiss v. State of Alaska in placing value on lost AMHLT lands. DOL served as project manager of the entire effort and closely monitored the evaluation process.

As a result of the mineral-resource evaluation study, a new settlement proposal was crafted as House Bill 201 and passed by the Alaska Legislature. Governor Hickel signed the bill into law during the first special session of 1994. This legislation mandated the following:

1. Established a trust for mental health programs that awarded $\$ 200$ million for surface estate values, and a reconstituted land base of 960,000 acres $(388,610$ hectares). About half the land base, 480,000 acres $(194,300$ hectares), was original mental health lands and the other half was reconstituted lands packaged by the Department of Natural Resources team.

2. Established a Mental Health Trust Authority to oversee the AMHLT assets.

3. Recommended development policy.

4. Created a separate unit in the Department of Natural Resources to manage the Alaska Mental Health Lands Trust lands on behalf of the newly created Mental Health Trust Authority. 
On July 29, 1994, in the Superior Court in Fairbanks, Justice Mary Greene granted preliminary approval of the AMHLT settlement crafted by the state and passed by the legislature. However the court noted that several problems should be solved before final court approval would be granted. The problems were: (1) monies raised by state land contracts were less than anticipated in the AMHLT legislation that was enacted 1994 , (2) the court recommended that parts of the Chena-Salcha replacement tract would not be included in the settlement, and (3) errors and omissions in the settlement package needed correction. The Superior court also recommended that the state close all remaining settlement lands to mineral entry.

To address the problems identified by Superior Court Justice Mary Greene, Governor Hickel called a second Special Session of the Alaska Legislature on September 26, 1994. A new bill, Senate Bill 383, added new replacement lands as identified by DNR and removed others recommended by the court for exclusion. Senate Bill 383 was passed on September 28, 1994, and provided for a net gain of about 66,746 acres $(27,020$ hectares) to the settlement. This action brought the new total land trust package to 995,502 acres (402,980 hectares). Senate Bill 383 also instructed DNR to close all remaining open AMHLT lands to mineral entry.

In October 1994, DNR issued land orders that explained the impact of the legislatively ordered mineral closures and provided descriptions of the new lands added to the Trust.

On December 14, Superior Court Justice Mary Greene issued her "Memorandum Decision and Order Granting Final Approval to House Bill 210 Settlement. This court action (1) dissolved a 1992 court injunction, (2) vacated a 1986 court-ordered Mineral Closing Order on all original Mental Health Lands, and (3) dismissed the Weiss v. State of Alaska lawsuit. Judge Greene upheld the temporary Mineral Closing Order ratified by Senate Bill 383 in September until regulations regarding their development were in place. Judge Greene's ruling set the deadline for appeal as January 13, 1995. Plaintiffs of the Mental Health Lands Trust filed an appeal on the day of the deadline and provided their Statement of Reasons detailing their arguments against Judge Greene's December 1994 decision on January 27, 1995. No date for hearing this appeal has been issued at the time of this writing.

The map inside the back cover shows generalized locations of Mental Health Trust Lands in Alaska.

\section{REFERENCES CITED}

Alaska Department of Natural Resources Land Records Information Section, 1994, Reconstitution of the Mental Health Trust and confirmation and ratification of conversion of certain original mental health land to general grant land: Statewide Index Map, scale $1: 4,608,000$.

Apel, D.G., 1995, Geology of the Greens Creek Mine, Admiralty Island, Alaska, in Albanese, Mary, ed., Conference Juneau Abstracts of Professional Papers: Alaska Miner's Association Juneau Branch Special Report, p. 35-36.

Bundtzen, T.K., 1981, Geological guides to heavy mineral placers, in Campbell, B.W. and Finch, L., eds., Second Annual Conference on Alaskan Placer Mining-Focus: gold, University of Alaska Mineral Industry Research Laboratory Report 46, p. 21-45.

Bundtzen, T.K., Swainbank, R.C., Clough, A.H., Henning, M.W., and Hansen, E.W., 1994, Alaska's mineral industry report 1993: Alaska Division of Geological \& Geophysical Surveys Special Report 48 , p. 24.
Ellis, Roger, 1995, Lead and zinc-better times ahead, in Mining Journal, v. 324, no. 8315, p. 149-151.

Environmental Protection Agency, December 30, 1994, News release number 94-103.

Hoffman, Vivian, and Albanese, Thomas, 1995, Cooperative relationships between the Greens Creek Mine and the U.S. Forest Service-Two examples, in Albanese, Mary, ed., Conference Juneau Abstracts of Professional Papers, Alaska Miners Association Juneau Branch Special Publication, p. 15.

Miller, M.L., and Bundtzen, T.K., 1994, Generalized geologic map of the Iditarod Quadrangle, Alaska, showing potassium argon, major oxide, trace element, fossil, paleocurrent, and archeological sample localities: U.S. Geological Survey Map MF-2219A, 48 p., 1 sheet, scale 1:250,000.

Thomas, Andrew, 1995, Major gold project, in Mining Magazine, v. 172 , no. 6, p. 344-347.

U.S. Bureau of Mines, 1993, U.S. customary units/ metric units conversion chart in Minerals Today, February 1993, Washington D.C., p. 4. 
APPENDIX A

Total active claims and new claims staked in 1992, 1993, and 1994

(listed by quadrangle) ${ }^{\mathrm{b}}$

Compiled by Erik Hansen

\begin{tabular}{|c|c|c|c|c|c|c|c|c|c|c|c|c|c|}
\hline & \multirow[b]{2}{*}{ Quadrangle } & \multicolumn{3}{|c|}{$\begin{array}{c}\text { Active claims } \\
\text { assessment work }\end{array}$} & \multicolumn{6}{|c|}{ New claims staked } & \multicolumn{3}{|c|}{$\begin{array}{c}\text { Total } \\
\text { active claims }\end{array}$} \\
\hline & & 1992 & 1993 & 1994 & 1992 & 1993 & 1994 & 1992 & 1993 & 1994 & 1992 & 1993 & 1994 \\
\hline 13 & Umiat & 0 & 0 & 0 & 0 & 0 & 0 & 0 & 0 & 0 & $\mathbf{0}$ & $\mathbf{0}$ & $\mathbf{0}$ \\
\hline 14 & Sagavanirktok & 0 & 0 & 0 & 0 & 0 & 0 & 0 & 0 & 0 & $\mathbf{0}$ & 0 & 0 \\
\hline 15 & Mt. Michelson & 0 & 0 & 0 & 0 & 0 & 0 & 0 & 0 & 0 & $\mathbf{0}$ & 0 & 0 \\
\hline 17 & Point Hope & 0 & 0 & 0 & 0 & 0 & 0 & 0 & 0 & 0 & 0 & $\mathbf{0}$ & 0 \\
\hline 18 & De Long Mts. & 1,384 & 661 & 760 & 0 & 0 & 0 & 0 & 0 & 144 & 1,384 & 661 & 904 \\
\hline 23 & Philip Smith Mts. & 3 & 2 & 1 & 0 & 0 & 0 & 0 & 0 & 0 & 3 & 2 & 1 \\
\hline 26 & Noatak & 66 & 0 & 0 & 0 & 0 & 0 & 0 & 0 & 0 & 66 & 0 & 0 \\
\hline 27 & Baird Mts. & 125 & 7 & 7 & 0 & 0 & 0 & 0 & 0 & 0 & 125 & 7 & 7 \\
\hline 28 & Ambler River & 117 & 71 & 68 & 0 & 0 & 0 & 0 & 5 & 189 & 117 & 76 & 257 \\
\hline 29 & Survey Pass & 32 & 34 & 34 & 0 & 0 & 0 & 0 & 0 & 0 & 32 & 34 & 34 \\
\hline 30 & Wiseman & 1,279 & 962 & 851 & 4 & 278 & 39 & 48 & 5 & 55 & 1,331 & 1,245 & 945 \\
\hline 31 & Chandalar & 548 & 394 & 270 & 0 & 9 & 9 & 16 & 16 & 21 & 564 & 419 & 300 \\
\hline 32 & Christian & 1 & 1 & 0 & 0 & 0 & 0 & 0 & 0 & 0 & 1 & 1 & 0 \\
\hline 35 & Kotzebue & 13 & 28 & 28 & 0 & 0 & 0 & 15 & 15 & 0 & 28 & 43 & 28 \\
\hline 36 & Selawik & 0 & 0 & 0 & 0 & 0 & 0 & 0 & 0 & 0 & 0 & 0 & 0 \\
\hline 37 & Shungnak & 22 & 0 & 0 & 0 & 0 & 0 & 0 & 0 & 0 & 22 & 0 & 0 \\
\hline 38 & Hughes & 54 & 54 & 54 & 0 & 0 & 0 & 0 & 0 & 0 & 54 & 54 & 54 \\
\hline 39 & Bettles & 266 & 136 & 12 & 0 & 10 & 15 & 0 & 0 & 6 & 266 & 146 & 33 \\
\hline 43 & Teller & 327 & 258 & 143 & 0 & 0 & 0 & 0 & 0 & 0 & 327 & 258 & 143 \\
\hline 44 & Bendeleben & 792 & 530 & 401 & 0 & 0 & 0 & 15 & 13 & 4 & 807 & 543 & 405 \\
\hline 45 & Candle & 433 & 313 & 351 & 0 & 0 & 0 & 20 & 4 & 11 & 453 & 317 & 362 \\
\hline 47 & Melozitna & 85 & 49 & 65 & 0 & 0 & 0 & 0 & 24 & 6 & 85 & 73 & 71 \\
\hline 48 & Tanana & 1,025 & 929 & 550 & 0 & 0 & 0 & 66 & 70 & 177 & 1,091 & 999 & 727 \\
\hline 49 & Livengood & 2,740 & 3,049 & 2,955 & 0 & 33 & 0 & 288 & 153 & 146 & 3,028 & 3,235 & 3,101 \\
\hline 50 & Circle & 3,386 & 2,440 & 2,675 & 0 & 0 & 0 & 520 & 477 & 256 & 3,906 & 2,917 & 2,931 \\
\hline 51 & Charley River & 183 & 178 & 32 & 0 & 0 & 0 & 0 & 0 & 0 & 183 & 178 & 32 \\
\hline 52 & Nome & 420 & 67 & 115 & 23 & 4 & 0 & 30 & 11 & 43 & 473 & 82 & 158 \\
\hline 53 & Solomon & 360 & 117 & 216 & 0 & 0 & 0 & 12 & 8 & 56 & 372 & 125 & 272 \\
\hline 54 & Norton Bay & 110 & 0 & 0 & 0 & 0 & 0 & 0 & 0 & 0 & 110 & 0 & 0 \\
\hline 55 & Nulato & 1,631 & 1,591 & 1,588 & 0 & 0 & 0 & 0 & 5 & 0 & 1,631 & 1,596 & 1,588 \\
\hline 56 & Ruby & 768 & 668 & 444 & 0 & 0 & 0 & 30 & 27 & 29 & 798 & 695 & 473 \\
\hline 57 & Kantishna River & 80 & 44 & 44 & 58 & 0 & 0 & 0 & 0 & 0 & 138 & 44 & 44 \\
\hline 58 & Fairbanks & 1,518 & 2,260 & 2,670 & 0 & 0 & 0 & 131 & 195 & 143 & 1,649 & 2,455 & 2,813 \\
\hline 59 & Big Delta & 2,842 & 2,902 & 2,652 & 88 & 0 & 0 & 363 & 213 & 408 & 3,293 & 3,115 & 3,060 \\
\hline 60 & Eagle & 1,448 & 968 & 1,048 & 0 & 0 & 0 & 131 & 170 & 171 & 1,579 & 1,138 & 1,219 \\
\hline 63 & Unalakleet & 0 & 0 & 0 & 0 & 0 & 0 & 0 & 0 & 0 & 0 & 0 & 0 \\
\hline 64 & Ophir & 342 & 362 & 290 & 0 & 0 & 0 & 61 & 15 & 109 & 403 & 377 & 399 \\
\hline 65 & Medfra & 255 & 254 & 285 & 0 & 0 & 0 & 0 & 2 & 30 & 255 & 256 & 315 \\
\hline 66 & Mt. McKinley & 238 & 273 & 93 & 0 & 0 & 0 & 0 & 2 & 0 & 238 & 275 & 93 \\
\hline 67 & Healy & 3,001 & 1,629 & 1,228 & 12 & 0 & 0 & 44 & 90 & 195 & 3,057 & 1,719 & 1,423 \\
\hline 68 & Mt. Hayes & 1,678 & 1,207 & 1,049 & 2 & 0 & 12 & 2 & 80 & 163 & 1,682 & 1,287 & 1,224 \\
\hline 69 & Tanacross & 520 & 374 & 316 & 0 & 0 & 0 & 101 & 14 & 18 & 621 & 388 & 334 \\
\hline 72 & Holy Cross & 12 & 6 & 6 & 0 & 0 & 0 & 0 & 0 & 0 & 12 & 6 & 6 \\
\hline 73 & Iditarod & 568 & 222 & 262 & 3 & 6 & 0 & 11 & 0 & 13 & 582 & 228 & 275 \\
\hline 74 & McGrath & 290 & 75 & 75 & 0 & 0 & 0 & 0 & 0 & 0 & 290 & 75 & 75 \\
\hline 75 & Talkeetna & 940 & 869 & 728 & 2 & 0 & 0 & 183 & 68 & 120 & 1,125 & 937 & 848 \\
\hline 76 & Talkeetna Mts. & 723 & 514 & 525 & 1 & 0 & 0 & 117 & 61 & 45 & 841 & 575 & 570 \\
\hline 77 & Gulkana & 17 & 3 & 3 & 0 & 0 & 0 & 0 & 2 & 0 & 17 & 5 & 3 \\
\hline 78 & Nabesna & 337 & 191 & 96 & 0 & 0 & 0 & 0 & 0 & 0 & 337 & 191 & 96 \\
\hline 81 & Russian Mission & 43 & 40 & 40 & 0 & 0 & 0 & 0 & 0 & 0 & 43 & 40 & 40 \\
\hline 82 & Sleetmute & 158 & 109 & 122 & 0 & 0 & 0 & 0 & 0 & 8 & 158 & 109 & 130 \\
\hline 83 & Lime Hills & 12 & 12 & 14 & 0 & 0 & 0 & 0 & 0 & 2 & 12 & 12 & 16 \\
\hline
\end{tabular}

"Total count based on all documents recorded through January 1, 1994.

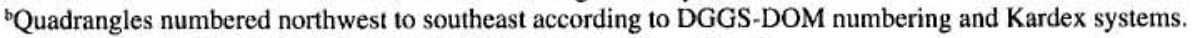

'Excluding an undetermined number of claims on state-selected land. 
APPENDIX A-Continued

\begin{tabular}{|c|c|c|c|c|c|c|c|c|c|c|c|c|c|}
\hline & \multirow[b]{2}{*}{ Quadrangle } & \multicolumn{3}{|c|}{$\begin{array}{l}\text { Active claims } \\
\text { assessment work }\end{array}$} & \multicolumn{6}{|c|}{ Federal New claims staked } & \multicolumn{3}{|c|}{$\begin{array}{c}\text { Total } \\
\text { active claims }\end{array}$} \\
\hline & & 1992 & 1993 & 1994 & 1992 & 1993 & 1994 & 1992 & 1993 & 1994 & 1992 & 1993 & 1994 \\
\hline 84 & Tyonek & 4,200 & 4,713 & 2,112 & 0 & 0 & 0 & 82 & 67 & 0 & 4,282 & 4,780 & 2,112 \\
\hline 85 & Anchorage & 596 & 441 & 367 & 7 & 0 & 3 & 78 & 64 & 56 & 681 & 505 & 426 \\
\hline 86 & Valdez & 341 & 25 & 41 & 0 & 0 & 0 & 18 & 0 & 2 & 359 & 25 & 43 \\
\hline 87 & McCarthy & 187 & 209 & 132 & 0 & 0 & 0 & 0 & 0 & 0 & 187 & 209 & 132 \\
\hline 91 & Bethel & 43 & 35 & 48 & 0 & 0 & 0 & 0 & 4 & 1 & 43 & 39 & 49 \\
\hline 92 & Taylor Mts. & 246 & 90 & 94 & 0 & 0 & 0 & 2 & 0 & 0 & 248 & 90 & 94 \\
\hline 93 & Lake Clark & 295 & 335 & 335 & 0 & 0 & 0 & 1 & 0 & 66 & 296 & 335 & 401 \\
\hline 94 & Kenai & 11 & 12 & 3 & 0 & 0 & 0 & 0 & 0 & 0 & 11 & 12 & 3 \\
\hline 95 & Seward & 1,322 & 157 & 586 & 67 & 95 & 51 & 13 & 13 & 32 & 1,402 & 265 & 669 \\
\hline 96 & Cordova & 1 & 0 & 0 & 3 & 0 & 0 & 1 & 0 & 0 & 5 & 0 & 0 \\
\hline 97 & Bering Glacier & 255 & 390 & 152 & 0 & 0 & 0 & 0 & 0 & 1 & 255 & 390 & 153 \\
\hline 101 & Goodnews & 0 & 0 & 0 & 0 & 0 & 0 & 0 & 0 & 0 & $\mathbf{0}$ & $\mathbf{0}$ & $\mathbf{0}$ \\
\hline 102 & Dillingham & 0 & 0 & 0 & 0 & 0 & 0 & 0 & 0 & 219 & $\mathbf{0}$ & 0 & 219 \\
\hline 103 & Iliamna & 1,140 & 631 & 650 & 0 & 0 & 0 & 147 & 0 & 0 & 1,287 & 631 & 650 \\
\hline 104 & Seldovia & 10 & 10 & 7 & 0 & 0 & 0 & 0 & 0 & 2 & 10 & 10 & 9 \\
\hline 105 & Blying Sound & 0 & 0 & 0 & 0 & 0 & 0 & 0 & 0 & 0 & 0 & 0 & 0 \\
\hline 107 & Icy Bay & 0 & 0 & 10 & 0 & 0 & 0 & 6 & 14 & 0 & 6 & 14 & 10 \\
\hline 108 & Yakutat & 11 & 1 & 1 & 0 & 0 & 0 & 0 & 0 & 0 & 11 & 1 & 1 \\
\hline 109 & Skagway & 483 & 430 & 392 & 92 & 1 & 1 & 0 & 99 & 318 & 575 & 530 & 711 \\
\hline 111 & Mt. Fairweather & 1 & 2 & 2 & 0 & 0 & 0 & 0 & 0 & 0 & 1 & 2 & 2 \\
\hline 112 & Juneau & 2,663 & 1,399 & 1,509 & 58 & 76 & 27 & 25 & 20 & 3 & 2,746 & 1,495 & 1,539 \\
\hline 113 & Taku River & 0 & 0 & 0 & 0 & 0 & 0 & 0 & 00 & 0 & o & 0 & 0 \\
\hline 114 & Sitka & 171 & 57 & 47 & 27 & 8 & 39 & 4 & 0 & 0 & 202 & 65 & 86 \\
\hline 115 & Sumdum & 82 & 75 & 4 & 0 & 0 & 0 & 0 & 0 & 0 & 82 & 75 & 4 \\
\hline 116 & Port Alexander & 1 & 0 & 0 & 0 & 0 & 1 & 0 & 0 & 0 & 1 & 0 & 1 \\
\hline 117 & Petersburg & 532 & 180 & 193 & 51 & 19 & 1 & 0 & 0 & 0 & 583 & 199 & 194 \\
\hline 118 & Bradfield Canal & 500 & 45 & 33 & 2 & 0 & 0 & 0 & 0 & 0 & 502 & 45 & 33 \\
\hline 119 & Craig & 917 & 405 & 671 & 169 & 62 & 89 & 9 & 8 & 1 & 1,095 & 475 & 761 \\
\hline 120 & Ketchikan & 206 & 114 & 158 & 1 & 0 & 0 & 0 & 0 & 0 & 207 & 114 & 158 \\
\hline 121 & Dixon Entrance & 206 & 61 & 86 & 25 & 0 & 9 & 0 & 0 & 2 & 231 & 61 & 97 \\
\hline 122 & Prince Rupert & 0 & 0 & 0 & 0 & 0 & 0 & 0 & 0 & 0 & o & 0 & 0 \\
\hline 123 & Hagemeister Island & 216 & 196 & 196 & 0 & 0 & 0 & 0 & 0 & 0 & 216 & 196 & 196 \\
\hline 126 & Mt. Katmai & 0 & 0 & 0 & 0 & 0 & 0 & 0 & 0 & 0 & o & $\mathbf{0}$ & 0 \\
\hline 127 & Afognak & 2 & 2 & 1 & 0 & 0 & 45 & 0 & 0 & 0 & 2 & 2 & 46 \\
\hline 128 & Bristol Bay & 0 & 0 & 0 & 0 & 0 & 0 & 14 & 0 & 0 & 14 & 0 & o \\
\hline 130 & Karluk & 0 & 0 & 0 & 0 & 0 & 0 & 0 & 0 & 0 & 0 & 0 & 0 \\
\hline 133 & Chignik & 67 & 22 & 10 & 0 & 0 & 0 & 0 & 0 & 0 & 67 & 22 & 10 \\
\hline 135 & Trinity Islands & 115 & 92 & 79 & 0 & 0 & 0 & 2 & 8 & 1 & 117 & 100 & 80 \\
\hline 138 & Port Moller & 17 & 0 & 11 & 0 & 0 & 0 & 0 & 0 & 93 & 17 & 0 & 104 \\
\hline \multicolumn{2}{|c|}{ TOTAL } & 46,029 & 34,982 & 31,096 & 695 & 601 & 341 & 2,606 & 2,042 & 3,365 & 49,330 & 37,625 & 34,802 \\
\hline
\end{tabular}




\section{APPENDIX B}

1994 Prospecting sites on State lands

Compiled by Erik Hansen

\begin{tabular}{|c|c|c|c|c|}
\hline & Quadrangle & New sites & Extensions & Total \\
\hline 19 & Mishuguk Mtn. & 1 & 0 & 1 \\
\hline 27 & Baird Mtns. & 10 & 0 & 10 \\
\hline 30 & Wiseman & 7 & 8 & 15 \\
\hline 31 & Chandalar & 3 & 18 & 21 \\
\hline 44 & Bendeleben & 7 & 0 & 7 \\
\hline 47 & Melozitna & 7 & 0 & 7 \\
\hline 48 & Tanana & 41 & 7 & 48 \\
\hline 49 & Livengood & 82 & 22 & 104 \\
\hline 50 & Circle & 113 & 444 & $\mathbf{5 5 7}$ \\
\hline 52 & Nome & 13 & 22 & 35 \\
\hline 53 & Solomon & 9 & 3 & 12 \\
\hline 58 & Fairbanks & 45 & 5 & 50 \\
\hline 59 & Big Delta & 46 & 23 & 69 \\
\hline 60 & Eagle & 21 & 12 & 33 \\
\hline 64 & Ophir & 2 & 0 & 2 \\
\hline 65 & Medra & 0 & 8 & 8 \\
\hline 67 & Healy & 36 & 49 & 85 \\
\hline 68 & Mt. Hayes & 14 & 6 & 20 \\
\hline 69 & Tanacross & 169 & 16 & 185 \\
\hline 75 & Talkeetna & 4 & 15 & 19 \\
\hline 76 & Talkeetna Mtns. & 8 & 0 & 8 \\
\hline 83 & Lime Hills & 2 & 0 & 2 \\
\hline 84 & Tyonek & 6 & 18 & 24 \\
\hline 85 & Anchorage & 14 & 2 & 16 \\
\hline 86 & Valdez & 13 & 4 & 17 \\
\hline 103 & Iliamna & 4 & 0 & 4 \\
\hline 109 & Skagway & 8 & 16 & 24 \\
\hline 135 & Trinity Islands & 25 & 0 & 25 \\
\hline \multicolumn{2}{|c|}{ TOTAL } & 710 & 698 & 1,408 \\
\hline
\end{tabular}




\section{APPENDIX C \\ State and federal agencies and private interest groups involved in mineral development activities, 1994}

(Note: The 1995 Service Directory of the Alaska Miners Association lists technical and professional consultants and companies available for work in Alaska. The report is available for \$12 from the Association's Anchorage office.)

\section{STATE OF ALASKA AGENCIES}

DEPARTMENT OF COMMERCE AND ECONOMIC DEVELOPMENT

State Office Building, 9 th Fl.

P.O. Box 110800 (mailing)

Juneau, AK 99811-0800

(907) $465-2500$

Function: Promotes economic development in Alaska.

Division of Economic Development State Office Building, 9th Fl. P.O. Box 110804 (mailing) Juneau, AK 99811-0804 (907) 465-2017

751 Old Richardson Hwy., Suite 205 Fairbanks, AK 99701

(907) 452-7464

Function: Primary advocacy agency in state government for economic growth. Researches and publishes economic data on Alaska's mining industry. Provides information and assistance to new or developing businesses. Attracts capital investment by advertising Alaska's resource potential. Provides research staff aid for the Alaska Minerals Commission.

Office of International Trade

3601 C Street, Suite 798

Anchorage, AK 99503

(907) 561-5585

(907) $561-4577$ (fax)

Function: The Office of International Trade (OIT) encourages the development of new markets for Alaska resources; expands existing markets; locates sources of investment capital; increases the visibility of Alaska and its products in the international marketplace; and improves communication among members of the Alaska and international business community. OIT makes referrals and provides technical assistance to those interested in developing export markets for Alaskaproduced or value-added goods and services. OIT also has representation in Japan, Korea, Taiwan, and Russia.

DEPARTMENT OF ENVIRONMENTAL CONSERVATION

410 Willoughby Ave., Ste. 105

Juneau, AK 99801-1795

(907) 465-5010

Public Information (907) 465-5060
Function: Issues permits for activities, including mining, that affect air or water quality or involve land disposal of wastes. Sets air- and water-quality standards. Inspects, monitors, and enforces environmental quality statutes, regulations, and permits. Reviews all federal permits.

Northern Regional Office 610 University Avenue

Fairbanks, AK 99709-3643

(907) 451-2360

Southcentral Regional Office

555 Cordova St.

Anchorage, AK 9950

(907) 269-7500

Permit Information (907) 269-7500

$$
\text { (collect calls accepted) }
$$

Nome District Office

P.O. Box 1815

Nome, AK 99762-1815

(907) 443-2600

(907) 443-5961(fax)

Southeastern Regional Office

410 Willoughby Ave., Ste. 105

Juneau, AK 99801-1795

(907) 465-5350

Permit Information (907) 465-5342 (collect calls accepted)

DEPARTMENT OF FISH AND GAME

1255 W. 8 th St.

P.O. Box 25526 (mailing)

Juneau, AK 99802-5526

(907) $465-4100$

Habitat and Restoration Division (907) $465-4105$

Function: Protects habitat in fish-bearing fresh waters and manages refuges, sanctuaries, and critical habitats. Requires permits for any work involving: the blockage of fish passage; equipment crossings or operation in fresh waters used by anadromous fish; use, diversion, or pollution of streams containing anadromous fish; construction, exploration, or development work in state game refuges, game sanctuaries, and critical habitat areas.

Northern Regional Office Habitat and Restoration Division 1300 College Rd.

Fairbanks, AK 99701-1599

(907) 459-7289
Southcentral Regional Office

Habitat and Restoration Division

333 Raspberry Rd.

Anchorage, AK 99518-1599

(907) 267-2285

Southeastern Regional Office Habitat and Restoration Division 802 3rd St., 2nd Floor

P.O. Box 240020 (mailing)

Douglas, AK 99824-0020

(907) 465-4290

\section{OFFICE OF MANAGEMENT} AND BUDGET

Division of Governmental Coordination 240 Main St., Suite 500

P.O. Box 110030 (mailing)

Juneau, AK 99811-0030

(907) 465-3562

\begin{abstract}
Function: Conducts coordinated state review of permits for mining projects within Alaska's Coastal Management Zone. Provides information to applicants on project design for consistency with the policies and standards of the Alaska Coastal Management Program. Coordinates state response to direct federal actions, including proposed regulations, that affect Alaska's mining industry.
\end{abstract}

Southcentral Regional Office 3601 C St., Ste. 370, Frontier Bldg. Anchorage, AK 99503-5930

(907) 561-6131

(907) 561-6134 (fax)

Southeastern Regional Office 240 Main St., Suite 500 P.O. Box 110030 (mailing) Juneau, AK 99811-0030 (907) 465-3562

\section{DEPARTMENT OF NATURAL}

\section{RESOURCES}

400 Willoughby Ave., 5th Fl.

Juneau, AK 99801-1724

(907) $465-2400$

Division of Forestry

3601 C St., Ste. 1034, Frontier Bldg.

Anchorage, AK 99503-5937

(907) 762-2501

Function: Establishes guidelines to manage mining in state forests.

Northern Regional Office

3700 Airport Way

Fairbanks, AK 99709-4699

(907) $451-2660$ 
Southcentral Regional Office

3601 C St., Ste. 1008, Frontier Bldg.

Anchorage, AK 99503-5937

(907) 762-2117

Southeastern Regional Office

400 Willoughby Ave., 3rd Fl.

Juneau, AK 99801-1724

(907) $465-2491$

Division of Geological \&

Geophysical Surveys

794 University Ave., Ste. 200

Fairbanks, AK 99709-3645

(907) 451-5000

Function: Conducts geological and geophysical surveys to determine the potential of Alaska land for production of metals, minerals, fuels, and geothermal resources; locations and supplies of construction materials; potential geologic hazards to buildings, roads, bridges, and other installations and structures; and other surveys and investigations as will advance knowledge of the geology of Alaska and general geologic inventories. Publishes a variety of reports that contain the results of these investigations. Advises the public and government agencies on geologic issues. Maintains a library of geologic bulletins, reports, and periodicals. Maintains a drill-core storage facility at Eagle River.

Geologic Materials Center

P.O. Box 772805

Eagle river, AK 99577-2805

(907) 696-0079

Division of Land

3601 C St., Ste. 1122, Frontier Bldg.

Anchorage, AK 99503-5947

(907) $762-2692$

Function: Manages surface estate and resources, including materials (gravel, sand, and rock). Handles statewide and regional land-use planning. Issues leases, material-sale contracts, mill-site permits, land-use permits, and easements for temporary use of State land and access roads.

Northern Regional Office 3700 Airport Way

Fairbanks, AK 99709-4699

(907) 451-2700

Southcentral Regional Office

3601 C St., Ste. 1080, Frontier Bldg.

Anchorage, AK 99503-5937

(907) 762-2253

Southeastern Regional Office 400 Willoughby Ave. 4th Floor

Juneau, AK 99801-1724

(907) $465-3400$
Division of Mining \&

Water Management

3601 C St., Ste. 822, Frontier Bldg.

P.O. Box 107016

Anchorage, AK 99510-7016

(907) $762-2163$

\section{A. Mining}

Function: Principal agency for management of mining and reclamation on state land in Alaska. Maintains a mining information office in Fairbanks. Issues property rights to leasable minerals; adjudicates locatable mineral filings. Issues permits for hard-rock and placer-mining activity. Maintains records of mineral locations, permits, and leases. Provides technical, legal, and land-status information. Administers the Alaska Surface Mining Control and Reclamation Act (ASMACRA), which includes permitting and inspection of coal mining activity and reclamation of abandoned mines.

\section{B. Water Management}

Function: Manages water resources of the state; issues water-appropriation permits and certificates; responsible for safety of all dams in Alaska; conducts surveys to determine the locations, quantity, and quality of ground and surface water.

Northern Regional Office 3700 Airport Way Fairbanks, AK 99709-4699 (907) 451-2790 (Mining) (907) 451-2772 (Water)

Southeastern Regional Office 400 Willoughby, 4th Floor Juneau, AK 99801

(907) $465-3400$

\section{Division of Parks and Outdoor} Recreation

3601 C St., Ste. 1200, Frontier Bldg. Anchorage, AK 99503-5921

(907) $762-2600$

Function: Manages approximately $3,000,000$ acres of state park lands primarily for recreational uses, preservation of scenic values, and watershed. Responsible for overseeing mining access, recreational mining activity, and valid mining-claim holdings within state park lands.

Northern Regional Office

3700 Airport Way

Fairbanks, AK 99709-4699

(907) 451-2695

Southcentral Regional Office

3601 C St., Ste., 1280, Frontier Bldg.

Anchorage, AK 99510-7001

(907) $762-2616$
Southeastern Regional Office 400 Willoughby Ave., 4th Fl. Juneau, AK 99801-1724 (907) $465-4563$

History and Archaeology Section 3601 C St., Ste. 1278, Frontier Bldg. Anchorage, AK 99503-5921 (907) $762-2626$

DEPARTMENT OF PUBLIC SAFETY 450 Whittier St.

P.O. Box 111200 (mailing)

Juneau, AK 99811-1200

(907) $465-4322$

Division of Fish and Wildlife Protection 5700 East Tudor Rd.

Anchorage, AK 99507-1225

(907) 269-5509

Function: Enforces state laws, in particular AS Title 16. Acts as enforcement arm for Alaska Department of Fish and Game. Protects Alaska's fish and wildlife resources through enforcement of laws and regulations governing use of natural resources within Alaska. These laws are in Alaska Statutes 08, 16, 46, and Alaska Administrative Code's 05, 12, and 20.

\section{DEPARTMENT OF REVENUE}

State Office Bldg.

11th Fl., Entrance A

P.O. Box 110400 (mailing)

Juneau, AK 99811-0400

(907) 465-2300

Income and Excise Audit Division

State Office BIdg.

11 th Fl., Entrance B

P.O. Box 110420 (mailing)

Juneau, AK 99811-0420

(907) $465-2320$

(907) 465-2375 (fax)

Function: Issues licenses for mining, production, and sale of minerals. Administers mining-license tax is based on net income, including royalties. New mining operationsexcept sand and gravel mining - can apply for and receive certificates of tax exemption for the first $31 / 2$ years of operation. Tax returns must be filed annually.)

\section{UNIVERSITY OF ALASKA}

Fairbanks, AK 99775-5780

College of Natural Sciences

Department of Geology \& Geophysics 408 Brooks Building

(907) 474-7565

Function: Provides undergraduate and graduate education in geology 
and geophysics and conducts basic and applied research in geologic sciences. Offers B.S., M.S., and Ph.D. program options in general geology, economic geology, petroleum geology, geophysics, and ice-snow-permafrost geophysics.

School of Mineral Engineering

Duckering Bldg., Rm. 209

(907) 474-7366

Function: Provides undergraduate and graduate education programs in geological engineering, mining engineering, mineral preparation engineering, and petroleum engineering. Through research programs conducts laboratory and field studies to promote mineral and energy development.

\section{Mineral Industry Research} Laboratory (MIRL)

O'Neill Resources Bldg., Rm. 212B (907) 474-7135

Function: Conducts applied and basic research in exploration, development, and utilization of Alaska's mineral and coal resources with emphasis on coal characterization, coal preparation. mineral beneficiation, fine gold recovery, hydrometallurgy, and environmental concerns. Publishes reports on research results and provides general information and assistance to the mineral industry.

\section{Mining Extension Program}

Duckering Bldg., Rm. 401

(907) 474-7702

Function: Offers prospecting and introductory mineral and mining courses under an open admissions policy.

Mining and Petroleum Training Service University of Alaska Anchorage

155 Smithway, Ste. 101

Soldotna, AK 99669

(907) 262-2788

Function: Provides direct training and assistance to mine operators, service and support companies and governmental agencies in mine safety and health, mining extension, vocational mine training and technical transfer. Specialized training services in hazardous materals, first aid and CPR industrial hygiene and professional safety education and consulting are available on demand.

University of Alaska Southeast

Institute of Mining Technology

P.O. Box 22434

Juneau, AK 99802-2434

(907) $463-4840$

(907) 465-6864 (fax)
Function: The IMT is designed to train students for entry-level positions in the mining industry. Students receive their training both in the classroom and at the IMT underground mine training site (the Maggie-Kathleen). Students will also receive their Mine Safety and health Administration (MSHA) certification required by Federal Law. Training sessions last six weeks.

\section{FEDERAL AGENCIES}

\section{U.S. DEPARTMENT OF THE} INTERIOR

Office of the Secretary

1689 C St., Ste. 100

Anchorage, AK 99501-5151

(907) 271-5485

Function: Coordinates the Department of the Interior's policy and stewardship with DOI bureaus for the management of over 200 million acres of public land in Alaska.

Bureau of Land Management

Alaska State Office

222 West 7th Ave., \#13

Anchorage, AK 99513-7599

907) 271-5477

Mineral Law Branch - (907) 271-3343

Public Room - (907) 271-5960

Function: Administers federal public lands (except national parks, wildlife refuges, national monuments, national forests, and military withdrawals). Issues leases for all federal leasable minerals including oil and gas, coal, phosphates, and oil shale. Arranges for sale of minerals other than leasable or salable materials, including sand, gravel, or stone. Issues right-of-way and special-use permits. Monitors mining operations to insure protection of surface resources. Maintains land-status plats and issues patents. Records federal mining claims and annual assessment affidavits.

Anchorage District Office 6881 Abbott Loop Rd. Anchorage, AK 99507-2599

(907) 267-1246

(907) 267-1267 (fax)

Arctic District Office

1150 University Ave.

Fairbanks, AK 99709-3844

(907) $474-2300$

Nome Field Office

P.O. Box 925

Nome, AK 99762

(907) 443-2177
Glennallen District Office

P.O. Box 147

Glennallen, AK 99588

(907) 822-3217

Kobuk District Office

1150 University Ave.

Fairbanks, AK 99709-3844

(907) 474-2330

Steese-White Mountain District Office 1150 University Ave.

Fairbanks, AK 99709-3844

(907) 474-2350

Kotzebue Field Office

P.O. Box 1049

Kotzebue, AK 99752

(907) 442-3430

(907) $442-2720$ (fax)

Tok Field Office

P.O. Box 309

Tok, AK 99780

(907) 883-5121

Fairbanks Support Center and Land Information Office (Public Room)

1150 University Ave.

Fairbanks, AK 99709-3844

(907) 474-2251

Function: Primary contact for information on interior and northern regions.

U.S. Bureau of Mines

Alaska Field Operations Center

3301 C. St., Ste. 525

Anchorage, AK 99503-3935

(907) 271-2455

Function: Alaska programs are designed to aid development of a viable mineral industry in Alaska with emphasis on field programs focused towards the identification of type, amount and distribution of mineral deposits in Alaska. The field information is augmented by other Bureau programs which provided information on beneficiation technologies (research); economic feasibility studies (potential supply); and economic and environmental effects of mineral development (policy analysis). Information is provided to other government agencies to aid land planning and land use decisions, and to the private sector to identify targets of opportunity for further exploration and/or development.

Juneau Branch - AFOC

P.O. Box 20550

Juneau, AK 99802-0550

(907) 364-2111 
U.S. Fish and Wildlife Service

Region 7 Office

1011 East Tudor Rd.

Anchorage, AK 99503

(907) 786-3542

Function: Administers the federal public lands in national wildlife refuges, issues special-use permits for activities on refuges, reviews permits and applications for various mining activities on all private and public lands and waters, and provides information to regulatory agencies on fish and wildlife and their habitat. Makes recommendations to regulatory agencies to mitigate adverse environmental impacts.

Ecological Services Fairbanks

10112 th Ave., Rm. 232

Box No. 19

Fairbanks, AK 99701

(907) 456-0388

U.S. Fish and Wildlife Service

Southeast Alaska Ecological Services 3000 Vintage BIvd., Suite 201

Juneau, AK 99801-7100

(907) 586-7240

Anchorage Ecological Services

605 West 4th Ave., Rm. G-62

Anchorage, AK 99501

(907) $271-2788$

\section{U.S. Geological Survey}

Geological Division

4200 University Dr.

Anchorage, AK 99508-4663

(907) 786-7403

Function: Investigates and reports on physical resources; configuration and character of land surface; composition and structure of underlying rocks; and quality, volume, and distribution of water and minerals. Conducts 1:250,000-scale geologic mapping under the auspices of the Alaska Mineral Resource Assessment Program (AMRAP).

Water Division

4230 University Dr., Suite 201

Anchorage, AK 99508

(907)786-7100

U.S. Geological Survey Earth Science Information Center

National Mapping Division

4230 University Dr., Rm. 101

Anchorage, AK 99508-4664

(907) 786-7011

Function: Publishes and distributes all available topographic maps of Alaska, digital products, and aerial photography.
National Park Service

Alaska Regional Office

2525 Gambell St.

Anchorage, AK 99503

(907) $257-2626$

Function: Administers lands within the national park system in Alaska.

Manages oil and gas operation and valid prior-right mining claims in parklands through plans of operation under Mining in Parks Act, National Park Service regulations, and other applicable federal and state laws and regulations.

\section{U.S. DEPARTMENT OF LABOR}

Mine Safety and Health Administration

1000 Bucannon Blvd., Suite 4

Boulder City, NV 89005

Juneau Field Station

Federal Building

P.O. Box 22049

Juneau, AK 99802-2049

(907) 586-7165

Function: Administers health and safety standards to protect the health and safety of metal, nonmetal and coal miners. Cooperates with the State to develop health and safety programs and develops training programs to help prevent mine accidents and occupationally caused diseases. Under agreement with the Coal Mine Safety and Health Office, the MSHA metal/nonmetal section has assumed responsibility for enforcement and training activities at coal mines in Alaska.

Mine Safety and Health Administration Coal Mine Safety and Health, District 9 P.O. Box 25367

Denver, CO 80225

(303) 231-5458

Function: Administers health and safety standards according to the Code of Federal Regulations to protect the health and safety of coal miners; requires that each operator of a coal mine comply with these standards. Cooperates with the State to develop health and safety programs and develops training programs to help prevent coal or other mine accidents and occupationally caused diseases in the industry.

\section{U.S. DEPARTMENT OF} AGRICULTURE

Forest Service

Regional Office

Federal Bldg.

P.O. Box 21628

Juneau, AK 99802-1628

(907) 586-7862
Function: Provides joint administration of general mining laws on national forest system lands with the Bureau of Land Management. Cooperates with Department of Interior agencies in the review and issuance of mineral leases. Issues permits for disposal of sand, gravel, and stone.

\section{U.S. ENVIRONMENTAI. PROTECTION AGENCY}

Region 10 Regional Office

1200 6th Ave.

Seattle, WA 98101

(206) $442-5810$

Function: Issues National Pollutant Discharge Elimination System (NPDES) permits under the Clean Water Act to regulate effluent discharges. Maintains regulatory and review authority over wetland and NEPA/EIS-related issues.

Alaska Operations Office 222 West 7 th Ave., \#19 Anchorage, AK 99513-7588 (907) 271-5083

Alaska Operations Office 410 Willoughby Ave., Ste. 100 Juneau, AK 99801 (907) 586-7619

\section{U.S. DEPARTMENT OF THE ARMY} Corps of Engineers

Regulatory Branch

Attention: CENPA-CO-R

P.O. Box 898

Anchorage, AK 99506-0898

Call: Chief of Enforcement Section

(907) 753-2712 or (800) 478-2712 (in Alaska only)

Function: Regulates work in navigable waters of United States and discharge of dredged or fill material into United States waters, including wetlands.

Examples of regulated mining activities include construction of berms, dikes, diversion pads, stockpiles, and reclamation activities.

\section{COOPERATIVE STATE-FEDERAL} AGENCIES

Alaska Public Lands Information

Center

250 Cushman St., Ste. $1 \mathrm{~A}$

Fairbanks, AK 99701

(907) 456-0527

(907) 456-0514 (fax)

(907)456-0532 (TDD for hearing impaired)

Function: Clearinghouse for general information on outdoor recreation in Alaska. Information sources include 
U.S. Forest Service, U.S. Fish and Wildlife Service, U.S. Bureau of Land Management, U.S. Geological Survey, National Park Service, Alaska Departments of Natural Resources and Fish and Game, and Alaska Division of Tourism.

\section{BOARDS AND COMMISSIONS}

Alaska Minerals Commission

P.O. Box 80148

Fairbanks, AK 99708

(907) 479-6240

Function: The Mineral Commission was created by the Alaska State Legislature in 1986 to make recommendations to the Governor and the Legislature on ways to mitigate constraints on the development of minerals in Alaska. The Commission has published annual reports since 1987.

\section{Citizens' Advisory Commission on Federal Areas \\ 3700 Airport Way \\ Fairbanks, AK 99709 \\ (907)451-2775}

Function: The Citizens' Advisory Commission on Federal Areas was established in 1981 by the Alaska Legislature to protect the rights of Alaskans to continue their traditional uses of federal lands throughout the state. This was done in response to Congressional enactment in December 1980 of the Alaska National Interest Lands Conservation Act (ANILCA), which placed millions of acres of federally owned lands into conservation system units with restrictive land-use and management requirements.

Alaska Water Resources Board

P.O. Box 107005

Anchorage, AK 99510

(907) $762-2575$

Function: The Alaska Water Resources Board serves as an advisory group to the Governor on all matters relating to use and appropriation of water in the State of Alaska. The board has been particularly supportive of water resources legislation, including amendments to the Alaska Water Use Act for reservations of water and instream uses, basin-wide water rights adjudications, and housekeeping amendments to improve water-rights adjudication. The board has taken a keen interest in the state's water quality programs and water quality standards.
Alaska Science \& Technology Foundation 4500 Diplomacy Dr., Suite 515

Anchorage, AK 99508

(907) $272-4333$

Function: The Foundation was created to make public funds available for longterm investment in economic development and technological innovation within the State and to improve the health status of its residents. Through the awarding of grants for basic and applied research, the Foundation will enhance the State's economy and help build its science and engineering capabilities.

\section{CHAMBERS OF COMMERCE}

Alaska State Chamber of Commerce

217 Second St., Suite 201

Juneau, AK 99801

(907) 586-2323

(907) 463-5515 (fax)

Function: The State Chamber of Commerce researches and formulates positions on Alaskan resource development. Recommendations for consideration are submitted to the State Chamber of Commerce board of directors.

Juneau Chamber of Commerce

124 West 5 th Ave.

Juneau, AK 99801

(907) 586-6420

Greater Fairbanks Chamber of Commerce

709 2nd Ave.

Fairbanks, AK 99701

(907) 452-1105

Anchorage Chamber of Commerce

441 West 5th Ave., Ste. 300

Anchorage, AK 99501

(907) 272-2401

\section{PUBLIC INTEREST GROUPS} AND ASSOCIATIONS

Alaska Miners Association, Inc.

Statewide Office

501 West Northern Lights Blvd., Ste. 203

Anchorage, AK 99503-2565

(907) 276-0347

(907) 278-7997 (fax)

Anchorage Branch

501 West Northern Lights Blyd., Ste. 203

Anchorage, AK 99503-2565

(907) 276-0347

Fairbanks Branch of AMA

P.O. Box 73069

Fairbanks, AK 99707

(907) 451-6650
Juneau Branch of AMA

P.O. Box 21684

Juneau, AK 99802-1684

(907) 586-4704

(907) $463-5712$

Kenai Branch of AMA

P.O. Box 242

Sterling, AK 99672

(907) 262-6383

Nome Branch of AMA

P.O. Box 1974

Nome, AK 99762

(907) 443-2632

Alaska Women in Mining

Fairbanks Branch

P.O. Box 83542

Fairbanks, AK 99708

(907) $479-9750$

Juneau Branch

P.O. Box 34044

Juneau, AK 99804

(907)586-4161

Anchorage Branch

P.O. Box 240334

Anchorage, AK 99524

(907) 276-6762

Alaskans for Juneau

P.O. Box 22428

Juneau, AK 99802-2428

(907) 463-5065

American Institute of Professional Geologists

7828 Vance Dr., Ste. 103

Arvada, CO 80003

(303) 431-0831

Alaska Section

P.O. Box 92082

Anchorage, AK 99509-2082

(907) $562-3279$

Northwest Mining Association

10 North Post St., Ste. 414

Spokane, WA 99201

(509) 624-1158

Placer Miners of Alaska

P.O. Box 81110

Fairbanks, AK 99708

(907) 479-3100

Resource Development Council for Alaska, Inc.

121 W. Fireweed, Suite 250

Anchorage, AK 99503

(907) 276-0700

(907) 276-3887 (fax)

Society for Mining, Metallurgy, and Exploration Inc.

P.O. Box 625002

Littleton, CO 80162-5002

(303) $973-9550$ 
Secretary Treasurer-John Rishel

1505 Atkinson Dr.

Anchorage, AK 99504

(907) 337-0511

Southeast Alaska Conservation Council

(SEACC)

4196 th St., Ste. 328

Juneau, AK 99801

Trustees for Alaska

725 Christensen Dr., Ste. 4

Anchorage, AK 99501

\section{ORGANIZED MINING DISTRICTS}

Circle Mining District

P.O. Box 80674

Fairbanks, AK 99708

(907) 488-6058

Fairbanks Mining District

105 Dunbar

Fairbanks, AK 99701

(907) 456-7642

Forty-Mile Miners Association

P.O. Box 3885

Palmer, AK 99645

(907) 746-4404

Haines Mining District

P.O. Box 149

Haines, AK 99827

(907) 766-2228

Iditarod Mining District

John A. Miscovich

General Delivery

Flat, AK 99584

Juneau Mining District

P.O. Box 20765

Juneau, AK 99802

(907) 789-4065

Kantishna Mining District

P.O. Box 84608

Fairbanks, AK 99708

Koyukuk Mining District

P.O. Box 9142

Coldfoot, AK 99701

Livengood-Tolovana Mining District

P.O. Box 55698

North Pole, AK 99705

(907) 488-6453

Valdez Creek Mining District

P.O. Box 875534

Wasilla, AK 99687-5534
Yentna Mining District

13004 NE 9 th Ave.

Vancouver, WA 98685

MINERAL EDUCATION PROGRAMS

ALASKA MINERAL AND ENERGY RESOURCE EDUCATION FUND (AMEREF

c/o RDC

121 W. Fireweed Lane, Suite 250

Anchorage, AK 99503

(907) 276-0070

(907) 276-3887 (fax)

Function: A nonprofit corporation formed to help prepare students in grades $K-12$ to make informed decisions about Alaska's mineral and energy resources.

Alaska Department of Education 801 W. 10th St., Ste. 200

Juneau, AK 99801-1894

(907) 465-8719

NATIVE REGIONAL CORPORATIONS

\section{AHTNA INCORPORATED}

Main Office

P.O. Box 649

Glennallen, AK 99588-0649

(907) 822-3476

(907) 822-3495 (fax)

Anchorage Office

406 Fireweed Lane, Ste. 203

Anchorage, AK 99503

(907) 274-7662

(907) 274-6614 (fax)

THE ALEUT CORPORATION

4000 Old Seward Hwy, \#300

Anchorage, AK 99503-6087

(907) 56I-4300

(907) $563-4328$ (fax)

\section{ARCTIC SLOPE REGIONAL} CORPORATION

P.O. Box 129

Barrow, AK 99723-0129

(907) 852-8633

(907) 852-8533

(907) 852-5733 (fax)

Anchorage Office

301 Danner Ave., Suite 300

Anchorage, AK 99518-3035

(907) 349-2369

(907) $349-5476$ (fax)
BERING STRAITS NATIVE

CORPORATION

P.O. Box 1008

Nome, AK 99762-1008

(907) 443-5252

(907) 443-2985 (fax)

\section{BRISTOL BAY NATIVE}

CORPORATION

800 Cordova Street

P.O. Box 100220 (mailing)

Anchorage, AK 99510-0220

(907) 278-3602

(907) 276-3924 (fax)

\section{CALISTA CORPORATION}

601 W. 5 th Ave., Suite 200

Anchorage, AK 99501-2225

(907) 279-5516

(907) 272-5060 (fax)

CHUGACH ALASKA

\section{CORPORATION}

560 E. 34th Ave., Ste. 200

Anchorage, AK 99503-4196

(907) 563-8866

(907) 563-8402 (fax)

COOK INLET REGION INC.

and its subsidary North Pacific

Mining Corporation

P.O. Box 93330

Anchorage, AK 99509-3330

(907) 274-8638

(907) 279-8836 (fax)

DOYON LTD.

201 1st Ave., Suite 300

Fairbanks, AK 99701

(907) $452-4755$

(907) 456-6785 (fax)

KONIAG INCORPORATED

4300 B St., Suite 407

Anchorage, AK 99503

(907) 561-2668

(907) $562-5258$ (fax)

NANA REGIONAL CORPORATION

P.O. Box 49

Kotzebue, AK 99752

(907) 442-3301

(907) $442-2866$ (fax)

Anchorage Ofrice

1001 E. Benson Blvd.

Anchorage, AK 99508

(907) 265-4100

(907) $265-4123$ (fax)

SEALASKA CORPORATION

One Sealaska Plaza, Ste. 400

Juneau, AK 99801

(907) 586-1512

(907) 586-2304 (fax) 


\section{APPENDIX D \\ Selected significant mineral deposits and mineral districts in Alaska ${ }^{a}$}

The alphabetized list of mineral deposits and mineral districts is keyed to the list of explanatory paragraphs that follow. For example, The Lik deposit in the alphabetized list is "Lik, 1, (fig. D-1)." This says that the location of Lik is shown as number 1 in figure D-1.

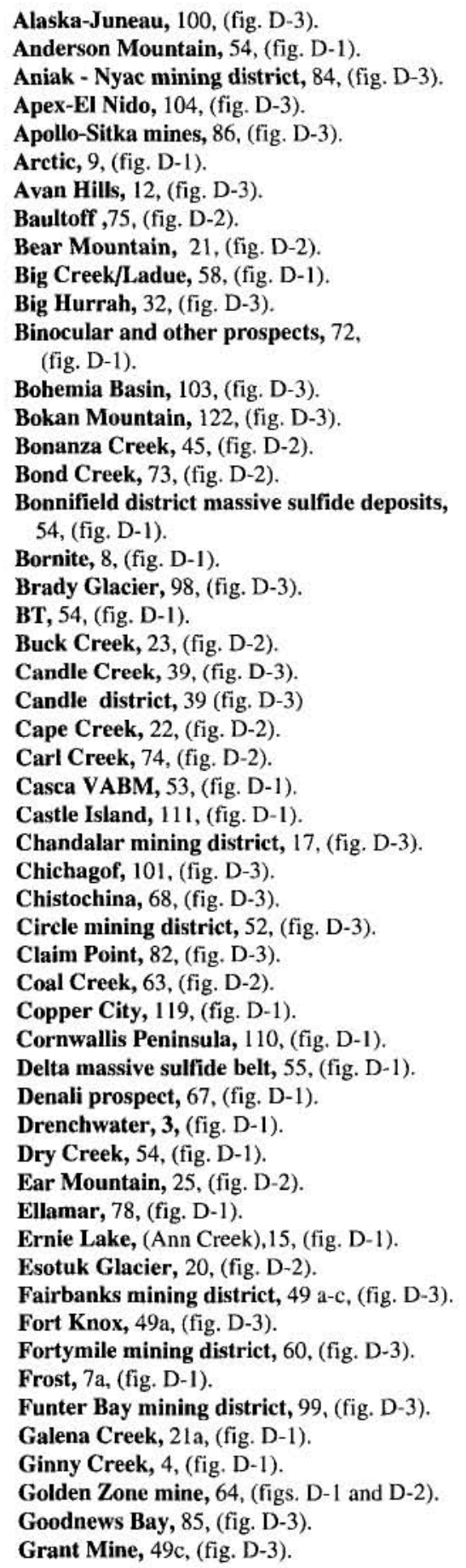

Greens Creek, 105, (fig. D-1).

Groundhog Basin, 112, (fig. D-1).

Haines Barite, 95, (fig. D-1).

Hannum, 27, (fig. D-1).

Hirst Chichagof, 101, (fig. D-3).

Horsfeld, 76, (fig. D-2).

Hot Springs mining district, 47, (fig. D-3).

Hyder mining district, 117, (figs. D-1 and D-2).

Iditarod district, 43a, (fig. D-3).

Illinois Creek, 44a, (fig. D-1).

Independence, 79, (fig. D-3).

Independence Creek, 28, (fig. D-1).

Inmachuk River, 39 (fig. D-3)

Innoko-Tolstoi mining district, $43 \mathrm{~b}$, (fig. D-3).

Ivanof, 88, (fig. D-2).

Jimmy Lake, 94, (fig. D-1).

Johnson River, 125, (fig. D-3).

Jualin, 128, (fig. D-3).

Jumbo, 118, (fig. D-1)

Kachauik, 34, (fig. D-3)

Kantishna mining district, 61, (fig. D-3).

Kasaan Peninsula, 114, (fig. D-1).

Kasna Creek, 92, (fig. D-1).

Kemuk Mountain, 123, (fig. D-3).

Kennecott deposits, 71, (fig. D-1).

Kensington, 127, (fig. D-3).

Kivliktort Mountain, 5a, (fig. D-1).

Klery Creek, 14, (fig. D-3).

Klukwan, 96, (fig. D-3).

Kougarok Mountain, 26, (fig. D-2).

Koyukuk-Hughes mining district, 42 , (fig. D-3).

Koyukuk-Nolan mining district, 16 , (fig. D-3).

Latouche, Beatson, 80, (fig. D-1).

Liberty Belle, 54, (fig. D-1).

Lik, 1, (fig. D-1).

Livengood-Tolovana mining district, 48 , (fig. D-3).

Lost River, 24, (fig. D-2).

Lucky Shot, 79, (fig. D-3)

McLeod, 124, (fig. D-2).

Mertie Lode, 99, (fig. D-3).

Midas mine, 77, (fig. D-1).

Mike deposit, 90, (fig. D-2).

Mirror Harbor, 102, (fig. D-3).

Misheguk Mountain, 13, (fig. D-3).

Mosquito, Peternie, 56, (fig. D-2).

Mt. Prindle, 50, (fig. D-3).

Nabesna mine, 69, (fig. D-3).

Niblack, 121, (fig. D-1).

Nim prospect, 65, (fig. D-1).

Nimiuktuk River, 126, (fig. D-1).
Nixon Fork, 44, (fig. D-3).

Nome mining district, 30, (fig. D-3).

Nunatak, 97, (fig. D-2).

Omalik, 35, (fig. D-1).

Omar, 7, (fig. D-1).

Orange Hill, 73, (fig. D-2).

Pebble Copper, 129, (fig. D-1).

Placer River, 38, (fig. D-2).

Pleasant Creek, 53, (fig. D-1).

Poovookpuk Mountain, 40, (fig. D-2).

Porcupine Lake, 18, (fig. D-2).

Purcell Mountain, 41, (fig. D-2).

Pyramid, 87, (fig. D-2).

Quartz Creek, 37, (fig. D-1).

Quartz Hill, 120, (fig. D-2).

Red Bluff Bay, 109, (fig. D-3).

Red Devil, 83, (fig. D-3).

Red Dog, 2, (fig. D-1).

Red Mountain, 82, (fig. D-3).

Rex deposit, 91, (fig. D-2).

Rock Creek, 31, (fig. D-3)

Rua Cove, 81, (fig. D-1).

Ruby mining district, 46, (fig. D-3).

Ryan Lode, 49b, (fig. D-3).

Salt Chuck, 115, (fig. D-3).

Sheep Creek, 54, (fig. D-1).

Sinuk River region, 29, (fig. D-1).

Slate Creek, 59, (fig. D-3).

Sleitat Mountain, 93, (fig. D-2).

Smucker, 11, (fig. D-1).

Snettisham, 107, (fig. D-3).

Snipe Bay, 113, (fig. D-3).

Solomon mining district, 33, (fig. D-3).

Spirit Mountain, 70, (fig. D-3).

Stampede mine, 62, (fig. D-3).

Story Creek, 5, (fig. D-1).

Sumdum, 106, (fig. D-1).

Sun, 10, (fig. D-1).

Taurus, 57, (fig. D-2).

Three Castle Mountain, 53, (fig. D-1).

Tracy Arm, 108, (fig. D-1).

Twin Mountain, 51, (fig. D-2).

Union Bay, 116, (fig. D-3).

Valdez Creek district, 66, (fig. D-3).

Vinasale Mountain, 44b, (fig. D-3).

Virginia Creek, 54, (fig. D-1).

Von Frank Mountain, 44c, (fig. D-3).

War Baby, 79, (fig. D-3).

Weasel Mountain, Bee Creek, 89 ,

(fig, D-2).

Whoopee Creek, 6, (fig. D-1).

Willow Creek, 79, (fig. D-3).

Wind River,19, (fig. D-1).

Windy Creek, 36, (fig. D-2).

Zackly, 67a, (fig. D-1).

${ }^{a}$ This generalized summary does not describe all of the known 6,400 mineral deposits in Alaska.

NOTE: In cooperation with DGGS and the Russian Academy of Sciences, the USGS recently released Open-File Report 93-339 (Nokleberg and others, 1993), Metallogenesis of mainland Alaska and the Russian northeast, which describes 273 lode deposits and 43 significant placer districts in Alaska. 


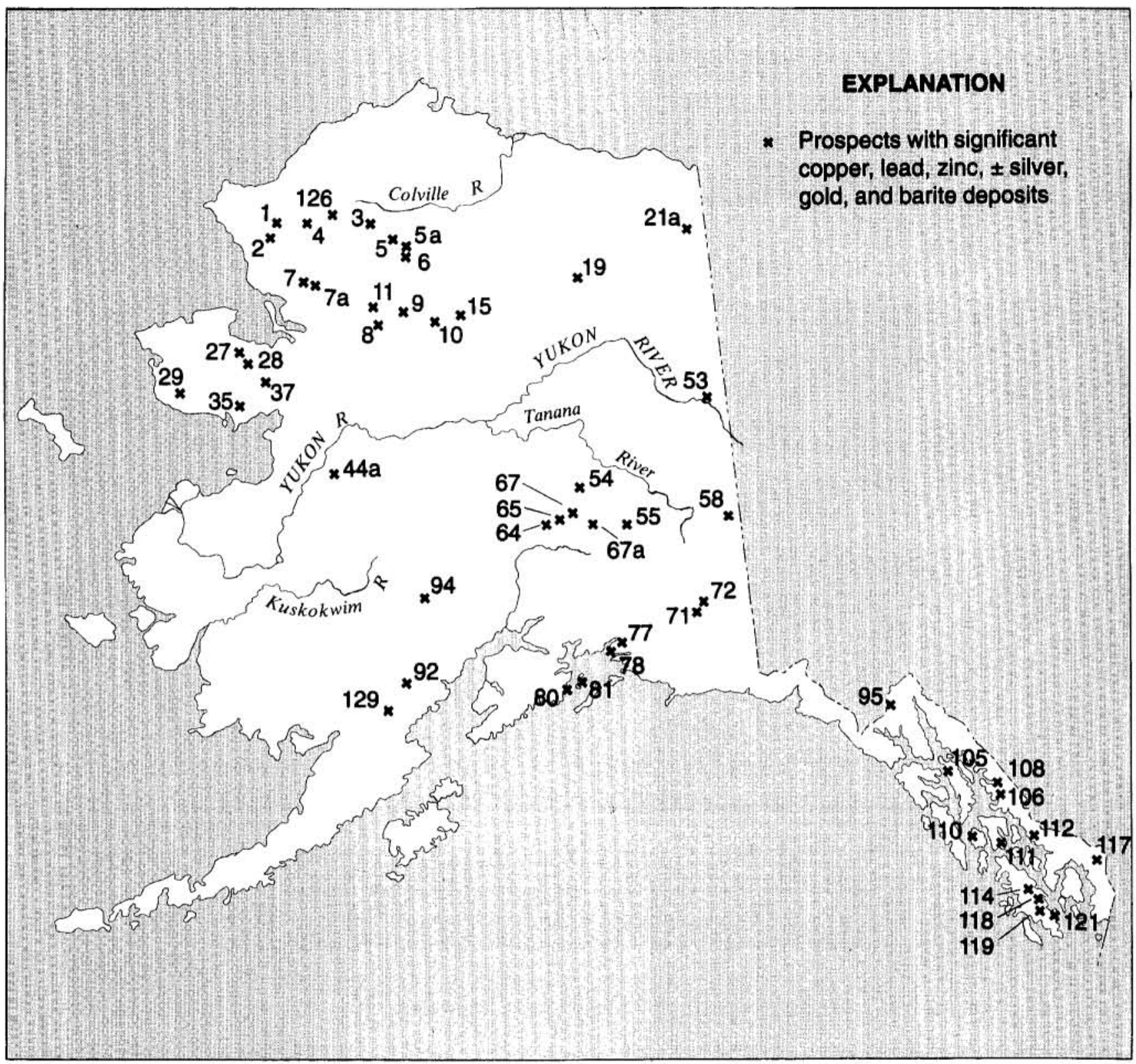

Figure D-1. Significant copper, lead, zinc with credits of silver, gold, and barite deposits in Alaska, 1994.

1 Lik - Major strata-bound massive sulfide ( $\mathrm{Zn}-\mathrm{Pb}-\mathrm{Ag}-\mathrm{Ba})$ deposit in black shale and chert. Proven reserve (Lik) estimate of 21.77 million tonnes ( 24 million tons) of $9 \% \mathrm{Zn}, 3.1 \% \mathrm{~Pb}$, and $48 \mathrm{~g} /$ tonne (1.4 oz/ton) $\mathrm{Ag}$ (fig. D-1).

2 Red Dog - At least two major strata-bound massive sulfide deposits hosted in Pennsylvanian or Mississippian shaie; similar to locality 1 . The main deposit at Red Dog contains 54.3 million tonnes ( 59.9 million tons) of measured and indicated ore grading $18.3 \% \mathrm{Zn}, 5.5 \% \mathrm{~Pb}$, with $93 \mathrm{~g} /$ tonne ( $2.71 \mathrm{oz} /$ ton) $\mathrm{Ag}$. The additional inferred reserve is 14.1 million tonnes ( 15.55 million tons) grading $10.0 \% \mathrm{Zn}, 2.7 \%$ $\mathrm{Pb}$, and $41 \mathrm{~g} /$ tonne (1.2 oz/ton) $\mathrm{Ag}$. (fig. D-1).
3 Drenchwater - Mississippian and Pennsylvanian shales and cherts contain three strata-bound base metal occurrences spatially related to acid volcanics. In the lowest unit, a siliceous mudstone, contains a $0.6 \mathrm{~m} \mathrm{(2-ft)} \mathrm{layer} \mathrm{with} \mathrm{up} \mathrm{to}$ $23 \% \mathrm{Zn}$. An overlying gray chert contains up to $11 \% \mathrm{Zn}$ and up to $5 \% \mathrm{~Pb}$ with some $\mathrm{Ag}$ in fracture fillings. At the top of the overlying tuffaceous layer, $\mathrm{Ag}$-bearing $\mathrm{Zn}$ and $\mathrm{Pb}$ mineralization outcrops discontinuously for at least $1,982 \mathrm{~m}$ $(6,500 \mathrm{ft})$, and contains up to $26 \% \mathrm{Zn}$ and $51 \% \mathrm{~Pb}$ in grab samples (fig. D-1).

4 Ginny Creek - Epigenetic, disseminated $\mathrm{Zn}-\mathrm{Pb}-\mathrm{Ag}$ deposits with barite in sandstone and shale of Noatak Sandstone of Late 


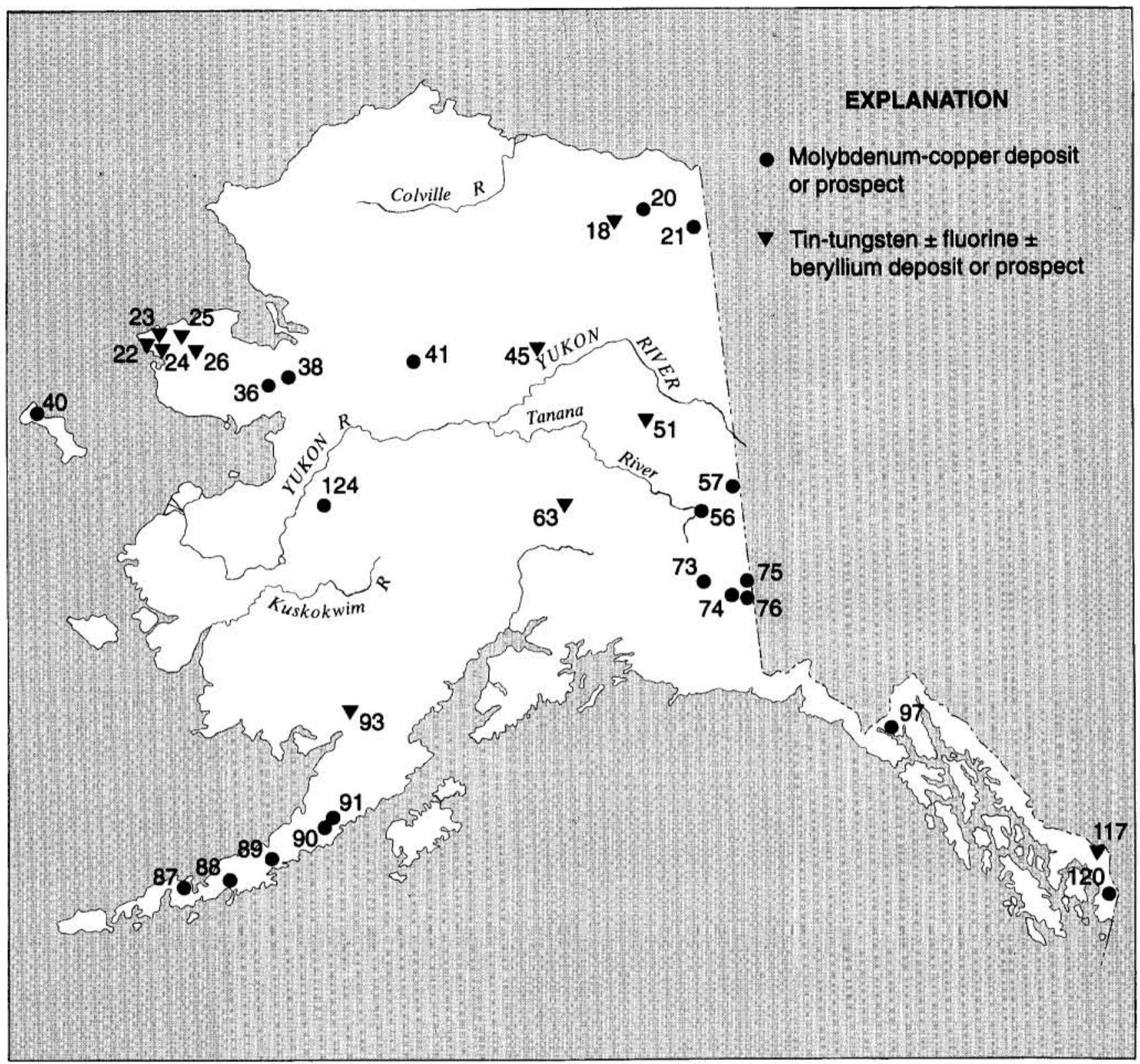

Figure D-2. Significant molybdenum-copper and tin-tungsten with credits of fluorite and beryllium deposits in Alaska, 1994.

Devonian through Early Mississippian age. Random grab samples of surface float contain $0.3 \%$ to $3.0 \% \mathrm{Zn}$ and highly variable amounts of $\mathrm{Pb}$ and $\mathrm{Ag}$ (fig. D-1).

5 Story Creek - Epigenetic replacement deposits of $\mathrm{Zn}-\mathrm{Pb}-\mathrm{Ag}$ $\mathrm{Cu}$-Au hosted in brecciated zones in Devonian Kanayut Conglomerate or Lower Mississippian Kayak Shale. Grab samples of high-grade material contain up to $0.43 \% \mathrm{Cu}, 34 \%$ $\mathrm{Pb}, 28.8 \% \mathrm{Zn}, 1.4 \mathrm{~g} /$ tonne $(0.04 \mathrm{oz} /$ ton $) \mathrm{Au}$, and $1,028 \mathrm{~g} /$ tonne (30 oz/ton) Ag (fig. D-1).

5a Kivliktort Mountain - Mineralized float is widespread on the north flanks of the mountain, apparently spatially related to the contact between shales at the base of the hills and coarsegrained siliceous clastic rocks on the upper slopes. Rock samples containing up to $30 \% \mathrm{Zn}$ have been reported (fig. D-1).
6 Whoopee Creek - Epigenetic replacement deposits of $\mathrm{Zn}-\mathrm{Pb}$ $\mathrm{Cu}-\mathrm{Ag}-\mathrm{Au}-\mathrm{Cd}$ in breccia zones in Devonian Kanayut Conglomerate or Lower Mississippian Kayak Shale. Random grab samples of mineralized material contain $0.24 \% \mathrm{Cu}, 0.37 \% \mathrm{Cd}$, $46 \% \mathrm{Zn}, 44 \% \mathrm{~Pb}, 4.8 \mathrm{~g} /$ tonne $(0.14 \mathrm{oz} /$ ton) $\mathrm{Au}$, and $507 \mathrm{~g} /$ tonne (14.8 oz/ton) Ag (fig. D-1).

7 Omar - Epigenetic replacement deposits of Paleozoic age; include bedded barite occurrences. Grab samples contain $15.3 \%$ $\mathrm{Cu}, 0.15 \% \mathrm{~Pb}, 0.95 \% \mathrm{Zn}, 0.05 \% \mathrm{Co}$, and $10 \mathrm{~g} /$ tonne $(0.3 \mathrm{oz} /$ ton) $\mathrm{Ag}$ (fig. D-1).

7a Frost - Possible 8.2 million tonnes (9 million tons) barite in pods, lenses, and wavey-banded quartz-catcite-barite veins. Chalcopyrite and galena occur in the veins which cross cut Paleozoic limestone and dolomite for a minimum distance of $1.6 \mathrm{~km}$ (1 mi). Selected samples contain up to $13.2 \% \mathrm{Zn}$ (fig. D-1). 


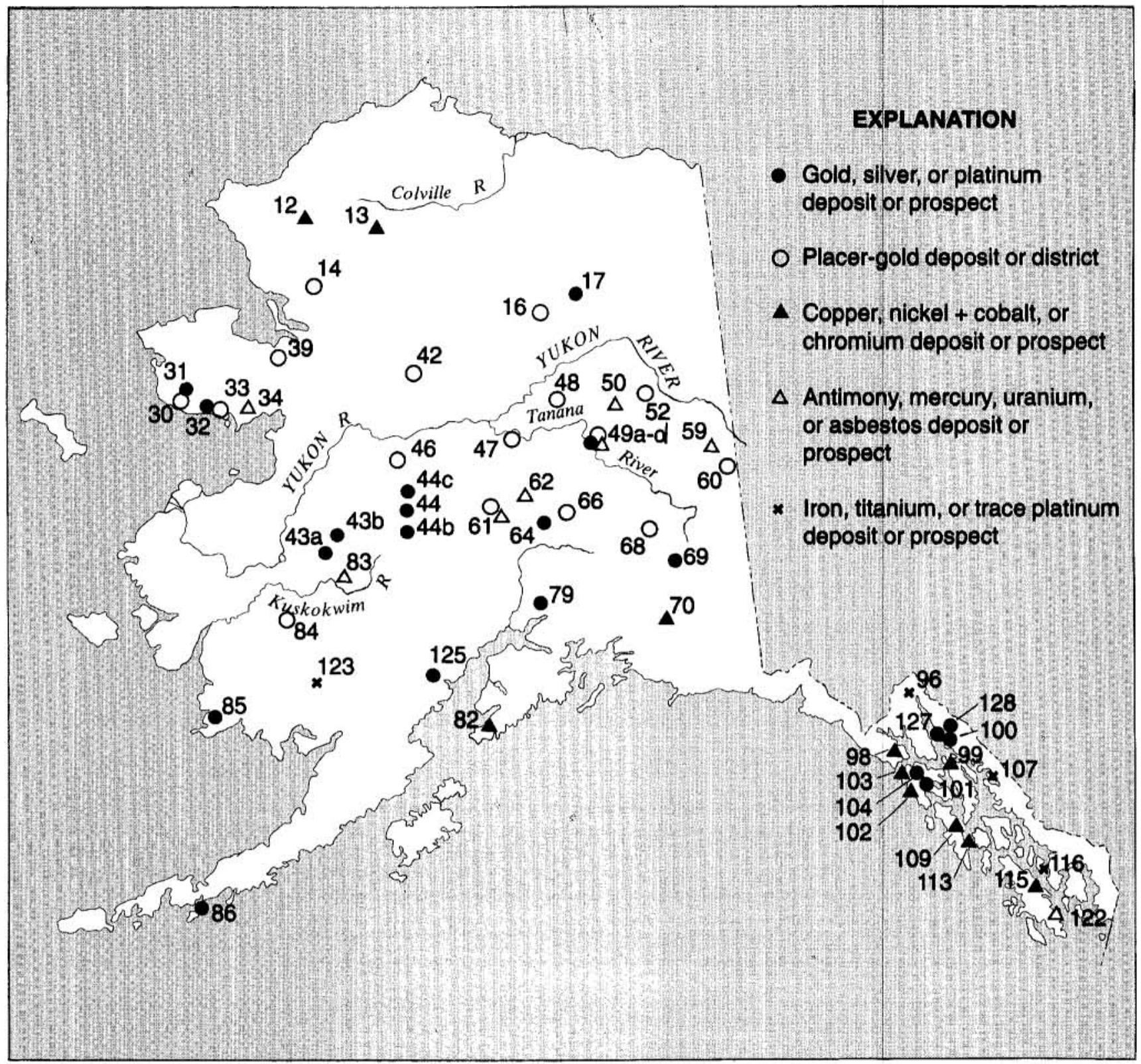

Figure D-3. Significant gold, silver, platinum, and strategic mineral deposits in Alaska, 1994.

8 Bornite - Major strata-bound $\mathrm{Cu}-\mathrm{Zn}$ deposit in brecciated carbonate rock of Devonian age; 4.56 million tonnes ( 5.0 million ton) orebody contains $4.0 \% \mathrm{Cu}$ and accessory $\mathrm{Zn}$ and $\mathrm{Co}$. Larger reserve estimate of 36.2 million tonnes ( 40 million tons) of about $2 \% \mathrm{Cu}$ and undisclosed amount of $\mathrm{Zn}$ and $\mathrm{Co}$. At grade of $1.2 \%$ $\mathrm{Cu}$, reserves are 91 million tonnes (100 million tons) (fig. D-1).

9 Arctic-Major volcanogenic $(\mathrm{Cu}-\mathrm{Zn})$ massive sulfide deposit hosted in sequence of metarhyolite, metatuff, and graphitic schist of Devonian age; indicated reserves of 36.3 million tonnes (40 million tons) grade $4.0 \% \mathrm{Cu}, 5.5 \% \mathrm{Zn}, 0.8 \% \mathrm{~Pb}, 55 \mathrm{~g} /$ tonne ( $1.6 \mathrm{oz} /$ ton) $\mathrm{Ag}$, and $0.69 \mathrm{~g} /$ tonne $(0.02 \mathrm{oz} /$ ton $) \mathrm{Au}$ (fig. D-1).

10 Sun - Major (Cu- $\mathrm{Pb}-\mathrm{Zn}-\mathrm{Ag})$ massive sulfide deposit in sequence of middle Paleozoic metarhyolite and metabasalt. Average grades are 1 to $4 \% \mathrm{~Pb}, 6$ to $12 \% \mathrm{Zn}, 0.5$ to $7 \% \mathrm{Cu}$, 103 to $377 \mathrm{~g} /$ tonne (3 to $11 \mathrm{oz} /$ ton) $\mathrm{Ag}$ (fig. D-1).
11 Smucker - Middle Paleozoic volcanogenic massive sulfide deposit; $915 \mathrm{~m}(3,000 \mathrm{ft})$ long and up to $58 \mathrm{~m}$ (190 ft) wide contains significant tonnage of $\mathrm{Cu}-\mathrm{Pb}-\mathrm{Zn}$ ore that grades $1.5 \% \mathrm{~Pb}, 5$ to $10 \% \mathrm{Zn}, 103$ to $343 \mathrm{~g} /$ tonne (3 to $10 \mathrm{oz} /$ ton) $\mathrm{Ag}$, with minor $\mathrm{Au}$ (fig. D-1).

12 Avan Hills - Disseminated chromite in layered ultramafic rocks; grab samples contain up to $4.3 \% \mathrm{Cr}$ with $0.51 \mathrm{~g}$ /tonne (0.015 oz/ton) PGM (fig. D-3).

13 Misheguk Mountain - Chromite occurrences similar to those in Avan Hills (fig. D-3).

14 Klery Creek - Lode and placer Au deposits worked intermittently from 1909 through 1930s. Total production through 1931, mostly from placer deposits, estimated at $974 \mathrm{~kg}(31,320 \mathrm{oz}) \mathrm{Au}$ (fig. D-3). 


\section{Appendix D}

15 Ernie Lake - (Ann Creek) Strata-bound massive sulfide occurrence in metarhyolite, metatuff, and marble. Gossan zones strongly anomalous in $\mathrm{Cu}-\mathrm{Pb}-\mathrm{Zn}$ and $\mathrm{Ag}$ (fig. D-1).

16 Koyukuk-Nolan mining district - Major placer Au district; from 1893 to 1993 , produced an estimated $10,101 \mathrm{~kg}$ $(324,804 \mathrm{oz}) \mathrm{Au}$. Significant deep placer reserves remain (fig. D-3).

17 Chandalar mining district - Major Au producing district; substantial production in excess of $1,964 \mathrm{~kg}(63,158 \mathrm{oz}) \mathrm{Au}$ through 1993 from lode and placer sources; lode Au found in crosscutting quartz veins that intrude schist and greenstone. Active development of placer deposits and lodes in progress. Inferred lode reserves estimated to be 40,800 tonnes (45,000 tons) with grade of $69 \mathrm{~g} /$ tonne ( $2 \mathrm{oz} /$ ton) Au (fig. D-3).

18 Porcupine Lake - Stratifor $m$ fluorite occurrences and argentiferous enargite, tetrahedrite associated with felsic volcanic rocks of late Paleozoic age. Reported grades of up to $25 \%$ to $30 \%$ fluorite $\left(\mathrm{CaF}_{2}\right)$ reported, with grab samples of $4.8 \% \mathrm{Cu}$ (fig. D-2).

19 Wind River - Strata-bound $\mathrm{Pb}-\mathrm{Zn}$ massive sulfide prospects; reported grades of up to $5 \% \mathrm{~Pb}$ (fig. D-1).

20 Esotuk Glacier - Disseminated Mo-Sn-W-Pb-Zn mineralization in skarns associated with Devonian(?) schistose quartz monzonite. Grab samples contain up to $0.08 \% \mathrm{Sn}$ and $0.15 \%$ W (fig. D-2).

21 Bear Mountain - Major stockwork Mo-W-Sn occurrence in intrusive breccia. Rock samples containing up to $0.8 \%$ Mo and $0.6 \% \mathrm{~W}$ occur within a 14 ha ( 35 acre) area where soil samples average more than $0.2 \% \mathrm{MoS}_{2}$, and an adjacent 10 ha ( 25 acre) area where rubble contains wolframite has soils averaging greater than $0.12 \% \mathrm{WO}_{3}$. Rubble crop in this area indicates a Tertiary porphyry system as the source of the Mo and W (fig. D-2).

21a Galena Creek - Steeply dipping veins contain up to $21 \% \mathrm{Cu}$, $3.5 \% \mathrm{Zn}$, and $1.3 \% \mathrm{~Pb}$ with $189 \mathrm{~g} /$ tonne $(5.5 \mathrm{oz} /$ ton $) \mathrm{Ag}$ on the east side of the creek, and a large area of disseminated mineralization and veinlets contains predominantly $\mathrm{Zn}$ on the ridge west of the creek (fig. D-1).

22 Cape Creek - Major placer Sn producer. More than 454 tonnes (500 tons) Sn produced from 1935 to 1941; from 1979 to 1990 , produced 940 tonnes ( 1,040 tons $) \mathrm{Sn}$. Derived from Cape Mountain in contact zone of Cretaceous granite and limestone (fig. D-2).

23 Buck Creek - Major placer Sn producer. More than 998 tonnes (1,100 tons) Sn produced from 1902 to 1953 (fig. D-2).

24 Lost River - Major Sn, fluorite, W, and Be deposit associated with Cretaceous $\mathrm{Sn}$ granite system. More than 317 tonnes ( 350 tons) Sn produced from skarn and greisen lode sources. Measured reserves amount to 22.3 million tonnes (24.6 million tons) that grade $0.15 \% \mathrm{Sn}, 16.3 \% \mathrm{CaF}_{2}$, and $0.03 \% \mathrm{WO}_{3}$, based on $13,720 \mathrm{~m}(45,000 \mathrm{ft})$ of diamond drilling (fig. D-2).

25 Ear Mountain - Placer $\mathrm{Sn}$ district and $\mathrm{Sn}-\mathrm{Cu}-\mathrm{Au}-\mathrm{Ag}-\mathrm{Pb}-\mathrm{Zn}$ skarn mineralization of Cretaceous age. Area also anomalous in U (fig. D-2).

26 Kougarok Mountain - $\mathrm{Sn}$ deposit hosted in quartz-tourmalinetopaz greisen of Cretaceous age. Grades may average $0.5 \% \mathrm{Sn}$
Alaska Mineral Industry 1994-Special Report 49

and $0.01 \% \mathrm{Ta}$ and $\mathrm{Nb}$, but a high grade resource of 136,050 tonnes $(150,000$ tons) grading $1 \%+\mathrm{Sn}$ has been identified, with incrementally higher tonnage at lower grades (fig. D-2).

27 Hannum - Stratiform, carbonate-hosted $\mathrm{Pb}-\mathrm{Zn}-\mathrm{Ag}$ massive sulfide deposit of mid-Paleozoic age in heavily oxidized zone that ranges from 9 to $46 \mathrm{~m}$ ( 30 to $150 \mathrm{ft}$ ) thick. Mineralized zone reported to assay up to $10 \% \mathrm{~Pb}, 2.2 \% \mathrm{Zn}, 1.4 \mathrm{~g} /$ tonne (0.04 oz/ton) Au, and $60.3 \mathrm{~g} /$ tonne (1.76 oz/ton) Ag (fig. D-1).

28 Independence Creek - $\mathrm{Pb}-\mathrm{Zn}-\mathrm{Ag}$ massive sulfide deposit; high-grade ore shipped in 1921 contained $30 \% \mathrm{~Pb}, 5 \% \mathrm{Zn}$, up to $5,141 \mathrm{~g} /$ tonne $(150 \mathrm{oz} /$ ton $) \mathrm{Ag}$. Mineralization restricted to shear zone in carbonates (fig. D-1).

29 Sinuk River region- Several $\mathrm{Pb}-\mathrm{Zn}-\mathrm{Ag}-\mathrm{Ba}-\mathrm{F}$ bearing massive sulfide deposits and layered $\mathrm{Fe}$ deposits in carbonate and metavolcanic rocks of Nome Group. Mineralized zones extend for over $2,440 \mathrm{~m}(8,000 \mathrm{ft})$ along strike (fig. D-1).

30 Nome mining district - Major placer Au producer. Production from 1897-1993 in excess of $149,982 \mathrm{~kg}(4,822,569 \mathrm{oz})$ Au all from placers. Sporadic Sb and W production in past (fig. D-3).

31 Rock Creek - About 6.6 million tons grading $2.5 \mathrm{~g} /$ tonne $(0.072 \mathrm{oz} /$ ton $) \mathrm{Au}$ in vein swarms and stringers in an area $457 \mathrm{~m}$ $(1,500 \mathrm{ft})$ long, $152 \mathrm{~m}(500 \mathrm{ft})$ maximum width and $91 \mathrm{~m}$ (300 ft) deep (fig. D-3).

32 Big Hurrah - Epigenetic vein deposit in black slate and metasedimentary rocks of the Soloman schist. Deposit contains some W mineralization and has produced over $840 \mathrm{~kg}$ (27,000 oz) Au from nearly 45,350 tonnes (50,000 tons) milled ore. Proven, inferred, and indicated reserves total 94,328 tonnes ( 104,000 tons) that grade $21 \mathrm{~g} /$ tonne ( $0.61 \mathrm{oz} /$ ton $) \mathrm{Au}, 19 \mathrm{~g} /$ tonne $(0.55 \mathrm{oz} / \mathrm{ton}) \mathrm{Ag}$, and credits of $\mathrm{WO}_{3}$ (fig. D-3).

33 Solomon mining district - Major placer Au district; produced over $12,472 \mathrm{~kg}(401,030 \mathrm{oz})$ through 1993 . Three structurally controlled Au deposits in Bluff area-Daniels Creek, Saddle, and Koyana Creek - contain minimum inferred reserves of 5.9 million tonnes ( 6.5 million tons) grading $3.4 \mathrm{~g}$ /tonne (0.1 oz/ton) Au (fig. D-3).

34 Kachauik - U prospect in Cretaceous alkalic intrusive rocks. Highly anomalous geochemical values and $\mathrm{U}$ concentrations of $1,000 \mathrm{ppm}$ reported (fig. D-3).

35 Omalik - Vein-type $\mathrm{Pb}-\mathrm{Zn}$ - $\mathrm{Ag}$ massive sulfide prospect in Paleozoic carbonate rocks; from 1881 to 1900 , produced 363 tonnes ( 400 tons) of $\mathrm{Pb}-\mathrm{Zn}$ ore that averaged about $10 \% \mathrm{~Pb}$ and $1,371 \mathrm{~g} /$ tonne $(40 \mathrm{oz} / \mathrm{ton}) \mathrm{Ag}$. Grades of oxidized $\mathrm{Zn}$ ore reported to be up to $34 \% \mathrm{Zn}$ (fig. D-1).

36 Windy Creek - Disseminated $\mathrm{Mo}-\mathrm{Pb}-\mathrm{Zn}$ mineralization in quartz veins and skarns with reported values as high as $0.15 \%$ Mo (fig. D-2).

37 Quartz Creek - Significant $\mathrm{Pb}-\mathrm{Zn}$ - $\mathrm{Ag}$ mineralization; reported grades of $15 \%$ combined $\mathrm{Pb}-\mathrm{Zn}$ and $343 \mathrm{~g} /$ tonne ( $10 \mathrm{oz} / \mathrm{ton}) \mathrm{Ag}$ (fig. D-1).

38 Placer River - Significant Mo-F mineralization disseminated in intrusive rocks. Reported values of $0.2 \%$ Mo (fig. D-2).

39 Candle/Inmachuk district - Placer deposits with $7,717 \mathrm{~kg}$ $(248,130 \mathrm{oz})$ production from 1902-1993; significant reserves 
remaining in a large ancestral channel system. Large base metal sulfide concentrations and $U$ values in concentrates (fig. D-3).

40 Poovookpuk Mountain - Porphyry Mo mineralization. Reported grades of up to $0.25 \%$ Mo (fig. D-2).

41 Purcell Mountain - Mo and Ag occurrences associated with Cretaceous alkalic igneous plutons, alaskite, and bostonite dikes (fig. D-2)

42 Koyukuk-Hughes mining district - Production of $7,084 \mathrm{~kg}$ $(227,788 \mathrm{oz})$ Au from 1930 to 1993 , mainly from Alaska Gold Company dredge at Hogatza; dredge reactivated in 1981, but deactivated in 1984, and reactivated again in 1990. Nonfloat mechanized operation on Utopia Creek produced significant amount of placer Au from 1930 to 1962 (fig. D-3).

43a Iditarod district - Major placer Au district; produced 48,492 kg $(1,559,260 \mathrm{oz})$ Au through 1993. Significant reserves of lodeAu and lode-W at Golden Horn deposit Chicken Mountain, and other known lodes in region associated with shear zones and monzonite intrusive rocks of Late Cretaceous age (fig. D-3).

43b Innoko-Tolstoi mining district - Major placer Au district with significant lode $\mathrm{Au}-\mathrm{Sb}-\mathrm{Hg}$ potential; lode sources for placers are volcanic-plutonic complexes of Late Cretaceous and dike swarms that intrude Mesozoic flysch; mining district produced 18,296 $\mathrm{kg}(588,302 \mathrm{oz})$ Au through 1993 almost all from placer deposits. New discovery on Vinasale Mountain south of McGrath is Aupolymetallic deposit in monzonite stock (fig. D-3).

44 Nixon Fork - Promising Au-Cu deposits; Nixon Fork mine produced $1,851 \mathrm{~kg}(59,500 \mathrm{oz})$ Au from Late Cretaceous skarns associated with quartz monzonite-Devonian limestone contact zones. Indicated reserve of about $10,886 \mathrm{~kg}(350,000 \mathrm{oz}) \mathrm{Au}$ in 258,500 tonnes $(285,000$ tons) of ore (fig. D-3)

44a Illinois Creek - Near-surface geologic resource is 5.76 million tonnes (6.35 million tons) at $2.4 \mathrm{~g} /$ tonne $(0.070 \mathrm{oz} / \mathrm{ton})$ gold and $51.47 \mathrm{~g} /$ tonne $(1.5 \mathrm{oz} /$ ton) silver (fig. D-1).

44b Vinasale Mountain - Intrusive hosted gold deposit. Au mineralization is associated with arsenopyrite and pyrite and within zones of phyllic and silicic alteration hosted within a $69 \mathrm{Ma}$ quartz monzonite stock. Both disseminated an veinlet mineralization exist. A geologic resource of $14,351,000$ tons with an average grade of $0.067 \mathrm{opt}$ Au was identified in 1991(fig. D-3)

44c Von Frank Mountain - Gold and very weak copper mineralization are associated with chalcopyrite, pyrite, and rare molybdenite within a zone of quartz stockwork veining hosted in a $69 \mathrm{Ma}$ quartz-diorite stock. The stock is a cupola of the larger Von Frank Pluton. Drill intercepts include thicknesses up to 429 feet with an average grade of $0.013 \mathrm{opt} \mathrm{Au}$. Higher grade intercepts include 0.035 opt Au up to $135 \mathrm{ft}$. (fig. D-3).

45 Bonanza Creek - Skarn-type W mineralization along intrusive contact; no published information available (fig. D-2).

46 Ruby mining district - Placer Au-Sn district; produced more than $14,611 \mathrm{~kg}(469,795 \mathrm{oz})$ Au from 1931 to 1993 ; mining district also contains $\mathrm{Pb}-\mathrm{Ag}$ prospects with grades reportedly as high as $2,811 \mathrm{~g} /$ tonne ( $82 \mathrm{oz} /$ ton) $\mathrm{Ag}$ (fig. D-3).

47 Hot Springs mining district - Placer Au-Sn district; produced more than $17,432 \mathrm{~kg}(560,532 \mathrm{oz}) \mathrm{Au}$ and over $326,590 \mathrm{~kg}$
(720,000 lb) cassiterite through 1993. Includes Eureka and Tofty subdistricts (fig. D-3).

48 Livengood-Tolovana mining district - Placer Au district; produced more than $14,928 \mathrm{~kg}(480,013 \mathrm{oz})$ Au since discovery in 1914 to 1993. Substantial reserves remain mainly on Livengood Bench, a Pliocene ancestral channel (fig. D-3).

49 Fairbanks mining district - Nationally ranked Au-producing district; largest producer in Alaska. Produced about $247,899 \mathrm{~kg}$ $(7,971,028 \mathrm{oz}) \mathrm{Au}$ from placer deposits. Major lode-Au and lode-Sb producer; produced more than $9,472 \mathrm{~kg}(304,548 \mathrm{oz})$ Au and over 1.8 million $\mathrm{kg}$ ( 4 million $\mathrm{lb}) \mathrm{Sb}$ from veins and shear zones through 1990. Production of W exceeded 4,000 STU since 1915, all derived from skarn near Cretaceous quartz monzonite.

49a Fort Knox - Disseminated Au deposit within granodiorite/ quartz monzonite pluton near Fairbanks. Proven and probable reserves, open at depth, are $128,000 \mathrm{~kg}(4,117,000$ oz) of gold in 158.3 million tonnes (174.5 million tons) of rock (fig. D-3).

49b Ryan lode - Based on a $0.51 \mathrm{~g} /$ tonne $(0.015 \mathrm{oz} / \mathrm{ton})$ cutoff, total reserves in the metasediment-hosted Ryan Lode and subparallel igneous-hosted Curlew Shear are $25,573 \mathrm{~kg}$ $(822,200 \mathrm{oz}$ ) of gold in 13.2 million tonnes (14.6 million tons) of rock. A geologic resource of about $74,468 \mathrm{~kg} \mathrm{(2.4} \mathrm{million}$ oz) occurs within the total shear zone system (fig, D-3).

49c Grant Mine - A series of subparallel Au-bearing quartz veins in the schist and quartzite of Ester Dome. Indicated reserves, 1990 , on one vein system, the O'Dea, are 192,285 tonnes $(212,000$ tons $)$ of $12 \mathrm{~g} /$ tonne $(0.36 \mathrm{oz} / \mathrm{ton}) \mathrm{Au}$. Other similar vein systems have been identified within the property (fig. D-3).

49d True North - Au occurs in siderite-quartz veins in carbonaceous quartzite and schist within a terrane containing eclogitic rocks. The proven and probable mineable reserve is 6.24 million tonnes ( 6.87 million tons) grading $2.23 \mathrm{~g} /$ tonne $\mathrm{Ag}(0.065 \mathrm{oz} /$ ton) for a contained $13,872 \mathrm{~kg}(446,000 \mathrm{oz}) \mathrm{Au}$. Further exploration is expected to increase the reserve base (fig. D-3).

50 Mt. Prindle - Significant U-rare-earth mineralization in Mesozoic alkaline igneous rocks. Rock geochemical values of up to $0.7 \% \mathrm{U}$; up to $15 \%$ rare-earth elements reported (fig. D-3).

51 Twin Mountain - Significant W mineralization associated with skarn development along contact zone of quartz monzonite stock of Cretaceous age (fig. D-2).

52 Circle mining district - Currently one of Alaska's largest producing placer-Au district; produced $31,717 \mathrm{~kg}(1,019,843 \mathrm{oz})$ Au since discovery in 1893 to 1993 . Has significant potential for $\mathrm{Sn}, \mathrm{W}$, and Au mineralization from variety of lode sources (fig. D-3).

53 Three Castle Mountain, Pleasant Creek, Casca VABM Strata-bound $\mathrm{Pb}-\mathrm{Zn}$ massive sulfide mineralization. Reported grades of up to $17 \% \mathrm{Zn}$ and $2 \% \mathrm{~Pb}$ (fig. D-1).

54 Bonnifield district massive sulfide deposits (Anderson Mountain, Dry Creek, Sheep Creek, Virginia Creek, BT, Liberty Belle) - Significant volcanogenic $\mathrm{Cu}-\mathrm{Pb}-\mathrm{Zn}-\mathrm{Ag}$ massive sulfide deposits of Devonian to Mississippian age in Bonnifield mining district. Potential for high-grade deposits 
reported. Includes Liberty Bell strata-bound Au-B deposit and mineralization in Sheep Creek; latter contains $\mathrm{Sn}$ as well as base metals (fig. D-1).

55 Delta massive sulfide belt - Contains at least 30 known volcanogenic massive sulfide deposits and occurrences. Grades from $0.3 \%$ to $1.1 \% \mathrm{Cu}, 1.7 \%$ to $5.7 \% \mathrm{Zn}, 0.5 \%$ to $2.3 \% \mathrm{~Pb}, 24$ to $69 \mathrm{~g} /$ tonne $(0.7$ to $2.0 \mathrm{oz} /$ ton $) \mathrm{Ag}$, and 0.61 to $2.1 \mathrm{~g} /$ tonne $(0.018$ to $0.061 \mathrm{oz} / \mathrm{ton}) \mathrm{Au}$; estimated potential reserve of 34.6 million tonnes ( 40 million tons) for all deposits (fig. D-1)

56 Mosquito, Peternie - Porphyry Mo prospects of early Tertiary age; reported grades of up to $0.17 \%$ Mo (fig. D-2).

57 Taurus - Significant major porphyry Cu-Au prospect of Paleocene age. East Taurus Zone contains inferred reserves of 126 million tonnes ( 140 million tons) grading about $0.30 \% \mathrm{Cu}$ and $.34 \mathrm{~g} /$ tonne $(0.01 \mathrm{oz} / \mathrm{ton}) \mathrm{Au}$, and $0.03 \% \mathrm{Mo}$ (fig. D-2).

58 Big Creek, Ladue - Strata-bound $\mathrm{Pb}-\mathrm{Zn}-\mathrm{Ag}$ massive sulfide prospects in metavolcanic rocks (fig. D-1).

59 Slate Creek - At least 50 million tonnes (55 million tons) of $6.3 \%$, high-quality chrysotile asbestos in serpentinized ultramafic rocks of Permian(?) age (fig. D-3).

60 Fortymile mining district - Major placer Au district. Produced over $16,491 \mathrm{~kg}(530,265 \mathrm{oz})$ placer and very minor lode $\mathrm{Au}$ since discovery in 1886 to 1993 (fig. D-3).

61 Kantishna mining district - Major placer $\mathrm{Au}$ and lode $\mathrm{Ag}$ Au-Pb-Zn-Sb-W district. Produced $3,089 \mathrm{~kg}(99,307 \mathrm{oz})$ placer and lode- $\mathrm{Au}$, about $9,549 \mathrm{~kg}(307,000 \mathrm{oz})$ lode $\mathrm{Ag}$, and 2.3 million $\mathrm{kg}$ ( 5 million $\mathrm{lb}$ ) Sb from shear zones and vein deposits hosted in metamorphic units of Yukon-Tanana terrane. Nearly 90 lode deposits have been identified; potential exists for significant $\mathrm{Ag}-\mathrm{Au}-\mathrm{Pb}-\mathrm{Zn}$ resources. Metalliferous strata-bound base metal deposits occur in schist and quartzite (fig. D-3).

62 Stampede mine - Major $\mathrm{Sb}$ deposit; produced more than 1.42 million $\mathrm{kg}$ ( 3.5 million $\mathrm{lb}$ ) Sb from large shear zone in polymetamorphic rocks of Yukon-Tanana terrane (fig. D-3).

63 Coal Creek - Greisen-hosted Sn-Cu-W deposit in "McKinley" age pluton (55 million-year-old). Reported reserves of 4.54 million tonnes ( 5 million tons) of ore that grade $0.28 \% \mathrm{Sn}$ and $0.3 \% \mathrm{Cu}$ with credits of $\mathrm{W}, \mathrm{Ag}$, and $\mathrm{Zn}$ (fig. D-2)

64 Golden Zone mine - Major Au-Cu-Ag deposits in Late Cretaceous breccia pipe. Produced more than $49 \mathrm{~kg}(1,581 \mathrm{oz})$ $\mathrm{Au}, 268 \mathrm{~kg}(8,617 \mathrm{oz}) \mathrm{Ag}$, and $19,051 \mathrm{~kg}(42,000 \mathrm{lb}) \mathrm{Cu}$. Estimated reserves are $7,153 \mathrm{~kg}(230,000 \mathrm{oz})$ of $\mathrm{Au}$ in about 1.8 million tonnes ( 2 million tons) ore (figs. D-1 and D-3).

65 Nim Prospect - Porphyry Cu-Ag-Au deposit of Late Cretaceous age. Reported grades of up to $5.0 \% \mathrm{Cu}$ and $309 \mathrm{~g} /$ tonne $(9 \mathrm{oz} / \mathrm{ton})$ Ag (fig. D-1).

66 Valdez Creek district - About $13,307 \mathrm{~kg}(427,875 \mathrm{oz}) \mathrm{Au}$ production through 1993. Cambior Alaska Inc., the largest placer mine in Alaska, operates in this district (fig. D-3).

67 Denali Prospect - At least six small, strata-bound $\mathrm{Cu}$ lodes in volcanic sedimentary rocks of Triassic age that may contain 4.54 million tonnes ( 5 million tons) ore that grade about $2 \% \mathrm{Cu}$ with credits of $\mathrm{Ag}$ (fig. D-1). 67a Zackly - Disseminated copper and gold in a garnet-pyroxene skarn and marble. Reserves are estimated as 1.27 million tonnes ( 1.4 million tons) grading 2.6 percent $\mathrm{Cu}$ and $6.0 \mathrm{~g} /$ ton (0.175 oz/ton) Au (fig. D-1).

68 Chistochina - Porphyry Cu prospects of Tertiary age and placer-Au district; produced more than 5,637 $\mathrm{kg}(181,261 \mathrm{oz})$ Au and small amount Pt from placer deposits (fig. D-3).

69 Nabesna mine - Classic high-grade Au skarn that envelopes quartz diorite of Jurassic(?) age; produced over $2,068 \mathrm{~kg}$ $(66,500 \mathrm{oz})$ Au from about 79,816 tonnes $(88,000$ tons) of ore from 1930 to 1941 (fig. D-3).

70 Spirit Mountain - Massive and disseminated $\mathrm{Cu}-\mathrm{Ni}$ mineralization in mafic-ultramafic complex (fig. D-3).

71 Kennecott deposits - Major stratifor $\mathrm{m} \mathrm{Cu}-\mathrm{Ag}$ massive sulfide deposits localized near contact between Chitistone Limestone and Nikolai Greenstone of Triassic age; contained some of highest grade $\mathrm{Cu}$ lodes mined in North America. From 1911 to 1938 , produced more than 544 million $\mathrm{kg}$ ( 1.2 billion $\mathrm{lb}$ ) $\mathrm{Cu}$ and $311,028 \mathrm{~kg}$ ( 10 million $\mathrm{oz}$ ) $\mathrm{Ag}$ from 4.35 million tonnes (4.8 million tons) ore. Some reserves remain (fig. D-1)

72 Binocular and other prospects - Kennecott-type $\mathrm{Cu}-\mathrm{Ag}$ massive sulfide deposits (fig. D-1).

73 Bond Creek - Orange Hill - Two major porphyry Cu-Mo deposits of Late Cretaceous age; reported inferred reserves of 770 million tonnes ( 850 million tons) ore that grade 0.3 to $0.5 \% \mathrm{Cu}$ and $0.03 \% \mathrm{Mo}$ (fig. D-2).

74 Carl Creek - Porphyry Cu prospect in altered intrusive complex; similar to locality 73 (fig. D-2).

75 Baultoff - Porphyry $\mathrm{Cu}$ prospect in altered intrusive rocks inferred reserves of 132 million tonnes ( 145 million tons) of $0.20 \%$ Cu similar to locality 73 (fig. D-2).

76 Horsfeld - Porphyry Cu prospect; similar to locality 73 (fig. D-2).

77 Midas mine - Significant strata-bound $\mathrm{Cu}(\mathrm{Ag}-\mathrm{Au}-\mathrm{Pb}-\mathrm{Zn})$ massive sulfide deposit in volcanic sedimentary rocks of Tertiary Orca Group. Produced more than 1.5 million kg (3.3 million lb) $\mathrm{Cu}$ from 44,760 tonnes $(49,350$ tons) ore (fig. D-1).

78 Ellamar - Strata-bound $\mathrm{Cu}-\mathrm{Zn}$-Au massive sulfide deposit in sediment of Eocene(?) Orca Group. Produced more than 7.3million $\mathrm{kg}$ ( 16 million lb) Cu, $1,596 \mathrm{~kg}(51,307 \mathrm{oz}) \mathrm{Au}$ and $5,960 \mathrm{~kg}(191,615 \mathrm{oz}) \mathrm{Ag}$ from about 273,764 tonnes (301,835 tons) ore (fig. D-1).

79 Willow Creek, Independence, Lucky Shot, War Baby Major lode- $\mathrm{Au}(\mathrm{Ag}-\mathrm{Cu}-\mathrm{Pb}-\mathrm{Zn}-\mathrm{Mo})$ in veins that cut Mesozoic quartz diorite. Produced more than $18,860 \mathrm{~kg}(606,400 \mathrm{oz}) \mathrm{Au}$ from lode sources and about $1,729 \mathrm{~kg}(55,600 \mathrm{oz}) \mathrm{Au}$ from associated placer deposits (fig. D-3).

80 Latouche, Beatson - Major strata-bound $\mathrm{Cu}-\mathrm{Zn}-\mathrm{Ag}$ massive sulfide deposits in Orca Group sedimentary rocks and mafic volcanic rocks. Produced more than 93 milion $\mathrm{kg}$ (205 million lb) $\mathrm{Cu}$ from 5.4 million tonnes (6 million tons) ore. Inferred reserves of 4.53 million tonnes ( 5 million tons) ore that grade $1 \% \mathrm{Cu}, 1.5 \% \mathrm{~Pb}+\mathrm{Zn}$ (fig. D-1). 
81 Rua Cove - Major strata-bound $\mathrm{Cu}-\mathrm{Zn}$ massive sulfide deposit in complex ore shoots enclosed in mafic volcanic rocks of Orca Group. Reported reserves of over 1 million tonnes (1.1 million tons) ore that grade $1.25 \% \mathrm{Cu}$ (fig. D-1).

82 Red Mountain and Claim Point - Significant Cr occurrence associated with layered ultramafic complexes of Tertiary age at Red Mountain near Seldovia. More than 35,419 tonnes $(39,951$ tons) metallurgical-grade ore shipped through 1976; huge low-grade $\mathrm{Cr}$ resource may remain, of which 27 million tonnes ( 30 million tons) grade $5.1 \% \mathrm{Cr}_{2} \mathrm{O}_{3}$ (fig. D-3).

83 Red Devil - Major Hg-Sb deposit; high-grade epithermal $\mathrm{Hg}$-Sb deposit hosted in shear zones in Kuskokwim Group sedimentary rocks. More than 1.24 million $\mathrm{kg}(35,000$ flasks $) \mathrm{Hg}$ produced from 68,025 tonnes ( 75,000 tons) ore (fig. D-3).

84 Aniak/Nyac mining district - Significant placer Au district. Aniak mining district produced $16,442 \mathrm{~kg}(528,670 \mathrm{oz})$ Au from placer deposits, mainly from the Nyac and Donlin Creek areas (fig. D-3).

85 Goodnews Bay - Major placer Pt district; estimated to have produced over $17,261 \mathrm{~kg}(555,000 \mathrm{oz})$ refined PGE metals from 1934 to 1976; one of the largest known PGE metal resources in United States. Possible resources of 45 million $\mathrm{m}^{3}(60$ million $\mathrm{yd}^{3}$ ) of deep, PGE-bearing gravels remain. Lode source believed to be Alaskan-type zoned ultramafic complex of Jurasssic or Cretaceous age. Possible significant offshore placer potential (fig. D-3).

86 Apollo-Sitka mines - Major lode Au deposits; produced more than $3,347 \mathrm{~kg}(107,600 \mathrm{oz})$ Au from ore that averaged about $7.5 \mathrm{~g} /$ tonne $(0.22 \mathrm{oz} /$ ton $) \mathrm{Au}$. Inferred reserves are 678,440 tonnes ( 748,000 tons) grading $26 \mathrm{~g} /$ tonne $(0.76 \mathrm{oz} /$ ton) $\mathrm{Au}, 74 \mathrm{~g} /$ tonne $(2.16 \mathrm{oz} / \mathrm{ton}) \mathrm{Ag}$, with base metal credits (fig. D-3).

87 Pyramid - Late Tertiary porphyry Cu-Mo deposit; inferred reserves of 113 million tonnes (125 million tons) ore that grade $0.4 \% \mathrm{Cu}$ and $0.03 \%$ Mo reported (fig. D-2).

88 Ivanof - Late Tertiary porphyry Cu prospect; grades of up to $0.72 \% \mathrm{Cu}$ reported. Potential for large tonnages (fig. D-2).

89 Weasel Mountain, Bee Creek - Porphyry Cu-Mo prospect of late Tertiary to Quaternary age; grades of up to $0.48 \% \mathrm{Cu}$ and $0.035 \%$ Mo reported. Potential for moderate tonnages of lowgrade mineralization (fig. D-2).

90 Mike deposit - Porphyry Mo prospect of late Tertiary age; grades of up to $0.21 \%$ Mo reported. Potential for large tonnages of low-grade Mo mineralization (fig. D-2).

91 Rex deposit - Porphyry $\mathrm{Cu}$ prospect similar to locality 90 ; grades of up to $0.3 \% \mathrm{Cu}$ reported. Potential for moderate reserves of low-grade mineralization (fig. D-2).

92 Kasna Creek - Major stratiform Cu-Pb- $\mathrm{Zn}$ and skarn-sulfide deposits of Mesozoic age in mafic, volcanic, and sedimentary rocks; reported reserves of over $9,070,000$ tonnes ( 10 million tons) ore that grade more than $1 \% \mathrm{Cu}$ (fig. D-1).

93 Sleitat Mountain - High-grade east-west-trending, Sn-W-Ag topaz-quartz greisen system hosted in 59 million-year-old old binary granite and in hornfels. Zone up to $1,915 \mathrm{~m}(3,000 \mathrm{ft})$ long and $152 \mathrm{~m}(500 \mathrm{ft})$ wide. One drill-hole showed $26 \mathrm{~m}$ $(85 \mathrm{ft})$ of $1.8 \% \mathrm{Sn}$, and $0.4 \% \mathrm{~W}$. Inferred resources are 58 to
96 million $\mathrm{kg}$ ( 128 to 212 million lb) Sn in 26.3 million tonnes (29 million tons) ore (fig. D-2).

94 Jimmy Lake - Complex Cu-Ag-Sn mineralization of late Tertiary(?) age; reported grades of up to $3,599 \mathrm{~g} /$ tonne (105 oz/ ton) $\mathrm{Ag}$ and $3 \% \mathrm{Cu}$ (fig. D-1).

95 Haines Barite - Major stratiform $\mathrm{Ba}-\mathrm{Pb}-\mathrm{Zn}-\mathrm{Cu}-\mathrm{Ag}$ deposit in pillow basalt-dominated section of Paleozoic or Triassic age; consists of 15 - to $18-\mathrm{m}$ ( 48 - to 60 -ft)-thick zone of $60 \%$ barite with upper zone [ 0.6 to $2.4 \mathrm{~m}$ ( 2 to $8 \mathrm{ft}$ ) thick] of massive sulfides that contain $2 \% \mathrm{~Pb}, 3 \% \mathrm{Zn}, 1 \% \mathrm{Cu}$, up to $137 \mathrm{~g} /$ tonne ( $4 \mathrm{oz} /$ ton) $\mathrm{Ag}$, and $4 \mathrm{~g} /$ tonne $(0.12 \mathrm{oz} /$ ton) $\mathrm{Au}$. Estimated to contain 680,250 tonnes $(750,000$ tons) of $65 \%$ barite with $\mathrm{Zn}$ and $\mathrm{Ag}$ credits (fig. D-1).

96 Klukwan - Major Fe-Ti deposits in zoned ultramafic complex of Mesozoic age; reported to contain 2.7 billion tonnes ( 3 billion tons) of material that contains $16.8 \% \mathrm{Fe}$ and 1.6 to $3.0 \% \mathrm{Ti}$ (fig. D-3).

97 Nunatak - Porphyry Mo deposit; reported reserves of 7.7 million tonnes ( 8.5 million tons) ore that grades $0.125 \% \mathrm{Mo}$ and 117 millions tonnes (129 million tons) of $0.04 \%$ Mo (fig. D-2).

98 Brady Glacier - Major Ni-Cu deposit in layered gabbropyroxenite complex of Tertiary age. Proven reserves of 91 million tonnes ( 100 million tons) ore that grade $0.5 \% \mathrm{Ni}$, $0.3 \% \mathrm{Cu}$ reported and about $0.03 \% \mathrm{Co}$; also contains PGE concentrations (fig. D-3).

99 Mertie Lode and Funter Bay mining district - Contains substantial reserves of lode Au mineralization. Past production totaled about $466 \mathrm{~kg}(15,000 \mathrm{oz}) \mathrm{Au}$. Deposits also contain significant $\mathrm{Ni}-\mathrm{Cu}$ and $\mathrm{Pb}-\mathrm{Zn}-\mathrm{Ag}$ mineralization. Funter Bay deposit contains reported reserves of 507,920 tonnes ( 560,000 tons) that grade $0.34 \% \mathrm{Ni}, 0.35 \% \mathrm{Cu}$, and $0.15 \% 0 \mathrm{Co}$ in gabbro-pipe system (fig. D-3).

100 Alaska-Juneau - Major lode Au deposit that consists of 30 to $90 \mathrm{~m}$ (100- to $300-\mathrm{ft}$ ) wide zone that contains en echelon, Au-bearing quartz veins in metamorphic rocks; produced more than $109,482 \mathrm{~kg}$ ( 3.52 million oz) Au from 80 million tonnes (88.5 million tons) ore from 1893 to 1944. Reserves (all categories), of 96 million tonnes (105.7 million tons) of $1.7 \mathrm{~g} /$ tonne ( $0.05 \mathrm{oz} /$ ton) Au remain (fig. D-3).

101 Chichagof and Hirst Chichagof - Major lode-Au deposits in quartz veins that cut Mesozoic graywacke; produced more than $23,949 \mathrm{~kg}(770,000 \mathrm{oz}) \mathrm{Au}$, most of which was produced at Chichagof mine. Inferred leased reserves estimated to be $3,110 \mathrm{~kg}(100,000 \mathrm{oz}) \mathrm{Au}$ (fig. D-2).

102 Mirror Harbor - Ni-Cu mineralization in layered-gabbro complex of Mesozoic age; reported proven reserves of 7,256 tonnes ( 8,000 tons) of $1.57 \% \mathrm{Ni}$ and $0.88 \% \mathrm{Cu}$ and reported inferred reserves of several million tons ore that grade $0.2 \% \mathrm{Ni}$ and $0.1 \% \mathrm{Cu}$ (fig. D-3).

103 Bohemia Basin - Major Ni-Cu-Co mineralization in layered mafic complex similar to locality 102 ; reported reserves of 20 million tonnes ( 22 million tons) ore that grade 0.33 to $0.51 \% \mathrm{Ni}, 0.21$ to $0.27 \% \mathrm{Cu}$, and $0.02 \% \mathrm{Co}$, all of which are recoverable with standard flotation technology (fig. D-3).

104 Apex-EI Nido - Significant lode Au-W deposits that occur as crosscutting veins in graywacke; produced more than $1,555 \mathrm{~kg}$ $(50,000 \mathrm{oz})$ Au (fig. D-3). 
105 Greens Creek - Major sediment-hosted $\mathrm{Pb}-\mathrm{Zn}-\mathrm{Cu}-\mathrm{Ag}-\mathrm{Au}$ volcanogenic massive sulfide deposit of Devonian or Triassic age; most recent reserve estimate of the original oredbody is 10 million tonnes ( 11.0 million tons) grading $4.1 \mathrm{~g} /$ tonne $(0.12$ $\mathrm{oz} /$ ton) $\mathrm{Au}, 456 \mathrm{~g} /$ tonne ( $13.3 \mathrm{oz} / \mathrm{ton}) \mathrm{Ag}, 12.8 \% \mathrm{Zn}$, and $4.0 \%$ $\mathrm{Pb}$. Additional reserves in the southwest orebody are 1.81 million tonnes (2.0 million tons) grading $13.5 \% \mathrm{Zn}, 5.5 \%$ $\mathrm{Pb}, 9.25 \mathrm{~g} /$ tonne $(0.27 \mathrm{oz} /$ ton $) \mathrm{Au}$, and $1,131 \mathrm{~g} /$ tonne $(33$ $\mathrm{oz} / \mathrm{ton}) \mathrm{Ag}$. Total combined reserves and resources of the mine are estimated to be 16.34 million tonnes ( 18 million tons) (fig. D-1).

106 Sumdum - Volcanogenic $\mathrm{Cu}-\mathrm{Pb}-\mathrm{Zn}$ massive sulfide deposit in Mesozoic metamorphic complex with potential strike length of over $3,048 \mathrm{~m}(10,000 \mathrm{ft})$. Inferred reserves of 24 million tonnes ( 26.7 million tons) ore that grade $0.57 \% \mathrm{Cu}, 0.37 \% \mathrm{Zn}$, and $10 \mathrm{~g} /$ tonne $(0.3 \mathrm{oz} /$ ton $) \mathrm{Ag}$ reported (fig. D-1).

107 Snettisham - Fe-Ti deposit in mafic zoned-intrusive complex; reported grades of about $18.9 \% \mathrm{Fe}$ and $2.6 \% \mathrm{Ti}$ (fig. D-3).

108 Tracy Arm - Strata-bound $\mathrm{Cu}-\mathrm{Zn}-\mathrm{Pb}$ massive sulfide prospect in Mesozoic schist; over $335 \mathrm{~m}(1,100 \mathrm{ft})$ long and up to $3.7 \mathrm{~m}$ $(12 \mathrm{ft})$ thick. Reported grades of $1.5 \% \mathrm{Cu}, 3.9 \% \mathrm{Zn}, 26 \mathrm{~g} /$ tonne $(0.76 \mathrm{oz} /$ ton $) \mathrm{Ag}$, and $0.44 \mathrm{~g} /$ tonne $(0.013 \mathrm{oz} / \mathrm{ton}) \mathrm{Au}$ (fig. D-1).

109 Red Bluff Bay - Significant chrome mineralization in Mesozoic ultramafic complex (probably ophiolite); reported reserves of 517 tonnes ( 570 tons) of material that grade $40 \% \mathrm{Cr}$ and 26,303 tonnes ( 29,000 tons) that grade 18 to $35 \% \mathrm{Cr}$ (fig. D-3).

110 Cornwallis Peninsula - Volcanogenic $\mathrm{Cu}-\mathrm{Pb}-\mathrm{Zn}-\mathrm{Ag}-\mathrm{Ba}$ massive sulfide deposit of Triassic(?) age; reported grades of up to $20 \% \mathrm{~Pb}-\mathrm{Zn}$ and $788 \mathrm{~g} /$ tonne ( $23 \mathrm{oz} /$ ton) $\mathrm{Ag} 9$ (fig. D-1).

111 Castle Island - Stratiform barite deposit of Triassic age hosted in carbonate and pillow basalt; about 776,390 tonnes (856,000 tons) of raw and refined barite produced from 1963 to 1980; also contains $\mathrm{Zn}, \mathrm{Pb}$, and $\mathrm{Cu}$ sulfides. Reported to be mined out (fig. D-1)

112 Groundhog Basin - Area contains several massive sulfide prospects in Mesozoic schist and gneiss whose origins are now thought to be plutonic associated. Reported grades of up to $8 \% \mathrm{~Pb}, 994 \mathrm{~g} /$ tonne $(29 \mathrm{oz} /$ ton $) \mathrm{Ag}$, and $17 \mathrm{~g} /$ tonne $(0.5 \mathrm{oz} / \mathrm{ton})$ $\mathrm{Au}$. Sn has also been recently identified. Area also contains potential for porphyry Mo deposits (fig. D-1).

113 Snipe Bay - Ni-Cu deposit in zoned mafic-ultramafic complex; inferred reserves of 390,000 tonnes ( 430,000 tons) of $0.3 \% \mathrm{Ni}$, $0.3 \% \mathrm{Cu}$, and $4.4 \mathrm{~g} /$ tonne $(0.13 \mathrm{oz} /$ ton) $\mathrm{Ag}$ reported (fig. D-3).

114 Kasaan Peninsula - Major skarn-type Cu-Fe-Au massive sulfide deposit of Jurassic age; area has produced over 12.7 million $\mathrm{kg}(28$ million lb) $\mathrm{Cu}$, and $1,711 \mathrm{~kg}(55,000 \mathrm{oz}) \mathrm{Ag}$. Reported reserves of 3.6 million tonnes ( 4 million tons) ore that grade $50 \% \mathrm{Fe}$ and less than $2 \% \mathrm{Cu}$ (fig. D-1).

115 Salt Chuck - Cu-PGM-Ag-Au deposit in contact zone between pyroxenite and gabbro within Alaskan-type zoned maficultramafic pluton. From 1900 to $1941,2.3$ million $\mathrm{kg}$ ( 5 million lb) $\mathrm{Cu}$, over $622 \mathrm{~kg}(20,000 \mathrm{oz}) \mathrm{PGM}$, and $\mathrm{Au}$ and $\mathrm{Ag}$ credits were produced from 294,775 tonnes ( 325,000 tons) ore (fig. D$3)$.

116 Union Bay - Significant Fe-Ti mineralization in ultramafic complex; area also contains $\mathrm{Pt}$ and $\mathrm{V}$ concentrations (fig. D-3).
117 Hyder mining district - Area produced more than 22,675 tonnes (25,000 tons) high-grade W-Cu-Pb- $\mathrm{Zn}-\mathrm{Ag}$ ore from 1925 to 1951 from crosscutting ore shoots in Texas Creek granodiorite of Tertiary age. Area also contains potential for porphyry Mo-W mineralization and massive sulfide-skarn $\mathrm{Pb}$ $\mathrm{Ag}-\mathrm{Au}-\mathrm{W}$ deposits (figs. D-1 and D-2).

118 Jumbo - Cu-Fe-Mo-Ag skarn deposit; produced more than 4.5 million $\mathrm{kg}$ ( 10 million $\mathrm{lb}) \mathrm{Cu}, 8,708 \mathrm{~kg}(280,000 \mathrm{oz}) \mathrm{Ag}$, and $218 \mathrm{~kg}(7,000 \mathrm{oz}) \mathrm{Au}$ from 113,375 tonnes (125,000 tons) ore. Zoned magnetite-Cu skarns are associated with epizonal granodiorite pluton of Cretaceous age. Reported reserves of 589,550 tonnes $(650,000$ tons) ore that grade $45.2 \% \mathrm{Fe}, 0.75 \%$ $\mathrm{Cu}, 0.3 \mathrm{~g} /$ tonne $(0.01 \mathrm{oz} /$ ton $) \mathrm{Au}$, and $2.74 \mathrm{~g} /$ tonne $(0.08 \mathrm{oz} /$ ton) $\mathrm{Ag}$ (fig. D-1).

119 Copper City - Stratiform Cu-Zn-Ag-Au massive sulfide deposit hosted in late Precambrian or earliest Paleozoic Wales Group. Reported grades of up to $12.7 \% \mathrm{Cu}, 2.7 \% \mathrm{Zn}, 86 \mathrm{~g} /$ tonne (2.5 oz/ton) Ag, and $6.9 \mathrm{~g} /$ tonne ( $0.2 \mathrm{oz} /$ ton) Au (fig. D-1).

120 Quartz Hill - A porphyry molybdenum deposit hosted in a 25 million-year-old composite felsic pluton. Probable reserves, according to Cominco Ltd., are 210 million tonnes ( 232 million tons) with a grade of $0.22 \% \mathrm{MoS}_{2}$, and possible reserves are 1.1 billion tonnes ( 1.2 billion tons) with $0.12 \% \mathrm{MoS}_{2}$ (fig. D-2),

121 Niblack - Volcanogenic $\mathrm{Cu}-\mathrm{Pb}-\mathrm{Au}-\mathrm{Ag}$ massive sulfide deposit hosted in Precambrian(?) Wales Group or Ordovician to Silurian Descon Formation; produced more than $635,000 \mathrm{~kg}$ (1.4 million lb) Cu, $342 \mathrm{~kg}(11,000 \mathrm{oz}) \mathrm{Au}$, and $467 \mathrm{~kg}$ (15,000 oz) Ag (fig. D-1).

122 Bokan Mountain - Numerous U-Th prospects associated with Jurassic peralkaline intrusive complex; from 1955 to 1971 , produced more than 108,840 tonnes ( 120,000 tons) ore that graded about $1 \% \mathrm{U}_{3} \mathrm{O}_{8}$. Contains inferred reserves of about 36.2 million tonnes ( 40 million tons) of $0.126 \% \mathrm{Nb}$ and up to $1 \%$ REE metals (fig. D-3).

123 Kemuk Mountain - Magmatic Fe-Ti deposit hosted in Cretaceous(?) pyroxenite. Inferred reserves of 2.17 billion tonnes ( 2.4 billion tons) that average 15 to $17 \% \mathrm{Fe}, 2$ to $3 \% \mathrm{TiO}_{2}$, and $0.16 \% \mathrm{P}_{2} \mathrm{O}_{5}$ (fig. D-3).

124 McLeod - Porphyry Mo deposit that contains quartz-molybdenite fissure veins in quartz-feldspar porphyry. Chip samples contain up to $0.09 \%$ Mo (fig. D-2).

125 Johnson River - Epigenetic(?) quartz-sulfide stockwork or massive sulfide deposit hosted in volcaniclastic, pyroclastic, and volcanic rocks of Jurassic Talkeetna Formation. Deposit has drilled out reserves at a $\$ 50 /$ tonne cutoff with no cut of high Au assays, 997,542 tonnes grading 10.35 gram $\mathrm{Au}, 7.84 \mathrm{gm} \mathrm{Ag}$, $0.76 \% \mathrm{Cu}, 1.17 \mathrm{~Pb}$, and $8.37 \% \mathrm{Zn}$ (fig. D-3).

126 Nimiuktuk River - Small hill of massive, high-grade barite estimated to contain at least 1.36 million tonnes ( 1.5 million tons) barite. Widespread stream-sediment $\mathrm{Ba}$ anomalies in area indicate further barite potential (fig. D-1).

127 Kensington - Stockworks of quartz veins in sheared and chloritized quartz diorite produced 9,886 tonnes ( 10,900 tons) grading $6 \mathrm{~g} /$ tonne $(0.18 \mathrm{oz} / \mathrm{ton})$ Au prior to 1930 . Recent reserve estimates indicate at least 10.4 million tonnes (11.5 million tons) grading $4.9 \mathrm{~g} /$ tonne $(0.143 \mathrm{oz} /$ ton $) \mathrm{Au}$. Subparallel Horrible vein system contains 3.56 million 
tonnes ( 3.93 million tons) grading $3.7 \mathrm{~g} /$ tonne (0.11 oz/ton) Au (fig. D-3).

128 Jualin - Five quartz-fissure veins in Cretaceous quartz diorite, more than $4,573 \mathrm{~m}(15,000 \mathrm{ft})$ of underground workings; produced $1,505 \mathrm{~kg}(48,387 \mathrm{oz}) \mathrm{Au}$, mainly prior to 1930 .

Reserves estimated at 0.97 million tonnes (1.07 million tons) of $12 \mathrm{~g} /$ tonne (0.349 oz/ton) Au (fig. D-3).
129 Pebble Copper - $\mathrm{Cu}$-Au porphyry with identified resource of 454 million tonnes ( 500 million tons) grading $0.35 \% \mathrm{Cu}$ and $0.4 \mathrm{~g} /$ tonne $(0.012 \mathrm{oz} /$ ton $)$ Au with $\mathrm{Mo}$ in the $0.03 \%$ to $0.04 \%$ range (fig. D- 1 ). 


\section{Appendix E}

\section{Mining licenses issued by and received from the Alaska Department of Revenue, 1994}

Entries include in this order: company name, (region), address, resource, site of operation, mining district, and license number. Alaska Peninsula Region (APR), Eastern Interior Region (EIR), Northern Region (NR), Southcentral Region (SCR), Southwestern Region (SWR), Southeastern Region (SER), Undistributed (UR), Western Region (WR), and N/A indicates specific information not provided.

\section{A \& L Mining (WR) \\ Ralph Anderson \\ P.O. Box 1974 \\ Nome, AK 99762 \\ Gold \\ Coffee Creek \\ Kougarok district \\ ML 94003581}

\section{Alamin Mining Corporation (WR) \\ 112 Park Avenue \\ Int'l Falls, MN 56649 \\ Gold \\ Bear, Cripple, and Graham \\ Creeks \\ Innoko-Tolstoi district \\ ML 94005201}

Alaska Gold Company (WR)

P.O. Box 640

Nome, AK 99762

Gold

Third Beach

Cape Nome district

ML 94002931

\section{Alaska Gold Company (WR) \\ P.O. Box 640 \\ Nome, AK 99762 \\ Gold \\ Cape Nome district \\ ML. 94003981}

Alaska Placer Development
Inc. (EIR)
P.O. Box 81467
Fairbanks, AK 99709
Gold
Livengood Creek
Tolovana-Livengood district
ML 94 00283 1
Albertson, C. Caniel \& Diann
(SCR)
P.O. Box 87
St. Anthony, ID 83445
Gold
Lake Creek
Yentna-Cache Creek district
ML 94 00545 1
Anchorage Sand and Gravel
Co. (SCR)
1040 O'Malley Rd.
Anchorage, AK 99515
Sand \& gravel
Palmer loading terminal pit
Palmer
ML 94 00246 1

$\begin{array}{ll}\text { Anderson \& Son Mining (WR) } & \text { Arctic Mining (EIR) } \\ \text { P.O. Box 277 } & \text { 373 Droz Dr. } \\ \text { McGrath, AK 99627 } & \text { Fairbanks, AK 99701 } \\ \text { Gold } & \text { Gold } \\ \text { Yankee Creek } & \text { Crooked Creek } \\ \text { Innoko-Tolstoi district } & \text { Circle district } \\ \text { ML 94 00063 1 } & \text { ML 94 00575 1 }\end{array}$

Anderson, Gerald I. (SCR)

1013 E. Dimond Blvd., \#168

Anchorage, AK 99515

Gold

Yacko Creek

Nelchina district

ML 94000371

Anderson, John/Minder
Richard (EIR)
P.O.Box 10263
Fairbanks, AK 99710
Gold
Chatanika River
Fairbanks district
ML 94005461

AOS Mining \& Engineering (EIR)

P.O. Box 72921

Fairbanks, AK 99707

Gold

Proximate Creek to Ruby Creek

Fairbanks district

ML 94005471

APP Mining (WR)

P.O. Box 1230

Nome, AK 99762

Gold

Anvil Creek

Nome district

ML 94003381

\section{APP Mining (WR)}

Bert Pettigrew

P.O. Box 1230

Nome, AK 99762

Gold

Oregon Creek

Cape Nome district

ML 94003391

Appleford, Robert J. (EIR)

1055 Commerce

Fairbanks, AK 99709

Gold

Looney Creek

Hot Springs district

ML 94005481

P.O. Box 103820

\section{AU Mining Co. (WR) \\ General Delivery \\ Candle, AK 99728 \\ Gold \\ Candle Creek-Kewalik Flats \\ Candle district \\ ML 94002401}

AU Mining Co. (WR)

Rhinehart Berg

General Delivery

Candle, AK 99728

Gold

Mud Creek

Candle district

ML 94002841

Aurora Mining (EIR)

Anchorage, AK 99510

Gold

North Fork Harrison

Circle district

ML 94001181

B\&B Mining (NR)

3910 Tilleson Way

North Pole, AK 99705

Gold

Magnet Creek

Koyukuk district

ML 94006281

Badger Mining (WR)

Peter J. Johnson

1069 Badger Rd.

North Pole, AK 99705

Gold

Beach

Cape Nome district

ML 9400622 ।

Bayless Mining (EIR)

Michael Busby

47660 Falls Creek Dr.

Homer, AK 99603

Gold

Chicken Creek

Fortymile district

ML 94001631
Beach, Curtis R. (NR)

P.O. Box 9032 Coldfoot CPU

Fairbanks, AK 99701

Gold

Sawyer Creek

Koyukuk-Nolan district

ML 94006411

Beaver Loop Sand \& Gravel (SCR)

Patrick \& Mary Doyle

HC01 Box 1225

Kenai, AK 99611

Sand \& gravel

Beaver Loop Road

Kenai district

ML 94002911

Beck, Jessie D. Jr. (EIR)

P.O. Box 10

Chicken, AK 99732

Gold

South Fork Fortymile

Fortymile district

ML 94006471

Beerman, W.J. (SCR)

2416 South 1st SE

Yakima, WA 98901

Gold

Chistochina and Copper Rivers

Chistochina district

ML 94000961

Beistline, Earl (EIR)

P.O. Box 80148

Fairbanks, AK 99708

Gold

Cripple Creek

Circle district

ML 94000891

Beistline, Earl (EIR)

P.O. Box 80148

Fairbanks, AK 99708

Gold

Mastadon Fork \& My Creek

Circle district

ML 9400094

Beistline, Earl (EIR)

P.O. Box 80148

Fairbanks, AK 99708

Gold

Eagle Creek

Circle district

ML 94004011 


\begin{tabular}{|c|c|c|c|}
\hline $\begin{array}{l}\text { Bering Straits Native Corp. } \\
\text { (WR) }\end{array}$ & $\begin{array}{l}\text { Bras, Cy T. (EIR) } \\
\text { P.O. Box } 2764\end{array}$ & Clara Bea Inc. (WR) & Congdon, Carl J. (EIR) \\
\hline P.O. Box 1808 & Kenai, AK 99611 & $\begin{array}{l}\text { P.O. Box } 1285 \\
\text { Barrow, AK } 99723\end{array}$ & $\begin{array}{l}925 \text { Commerical St. } \\
\text { Fairbanks, AK } 99701\end{array}$ \\
\hline Nome, AK 99762 & Gold & $\begin{array}{l}\text { Barrow, AK 99/23 } \\
\text { Gold }\end{array}$ & $\begin{array}{l}\text { Faurbanks, AK } 99 / 01 \\
\text { Gold }\end{array}$ \\
\hline Sand \& gravel & Canyon Creek & Candle Creek & $\begin{array}{l}\text { Gold } \\
\text { Quail Creek }\end{array}$ \\
\hline Hastings Creek & Fortymile district & Candle district & Rampart district \\
\hline Cape Nome district & ML 94002271 & ML 94001651 & ML 94005581 \\
\hline ML 9400181 I & Brittaw, Jon (EIR) & & \\
\hline Big G Mining (EIR) & P.O. Box 115 & Cleveland, C.S. (EIR) & Conway, James P. \\
\hline Hank Gradney & Hope, AK 96605 & P.O. Box 1499 & (SCR) \\
\hline P.O. Box 74400 & Gold & Bigfork, MT 59911 & $\mathrm{HC} 02 \mathrm{Box} 7160$ \\
\hline Fairbanks, AK 99707 & South Fork Fortymile & Gold & Palmer, AK 99645 \\
\hline Gold & Fortymile district & North Fork Harrison Creek & Gold \\
\hline Deadwood Creek & ML 94005541 & Circle district & Poorman Creek \\
\hline Circle district & Bruce D. Morley Inc. (SER) & ML 94002811 & Yentna-Cache Creek district \\
\hline ML 94000091 & $\begin{array}{l}9128 \text { N. Douglas } \\
\text { Juneau, AK } 99801\end{array}$ & Cleveland, C.S. (EIR) & \\
\hline Blake, Thomas Kerry (WR) & Sand \& gravel & P.O. Box 1499 & Cook's Mining (EIR) \\
\hline P.O. Box 543 & Juneau district & Bigfork, MT 59911 & P.O. Box 70456 \\
\hline Nome, AK 99762 & ML 94005551 & Gold & Fairbanks, AK 99707 \\
\hline Gold & & North Fork Harrison Creek & Gold \\
\hline Dome and Iron Creeks & Bucholz, Gary (WR) & $\begin{array}{l}\text { North Fork Harrison Creek } \\
\text { Circle district }\end{array}$ & Fairbanks Creek \\
\hline Cape Nome district & 2004 Old Steese N. & ML 94005691 & Fairbanks district \\
\hline ML 94003311 & Fairbanks, AK 99712 & & ML 94000521 \\
\hline & $\begin{array}{l}\text { Gold } \\
\text { Bear Creek }\end{array}$ & Colledge, Lyle (EIR) & \\
\hline Bluff, Ray E. (EIR) & Gold Hill-Melozitna district & $\begin{array}{l}\text { Colledge, Lyle (EIR) } \\
\text { P.O. Box } 60478\end{array}$ & Cook's Mining (EIR) \\
\hline P.O. Box 1999 & ML 94000321 & $\begin{array}{l}\text { P.O. Box } 60478 \\
\text { Fairbanks, AK } 99706\end{array}$ & P.O. Box 70456 \\
\hline Cottonwood, AZ 86326 & & $\begin{array}{l}\text { Fairbanks, AK } 99706 \\
\text { Gold }\end{array}$ & Fairbanks, AK 99707 \\
\hline Gold & Bud's Gravel Services (SCR) & $\begin{array}{l}\text { Gold } \\
\text { Bottom Dollar Creek }\end{array}$ & Gold \\
\hline Little Boulder Creek & Jason C. Johnson & $\begin{array}{l}\text { Bottom Dollar Creek } \\
\text { Circle district }\end{array}$ & Fairbanks Creek \\
\hline Hot Springs district & P.O. Box 194 & $\begin{array}{l}\text { Circle district } \\
\text { ML } 9400095 \text { I }\end{array}$ & Fairbanks district \\
\hline ML 94006391 & Anchor Point, AK 99556 & & ML 94001111 \\
\hline Bolin-Criswell Exploration & $\begin{array}{l}\text { Sand \& gravel } \\
\text { Homer }\end{array}$ & Colzani, Robert (WR) & Cook's Mining (EIR) \\
\hline $\begin{array}{l}\text { Bolin-Criswell Exploration } \\
\text { (NR) }\end{array}$ & ML 94006351 & P.O. Box 1955 & P.O. Box 70456 \\
\hline $\begin{array}{l}\text { (NR) } \\
21650 \text { Graybill St. }\end{array}$ & & Nome, AK 99762 & Fairbanks, AK 99707 \\
\hline Chugiak, AK 99567 & Cacy, Robert N./Catt, Bruce & Gold & Gold \\
\hline $\begin{array}{l}\text { Cold } \\
\text { Gouk, An } 99501\end{array}$ & (EIR) & Anvil Creek & Deep Creek \\
\hline Weise Creek & P.O. Box 45 & Cape Nome District & Fairbanks district \\
\hline Squirrel River district & Central, AK 99730 & ML 94002801 & ML 94002451 \\
\hline ML 94006461 & $\begin{array}{l}\text { Gold } \\
\text { Portage Creek }\end{array}$ & & \\
\hline & $\begin{array}{l}\text { Portage Creek } \\
\text { Circle district }\end{array}$ & Colzani, Robert (WR) & Cook Inlet Region Inc. \\
\hline $\begin{array}{l}\text { Boulder Creek Mining Co. \#2 } \\
\text { (EIR) }\end{array}$ & ML 94003431 & P.O. Box 1955 & (SCR) \\
\hline $\begin{array}{l}\text { (EIR) } \\
\text { Limited Partnership }\end{array}$ & & Nome, AK 99762 & P.O. Box 93330 \\
\hline $\begin{array}{l}\text { Limited Partnership } \\
8231 \text { Xavier Way }\end{array}$ & Carlson, Robert D. (SCR) & Gold & Anchorage, AK 99509 \\
\hline $\begin{array}{l}8231 \text { Xavier Way } \\
\text { Everett, WA } 98203\end{array}$ & P.O. Box 771375 & Benson Creek & Sand \& gravel \\
\hline & Eagle River, AK 99577 & Kougarok district & Seldovia \\
\hline $\begin{array}{l}\text { Gold } \\
\text { Boulder Creek }\end{array}$ & Gold & ML 94005281 & Homer district \\
\hline $\begin{array}{l}\text { Boulder Creek } \\
\text { Hot Springs district }\end{array}$ & Upper Cache Creek & & ML 94005591 \\
\hline $\begin{array}{l}\text { Hot Springs district } \\
\text { ML } 94001121\end{array}$ & $\begin{array}{l}\text { Yentna-Cache Creek district } \\
\text { ML } 94003331\end{array}$ & $\begin{array}{l}\text { Cominco Alaska Exploration } \\
\text { (WR) }\end{array}$ & $\begin{array}{l}\text { Cook Inlet Region Inc. } \\
\text { (SCR) }\end{array}$ \\
\hline Bouton, Glenn D. (NR) & Carroll-Vondra Inc. (EIR) & 5660 B St. & P.O. Box 93330 \\
\hline 665 Farmers Loop Rd. & Yutan Construction Co. & Anchorage, AK 99518 & Anchorage, AK 99509 \\
\hline Fairbanks, AK 99712 & P.O. Box 71775 & Gold & Sand \& gravel \\
\hline Gold & Fairbanks, AK 99707 & Pebble Copper & Seldovia \\
\hline M.F. Koyukuk & Sand \& gravel & Iliamna district & Homer district \\
\hline Koyukuk-Nolan district & $\begin{array}{l}\text { Brown's Hill } \\
\text { Fairbanks district }\end{array}$ & ML 94002291 & ML 94005601 \\
\hline ML 94000051 & $\begin{array}{l}\text { Fairbanks district } \\
\text { ML } 94002071\end{array}$ & & \\
\hline Bradley, Joe (SCR) & Central Alaska Mining (EIR) & $\begin{array}{l}\text { Cominco Alaska Exploration } \\
\text { (WR) }\end{array}$ & $\begin{array}{l}\text { Cook Inlet Region Inc. } \\
\text { (SCR) }\end{array}$ \\
\hline 1807 E. Dimond & P.O. Box 80649 & 5660 B St. & P.O. Box 93330 \\
\hline Anchorage, AK 99503 & Fairbanks, AK 99708 & Anchorage, AK 99518 & Anchorage, AK 99509 \\
\hline Gold & Gold & Gold & Sand \& gravel \\
\hline Mills Creek & Harrison Creek & Rocky Mountain Creek & Tyonek \\
\hline Yentna-Cache Creek district & Circle district & Cape Nome district & Redoubt district \\
\hline ML 94003421 & ML 94003601 & ML 94005571 & ML 94005611 \\
\hline
\end{tabular}


Cook Inlet Region Inc. (SCR)

P.O. Box 93330

Anchorage, AK 99509

Sand \& gravel

Eklutna

Anchorage district

ML 94005621

Cook Inlet Region Inc. (SCR)

P.O. Box 93330

Anchorage, AK 99509

Sand \& gravel

North Kenai

Sunrise-Seward district

ML 94005631

Cook Inlet Region Inc. (SCR)

P.O. Box 93330

Anchorage, AK 99509

Sand \& gravel

South Kenai

Homer district

ML 94005641

Cook Island Partnership (SCR)

6129 Petersburg St.

Anchorage, AK 99507

Sand \& gravel

Ind Park Sub

Anchorage district

ML 94005311

Cook, John P./Plack, Phil (SCR)

5830 Columbus Way \#6

Wasilla, AK 99654

Gold

Valdez Creek

Valdez Creek district

ML 9400539 I

Cox, Cecil A. (EIR)

P.O. Box 79

Eagle, AK 99738

Gold

Fortymile River

Fortymile district

ML 94001201

Cox, Cecil A. (EIR)

P.O. Box 79

Eagle, AK 99738

Gold

Fortymile River

Fortymile district

ML 94001211

D.J. Hopkins Company (EIR)

David Hopkins

5617 2236th Ave. NE

Redmond, WA 98053

Gold

Dome Creek

Livengood-Tolovana district

ML 94006331
Dart, James C. (EIR)

P.O. Box 18

Manley Hot Springs, AK 99756

Gold

Boulder Creek

Hot Springs district

ML 94000071

Dempsey, Dan (SCR)
P.O. Box 606
Glennallen, AK 99588
Gold
Mineral Creek
Prince William Sound distric
ML 94002391
Derrick Enterprises Inc.
$\quad$ (EIR)
P.O. Box 73574
Fairbanks, AK 99707
Gold
Crooked Creek
Circle district
ML 94003361

Derrick Enterprises Inc. (EIR)

P.O. Box 73574

Fairbanks, AK 99707

Gold

Crooked Creek

Circle district

ML 94003361

Dick, Robert D. (EIR)

6851 Chena Hot Springs Rd.

Fairbanks, AK 99712

Gold

Twelvemile Creek

Circle district

ML 94005211

Diehl, Ray (EIR)

P.O. Box 153

Yerington, NV 89447

Gold

Platt Creek

Bonnifield district

ML 9400565

Double D Mining (EIR)

Judd Edgerton

P.O. Box 3885

Palmer, AK 99645

Gold

Napoleon Creek

Fortymile district

ML 94002421

Double T Mining (EIR)

Tom Swartwood

1905 SE 140th

Portland, OR 97233

Gold

Deadwood Creek

Fairbanks district

ML 9400566
Dunshie, Jack (EIR)

4579 Woodriver Dr.

Fairbanks, AK 99701

Gold

Ruth Creek

Fairbanks district

ML 94005671

Ellis, Ed (SCR)

P.O. Box 824

Cooper Landing, AK 99572

Gold

Lake Creek

Yentna-Cache Creek district

ML 9400054

Ellis, Ed (SCR)

P.O. Box 824

Cooper Landing, AK 99572

Platinum Gr

Lake Creek

Yentna-Cache Creek district

ML 9400101

Emerson, Robert C. (EIR)

1811 Phillips Field Rd.

Fairbanks, AK 99701

Gold

St. Patrick and Happy Creeks

Fairbanks district

ML 94001731

Empire Exploration Inc. (SCR)

P.O. Box 142593

Anchorage, AK 99514

Gold

Willow Creek

Yentna-Cache Creek district

ML 9400568 I

Faa, Thomas E. (EIR)

P.O. Box 3113

Healy, AK 99743

Gold

Eva Creek

Bonnifield district

ML 94006191

Faa, Thomas E. (EIR)

HC1 Box 3113

Healy, AK 99743

Gold

Moose Creek

Bonnifield district

ML 94000511

Faa, Thomas E. (EIR)

HC1 Box 3113

Healy, AK 99743

Gold

Rex Creek

Bonnifield district

ML 94005701

Fabrizio, Jerry (SER)

4738 University Way NE

Seattle, WA 98105

Gold

Porcupine Creek

Porcupine district

ML 94000601
Fairbanks Gold Mining Inc. (EIR)

P.O. Box 73726

Fairbanks, AK 99707

Gold

Fish Creek

Fairbanks district

ML 9400361

\section{Fat Chance Mining \&}

Exploration (SCR)

Dan A. \& Jeanelle E. Loy

3921 Truro Dr.

Anchorage, AK 99507

Gold

Various Creeks

Willow Creek district

ML 94006361

Faulkner, Harry Sr. (SWR)

P.O. Box 1307

Bethel, AK 99559

Gold

Ophir Creek

Aniak district

ML. 94003011

Fejes, William C. (NR)

P.O. Box 8163

Nikiski, AK 99635

Gold

Boulder Creek

Koyukuk-Nolan district

ML 94005181

Fichtelman, Guy/Collier Don (EIR)

P.O. Box 70

Chicken, AK 99732

Gold

Fortymile River

Fortymile district

ML 94005711

Fine, Larry/Stec, Russell (SCR) P.O. Box 940316

Houston, AK 99694

Gold

East Fork Iron Creek

Valdez Creek district

ML 94006211

Flat Creek Placers (SWR)

John Fullerton

16935 Maplewild SW

Seattle, WA 98166

Gold

Willow Creek

Iditarod district

ML 9400523 I

Flat Pick Mining (EIR)

P.O. Box 115

Central, AK 99730

Gold

Switch Creek

Circle district

ML 94005721 


\author{
Four Brothers Mining \\ (EIR) \\ P.O. Box 81117 \\ Fairbanks, AK 9708 \\ Gold \\ Totatlanika River \\ Fairbanks district \\ ML 94005731 \\ Franklin, Patricia S. \\ (EIR) \\ 1213 Coppet St. \\ Fairbanks, AK 99709 \\ Gold \\ Fairbanks Creek \\ Fairbanks district \\ ML94 005741
}

G.A. Hanks \& Sons (EIR) 18908 Old River Rd. W. Sacramento, CA 95691 Gold

Lost Chicken Creek

Fortymile district

ML 9400140

Gavora, Steve (EIR)

1967 Camomile Lane

Fairbanks, AK 99712

Gold

Fairbanks Creek

Fairbanks district

ML 94003751

Geo Holding Inc. (SCR)

c/o J.W. Rayn

3101 N. Central Ave., \#1600

Phoenix, AZ 85912

Gold

Beach Uplands area

Yakataga district

ML 94005431

Gerald W. Hooper \& Assoc. (NR)

P.O. Box 875272

Wasilla, AK 99687

Gold

Swift Creek

Koyukuk-Nolan district

ML 9400307

Gibson, Wayne (WR)

1610 Southern Ave.

Fairbanks, AK 99709

Gold

Golden Creek

Gold Hill-Melozitna district

ML 9400243 I

Gibson, Wayne (EIR)

1610 Southern Ave.

Fairbanks, AK 99709

Gold

Clums Fork/Volcano Creek

Circle district

ML 94005401

\author{
Girdwood Mining Co. \\ (SCR) \\ P.O. Box 1089 \\ Girdwood, AK 99587 \\ Gold \\ Crow Creek \\ Anchorage district \\ ML 94002311
}

Glassburn, Don (EIR)

P.O. Box 107

Central, AK 99730

Gold

Gold Dust Creek

Circle district

ML 94001501

Global Resources Inc. (WR)

P.O. Box 1042

Nome, AK 99762

Gold

Cripple River

Cape Nome district

ML 94003471

Gold Hill Mining Co. (EIR)

30033 Redwood Hwy.

Cave Junction, OR 97523

Gold

Harrison Creek

Circle district

ML 94006441

Golden Slipper (EIR)

Joe B. Hall

4694 Palo Verde

Fairbanks, AK 99709

Gold

Marshall Gulch

Fairbanks district

ML 94006111

Goldorado Company (SCR)

Tod Bauer

P.O. Box 871502

Wasilla, AK 99687

Gold

Eldorado Creek

Valdez Creek district

ML 94003161

\section{Goldstream Joint Venture} (EIR)

1937 Old Steese Hwy N.

Fairbanks, AK 99712

Gold

Gilmore Creek

Fairbanks district

ML 94005761

Goldust Mines (NR)

P.O. Box 61520

Fairbanks, AK 99706

Gold

St. Mary's Creek

Chandalar district

ML 94002411
Golovin Native Corporation (WR)

P.O. Box 62099

Golovin, AK 99762

Sand \& gravel

Golovin Native Lands

Cape Nome district

ML 94003341

Goodson, Richards

(EIR)

P.O. Box 12

Chicken, AK 99732

Gold

South Fork Fortymile River

Fortymile district

ML 94005261

Grateful Dog Mining (EIR)

Roger McPherson

1100 Southwood Lane

Fairbanks, AK 99712

Gold

O'Conner Creek

Fairbanks district

ML 94001741

Grateful Dog Mining (EIR)

Roger McPherson

1100 Southwood Land

Fairbanks, AK 99712

Gold

Ridge above Treasure Creek

Fairbanks district

ML 94005821

Green Mining \& Exploration (WR)

P.O. Box 61455

Fairbanks, AK 99706

Gold

Birch Creek

Ruby-Poorman district

ML. 9400605

Groppel, Chril L. (EIR)

P.O. Box 1060

Delta Junction, AK 99737

Gold

Tenderfoot Creek

Fairbanks district

ML 94002131

Gumaer, Mark (WR)

P.O. Box 1682

Nome, AK 99762

Gold

Dick Creek

Kougarok district

ML 94003481

Gustafson, Bruce (EIR)

1787 Bobanna Lane

North Pole, AK 99705

Gold

Cody Creek

Bonnifield district

ML 9400577 I
Ham Mining Co.

(EIR)

Harold Mitchell

P.O. Box 65

Chicken, AK 99732

Gold

Misquito Fork

Fortymile district

ML 94002001

Hannah, John (EIR)

P.O. box 6117

Fairbanks, AK 99706

Gold

Flume Creek

Fairbanks district

ML 94001081

Heflinger, Fred (EIR)

P.O. Box 82390

Fairbanks, AK 99708

Gold

Walker Fork Fortymile River

Fortymile district

ML 94003911

Henshaw, Byron (SCR)

1850 Red Fox Dr.

Wasilla, AK 99654

Gold

Grogg Creek

Valdez Creek district

ML 94003851

Herndon \& Thompson

Leasing Co. (SCR)

41745 Bear Creek Dr.

Homer, AK 99603

Sand \& gravel

Parcel I, Parcel II

Homer district

ML 94002491

Herndon \& Thompson

Leasing Co. (SCR)

41745 Bear Creek Dr.

Homer, AK 99603

Sand \& gravel

Tract A

Homer district

ML 9400250

Herzog, Martin M. (SCR)

3817 South Carson St. \#428

Carson City, NV 89701

Gold

Cache Creek

Yentna-Cache Creek district ML 9400162 I

Hill, Jim (SCR)

810 E. 42nd PL \#2B

Anchorage, AK 99503

Gold

Quartz Creek

Seward district

ML 9400578 I 


Hoffman, Russell (SCR)
HC60 Box 153
Copper Center, AK 99573
Gold
Chistochina River
Chistochina district
ML 94 00276 1
Holland, Lee (EIR)
HC 33 Box 32940
Nenana, AK 99760
Gold
Above Ester Creek
Fairbanks district
ML 94001641

Hope Mining Company (SCR) P.O. Box 1010827

Anchorage, AK 99510

Gold

Resurrection Creek

Seward district

ML 94002371

Hopen, Alf (EIR)
P.O. Box 74246
Fairbanks, AK 99707
Gold
Little Eldorado Creek
Fairbanks district
ML 94001251

Hopen, Alf (EIR)

P.O. Box 74246

Fairbanks, AK 99707

Gold

Cleary Creek

Fairbanks district

ML 94005221

Hunt, Jim (NR)

P.O. Box 9061

Coldfoot, AK 99701

Gold

Slate Creek

Koyukuk-Nolan district

ML 94005342

Interior Accoutants Inc. (EIR)

Joe Vogler (Lynn Vogler)

935 Aurora Dr.

Fairbanks, AK 99709

Gold

Ketchum Creek

Circle district

ML 94005491

Ireys, Charles G. (EIR)

P.O. Box 431

Northway, AK 99764

Gold

McArthur Creek

Fortymile district

ML 94006311

J\&B Development (NR)

16655 Eagle River Rd.

Eagle River, AK 99577

Gold

Hammond River

Koyukuk-Nolan district

ML 9400255

\section{Jackson Mining Co. \\ (EIR) \\ 936 Coppet St. \\ Fairbanks, AK 99709 \\ Gold \\ Totatlanika River \\ Bonnifield district \\ ML 94003491}

Jiles, O.J. (NR)

5250 Auburn-Folsom Rd.

Loomis, CA 95650

Gold

Hammond River

Koyukuk-Nolan district

ML 9400217

\section{Jim/Mar Mining Ventures (SCR)}

James Luhrs

3333 Lakeshore Dr. \#8

Anchorage, AK 99517

Gold

Alfred Creek

Nelchina district

ML 9400538

K.L.K. Inc. (EIR)

P.O. Box 80067 D

Fairbanks, AK 99708

Gold

Faith, Hope, and Charity Creeks

Circle district

ML 9400306

Keener, Jeff (WR)

P.O. Box 82811

Fairbanks, AK 99708

Gold

Auburn and Ravine Creeks

Council district

ML 9400327

\section{Keller, Robert W.} (EIR)

P.O. Box 113

Healy, AK 99743

Gold

Totatlanika River

Bonnifield district

ML 94001921

Kelly, Timothy (EIR)

$1530 \mathrm{~W} 13$ th Ave.

Anchorage, AK 99501

Gold

North Fork Creek

Hot Springs district

ML 94003501

Kennecott-Greens Creek Mining Company (SER)

P.O. Box 32199

Juneau, AK 99803

All types

Greens Creek, Admiralty Island

Juneau

ML 9400288 ।
Kiehl, Don T. (EIR)

3210 Marneet

North Pole, AK 99705

Gold

Gold King Creek

Bonnifield district

ML 9400300

Kile, Alvin \& Eric (EIR)

P.O. Box 140424

Anchorage, AK 99514

Gold

Canyon Creek

Fortymile district

ML 94001931

Killion, M.T. (EIR)

P.O. Box 70195

Fairbanks, AK 99707

Gold

Goldstream Creek

Fairbanks district

ML 94005191

Kirsch, Bob (SCR)

P.O. Box 826

Kenai, AK 99611

Gold

Crescent Creek

Seward district

ML 94005291

Kirsch, Bob (SCR)

P.O. Box 82644

Kenai, AK 99611

Gold

Crescent Creek

Seward district

ML 94005291

Klopman, Jamin (SWR)

P.O. Box 243862

Anchorage, AK 99524

Gold

Taylor Creek

Aniak district

ML 94005131

Knutsen, Theodore (EIR)

2326 St. Elias Dr.

Anchorage, AK 99517

Gold

Birch Creek

Circle district

ML 94005501

Kralik, Jan (WR)

P.O. Box 1793

Nome, AK 99762

Gold

Gold Run

Port Clarence district

ML 94005791

Krizak, Rudy W. (WR)

P.O. Box 1253

Nome, AK 99762

Gold

Crooked Creek

Nome district

ML 94003511
Krutzsch, Betty (WR)

P.O. Box 1567

Nome, AK 99762

Gold

Speciman Gulch

Nome district

ML 94006431

Krzykowski, Ben (EIR)

P.O. Box 72544

Fairbanks, AK 99707

Gold

Big Eldorado Creek

Fairbanks district

ML 94000881

Kurt's Construction

(EIR)

Kurt A. Ueeck

HC60 Box 33560

Delta Junction, AK 99737

Gravel

Milltan Road area

Fairbanks district

ML 94001951

Lalonde, William J.

(EIR)

P.O. Box 926

Rainier, OR 97048

Gold

South Fork Fortymile River

Fortymile district

ML 94006101

Lance, Frank W. (N/A)

P.O. Box 9054

Fairbanks, AK 99701

Gold

Acme Creek

N/A

ML 94005251

Lankford, Steve (SCR)

HC 89 Box 540

Willow, AK 99688

Gold

Albert Creek

Nelchina district

ML 94001841

Las, Alan (EIR)

P.O. Box 10243

Fairbanks, AK 99710

Gold

Smith and Poole Creeks

Fairbanks district

ML 94000291

Leach, Clifford

(EIR)

P.O. Box 25

Chicken, AK 99732

Gold

South Fork Fortymile River

Fairbanks district

ML 94005801 
Leach, Clifford Jr. (EIR)

P.O. Box 25

Chicken, AK 99732

Gold

South Fork Fortymile River

Fairbanks district

ML 9400580 I

Lee, Daniel M. (EIR)

HC03 Box 8383

Palmer, AK 99645

Gold

Cherry and No Name Creeks

Fortymile district

ML 94005811

Leov, Pette H. (SWR)

P.O. Box 589

Sterling, AK 99672

Gold

Otter Creek

Iditarod district

ML 94006451

\section{Lester Mines (EIR)}

Ray Lester

732 Old Steese Hwy., \#8

Fairbanks, AK 99712

Gold

Birch Creek

Circle district

ML 94006231

Lester Mines (EIR)

Ray Lester

732 Old Steese Hwy \#8

Fairbanks, AK 99712

Gold

Butte Creek

Circle district

ML 94006241

Lillian Creek Mine Inc. (EIR)

P.O. Box 60334

Fairbanks, AK 99706

Gold

Lillian Creek

Livengood-Tolovana district

ML 94003641

Little Eldorado Gold Camp (EIR)

Andrew \& Pamela Wescott

1975 Discovery Dr.

Fairbanks, AK 99701

Gold

Fox Creek Gulch

Fairbanks district

ML 94001471

Little Eldorado Group (EIR)

W.L. Shafer

P.O. Box 80148

Fairbanks, AK 99708

Gold

Little Eldorado Creek

Fairbanks district

ML 94004031
Loud, Richard L. (EIR)

P.O. Box 10570

Fairbanks, AK 99710

Gold

Harrison Creek

Circle district

ML 94002331

Lucky Strike Mining Co. (EIR)

105 Dunbar Ave.

Fairbanks, AK 99701

Gold

Gilmore Creek

Fairbanks district

ML 94006421

Lyman Resources in Alaska

Inc. (SWR)

P.O. Box 192

McGrath, AK 99627

Gold

Snow Gulch, Crooked

Iditarod district

ML 94000821

MacDonald, Robert J. (EIR)

2829A Wronderl Way

Reno, NV 89502

Gold

Sourdough Creek

Fairbanks district

ML 94001551

MacMartin, Duncan W.

(EIR)

1305 Polar Dr.

Fairbanks, AK 99712

Gold

Pedro Creek

Fairbanks district

ML 94005831

Marchuk, Nikolas (EIR)

P.O. Box 89

Delta Junction, AK 99737

Gold

Rainy Creek

Delta River district

ML 94006201

Martinson, Douglas E. (WR)

P.O. Box 52

Nome, AK 99762

Gold

Kougarok River

Cape Nome district

ML 94006121

Martinson, Douglas E. (WR)

P.O. Box 52

Nome, AK 99762

Gold

Kougarok River

Kougarok district

ML 9400613 ।
Martinson, Douglas E. (WR)

P.O. Box 52

Nome, AK 99762

Gold

Kougarok River

Kougarok district

ML 94006141

Martinson, Douglas E. (WR)

P.O. Box 52

Nome, AK 99762

Gold

Kougarok River

Cape Nome district

ML 94006151

Mascott Mining Inc. (NR)

P.O. Box 2643

Ridgway, $\mathrm{CO} 81432$

Gold

Hammond River, Vermont Creek

Koyukuk district

ML 94001701

Mat-Su Aggregate (SCR)

Merwin L. Arneson

P.O. Box 737

Palmer, AK 99645

Sand \& gravel

Anchorage district

ML 9400356

Maxwell, Leslie or Barbara

(EIR)

P.O. Box BYA

c/o Boundary Lodge

Tok, AK 99780

Gold

Canyon Creek

Fortymile district

ML 94002141

McClanahan, Robert C. (EIR)

P.O. Box 41

Chicken, AK 99732

Gold

Bailey Creek

Fortymile district

ML 94002741

Mespelt \& Almasy Mining Co. (WR)

M.L. Mespelt \& T.J. Almasy

P.O. Box 74

McGrath, AK 99637

All types

Nixon Fork Mines

McGrath-McKinley district

ML 94006381

Metco Inc. (SCR)

HCR 64 Box 300

Seward, AK 99664

Sand \& gravel

Folz Subdivision

Seward district

ML 9400544
Miller Creek Mining Co. (EIR)

P.O. Box 2702

Fairbanks, AK 99707

Gold

Ketchum Creek

Circle district

ML 94005361

Minex Alaska Inc. (SCR)

P.O. Box 103

Girdwood, AK 99587

Gold

Beach

Kodiak-Unga Island district

ML 94000221

Misco-Walsh Mining Co. (SWR)

John Miscovich

1093 N. Greengrove St.

Orange, CA 92667

Gold

Otter Creek

Iditarod district

ML 9400084 I

Miscovich Mining Co. (WR)

Howard P. Miscovich

P.O. Box 262

Galena, AK 99741

Gold

Poorman Creek

Ruby-Poorman district

ML 9400056

Miscovich, Andrew W. (EIR)

P.O. Box 71489

Fairbanks, AK 99707

Gold

Chatham Creek

Fairbanks district

ML 94001391

Miscovich, Andrew W. (NR)

P.O. Box 71489

Fairbanks, AK 99709

Gold

Middle Fork Koyukuk River

Koyukuk district

ML 94005841

Montgomery, Melvin or Lois

(EIR)

6028 Mackay

Anchorage, AK 99518

Gold

Gilliland Creek

Fairbanks district

ML 94006401

N.B. Tweet \& Sons (WR)

P.O. Box 1107

Nome, AK 99762

Gold

Kougarok River

Kougarok district

ML 94000701 


Nevada Star Resources
(N/A)
P.O. Box 10322
Vancouver, BC V7Y 1G5
Gold
N/A
Kuskokwim River Basin
ML 94006371
Nevers, Harold A. (EIR)
8148 Pinewood Dr.
Juneau, AK 99801
Gold
American Creek
Fortymile district
ML 94002021
Nicholson, Doug/Frantz, Peter
(NR)
3865 Ullrbahn
Fairbanks, AK 99708
Gold
Linda Creek
Koyukuk district
ML 94005851

Niesen, Randy/Smith, Blair

P.O. Box 520155

Big Lake, AK 99652

Gold

Falls Creek

Yentna-Cache Creek district

ML 9400220

\section{Northern Lights Mining Inc.} (NR)

544 North 600 West

Cedar City, UT 84720

Gold

Jay, Rye, and Flat Creeks

Koyukuk district

ML 94003201

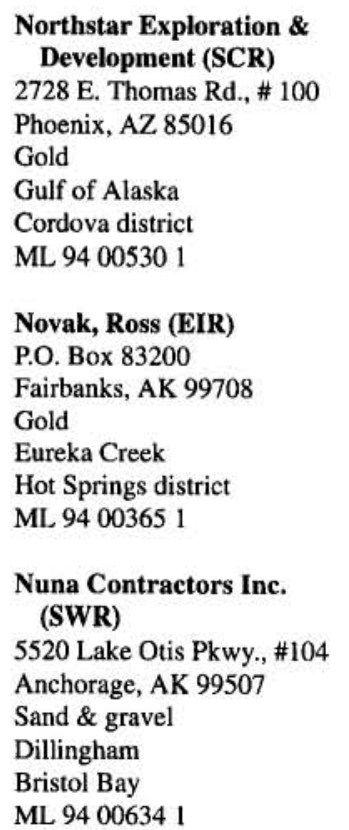

O'Daniel, J.B. (SCR)

P.O. Box 279

Springer, OK 73458

Gold

Valdez Creek

Valdez Creek district

ML 94005861

O'Daniel, J.B. (NR)

176 Sunny Hills Dr.

Fairbanks, AK 99712

Gold

Prospect Creek

Koyukuk district

ML 94005871

O'Donnell, Franklin L. Jr. (EIR)

P.O. Box 32

Chicken, AK 99732

Gold

Moose Creek

Fortymile district

ML 94002691

OI Yeller Mine (EIR)

Ralph Simonson

72382 Palmer Jct. Rd.

Elgin, OR 97827

Gold

Totatlanika River

Bonnifield district

ML 94002241

Oliver, Jim (SCR)

2208 Eureka \#9

Anchorage, AK 99503

Gold

Big Creek

Yentna-Cache Creek district ML 94002321

Olsen, Steven (EIR)

P.O. Box 58443

Fairbanks, AK 99711

Gold

Eagle Creek

Circle district

ML 94001481

Olson, Alan (WR)

P.O. Box 165

Paimer, AK 99645

Gold

Near Candle Creek

Candle district

ML 94002731

Omega Mining Company (EIR)

P.O. Box 2748

Fairbanks, AK 99707

Gold

Omega Creek

Hot Springs district

ML 94003841

\section{Outsider Mining Co. (SCR) \\ John J. Trautner \\ P.O. Box 909 \\ Girdwood, AK 99587 \\ Gold \\ Canyon Creek \\ Seward district \\ ML 94003321}

Owen, Ted (EIR)

P.O. Box BYA

c/o Robert Wolff

Tok, AK 99780

Gold

Walker Fork

Fortymile district

ML 94002571

P\&E Mining Inc. (EIR)

\#2 Hubb Rd.

P.O. Box 108

Manley Hot Springs, AK 99756

Gold

Warwick Gulch

Livengood-Tolovana district

ML 94005411

P\&E Mining Inc. (EIR)

P.O. Box 108

Manley Hot Springs, AK 99756

Gold

Gertrude Creek

Livengood-Tolovana district

ML 94005881

Pacific Mining Inc. (EIR)

P.O. Box 110842

Anchorage, AK 99511

Gold

Porcupine Creek

Circle district

ML 94003351

Parry, James (EIR)

P.O. Box 71656

Fairbanks, AK 99707

Gold

No Grub Creek

Fairbanks district

ML 94001521

Parsons, Anthony C. (WR)

P.O. Box 1496

Nome, AK 99762

Gold

Iron Creek

Kougarok district

ML 94002281

Patrick, Mike (EIR)

P.O. Box 67

Eagle, AK 99738

Gold

Fortymile River

Fortymile district

ML 94005891
Paul \& Company

(EIR)

P.O. Box 83102

Fairbanks, AK 99708

Gold

Porcupine Creek

Circle district

ML 94000411

Paul \& Company

(EIR)

P.O. Box 83102

Fairbanks, AK 99708

Gold

Crooked Creek

Circle district

ML 94006271

Paul \& Company

(EIR)

P.O. Box 83102

Fairbanks, AK 99708

Gold

Frying Pan Creek

Circle district

ML 94005901

Peterson, Donald E. (EIR)

P.O. Box 172

Haines, AK 99827

Gold

Porcupine Creek

Juneau district

ML 94005911

Philpott, Roy (NR)

P.O.Box 72198

Fairbanks, AK 99707

Gold

Smith Creek

Koyukuk district

ML 94001101

Pike, Gary R. (NR)

300 Simpson Way Box 7-13

Fox, AK 99712

Gold

Prospect Creek

Koyukuk-Nolan district

ML 94003371

Plano, Dan and/or Cindy (SWR)

P.O. Box 878275

Wasilla, AK 99687

Gold

Anvil Creek/Innoko River

Innoko district

ML 9400298

Polar Mining Inc. (EIR)

Dan May

4545 Woodriver Dr.

Fairbanks, AK 99709

Gold

Goldstream Creek

Fairbanks district

ML 94000971 


\author{
Polar Mining Inc. (EIR) \\ 4545 Woodriver Dr. \\ Fairbanks, AK 99709 \\ Gold \\ Fish Creek \\ Fairbanks district \\ ML 94005921
}

Pomrenke, Steve G. (WR)

P.O. Box 308

Nome, AK 99762

Gold

Triple Creek

Nome district

ML 9400297

Pretty Creek Mining Inc. (SCR)

P.O. Box 256

Portage, ME 04768

Gold

N/A

Redoubt district

ML 9400542

\section{Prince Creek Mining Co.} (SWR)

P.O. Box 279

Palmer, AK 99645

Gold

Prince Creek

Iditarod district

ML 94003291

Quartz Creek Exploration Co. (SCR)

Milo Flothe

P.O. Box 242

Sterling, AK 99672

Gold

Quartz Creek

Hope district

ML 94001851

R\&D Environmental Mining (EIR)

7418 Fireoak Dr

Austin, TX 78759

Gold

Hope Creek

Circle district

ML 9400198

R.A. Hanson Co. Inc. (SWR)

P.O. Box 7400

Spokane, WA 99207

Gold

Salmon River \& Tribs

Goodnews district

ML 94001241

R.A. Hanson Co. Inc. (SWR)

P.O. Box 7400

Spokane, WA 99207

Gold

Salmon River \& Tribs

Goodnews district

ML 94001231

\author{
Rainbow Mining \& \\ Development Inc. (SCR) \\ P.O. Box 697 \\ Palmer, AK 99645 \\ Gold \\ Peters Creek \\ Yentna-Cache Creek district \\ ML. 94003961
}

Red Samm Construction Inc. (SER)

P.O. Box 3097

Bellevue, WA 98009

Sand \& gravel

Lena Point

Juneau district

ML 9400188

Redmond, Richard (WR)

P.O. Box 8700

Indian, AK 99540

Gold

Macklin Creek

Kougarok district

ML 9400387

Regner, Leo A. (EIR)

P.O. Box 72733

Fairbanks, AK 99707

Gold

Lillywig Creek

Fortymile district

ML 94000901

Regner, Leo A. (EIR)

P.O. Box 72733

Fairbanks, AK 99707

Gold

Ingle Creek

Fortymile district

ML 94006061

Rhodes, James R. (SCR)

P.O. Box 2838

Kenai, AK 99611

Gold

Mills Creek

Seward district

ML 94005081

Roberts, Roger L. (SWR)

P.O. Box 7

Ophir-Takotna, AK 99675

Gold

Ophir Creek

Innoko-Tolstoi district

ML 94001051

Rubel, John (EIR)

8183 Richardson Hwy

Salcha, AK 99714

Gold

Banner Creek

Fairbanks district

ML 94002251
Salter, Ed (EIR)

P.O. Box 30

Manley, AK 99756

Gold

Pioneer Creek

Hot Springs district

ML 9400629

Sayer, Paul (SWR)

P.O. Box 20

Homer, AK 99603

Gold

Little Creek

Innoko district

ML 9400167

Schene, Earl L. (EIR)

P.O. Box 66

Chicken, AK 99732

Gold

South Fork Fortymile River

Fortymile district

ML 9400149

Schnabel, John J. (SER)

P.O. Box 149

Haines, AK 99827

Gold

Porcupine

Juneau district

ML 94000341

Scofield, Walter P. (EIR)

P.O. Box 1178

Sandy, OR 97055

Gold

South Fork Fortymile River

Fortymile district

ML 94005171

Secon Inc. (SER)

P.O. Box 3097

Bellevue, WA 98009

Sand \& gravel

Lena Point

Juneau district

ML 94005931

Seuffert, George Jr. (EIR)

P.O. Box 156

Central, AK 99730

Gold

Deadwood Creek

Circle district

ML 94001261

Shepard, M. Dennis (EIR)

P.O. Box 82504

Fairbanks, AK 99708

Gold

Chatanika River

Fairbanks district

ML 94003681

Shilling, John A. (EIR)

P.O. Box 81424

Fairbanks, AK 99708

Gold

Thanksgiving Creek

Hot Springs District

ML 94000991
Shorti-Jack Mining (EIR)

P.O. Box 71587

Fairbanks, AK 99707

Gold

Bonanza Creek

Circle district

ML 9400594

Silverado Mines (U.S.) Inc. (NR)

2580-1066 W. Hasting St.

Vancouver, BC V6E 3X2

Gold

Nolan Creek

Koyukuk-Nolan district

ML 94001531

Silverado Mines (U.S.) Inc. (EIR)

2580-1066 West Hastings

Vancouver, BC V6E 3X2

Gold

Ester Dome Uplands

Fairbanks district

ML 94005371

Simpson, Fishell \& Biddle (EIR)

2130 Nottingham Dr.

Fairbanks, AK 99709

Gold

Eureka Creek

Hot Springs district

ML 94000319

Sipes, John (EIR)

2741 Perimeter Dr.

North Pole, AK 99705

Gold

Deadwood Creek

Circle district

ML 94000451

Skidmore, Samuel C. (EIR)

P.O. Box 70470

Fairbanks, AK 99707

Gold

Vault Creek

Fairbanks district

ML 94002231

Smith, Carl R. and Beth A.

(EIR)

P.O. Box 764

Tok, AK 99780

Gold

Eagle Creek

Fortymile district

ML 94005161

Smith, Patrick D. (SCR)

P.O. Box 865

Kenai, AK 99611

Gold

N/A

Seward district

ML 9400595 
Smith, William L. (SCR)

906 Cunningham

Anchorage, AK 99501

Gold

Silvertip Creek

Seward district

ML 9400182

Snyder, Donald L.

(EIR)

P.O. Box 54

Chicken, AK 99732

Gold

South Fork Fortymile River

Fortymile district

ML 94003781

Sobanja, Hans (NR)

P.O. Box 10196

Fairbanks, AK 99710

Gold

Gold Creek

Koyukuk-Nolan district

ML 94003261

Soule, Harold L. (SCR)

2840 E. 142nd Ave.

Anchorage, AK 99516

Gold

Windy Creek

Yentna-Cache Creek district ML 94001041

Sound Quarry Inc. (WR)

P.O. Box 2011

Nome, AK 99762

Sand \& gravel

Cape Nome

Cape Nome district

ML 94001801

Sphinx Natural Resources (EIR)

Malvy Technology Inc.

9600 Long Point, Ste. 101

Houston, TX 77055

Gold

Trail Creek

Ruby district

ML 94005961

States, Mike \& Bendall, Larry (NR)

P.O. Box 81485

Fairbanks, AK 99708

Gold

Fay Creek

Koyukuk district

ML 94005971

Stebbins Native Corporation (WR)

P.O. Box 710110

Stebbins, AK 99671

Sand \& gravel

Port Clarence district

ML 9400210
Steward, Jackie J. (EIR)

P.O. Box 2607

Fairbanks, AK 99709

Gold

North Fork Goodpaster River

Fairbanks district

ML 94006071

Swan, James W. (NR)

452 Winter Ave.

Fairbanks, AK 99712

Gold

Gold Creek

Koyukuk-Nolan district

ML 94000691

Swenson, Lloyd D. (NR)

1843 Bridgewater Dr.

Fairbanks, AK 99709

Gold

Slate Creek

Koyukuk-Nolan district

ML. 94005981

Swenson, Mark D. (NR)

3424 Moosewalk Rd.

North Pole, AK 99705

Gold

Gold Creek

Koyukuk-Nolan district

ML 94005991

Swenson, Richard A.

(EIR)

P.O. Box 16205

Two Rivers, AK 99716

Gold

Doric Creek

Hot Springs district

ML 94003691

Tachick, Wayne (EIR)

P.O. Box 3503

Soldotna, AK 99669

Gold

Rex Creek

Bonnifield district

ML 94005351

Tachik, Wayne H. (EIR)

P.O. Box 3503

Soldotna, AK 99669

Gold

Eva Creek

Bonnifield district

ML 9400618 I

Taiga Mining Company Inc. (WR)

4740 E 115 th Ave.

Anchorage, AK 99516

Gold

Bear Creek

Koyukuk-Hughes district

ML 9400119 1
Taiga Mining Company Inc. (WR)

4740 E 115 th Ave.

Anchorage, AK 99516

Gold

Aloha Creek

Koyukuk-Hughes district

ML 94001351

Taiga Mining Company Inc. (WR)

4740 E 115th Ave.

Anchorage, AK 99516

Gold

Bear Creek

Koyukuk-Hughes district

ML 94006001

Taiga Mining Company Inc. (WR)

$4740 \mathrm{E} 115$ th Ave.

Anchorage, AK 99516

Gold

Clear Creek

Koyukuk-Hughes district

ML 94001361

Taylor, Larry R. (EIR)

P.O. Box 101

Eagle River, AK 99738

Gold

Fortymile River

Fortymile district

ML 94006321

Thomas, Martha (NR)

P.O. Box 10996

Fairbanks, AK 99710

Gold

Prospect

Koyukuk-Nolan district

ML 94003401

Thomas, Scott (EIR)

P.O. Box 71645

Fairbanks, AK 99707

Gold

Deadwood Creek

Circle district

ML 94003821

Three G Mining (SCR)

Jack LaCross

P.O. Box 648

Talkeetna, AK 99676

Gold

Mills Creek

Yentna-Cache Creek district

ML 94001961

\section{Thurman Oil \& Mining} (EIR)

925 Aurora Dr.

Fairbanks, AK 99709

Gold

Thanksgiving Creek

Hot Springs district

ML 9400616
Thurman Oil \& Mining (EIR)

925 Aurora Dr.

Fairbanks, AK 99709

Gold

Woodchopper Creek

Hot Springs district

ML 94006171

Thurman Oil \& Mining Inc. (EIR)

925 Aurora Dr.

Fairbanks, AK 99709

Gold

Upper Glenn Creek

Hot Springs district

ML 94000861

Thurman Oil \& Mining Inc. (EIR)

925 Aurora Dr.

Fairbanks, AK 99709

Gold

Rhode Island Creek

Manley Hot Springs district

ML 94005271

Thurneau, Neil (EIR)

P.O. Box 50

Chicken, AK 99732

Gold

Walker Fork Younger Creek

Fortymile district

ML 94003551

Toohey, Camden \& Cynthia (SCR)

P.O. Box 113

Girdwood, AK 99587

Gold

Crow Creek

Seward district

ML 94002301

Trans Alas-can Gold (SCR)

3605 Arctic Blvd., \#1382

Anchorage, AK 99503

Gold

White Creek

Valdez Creek district

ML 9400020

Trinity Mining (WR)

P.O. Box 372

Kotzebue, AK 99752

Gold

Humboldt Creek

Fairhaven-Inmachuk district ML 94000131

Trinity Mining (WR)

P.O. Box 372

Kotzebue, AK 99752

Gold

Washington Creek

Fairhaven-Inmachuk district ML 94001421 
Triple D Mining (EIR)

Daniel D. Draper

P.O. Box 213

Gakona, AK 99586

Gold

Cherry Creek

Fortymile district

ML 94005241

\section{Tuluksak Dredging}

(SWR)

NYAC Mining

$415 \mathrm{~W} 8$ th Ave.

Anchorage, AK 99501

Gold

Tuluksak River

Aniak district

ML 94001681

\section{University of Alaska} (EIR)

910 Yukon Dr., Ste. 211

Fairbanks, AK 99775

Gold

Ist Chance Creek

Fairbanks district

ML 94003831

Usibelli Coal Mine Inc. (EIR)

P.O. Box 1000

Healy, AK 99743

Coal

Poker Flats Mine

Bonnifield district

ML 94005331

Usibelli Coal Mine Inc. (EIR)

P.O. Box 1000

Healy, AK 99743

Coal

Gold Run Pass

Bonnifield district

ML 9400532

Vander Wal, John K. (EIR)

HC 1 Box 3100

Healy, AK 99743

Gold

Walker Creek

Bonnifield district

ML 94006091

Vander Wal, Jon K. (EIR)

HC1 Box 3100

Healy, AK 99743

Gold

Thistle Creek

Bonnifield district

ML 94006301
Vetter, Rudolph (EIR)

P.O. Box 70342

Fairbanks, AK 99707

Gold

Portage and Half Dollar Creeks

Circle district

ML 9400601

Victoria Creek Mine (EIR)

Vincent C. Monzulla

2920 Monzulla Lane

Fairbanks, AK 99712

Gold

Victoria Creek

Fairbanks district

ML 9400625

Vogt, Ray A. (EIR)

2108 Central Ave.

Fairbanks, AK 99701

Gold

Dome Creek

Livengood-Tolovana district

ML 94000531

Voytilla, Earl W. (EIR)

P.O. Box 58211

Fairbanks, AK 99711

Gold

Tenderfoot Creek

Richardson district

ML 94002361

Wade Reese Mining (SCR)

Wade Reese

P.O. Box 141086

Anchorage, AK 99514

Gold

Squaw Creek

Willow Creek district

ML 94006021

Wales Native Corporation (WR)

P.O. Box 529

Wales, AK 99783

Sand \& gravel

East Village Creek

Cape Nome district

ML 94002481

Wales Native Corporation (WR)

P.O. Box 529

Wales, AK 99783

Sand \& gravel

NE Village Creek

Cape Nome district

ML 94002472

Walsh, Daniel P. (WR)

4600 Mars Dr.

Anchorage, AK 99507

Gold

Dexter Creek

Nome district

ML 94002591
Walton Mining (EIR)

1247 Hartzog Loop

North Pole, AK 99705

Gold

Dome Creek

Fairbanks district

ML 94005521

Warhus, Thomas P. (SCR)

P.O. Box 763

Cooper Landing, AK 99572

Gold

Dry Creek

Seward district

ML 94005561

Watkins, Jim (SCR)

P.O. Box 697

Palmer, AK 99645

Gold

N/A

Yentna-Cache Creek district

ML 94006261

Weathers, Douglas \& Edith (SCR)

P.O. Box 8082

Nikiski, AK 99635

Gold

Cache Creek

Yentna-Cache Creek district ML 94002061

Wells, Lu L. (EIR)

P.O. Box 74393

Fairbanks, AK 99709

Gold

Kokomo Creek

Fairbanks district

ML 94002861

White, Paul/Peede, Patrick (EIR)

2551 Peede Rd.

North Pole, AK 99705

Gold

Newman Creek

Fairbanks district

ML 9400068

Wiggers, Dan A. Sr. (NR)

HC 30 Box 5382

Wasilla, AK 99654

Gold

Hammond River

Koyukuk-Nolan district

ML 94002561

Wilder, Richards (EIR)

117 Elray St.

Fairbanks, AK 99709

Gold

Little Boulder Creek

Hot Springs district

ML 94006031
Williams, Wilbur A. \& Ann J.

(SWR)

1908 W. Hillcrest Dr., \#5

Anchorage, AK 99517

Gold

Granite Creek

Iditarod district

ML 94001661

Willis, Dean L. (EIR)

P.O. Box 30063

Central, AK 99730

Gold

Crooked Creek

Circle district

ML 94000851

Wolff, Gordon (SCR)

618 W. 86th Ct.

Anchorage, AK 99515

Gold

Peters Creek

Yentna-Cache Creek district

ML 94002341

Wright, Richard L. (NR)

3910 Tilleson Way

North Pole, AK 99705

Gold

Magnet Creek

Koyukuk-Nolan district

ML. 94003941

Wright, Robert P. (EIR)

P.O. Box 60783

Fairbanks, AK 99706

Gold

Last Chance Creek

Fairbanks district

ML 9400608 I

Yoder, Brian K. Sr. (NR)

3070 Amber Ave

Fairbanks, AK 99709

Gold

Sheep Creek

Chandalar district

ML 94003732

Young, Michael (EIR)

P.O. Box 70277

Fairbanks, AK 99707

Gold

Murphy Creek

Fairbanks district

ML 94006041

Yukon Placer (EIR)

James Munsell

P.O. Box 81155

Fairbanks, AK 99708

Gold

Little Minook Creek

Rampart district

ML 9400171 


\section{APPENDIX F}

Primary metals production in Alaska, 1880-1994

\begin{tabular}{|c|c|c|c|c|c|c|c|c|c|c|c|c|c|c|c|c|c|c|c|c|}
\hline \multirow[b]{2}{*}{ Year } & \multicolumn{2}{|c|}{ Gold } & \multicolumn{2}{|c|}{ Silver } & \multicolumn{2}{|c|}{$\begin{array}{c}\text { Mercury } \\
\end{array}$} & \multicolumn{2}{|c|}{ Antimony } & \multicolumn{2}{|c|}{ Tin } & \multicolumn{2}{|c|}{ Lead } & \multicolumn{2}{|c|}{ Zinc } & \multicolumn{2}{|c|}{ Platinum } & \multicolumn{2}{|c|}{ Copper } & \multicolumn{2}{|c|}{ Chromium } \\
\hline & (oz) & $(\mathrm{mS})$ & (oz) & $(\mathrm{t} \$)$ & $\left(\right.$ flask $\left.^{b}\right)$ & (tS) & (lb) & (tS) & (b) & (tS) & (tons) & (L\$) & (tons) & (15) & (oz) & (t\$) & (ab) & (mS) & (tons) & (\$\$) \\
\hline $\begin{array}{c}1880- \\
1899\end{array}$ & $1,153,889$ & 23.85 & 496,101 & 329.0 & $\cdots$ & 5 & & & 4 & 2. & 250 & 17.0 & .. & -. & - & -. & & & $\Rightarrow$ & $\cdots$ \\
\hline 1900 & 395,030 & 8.17 & 73,300 & 45.5 & -. & .. & -. & -. & .. & $\cdots$ & 40 & 3.4 & $\cdots$ & $\cdots$ & -. & $\cdots$ & $\cdots$ & $\cdots$ & .. & $\cdots$ \\
\hline $\begin{array}{l}1902 \\
1903\end{array}$ & $\begin{array}{l}400,709 \\
420,069\end{array}$ & $\begin{array}{l}8.28 \\
8.68\end{array}$ & $\begin{array}{r}92,000 \\
143,600\end{array}$ & $\begin{array}{l}48.5 \\
77.8\end{array}$ & $\ddot{*}$ & $\cdots$ & $\ddot{\cdots}$ & $\ddot{.}$ & $\begin{array}{l}30,000 \\
50,000\end{array}$ & $\begin{array}{r}8.0 \\
14.0\end{array}$ & $\begin{array}{l}30 \\
30\end{array}$ & $\begin{array}{l}2.5 \\
2.5\end{array}$ & 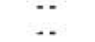 & $\because$ & $\cdots$ & $\ldots$ & $\begin{array}{r}360,000 \\
1,200,000\end{array}$ & $\begin{array}{l}0.04 \\
0.16\end{array}$ & $\therefore$ & $\ddot{.}$ \\
\hline $\begin{array}{l}1903 \\
1904\end{array}$ & 443,115 & 9.16 & 198,700 & 114.9 & -. & .. & .. & .. & 28,000 & 8.0 & 30 & 2.5 & .. & -. & -. & .. & $2,043,586$ & 0.28 & .. & $\ldots$ \\
\hline 1905 & 756,101 & 15.63 & 132,174 & 80.2 & -. & .. & -. & .. & 12,000 & 4.0 & 30 & 2.6 & -. & .. & .. & .. & $4,805,236$ & 0.75 & -- & .. \\
\hline 1906 & $1,066,030$ & 22.04 & 203,500 & 136.4 & $\cdots$ & $\cdots$ & .. & .. & 68,000 & 38.6 & 30 & 3.4 & -. & $\cdot \cdot$ & -. & .. & $5,871,811$ & 1.13 & -. & -. \\
\hline 1907 & 936,043 & 19.35 & 149,784 & 98.8 & .. & .. & .. & -. & 44,000 & 16.8 & 30 & 3.2 & -. & .. & -. & .. & $6,308,786$ & 1.26 & .. & $\cdots$ \\
\hline 1909 & 987,417 & 20.41 & 147,950 & 76.9 & $\cdots$ & $\cdots$ & -. & .. & 22,000 & 7.6 & 69 & 5.9 & $\cdots$ & $\cdots$ & $\cdots$ & $\cdots$ & $4,124,705$ & 0.54 & $\cdots$ & \\
\hline 1910 & 780,131 & 16.13 & 157,850 & 85.2 & -. & .- & - & .. & 20,000 & 8.3 & 75 & 6.6 & 7.- & .. & -. & $\ldots$ & $4,241,689$ & 0.54 & -. & $\cdots$ \\
\hline 1911 & 815,276 & 16.85 & 460,231 & 243.9 & ... & 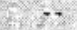 & $\therefore$ & .. & 122,000 & 52.8 & 51 & 4.5 & .. & .. & -. & $\cdots$ & $27,267,778$ & 3.40 & -. & .. \\
\hline 1912 & 829,436 & 17.14 & 515,186 & 316.8 & $\ldots$ & -. & - & -. & 260,000 & 119.6 & 45 & 4.1 & -. & -. & .. & $\ldots$ & $29,230,491$ & 4.82 & $\cdots$ & - \\
\hline 1913 & 755,947 . & 15.63 & 362,563 & 218.9 & -. &.- & $\cdots$ & - & $100,000^{\circ}$ & $44.1^{6}$ & 6 & 0.6 & $\ldots$ & .. & -. & $\ldots$ & $21,659,958$ & 3.35 & .. & $-\cdot$ \\
\hline 1914 & 762,596 & 15.76 & 394,805 & 218.3 & $\cdots$ & .. & -. &.- & 208,000 & 66.6 & 28 & 1.3 & .. & .. & $\ldots$ & .. & $21,450,628$ & 2.85 & .. & $\cdots$ \\
\hline 1915 & 807,966 & 16,70 & $1,071,782$ & 543.3 & -. & $\ldots$ & 520,000 & w & 204,000 & 78.8 & 437. & 41.1 & $\cdots$ & -. & ... & .. & $86,509,312$ & 15.14 & -. & -. \\
\hline 1916 & 834,068 & 17.24 & $1,379,171$ & 907.4 & $\cdots$ & -. & $1,200,000$ & w & 278,000 & 1210 & 820 & 113.2 & $\cdots$ & $\cdots$ & 8 & 0.7 & $119,654,839$ & 29.50 & -. & $\cdots$ \\
\hline 1917 & 709,049 & 14.66 & $1.239,150$ & $1,020.6$ & $\cdots$ & .. & 500,000 & w & 200,000 & 123.3 & 852 & 1466 & $\because$ & $\therefore$ & 53 & 5.5 & $88,793,400$ & 24.40 & 1,100 & w \\
\hline 1918 & 458,641 & 9.48 & 847,789 & 847.8 & $\cdots$ & $\therefore$ & 540,000 & w & 136,000 & 118.0 & 564 & 80.1 & $\ldots$ & .. & 284 & 36.6 & $69,224,951$ & 17.10 & 1,100 & w \\
\hline 1919 & 455,984 & 9.42 & 629,708 & 705.3 & .. & .. & prope. & $\therefore$ & 112,000 & 73.4 & 687 & 72.1 & -. & .. & 569 & 73.7 & $47,220,771$ & 8.80 & -2 & .. \\
\hline 1920 & 404,683 & 8.37 & 953,546 & $1,039.7$ & $\because$ & $\because$ & -. & -. & 32,000 & 16.1 & 875 & 140.0 & .. & -. & 1,478 & 160.1 & $70,435,363$ & 13.00 & -. & -. \\
\hline 1921 & 390,558 & 8.07 & 761,085 & 761.1 & 45 & 1.5 & -. & .. & 8,000 & 2.4 & 759 & 68.3 & $\cdots$ & -. & 40 & 27 & $57,011,597$ & 7.40 & .. & $\cdots$ \\
\hline 1924 & 304,072 & 6.29 & 669,641 & 448.6 & 2 & 0.3 & .. & .. & 14,000 & 7.1 & 631 & 100.9 & .. & .. & 28 & 2.6 & $74,074,207$ & 9.70 & .. & $\cdots$ \\
\hline 1925 & 307,679 & 6.36 & 698,259 & 482.4 & 44 & 3.6 & w & w & 28,600 & 15.4 & 789 & 140.6 & .. & .. & 10 & 1.2 & $73,055,298$ & 10.30 & .. & -. \\
\hline 1926 & 324,450 & 6.70 & 605,190 & 377.0 & 22 & 1.7 & w & w & 16,000 & 10.4 & 778 & 124.4 & .. & $\cdots$ & 3,570 & 274.5 & $67,778,000$ & 9.49 & -. & -. \\
\hline 1927 & 286,720 & 5.97 & 350,430 & 215.0 & $\cdots$ & -. & -. & -. & 53,400 & 34.0 & 1,008 & 127.0 & -. & $\cdots$ & -. & & $55,343,000$ & 7.25 & -. & -. \\
\hline 1928 & 331,140 & 6.85 & 351,730 & 187.0 & .. & .. & .. & .. & 82,000 & 41.0 & 1,019 & 118.0 & .. & .. & 120 & 9.0 & $41,421,000$ & 5.96 & .. & -. \\
\hline 1929 & 375,438 & 7.76 & 472,900 & 252.0 & 4 & 0.5 & .. & .. & 77,200 & 35.0 & 1,315 & 166.0 & .. & .. & 475 & 32.0 & $40,570,000$ & 7.13 & -. & .. \\
\hline 1930 & 408,983 & 8.47 & 408,570 & 157.3 & -- &.- & - & - & 29,400 & 9.3 & 1,365 & 136.5 & -a & - &.- & $\cdots$ & $32,651,000$ & 4.24 & & - \\
\hline 1931 & 459,000 & 9.51 & 352,000 & 102.0 & is & 1.2 & 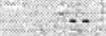 & $\ldots$ & 8.200 & 20 & 1,660 & 126.0 & -2 & $\ldots$ & 393 & 14.0 & $22,614,000$ & 1.88 & $\approx$ & . \\
\hline 1932 & 493,860 & 10.20 & 234,050 & 66.0 & 8 & 0.5 & & $\cdots$ & & .. & 1,260 & 75. & .. & .. & .. & & $8,738,500$ & 0.55 & -2 & ... \\
\hline 1933 & 469,286 & 9.30 & 154,700 & 55.0 & -. & & & -. & 5,800 & 2.3 & 1,157 & 85.6 & -. & -. & 605 & 18.6 & 29,000 & 0.02 & 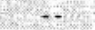 & - \\
\hline 1934 & 537,281 & 8.78 & 154,700 & 100.0 & .. & .. & .. & -. & $8,200^{\circ}$ & 4.3 & 839 & 62.1. & $\ldots$ & .. & 2.555 & 85.6 & 121,000 & 0.06 & -.. & .. \\
\hline 1935 & 469,495 & 16.43 & 286,600 & 206.0 & - & -. & -. & .. & 98,800 & 49.8 & 815 & 65.2 & .. & $\cdots$ & 8.685 & 259.6 & $15,056,000$ & 1.25 & .. & n. \\
\hline 1936 & 540,580 & 18.92 & 484,306 & 375.0 & -. & $\ldots$ & .. & - & 226,000 & 105.0 & 941 & 86.6 & .. & -. & 5,654 & 241.9 & $39,267,000$ & 3.72 & -. & -. \\
\hline 1937 & 627,940 & 21.98 & 494,340 & 382.0 & $\because$ & $\ldots$ & 962,000 & 147.6 & $372,000^{\circ}$ & $202.3^{\circ}$ & 823 & 97.1 & $\cdots$ & $\cdots$ & 9,823 & 313.4 & $36,007,000$ & 4.74 & $\cdots$ & - \\
\hline 1938 & 662,000 & 23.17 & 479,853 & 310.0 & 8 & 0.6 & 444,000 & 54.8 & 210,000 & 89.1 & 994 & 91.5 & .. & $\ldots$ & 41,000 & $2,460.0$ & $29,760,000$ & 2.98 & $\cdots$ & $\ldots$ \\
\hline 1939 & 676,780 & 23.68 & 201,054 & 136.5 & $\therefore$ & & 210,000 & 25.9 & 66,000 & 38.0 & 937 & 88.1 & -. & .. & 33,900 & $2,034.0$ & 278,500 & 0.04 & -. & .. \\
\hline 1940 & 755,900 & 26.45 & 191,679 & 136.3 & $156^{\circ}$ & 130.9 & 306,000 & 42.8 & 92,000 & 52.0 & 840 & 72.0 & .. & .. & 28,886 & $1,093.0$ & 110,000 & 0.02 & .. & .. \\
\hline 1941 & 692,314 & 24.23 & 199,700 & 142.0 & $\mathrm{w}$ & w & 774,000 & 87.3 & $93,600^{\mathrm{c}}$ & $61.0^{\circ}$ & 74 & 58. & .. & .. & 22,630 & 813.0 & 144,000 & 0.0 & -. & -. \\
\hline 1942 & 487,657 & 17.07 & 135,200 & 96.0 & w & w & 316,000 & 41.0 & 5,600 & 2.5 & 523 & 44.0 & -. & .. & 22,000 & 779.0 & 48,000 & 0.01 & .. & .. \\
\hline 1943 & 99,583 & 3.49 & 31,700 & 22.0 & 786 & 153.4 & 368,000 & 33.3 & $2,000^{c}$ & $1.0^{\circ}$ & 200 & 22.0 & .. & .. & 27,900 & $1,020.0$ & 54,000 & 0.01 & 5,564 & 186.3 \\
\hline 1944 & 49,296 & 1.73 & 15,240 & 10.8 & 841 & 165.0 & 70,080 & 30.0 & .. & .. & 44 & 5.8 & -. & .. & 33,616 & $2,017.0$ & 4,000 & 0.01 & 1,845 & 64.6 \\
\hline 1945 & 68,117 & 2.38 & 9,983 & 6.2 & 275 & 180.0 & w & w & .. & .. & 11 & 1.8 & .. & .. & 22,949 & $1,377.0$ & 10,000 & 0.01 & -. & -. \\
\hline 1946 & 226,781 & 7.93 & 41,793 & 26.3 & 699 & 68.7 & w & w & .. & .. & 115 & 25.0 & .. & .. & 22,882 & $1,418.7$ & 4,000 & 0.01 & $\cdots$ & .. \\
\hline 1947 & 279,988 & 9.79 & 66,150 & 46.3 & 127 & 10.6 & 52,000 & 16.1 & 2,000 & 2.2 & 255 & 76.5 & 226 & 0.15 & 13,512 & $1,351.2$ & 24,000 & 0.06 & .. & .. \\
\hline 1948 & 248,395 & 8.69 & 67,341 & 58.7 & 108 & 7.8 & 88,000 & 29.3 & 10,000 & 10.8 & 317 & 88.9 & 226 & 0.15 & 13,741 & $1,209.2$ & 28,000 & 0.07 & .. & -. \\
\hline
\end{tabular}


continued

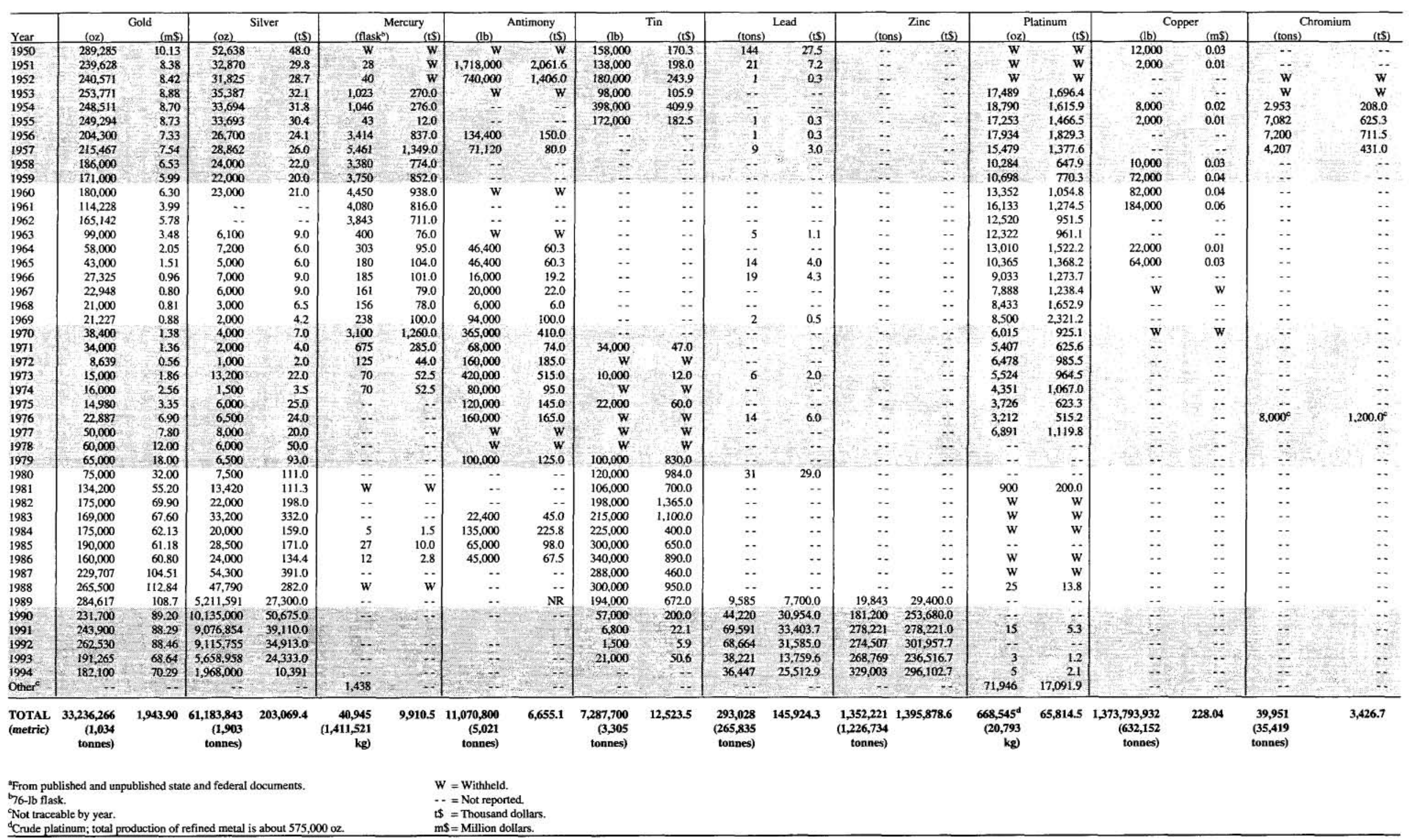




\section{APPENDIX G}

\section{Production of industrial minerals, coal, and other commodities in Alaska, 1880-1994}

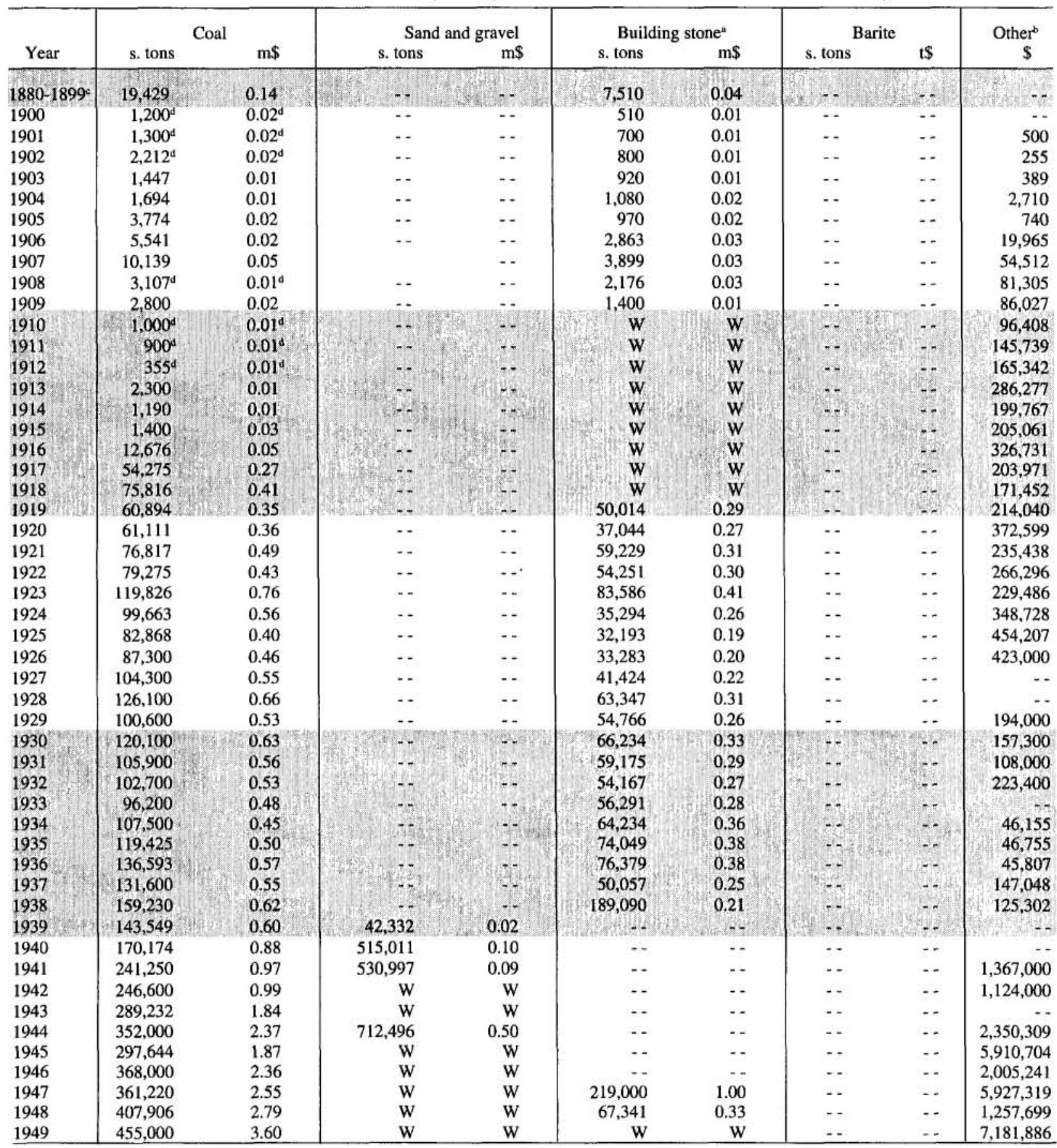

"Building-stone production figures for 1880-1937 are for the southcentral and interior regions of Alaska only.

'Includes 2.4 million $\mathrm{lb} \mathrm{U}_{3} \mathrm{O}_{8}$ (1955-71); 505,000 tons gypsum (1905-26); 286,000 lb WO (intermittently 1916-80); 94,000 lb asbestos (1942-44); $540,000 \mathrm{lb}$ graphite (1917-18; and 1942-50); and undistributed amounts of zinc, jade, peat, clay, soapstone, miscellaneous gemstones, and other commodities (1880-1993).

'Production not traceable by year.

'When state (territorial) and federal figures differ significantly, state figures are used. Figures for sand and gravel production in 1974 show state estimates

$(118,740,000$ s. tons; $240.94 \mathrm{~m} \$)$ and federal $(42,614,000$ s. tons; $88.96 \mathrm{~m} \$)$. The federal estimate was not added to total production. 'Marble quarried on Prince of Wales Island, southeastern Alaska (1900-41).

$\mathrm{m} \$=$ Million dollars.

$\mathrm{t} \$=$ Thousand dollars.

$\ldots=$ Not reported.

$\mathrm{W}=$ Withheld 


\begin{tabular}{|c|c|c|c|c|c|c|c|c|c|}
\hline \multirow[b]{2}{*}{ Year } & \multicolumn{2}{|c|}{ Coal } & \multicolumn{2}{|c|}{ Sand and gravel } & \multicolumn{2}{|c|}{ Building stone } & \multicolumn{2}{|c|}{ Barite } & \multirow{2}{*}{$\begin{array}{l}\text { Other } \\
\$\end{array}$} \\
\hline & s. tons & $\mathrm{m} \$$ & s. tons & $\mathrm{m} \$$ & s. tons & m\$ & s. tons & t\$ & \\
\hline 1950 & 421,455 & 3.03 & $3,050,020$ & 2.38 & W & W & -. & $\because$ & $2,100,000$ \\
\hline 1951 & $494,333^{\circ}$ & 3.77 & $6,818,000$ & 3,54 & W & W & .8 & -. & $3,600,000$ \\
\hline 1952 & 648,000 & 5.77 & $6,817,800$ & 3.54 & W & W & -- &.- & $9,052,000$ \\
\hline 1953 & 861,471 & 8.45 & $7,689,014$ & 5.08 & 47,086 & 0.17 & .. & - & $1,231,350$ \\
\hline 1954 & 666,618 & 6.44 & $6,639,638$ & 6.30 & 283,734 & 0.47 &.- & - & $1,572,150$ \\
\hline 1955 & 639,696 & 5.76 & $9,739,214$ & 8.24 & 265,740 & 0.29 & -2 & .. & $1,552,427$ \\
\hline 1956 & 697,730 & 6.37 & $9,100,000$ & 8.30 & 50,000 & 0.02 & -1 & -2 & $1,551,500$ \\
\hline 1957 & 842,338 & 7.30 & $6,096,000$ & 8.79 & 528,000 & 1.95 & $\rightarrow$ & $\ldots$ & $2,751,000$ \\
\hline 1958 & 759,000 & 6.93 & $4,255,000$ & 3.87 & 615,000 & 2.07 & $\ldots$ & H. & 695,000 \\
\hline 1959 & $602,000^{d}$ & $5,88^{\mathrm{d}}$ & $5,600,000$ & 5.10 & 54,000 & 0.20 & ... & -. & $1,338,000$ \\
\hline 1960 & $669,000^{d}$ & $5.95^{\mathrm{d}}$ & $5,892,000$ & 5.35 & 80,000 & 0.30 & - & -. & 975,000 \\
\hline 1961 & $650,000^{d}$ & $5.87^{\circ}$ & $5,241,000$ & 4.19 & - & - & -. & -- & - \\
\hline 1962 & $675,000^{d}$ & $6.41^{\mathrm{d}}$ & $5,731,000$ & 5.36 & -. & -- & - & -. & $\ldots$ \\
\hline 1963 & 853,000 & 5.91 & $16,926,000$ & 22.01 & w & W & W & W & $2,589,000$ \\
\hline 1964 & 745,000 & 5.01 & $26,089,000$ & 18.49 & W & W & W & W & $4,912,000$ \\
\hline 1965 & $860,000^{d}$ & $5.88^{\mathrm{d}}$ & $29,959,000$ & 33.93 & W & W & W & W & $5,296,000$ \\
\hline 1966 & 927,000 & 6.95 & $17,457,000$ & 21.79 & W & W & 44,000 & 350.0 & $6,167,000$ \\
\hline 1967 & 930,000 & 7.18 & $22,300,000$ & 26.25 & W & W & W & W & $4,924,000$ \\
\hline 1968 & $812,000^{d}$ & $5.03^{d}$ & $17,515,000$ & 20.73 & W & W & 91,000 & W & $4,117,000$ \\
\hline 1969 & $728,000^{d}$ & $4.65^{d}$ & $16,205,000$ & 18.62 & $1,954,000$ & 3.90 & 90,000 & 850.0 & $5,163,000$ \\
\hline 1970 & $786,000^{\mathrm{d}}$ & $5.28^{\mathrm{d}}$ & 20,$375 ; 000^{d}$ & $26.07^{d}$ & $6,470,000$ & 10.01 & $134,000^{d}$ & $1,875.0$ & $7,994,000$ \\
\hline 1971 & $748,000^{d}$ & $5.05^{\mathrm{d}}$ & $26,391,000$ & 41.99 & $2,658,000$ & 5.07 & $102,000^{\mathrm{d}}$ & $1,075.0$ & $4=-7$ \\
\hline 1972 & $720,000^{\circ}$ & $6.26^{\mathrm{d}}$ & $14,187,000$ & 15.21 & 652,000 & 3.01 & W & W & 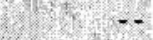 \\
\hline 1973 & $700,000^{d}$ & $6.23^{d}$ & $19,350,000$ & 19.01 & $5,967,000$ & 12.00 & 112,000 & $1,792.0$ & $12,846,000$ \\
\hline \multirow[t]{2}{*}{1974} & 700,000 & 7.34 & $118,740,000^{\mathrm{d}}$ & $240.94^{4}$ & $5,484,000$ & 12.95 & 110,000 & $1,895.0$ & $14,495,000$ \\
\hline & & & $42,614,000$ & 88.96 & & & & & \\
\hline 1975 & 766,000 & 7.81 & $48,145,000$ & 95.78 & $8,877,000$ & 26.65 & $2,000^{f}$ & 30.0 & $12,731,000$ \\
\hline 1976 & 705,000 & 8.00 & $74,208,000^{d}$ & $204.73^{\mathrm{d}}$ & $6,727,000$ & 20.09 & W & W & $14,019,000$ \\
\hline 1977 & $780,000^{d}$ & $12.00^{\delta}$ & $66,126,000$ & 134.25 & $4,008,000$ & 17.47 &.- & 1. & $14,486,000$ \\
\hline 1978 & 750,000 & 15.00 & $51,100,000$ & 122.00 & $3,437,000$ & 14.65 & 22,000 & 750.0 & (2) $0=0$ \\
\hline 1979 & 750,000 & 16.00 & $50,900,000$ & 104.90 & $3,650,000$ & 15.45 & 20,000 & 800.0 & 930,000 \\
\hline 1980 & 800,000 & 16.00 & $40,000,000$ & 86.00 & $3,700,000$ & 15.40 & 50,000 & $2,000.0$ & 97,500 \\
\hline 1981 & 800,000 & 17.60 & $46,000,000$ & 88.20 & $4,200,000$ & 19.30 & . & - & 256,000 \\
\hline 1982 & 830,000 & 18.00 & $45,000,000$ & 91.00 & $3,400,000$ & 15.60 & $\cdots$ & -- & 150,000 \\
\hline 1983 & 830,000 & 18.00 & $50,000,000$ & 105.00 & $5,270,000$ & 25.00 & -- & -. & 242,000 \\
\hline 1984 & 849,161 & 23.75 & $27,000,000$ & 95.00 & $2,700,000$ & 16.00 & - & - & 875,875 \\
\hline 1985 & $1,370,000$ & 39.73 & $28,184,080$ & 112.06 & $2,500,000$ & 12.00 & - & -. & 559,000 \\
\hline 1986 & $1,492,707$ & 40.10 & $20,873,110$ & 75.76 & $4,200,000$ & 20.32 & $\cdots$ & $-\cdot$ & 384,800 \\
\hline 1987 & $1,508,927$ & 42.35 & $16,696,374$ & 42.66 & $1,805,000$ & 11.62 & - & - & 388,400 \\
\hline 1988 & $1,551,162$ & 44.30 & $17,264,500$ & 48.75 & $3,600,000$ & 24.65 & $-\cdot$ & -- & 389,000 \\
\hline 1989 & $1,452,353$ & 41.46 & $14,418,000$ & 39.88 & $2,914,000$ & 20.34 & $\cdots$ & $\cdots$ & $1,492,000$ \\
\hline 1990 & $1,576,000$ & 44.99 & $15,013,500$ & 40.82 & $3,200,000$ & 22.10 & - & $\ldots$ & 400,000 \\
\hline 1991 & $1,540,000$ & 39.00 & $14,160,011$ & 45.45 & $3,000,000$ & 22.50 & 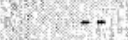 & $\cdots$ & 462,000 \\
\hline 1992 & $1,531,800$ & 38.30 & $14,599,746$ & 42.20 & $2,900,000$ & 22.97 & $\ldots$ & $\cdots$ & 430,000 \\
\hline 1993 & $1,586,545$ & 38.10 & $13,162,402$ & 40.64 & $3,561,324$ & 26.21 & -- & $\cdots$ & 465,000 \\
\hline 1994 & $1,490,000$ & 36.75 & $13,518,321$ & 40.95 & $3,843,953$ & 27.04 & $\ldots$ & 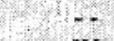 & 459,500 \\
\hline Other & 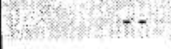 & -4 & 10 & $\ldots$ & $2,300,000^{\circ}$ & W & 79,000 & W & .. \\
\hline $\begin{array}{l}\text { TOTAL } \\
\text { (metric) }\end{array}$ & $\begin{array}{r}46,708,428 \\
(42,373,885 \\
\text { tonnes) } \\
\end{array}$ & 738.35 & $\begin{array}{r}1,096,332,564 \\
(994,592,902 \\
\text { tonnes) } \\
\end{array}$ & $2,231.8$ & $\begin{array}{r}106,445,113 \\
(96,567,007 \\
\text { tonnes }) \\
\end{array}$ & 454.10 & $\begin{array}{r}856,000 \\
(776,563 \\
\text { tonnes) } \\
\end{array}$ & $11,417.0$ & $176,947,372$ \\
\hline
\end{tabular}




\begin{tabular}{|c|c|c|}
\hline \multicolumn{3}{|c|}{ U.S. Customary Units/Metric Units Conversion Chart } \\
\hline To convert from: & To: & Multiply by: \\
\hline \multicolumn{3}{|c|}{ Weight/Mass } \\
\hline $\begin{array}{l}\text { ounces (avoirdupois) } \\
\text { ounces (troy) } \\
\text { pounds } \\
\text { short tons } \\
\text { grams } \\
\text { kilograms } \\
\text { metric tons }\end{array}$ & $\begin{array}{l}\text { grams } \\
\text { grams } \\
\text { kilograms } \\
\text { metric tons } \\
\text { ounces (avoirdupois) } \\
\text { ounces (troy) } \\
\text { pounds } \\
\text { short tons }\end{array}$ & $\begin{array}{l}28.350 \\
31.1035 \\
0.4536 \\
0.9072 \\
0.03527 \\
0.03215 \\
2.2046 \\
1.1023\end{array}$ \\
\hline \multicolumn{3}{|c|}{ Length } \\
\hline $\begin{array}{l}\text { inches } \\
\text { kilometers } \\
\text { meters } \\
\text { millimeters } \\
\text { centimeters }\end{array}$ & $\begin{array}{l}\text { kilometers } \\
\text { meters } \\
\text { meters } \\
\text { millimeters } \\
\text { centimeters } \\
\text { millimeters } \\
\text { centimeters } \\
\text { miles } \\
\text { yards } \\
\text { feet } \\
\text { feet } \\
\text { inches } \\
\text { inches }\end{array}$ & $\begin{array}{l}1.6093 \\
0.9144 \\
0.3048 \\
3.048 \\
30.48 \\
25.4 \\
2.54 \\
0.6214 \\
1.0936 \\
3.2808 \\
0.03937 \\
0.3937 \\
3.937\end{array}$ \\
\hline \multicolumn{3}{|c|}{ Area } \\
\hline $\begin{array}{l}\text { square miles } \\
\text { acres } \\
\text { square yards } \\
\text { square feet } \\
\text { square inches } \\
\text { square kilometers } \\
\text { square meters } \\
\text { hectares } \\
\text { square centimeters } \\
\text { square millimeters }\end{array}$ & $\begin{array}{l}\text { square kilometers } \\
\text { square meters } \\
\text { hectares } \\
\text { square meters } \\
\text { square meters } \\
\text { square centimeters } \\
\text { square millimeters } \\
\text { square miles } \\
\text { acres } \\
\text { square feet } \\
\text { square yards } \\
\text { acres } \\
\text { square meters } \\
\text { square inches } \\
\text { square inches }\end{array}$ & $\begin{array}{c}2.590 \\
4,046.873 \\
0.4047 \\
0.8361 \\
0.0929 \\
6.4516 \\
645.16 \\
0.3861 \\
0.000247 \\
10.764 \\
1.196 \\
2.471 \\
10,000.00 \\
0.155 \\
0.00155\end{array}$ \\
\hline \multicolumn{3}{|c|}{ Volume } \\
\hline $\begin{array}{l}\text { cubic yards } \\
\text { cubic feet } \\
\text { cubic inches } \\
\text { cubic meters } \\
\text { cubic centimeters } \\
\text { gallons (U.S.) } \\
\text { liters } \\
\text { milliliters } \\
\text { ounces (fluid) }\end{array}$ & $\begin{array}{l}\text { cubic meters } \\
\text { cubic meters } \\
\text { cubic centimeter } \\
\text { cubic yards } \\
\text { cubic feet } \\
\text { cubic inches } \\
\text { liters } \\
\text { gallons (U.S.) } \\
\text { ounces (fluid) } \\
\text { milliliters }\end{array}$ & $\begin{array}{c}0.7646 \\
0.02832 \\
16.3871 \\
1.3079 \\
35.3145 \\
0.06102 \\
3.7854 \\
0.2642 \\
0.03381 \\
29.5735\end{array}$ \\
\hline \multicolumn{3}{|c|}{$\begin{array}{l}\text { Temperature conversions: } \\
\text { From degrees Fahrenheit to degrees Celsius, subtract } 32 \text { and multiply by } 5 / 9 \text {. } \\
\text { From degrees Celsius to degrees Fahrenheit, multiply by } 9 / 5 \text { and add } 32 \text {. }\end{array}$} \\
\hline
\end{tabular}


NOTES 
NOTES 


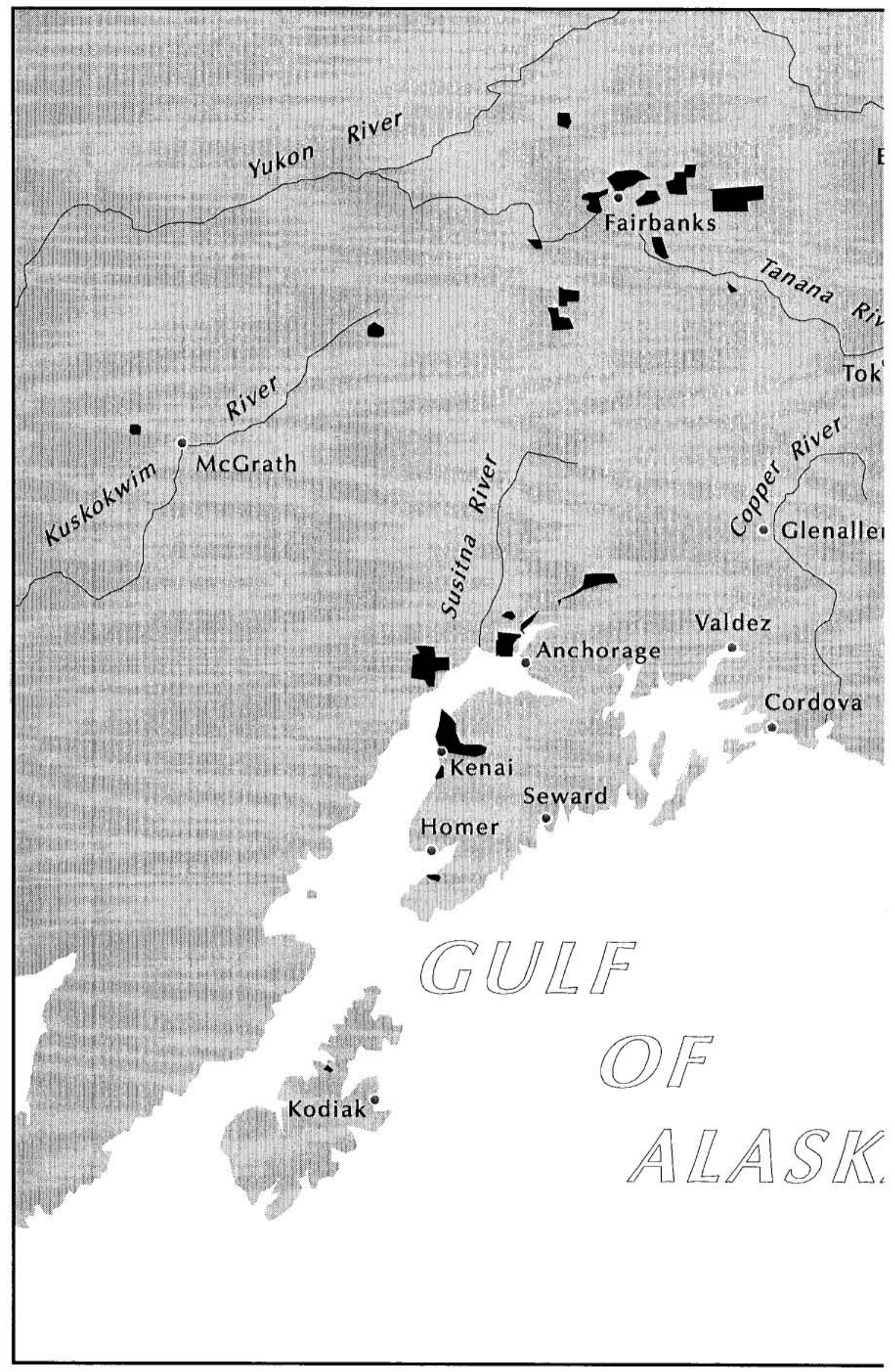


Generalized locations of Alaska Mental Health Trust Land. See report referenced below for details of April 28, 1994, and September 28, 1994 revisions

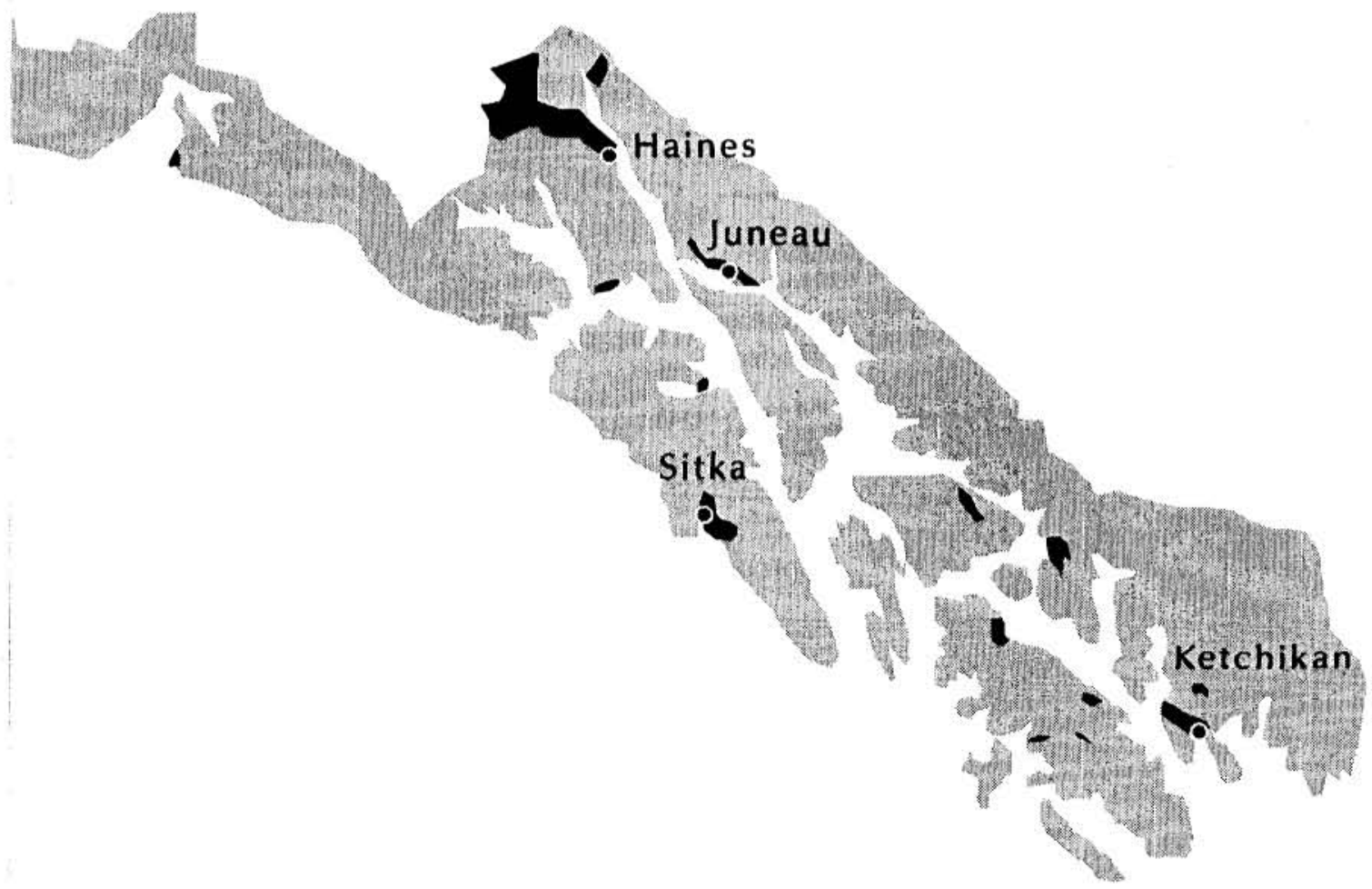

RCE: Alaska Department of Natural Resources, 1994 Reconstitution of the Mental Health Trust and Confirmation and Ratification of Conversion of Certain Original Mental Health Land to General Grant Land: Department of Natural Resource statewide index map, scale 1:4,608,000. Detailed maps (USGS 1:63,360 quadrangles) showing parcel boundaries are available for review at the Department of Natural Resources Public Information Centers in Anchorage, Juneau, and Fairbanks. 


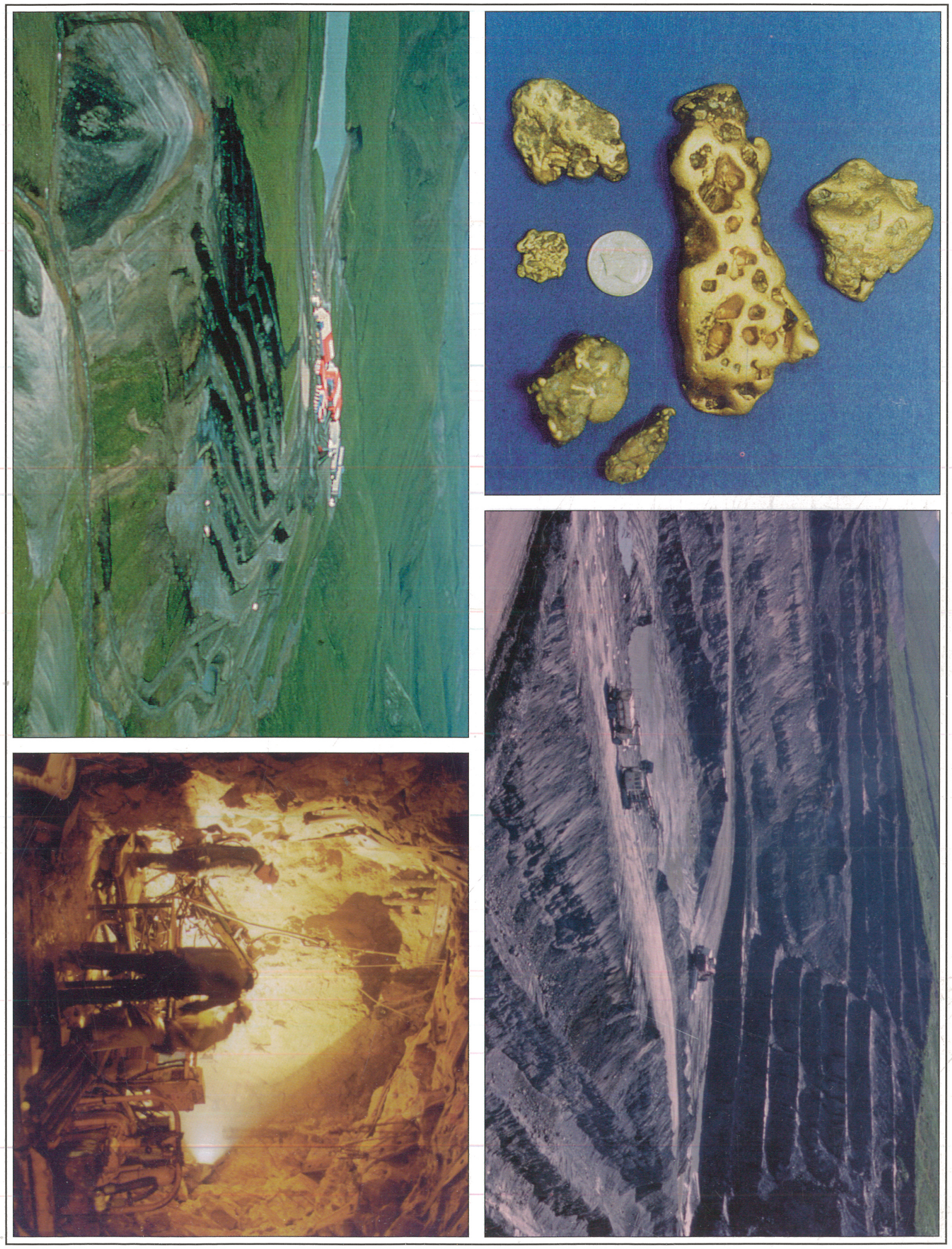

